\title{
IntechOpen
}

\section{Biological Diversity and Sustainable Resources Use}

Edited by Oscar Grillo and Gianfranco Venora 



\section{BIOLOGICAL DIVERSITY AND SUSTAINABLE RESOURCES USE}

Edited by Oscar Grillo and Gianfranco Venora 


\section{Biological Diversity and Sustainable Resources Use}

http://dx.doi.org/10.5772/1834

Edited by Oscar Grillo and Gianfranco Venora

\section{Contributors}

Andre Johannes Pelser, Nola Redelinghuys, Nontombi Velelo, Maria G.L. Brandão, Cristiane Grael, Christopher William Fagg, Giselle Zenker Justo, Carmen Ferreira, Ana Carolina Souza, Hugo Rocha, Matheus Freitas Fernandes-Pedrosa, Angelo De Fatima, Joseph Hitimana, James Legilisho Ole Kiyiapi, Humphrey Kisioh, Fiesta Warinwa, Rose Mayienda, Daudi Sumba, Philip Lenaiyasa, Pauline Wambui Kibugi, Ingrid Schuler, Luis Antonio Orozco, Elizabeth Hodson, Cecilia Peluola

\section{(c) The Editor(s) and the Author(s) 2011}

The moral rights of the and the author(s) have been asserted.

All rights to the book as a whole are reserved by INTECH. The book as a whole (compilation) cannot be reproduced, distributed or used for commercial or non-commercial purposes without INTECH's written permission.

Enquiries concerning the use of the book should be directed to INTECH rights and permissions department (permissions@intechopen.com).

Violations are liable to prosecution under the governing Copyright Law.

\section{(c) BY}

Individual chapters of this publication are distributed under the terms of the Creative Commons Attribution 3.0 Unported License which permits commercial use, distribution and reproduction of the individual chapters, provided the original author(s) and source publication are appropriately acknowledged. If so indicated, certain images may not be included under the Creative Commons license. In such cases users will need to obtain permission from the license holder to reproduce the material. More details and guidelines concerning content reuse and adaptation can be foundat http://www.intechopen.com/copyright-policy.html.

\section{Notice}

Statements and opinions expressed in the chapters are these of the individual contributors and not necessarily those of the editors or publisher. No responsibility is accepted for the accuracy of information contained in the published chapters. The publisher assumes no responsibility for any damage or injury to persons or property arising out of the use of any materials, instructions, methods or ideas contained in the book.

First published in Croatia, 2011 by INTECH d.o.o.

eBook (PDF) Published by IN TECH d.o.o.

Place and year of publication of eBook (PDF): Rijeka, 2019.

IntechOpen is the global imprint of IN TECH d.o.o.

Printed in Croatia

Legal deposit, Croatia: National and University Library in Zagreb

Additional hard and PDF copies can be obtained from orders@intechopen.com

Biological Diversity and Sustainable Resources Use

Edited by Oscar Grillo and Gianfranco Venora

p. cm.

ISBN 978-953-307-706-2

eBook (PDF) ISBN 978-953-51-5187-6 


\section{We are IntechOpen, \\ the world's leading publisher of Open Access books}

Built by scientists, for scientists

\section{$4,100+$}

Open access books available

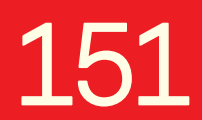

Countries delivered to
$116,000+$

International authors and editors
$120 \mathrm{M}+$

Downloads

Our authors are among the

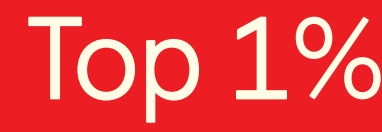

most cited scientists

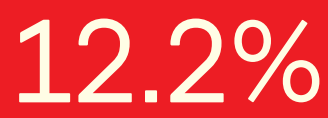

Contributors from top 500 universities

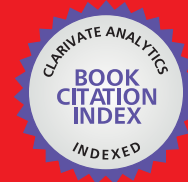

WEB OF SCIENCE ${ }^{\mathrm{TM}}$

Selection of our books indexed in the Book Citation Index in Web of Science ${ }^{\mathrm{TM}}$ Core Collection (BKCI)

Interested in publishing with us?

Contact book.department@intechopen.com

Numbers displayed above are based on latest data collected.

For more information visit www.intechopen.com

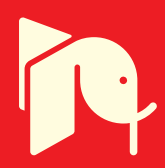





\section{Meet the editors}

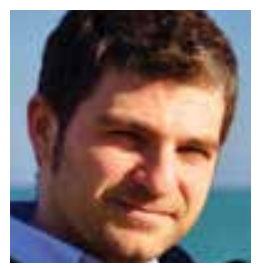

Dr. Oscar Grillo was born in Catania (Sicily) in 1977, he is a food technologist with an international $\mathrm{PhD}$ in applied and environmental botany. Since 2003 he has been working as researcher at the Stazione Sperimentale di Granicoltura per la Sicilia, a governmental institute of agronomic research, mainly working with computer vision applied to food matrices and plant structures, above all seeds, and in particular studying wheat and the related leguminous. Currently, he is working also at the Sardinian Germplasm Bank of the Biodiversity Conservation Centre of the University of Cagliari on projects devoted to seed characterization and identification by image analysis. Results of his work have been published in many peer-reviewed journals papers and international conference papers. Referee for a few peer-reviewed journals, many times he has been invited as teacher/lecturer/speaker by some universities and research centres in Spain and Italy. He has trained many MSc and PhD students, who have made their own contributions to the agronomical and botanical research.

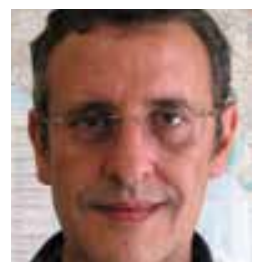

Dr. Gianfranco Venora is a biologist, born in Caltagirone (Sicily) in 1958, where he lives and works. He took his University degree in 1981, and since 1982 he has been working as researcher at the Stazione Sperimentale di Granicoltura per la Sicilia. His working expertise is mainly about durum wheat and leguminous breeding. At the beginning of 1990, after some years of experience on karyotyping cropped and wild species of agronomical importance, he was fascinated by computer vision applied to food matrices and plant anatomical structures, studying wheat and the related leguminous. He was recently nominated as professor to the research doctorate on Applied and Environmental Botany of the University of Cagliari. Many peer-reviewed journals published his papers and he was invited as speaker in many international conferences, and as teacher/lecturer by some universities and research centres in Germany, Netherlands, Bulgaria, Spain, Czech Republic and Italy. Gianfranco Venora is currently referee for about 15 peer-reviewed journals and tutor of many MSc and PhD students. 



\section{Contents}

\section{Preface XI}

Chapter 1 Challenges of Linking Socio-Economic

Significance and Conservation Value of Forests in Drylands of Kenya: Case Study of Kirisia Forest-Samburu Pastoralists Coexistence 1 Joseph Hitimana, James Legilisho Ole Kiyiapi, Pauline Wambui Kibugi, Hamphrey Kisioh, Rose Mayienda, Fiesta Warinwa, Philip Lenaiyasa and Daudi Sumba

Chapter 2 People, Parks and Poverty: Integrated Conservation and Development Initiatives in the Free State Province of South Africa $\mathbf{3 5}$ André Pelser, Nola Redelinghuys and Nontombi Velelo

Chapter 3 Biodiversity, Ecology and Toxic Principles in Plants

- Case Study: Fungal Biocontrol 63

Cecilia Peluola

Chapter 4 The Potential of Biodiversity in the Andean Region: Use, Conservation and Regulations 77

Ingrid Schuler G., Elizabeth Hodson de Jaramillo and Luis Antonio Orozco C.

Chapter 5 European Naturalists and Medicinal Plants of Brazil 101 Maria G. L. Brandão, Cristiane F. F. Grael and Christopher W. Fagg

Chapter 6 The Medicinal Value of Biodiversity: New Hits to Fight Cancer 121 Giselle Z. Justo, Ana C. S. Souza, Ângelo de Fátima, Matheus F. F. Pedrosa, Carmen V. Ferreira and Hugo A. O. Rocha 



\section{Preface}

The maintenance of the stability between ecosystems and biological diversities plays a crucial role in the achievement of goals linked to environmental, economical and social improvement at a global level. This process, that could be defined as "sustainable development", connects the environmental protection with the increasing value of the natural resources, in order to satisfy the needs of contemporary generations. In this sense, the developmental sustainability results to be inconsistent with the natural resources degradation.

In the last years, driven by the increasing necessity to preserve the ecosystem productivity, several ecological and economical studies have been conducted, highlighting the current condition in which our planet is, and outlining the future perspectives.

Biological Diversity and Sustainable Resources Use includes interesting overviews and original case studies, mainly focused on socio-economical effects of the right management of the ecosystems biodiversity, as well as on the useful integration between human activities and environmental response.

Oscar Grillo

Stazione Sperimentale di Granicoltura per la Sicilia, Caltagirone

Biodiversity Conservation Centre, University of Cagliari

Gianfranco Venora

Stazione Sperimentale di Granicoltura per la Sicilia, Caltagirone, Italy 



\title{
Challenges of Linking Socio-Economic Significance and Conservation Value of Forests in Drylands of Kenya: Case Study of Kirisia Forest-Samburu Pastoralists Coexistence
}

\author{
Joseph Hitimana ${ }^{1}$ et al. ${ }^{*}$ \\ ${ }^{1}$ Kabianga University College, Kabianga \\ Kenya
}

\section{Introduction}

According to IUCN, UNEP and WWF, sustainability encompasses improving the quality of human life within the carrying capacity of supporting eco-systems (Figure 1).

Rural communities around the Kirisia forest are mainly pastoralists whose livelihoods highly depend on livestock dominated by cattle. The forest is an important source of browse, grazing land and water particularly during drought. Forests as natural resources are associated with economic value, aesthetic value, legal value and ethical value. People have the moral duty to protect and conserve the resources for future generations. On the productive front, a natural resource value rests in the amount and extractability of the material available and the demand for it.

The Kirisia Forest Reserve is a critical habitat for a rich wildlife and supports the livelihoods of adjacent communities to an extent that is not exhaustively documented. Both the wildlife and people can inflict negative impacts on the ecosystem if they are not checked and controlled. At the moment, most of the human activities within the Kirisia forest, as in all the natural forests in Kenya, are not planned, controlled nor coordinated. There is lack of management plans, scanty research findings and poor documentation of indigenous knowledge which all together are fundamental prerequisite to the sustainable management and conservation of natural forests. No forest management option can be sustainable unless the interests and needs of people and other living components linked to or dependent on the ecosystem are integrated into a management plan (Odhiambo, 2005). According to Eckersley (1992), conservation should be based on three principles: (i) the development of natural

\footnotetext{
* James Legilisho Ole Kiyiapi², Pauline Wambui Kibugi ${ }^{3}$, Hamphrey Kisioh", Rose Mayienda ${ }^{5}$, Fiesta Warinwa ${ }^{5}$, Philip Lenaiyasa ${ }^{5}$ and Daudi Sumba ${ }^{5}$

${ }^{2}$ Ministry of Education, Nairobi, Kenya

${ }^{3}$ Chepkoilel University College, Eldoret, Kenya

${ }^{4}$ REAPS-Consult Ltd, Nairobi, Kenya

${ }^{5}$ African Wildlife Foundation, Nairobi, Kenya
} 


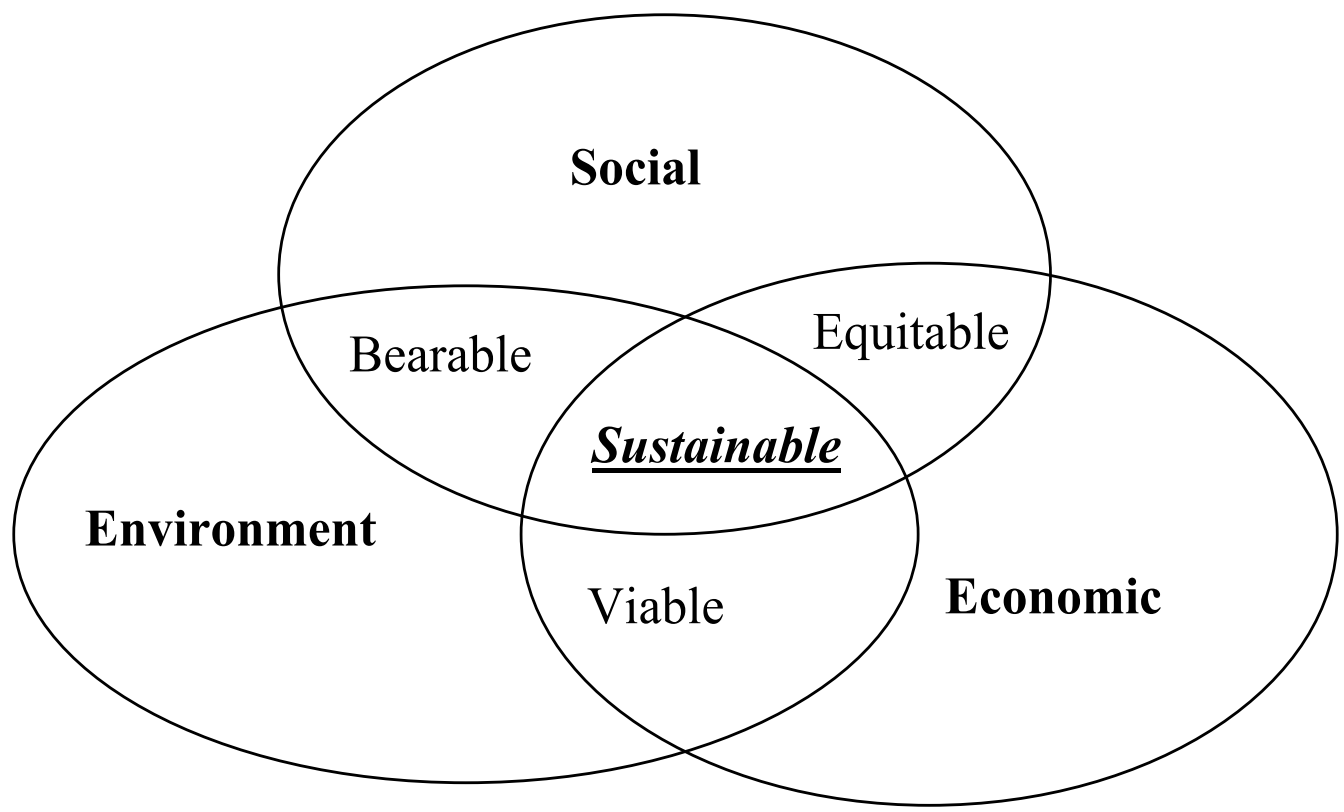

Fig. 1. Scheme of sustainable development of resources (economically viable and equitable; environmentally viable and bearable; and socially bearable and equitable).

resources under scientific management, (ii) reduction of waste and (iii) equity in access to resources based on the ideals of human welfare ecology which also emphasizes environmental quality and social issues such as recreation, spiritual and psychological needs (ecosystem management concept). The level of disturbance to the Kirisia forest ecosystem through human activities and other uses was (before this study) not known and there had been no measure of the actual socio-economic value of the Kirisia forest to its immediate users, which are local adjacent communities. Local communities must be empowered in knowledge, structures and technologies to ensure sustainable utilization of communitybased natural resources for improved livelihoods, environmental protection and sustainable development. Realizing that the capacity of the Government alone to conserve the Kirisia forest is limited, African Wildlife Foundation (AWF) initiated the process of informationgathering about the ecosystem by commissioning scientific studies in order to use findings to enlighten members of adjacent Group Ranches and motivate them to support participatory forest management initiatives and avoid over-reliance on the forest resources. AWF is known to support pastoral communities in wildlife-rich landscapes to adopt integrated land use models that are developmental and conservation-friendly. The AWF mission is to work with the people of Africa and AWF supporters to conserve the wildlife and wildlands of Africa. Improving livelihood of people in regions where AWF operates and to support wildlife conservation initiatives both within and outside protected areas are some of AWF's key objectives under its landscape conservation program branded: "the African Heartlands Program". Many studies commissioned by AWF about Kirisia forest ecosystem include forest assessment which emphasised different forest uses in blocks bordering two Group Ranches, Baawa and Lpartuk (Watai and Gachathi, 2003). In these blocks, the following tasks were undertaken: a general inventory of common plant species, identifying commonly used nontimber forest products and main threats to key species, and exploring opportunities for low- 
impact eco-tourism and other sustainable economic activities. The survey was conducted using various participatory methods including: group discussions, transect walks/drives, demonstrations, observations and excursions to selected areas. Ecologically, it was of low intensity but generated useful information. The study revealed that Kirisia forest is of considerable ecological, social and economic importance to the surrounding communities. In addition to its role as a water catchment, the forest is the source of dry season fodder, medicine for people and livestock, firewood, building poles, fruits, edible roots and tubers, vegetables, oils, dyes, fibres, honey and various items of culture among others. Most plants have clearly defined place in the life of the people either through material value, ceremonial or ritual meaning. A total of 96 plant species in 42 families were identified. These are put into various uses (Watai and Gachathi, 2003). Another study dealt with assessment of bee-keeping potential in the area (MKK, 2005). This study was carried out in six Group Ranches to establish a baseline for future monitoring of the impact of a refinery on bee keeping, income generation and forest conditions. Beekeepers' perception of the condition of the forest, their willingness to put their hives in the forest, other forest uses and expenditure patterns were also investigated. AWF also has supported the development of tourism strategy for Samburu District in 2007 which proposed tourism development initiatives in several Group Ranches including those around Kirisia forest (Ikua \& Sommerlatte, 2007). Finally, in 2005, AWF commissioned a more comprehensive and integrated study simultaneously combining both ecological and socioeconomic aspects. An intensive participatory ecological survey was undertaken to characterize the Kirisia Forest Reserve as a whole (Hitimana et al., 2009) and a socioeconomic survey within adjacent Group Ranches was also carried out by use of questionnaires. This paper is a consolidation of socio-economic aspects from both studies with a clear linkage between conservation and improving people's livelihoods. That is, the paper focuses on socioeconomic profile of the forest adjacent communities, dependence on forest and forest resources, and impact of this dependence on the integrity of Kirisia forest ecosystem.

\subsection{Study context and objectives}

Adjacent communities continuously define ways of utilizing forest resources in order to meet their basic livelihood needs, which means that roles and values of forests to the local communities are also dynamic in space and time (Warner, 1997). In the Kirisia Forest context, the abundant wildlife and high level dependence of Samburu people on the forest may reduce the carrying capacity of the ecosystem leading to its degradation if no adequate management measures are put in place. So far the Government protects the forest through State employed personnel (forester and forest guards). This system has registered overwhelming failure across the nation which has led the Government to review its strategy under the Forests Act 2005 (GoK, 2005). The current forests law encourages local communities and other stakeholders to participate actively in forest management and conservation jointly with the Government agencies through signed agreements that guarantee, among others, greater and easy access and meaningful sharing of benefits accruing from the well managed resources (Gow, 1992). As prerequisite to such joint agreements, the resource base itself must be known and understood in terms of functions and renewability. It is against the above background that AWF sponsored in-depth participatory ecological and socioeconomic surveys in view to better understand challenges facing this ecosystem's integrity and its role in supporting livelihoods of adjacent communities. Data collection instruments used in this study were designed to capture the above variables with reference to ecological state of Kirisia Forest Reserve. 
Participatory forest management is legally entrenched in the Kenya Forests Act 2005. It involves all stakeholders, particularly the government and organized local communities in the sustainable conservation of the resources with some arrangements on benefits-sharing as authorized under the provisions of the Forests Act 2005, Section IV. Local communities must organize themselves into Community Forest Associations (CFAs). The user rights of the forest by the registered CFAs include extraction of non-wood products, ecotourism and recreational activities and development of community wood and non-wood forest based industries provided that none of the activities conflicts with the conservation of biodiversity (Article 47). Along side a participatory forest management plan as a prerequisite to this form of forest resource governance, empowerment of the local community is also critical.

Objectives of the socioeconomic investigations around the Kirisia Forest Reserve were to: (i) identify the nature and magnitude potential of socio-economic and cultural benefits from the forest; (ii) identify and analyze forest-resource-based conflicts; (iii) package socioecological information to inform the development of a sustainable forest-based resource management and conservation model. Research questions were about the actual and potential use of forest by local communities for: (i) timber and other products commonly extracted from the forest; (ii) bee-keeping; (iii) medicinal plants; (iv) eco-tourism; (v) cultural and religious activities; and (vi) negative impacts of the forest on people and how to mitigate them.

Integrating findings from ecological and socioeconomic investigations provides meaningful insights about the landscape management model to be adopted in order to improve people's livelihoods while conserving natural resources within and outside the Kirisia Forest Reserve; through supporting participatory forest management planning and promoting community-based natural resource management planning in Group Ranches around the Kirisia Forest Reserve.

\section{Materials and methods}

\subsection{Description of the study area}

The Kirisia forest is in Samburu District, Rift-Valley Province, Kenya. Samburu District, between $0^{\circ} 40^{\prime} \mathrm{N}-2^{\circ} 50^{\prime} \mathrm{N}$ and $36^{\circ} 20^{\prime} \mathrm{E}-38^{\circ} 10^{\prime} \mathrm{E}$, covers $20,826 \mathrm{~km}^{2}$ and has many forests on hilltops or plateaus, both gazetted and ungazetted and wooded lands. Kirisia Forest also known as Leroghi (initially 92,000 ha but now less than 78,000 ha) is one of the gazetted State Forests. Ungazetted forests and wooded lands are mostly found on communal land managed under Group Ranch tenure system; the land is under Trust by the Samburu County Council. Kirisia forest is located at an altitude ranging from 2,000 to 2,200 $\mathrm{m}$ above sea level with mean annual rainfall of $600-750 \mathrm{~mm}$ at $1945 \mathrm{~m}$ a.s.l. and the mean annual temperature of between 24 and $33^{\circ} \mathrm{C}$ (Jaetzold and Schmidt, 1983). There are three wet rainfall peaks in a year, and two driest months: January and February. According to Jaetzold and Schmidt (1983), the general fertility of the soils in the forest is variable and soils are shallow. The area around the forest is dominated by a complex of well-drained, shallow, black to very dark brown, acid humic, very friable loam soils.

The overall density of Kirisia Forest varied as follows: seedlings ${ }^{2}$ (1537 ha-1), Saplings ${ }^{\dagger}(1322$ ha-1), Pole-sized trees ${ }^{\dagger}$ (196 ha-1 equivalent to $21.2 \mathrm{~m}^{2} \mathrm{ha}^{-1}$ ) and Large trees ${ }^{\dagger}$ (86 ha-1

2 Seedlings $=$ Stems $<1 \mathrm{~m} \mathrm{Ht} ;$ Saplings $=$ Stems $1 \mathrm{~m} \mathrm{Ht}-10 \mathrm{~cm}$ dbh; Pole-sized trees $=$ Stems $\geq 10-20 \mathrm{~cm}$ $\mathrm{dbh}$; Large trees $=$ Stems $\geq 20 \mathrm{~cm}$ dbh 
equivalent to $24 \mathrm{~m}^{2} \mathrm{ha}-1$ ) (Hitimana et al., 2009). Overall, four species dominate the forest top canopy: Olea europaea ssp africana (up to $34 \%$ ), Juniperus procera (up to 25\%), Podocarpus falcatus (up to $26 \%$ ) and Croton megalocarpus (15\%). Those species dominating the middle canopy all blocks combined were P. falcatus (12-45\%), O. europaea ssp africana (21 -28\%), J. procera (20 \%), Teclea simplicifolia (13-15\%) and C. megalocarpus (12 \%) (Hitimana et al., 2009). Beentje (1990) described floral composition of Kirisia Forest as having different vegetation associations, dominated by large tree species above in addition to Nuxia congesta on much of the hills; and Cassipourea malosana on wetter slopes. Understorey tree species include Teclea nobilis, Maytenus undata, and Acokanthera schimperi and Mystroxylon aethiopicum. The forest is also a mixture of open, disturbed and rocky areas covered with Euclea divinorum, Carissa edulis, Rhus natalensis and Croton dichogamus small trees and shrubs. Regeneration of the tree component is characterized by saplings totaling 1322 individuals per hectare shared among 62 out of 95 tree species recorded above $10 \mathrm{~cm}$ dbh. Overall, 11 species formed the bulk of regeneration in the entire Kirisia forest. Seedlings total 1537 individuals per hectare distributed among 46 tree species among the 95 recorded above $10 \mathrm{~cm} \mathrm{dbh}$. That is, about $52 \%$ of tree species in Kirisia did not have seedlings during the time of the survey. This is a huge deficiency.

The faunal and avi-faunal diversity in Kirisia Forest Reserve is very high throughout the forest. The forest is on overall an important habitat for wildlife, thus a hot spot for biodiversity conservation and a potentially important attraction for tourism development. However, the rich wildlife in the forest cannot be sustainably managed without the integration of the adjacent dispersal areas through the participation of the adjacent Group Ranches and individual land owners. These ranches are crossed by several migratory wildlife routes and corridors (Figure 2) which link major wildlife habitats within the Samburu Heartland.

For communities around the forest, the main land tenure system is communal $190 \%$ of households; $10 \%$ of households are located either on private land or State owned land in the forest through encroachment). The communal land is divided into Group Ranches, shared by registered members who are allowed to graze or establish homes (manyattas) anywhere. Figure 3 show land tenure context around the forest. The forest is bordered by 13 group ranches and the study focused on all group ranches.

The ownership of the wider Kirisia forest ecosystem is mixed: a community resource and a national resource. The State Forest Reserve is enclosed between community-owned land (Group Ranches) often with unclear demarcations of boundaries. In addition, reports about migratory bird species from as far as Europe and Asia being traced within the forest during some periods of the year, its uniqueness as a habitat and / or corridor for some of the protected wildlife species such as elephants reflect the international interests about this forest in terms of conservation biology. Despite its importance to many, the Kirisia forest ecosystem has no defined management model and is under threat of mismanagement leading to degradation and human encroachment for settlements.

\subsection{Description of the sampled community representatives}

Respondents came from a sample representing all age-categories of heads of households and gender (Table 1). Based on the age and gender structure of the respondents, the views were captured from adult community as a whole and there was fair representation of both age and gender. The group of respondents below 55 years is made of active members in the 


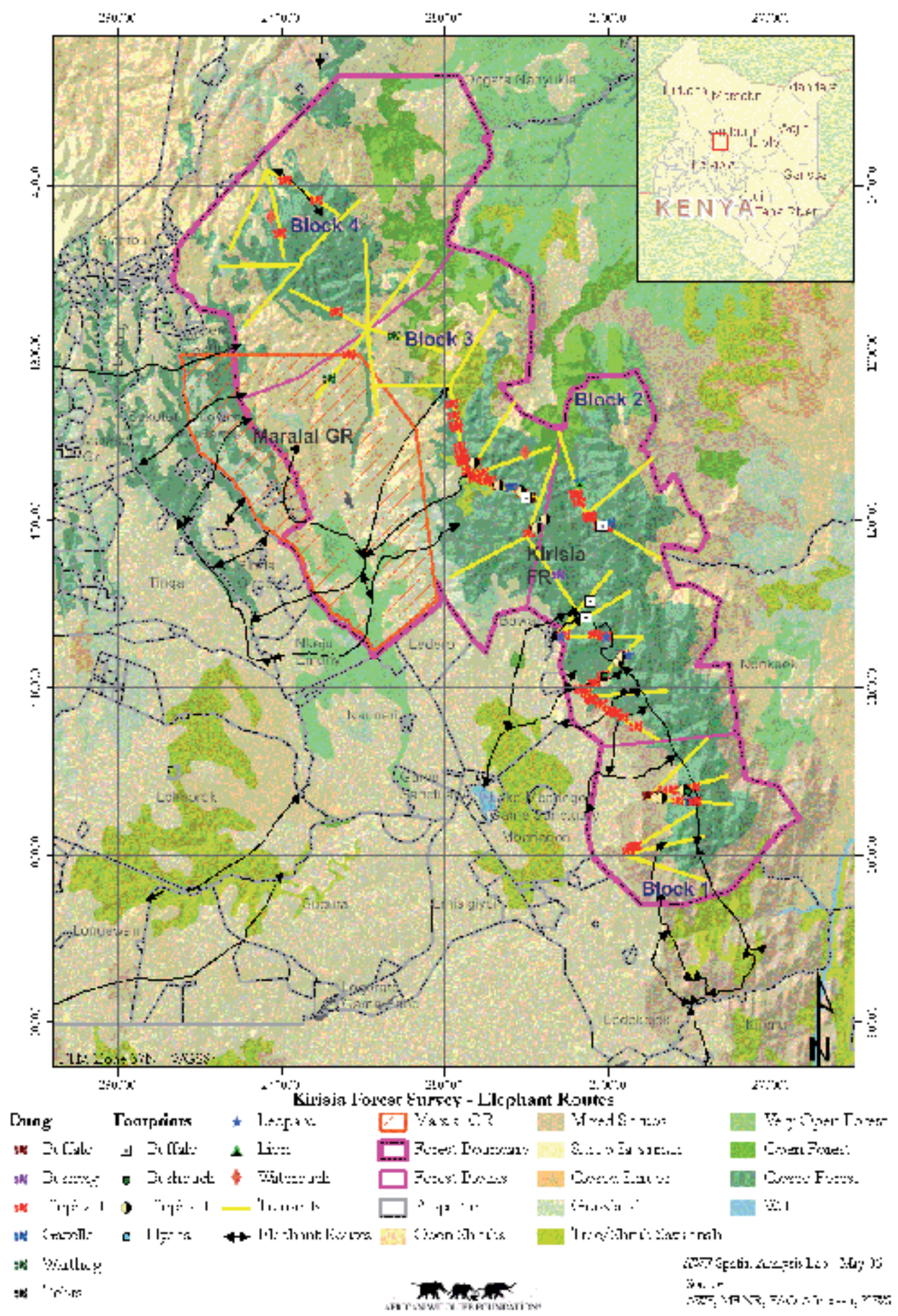

(Source: Hitimana et al., 2009)

Fig. 2. Movement of wildlife within and around Group Ranches west of Kirisia Forest Reserve, Samburu Heartland. 


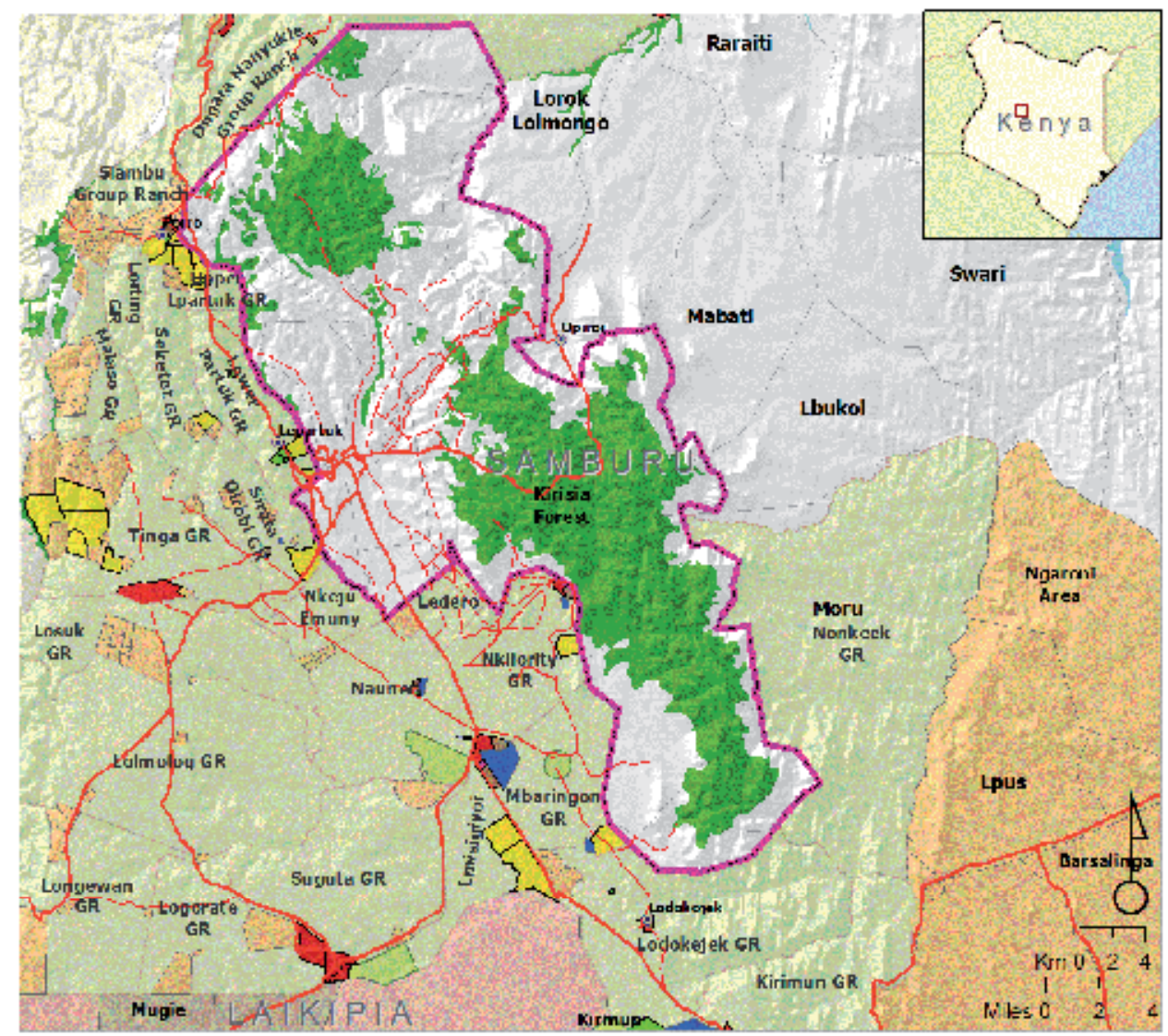

Kirisia Forest: Land Tenure Context

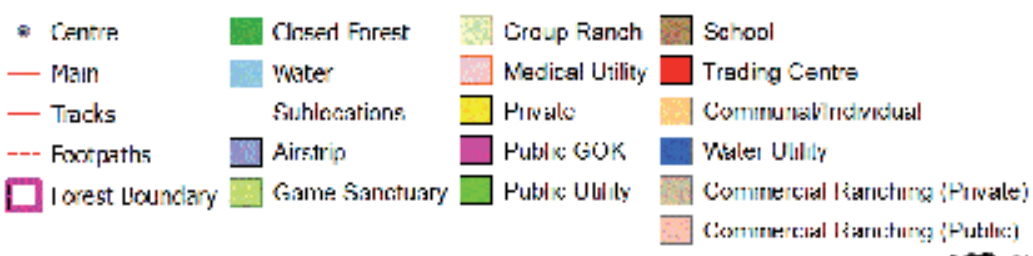

Sxex::

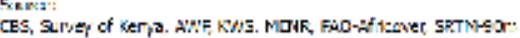

wht spas ind, as Las

hintertint.

(Source: Hitimana et al., 2009)

Fig. 3. Land tenure context in Group Ranches west of the Kirisia Forest Reserve, Samburu Heartland.

community as far as the country's workforce is concerned. Many households were represented by female (mostly wives) due to the lifestyles whereby male heads of households are out guarding grazing livestock. The general literacy and education levels of the rural Samburu community around Kirisia forest were low.

\subsection{Survey techniques}

Human dependence on the Kirisia Forest Reserve was analyzed through intensive socioeconomic study based on guided personal interviews in the forest and outside, to enhance 


\begin{tabular}{llr}
\hline Parameter & Categories & $\%$ \\
\hline Age class (year) & $25-55$ & 60 \\
& Below 25 & 29 \\
& Above 55 & 55 \\
\hline Sex & Male & 52 \\
& Female & 48 \\
\hline Top education level & Informal & 85 \\
& Primary & 10 \\
& Secondary & 5 \\
& Post-secondary & 0 \\
\hline
\end{tabular}

Table 1. Description of the sampled community representatives.

sustainable forest use and improve livelihoods of forest adjacent communities. Interviews were undertaken in October to December 2005. Socio-economic survey was carried out using structured questionnaires and personal interviews in Group Ranches around the forest. The study focused on all Group Ranches. Cluster sampling was used in selection of the villages. The ranches formed the clusters and the villages were selected on cluster basis and not on individual village basis. Random sampling was then used in the selection of the manyattas and respective households to be interviewed. The survey was carried out on the households adjacent to the forests or within $5 \mathrm{~km}$ radius from the forest edge to generate the primary data to be used for the study. A total of 12 households were randomly selected for each Group Ranch. The study targeted the household heads as the main respondents for the interview, in whose absence an alternative respondent, that is, the next in rank to the household head such as the spouse, a son or a daughter above 18 years of age conversant with forest-based household economy. Informal interviews and discussions with field guides during ecological surveys (Hitimana et al., 2009) provided additional useful socioeconomic data about the resource and people depending on it. Field guides were knowledgeable individuals selected from and by the local communities. Ecological survey covered the entire forest subdivided into four forest blocks. Human activities were observed with 0.02 ha-plots arranged along transects (Table 2; Figure 4). Data were collected along a total of 32 transects (up to $5 \mathrm{~km}$ ) cutting across forest sites and vegetation types.

\subsection{Socio-ecological and socio-economic attributes of interest}

1. Local guides helped to capture information on forest uses, conflicts and species types:

- Evidence of extractions of timber and non-timber forest products e.g. pasture / fodder and guidelines that can be used to regulate such extractions

- $\quad$ Evidence of bee-keeping related activities outside and inside the forest

- List of medicinal plant species used and parts from which medicines are extracted

- Inventory of possible ecotourism ventures that can be developed including those already being practiced: list of unique forest sites, viable trails and associated attractions

- List of socio-cultural uses of the forest and evidence of their impact in conservation 
- $\quad$ Evidence of negative influence of forest to people e.g. human wildlife conflicts

2. Households' heads provided data on social, economic and cultural values attached to the forest.

\begin{tabular}{|c|c|c|c|c|}
\hline \multirow[t]{2}{*}{ Blocks } & \multicolumn{4}{|c|}{ Pre-inventory descriptions } \\
\hline & Located in & $\begin{array}{l}\text { No. of } \\
\text { Transects }\end{array}$ & $\begin{array}{l}\text { No. of } \\
0.02-h a \\
\text { plots }\end{array}$ & Human-forest interface \\
\hline Baawa & Loroki Division. & 6 & 20 & $\begin{array}{l}\text { Adjacent to few human settlements. } \\
\text { Beekeeping and ecotourism are practiced }\end{array}$ \\
\hline Tamiyoi & $\begin{array}{l}\text { Kirisia Division, } \\
\text { between Baawa } \\
\text { and Olpiroi } \\
\text { Dams. }\end{array}$ & 10 & 38 & $\begin{array}{l}\text { Closest block to Marallal Town and } \\
\text { adjacent to high concentration of human } \\
\text { settlements. Beekeeping and high number } \\
\text { of livestock are found in the forest. }\end{array}$ \\
\hline Rapar & Kirisia Division & 10 & 39 & $\begin{array}{l}\text { Adjacent to high concentration of human } \\
\text { settlements. High population of livestock } \\
\text { is found in the forest. }\end{array}$ \\
\hline Nkorika & Kirisia Division & 6 & 25 & $\begin{array}{l}\text { Adjacent to low concentration of human } \\
\text { settlements but high number of livestock } \\
\text { found in the forest. }\end{array}$ \\
\hline Total & & 32 & 122 & \\
\hline
\end{tabular}

Table 2. Pre-inventory description of different sample blocks.

\subsection{Data analysis}

Social, economic and cultural values of the forest for the local communities were described based on informal interviews. The current and potential socio-economic and cultural benefits from Kirisia Forest were analysed and indicated an overall picture of human dependence on the ecosystem in terms of wood and non-wood products. Forest-human interactions were analysed with respect to bee-keeping, harvesting of medicinal plants etc. Human-wildlife conflicts were derived from informal interviews with local guides and local communities in Group Ranches. Mapping and geo-referencing ecological, water and ecotouristic resources within the forest was made as a guide for future development of ecofriendly enterprises to boost livelihoods of local communities. The types of shelters observed and the dominant materials used in putting up the buildings were used as indicators of the wealth status of different households.

\section{Results}

\subsection{Pillars of households economy in group ranches around Kirisia Forest}

There are direct and indirect benefits people derive from forests (Table 3). Livestock keeping is the most dominant primary occupation (Table 4). The Kirisia forest plays a very important role in local people's daily lives by being the main resource for dry season grazing and water for this largely pastoral community. The number of households involved in farming (crop cultivation) as their major occupation was quite higher than expected and had low number of domestic animals (generally less than ten cows per household). Agricultural crops included maize (Zea mays), sorghum (Sorghum bicolor), wheat (Triticum aestivum) and 


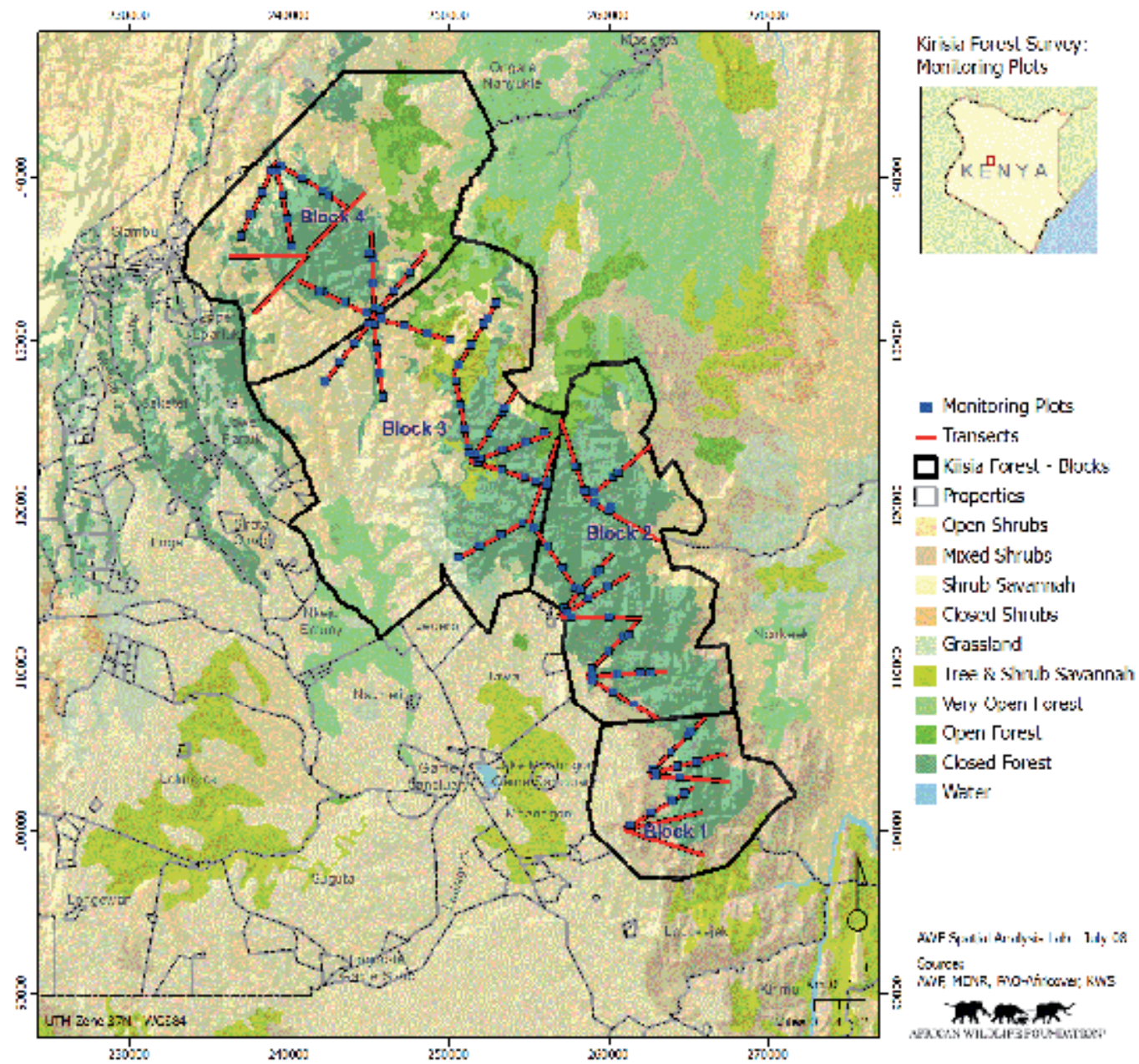

Fig. 4. Distribution of belt transects and sampling plots within Kirisia Forest, 2005 Block IDs: Rapar (Block 1), Baawa (Block 2), Tamiyoi (Block 3) and Nkorika (Block 4) (Source:

Hitimana et al., 2009).

other crops that are drought tolerant. Crop growing near the forest - a habitat to high diversity of wildlife including birds and herbivores - is one potential source of wildlife human conflict as crops are often raided and damaged.

A small percentage of households relied on off farm activities as their primary occupation, especially trading and permanent employment such as teachers. The community literally has no alternative source of livelihood; only livestock and farming for those who don't have them as a primary occupation. In view of these findings, by and large, the community's household economy was mainly based on land resource for cultivation or livestock grazing. The forest plays a key role in livestock and agricultural development in the area as a source of water, pasture and fodder particularly during dry seasons. The forest has also been the main source of wood for domestic use (construction and fuel) and rarely for income generation (Table 4). 


\begin{tabular}{lll}
\hline Direct values & Indirect values & Constraints \\
\hline Firewood (Fuelwood and Charcoal) & Rain attraction & Acquisition of \\
Water & Wind breaks & permits \\
Timber and Building posts & Aesthetic value & Policing \\
Fruits & Cultural and religious & Wildlife conflicts \\
Thatching grass & uses & \\
Honey & Water conservation & \\
Medicinal herbs & Wild animal habitat & \\
Traditional tools & Erosion control & \\
Bee hives & & \\
Wild meat & & \\
Grazing and fodder & & \\
Employment & & \\
Eco-tourism & & \\
\hline
\end{tabular}

Table 3. Benefits local people derive from Kirisia Forest, Samburu, Kenya.

\begin{tabular}{lll}
\hline Parameter & Categories & $\%$ \\
\hline Primary occupation & Farming & 35 \\
& Livestock keeping & 60 \\
& Off-farm employment & 5 \\
& Livestock alone & 52 \\
& Farming alone & 40 \\
& Both livestock and farming & 8 \\
\hline Secondary occupation (alternatives) & Farming & 50 \\
& Livestock keeping & 40 \\
& None & 10 \\
\hline Wood for construction & Shelter as wooden houses & 85 \\
& Mud houses & 7 \\
& Stone houses & 8 \\
\hline Source of Firewood & Kirisia State Forest & 78 \\
& Group Ranch & 22 \\
\hline Use of firewood & Commercial & 1 \\
& Domestic & 99 \\
\hline
\end{tabular}

Table 4. Levels of dependence on land and wood for livelihoods for households adjacent to Kirisia Forest, Kenya, 2005.

\subsection{Households dependence on Kirisia Forest}

According to interviews returns, the Kirisia Forest was highly valued by the local people as the source of firewood, pasture, posts, water, medicinal herbs and rain in a descending order (Figure 5). From ethno-botanico-ecological survey additional details of the forest value were noted. Several tree species were identified as source of fodder for livestock, others as high quality bee forage, and others were source of food for humans. Most of the forest products are harvested for household use (Table 5); hence the community does not view the forest as a source of income as much. Posts were used in the construction of manyattas 


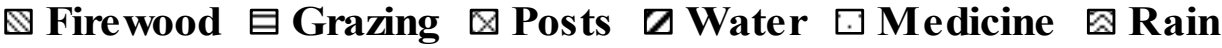

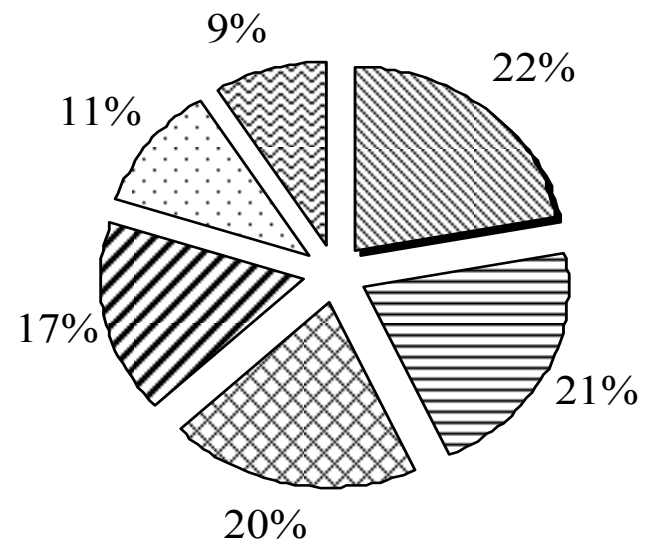

(Source: Interviews with local communities)

Fig. 5. The most important products derived from Kirisia Forest, Kenya, 2005.

(traditional samburu/maasai houses) and for fencing, which very common even in the nearby Marallal town, the single most important market outlet of commercialised forest products from Kirisia. Preferred species for fencing was Juniperus procera due to its durability in the ground and resistance to termites attack. Quite a high percentage of households were involved in herbal medicine as an income-generating activity in local markets. Charcoal making in Kirisia, was seen emerging in the forest blocks near Maralal township (e.g. Tamiyoi block) though it was not mentioned during interviews. Sites of charcoal production (including live kilns) were encountered within the forest, though not many. However, this activity, if uncontrolled and uncoordinated, is potentially a major threat to the integrity of the ecosystem, as urbanization coupled with increasing change in lifestyle of the nomadic pastoral communities continue to set in.

\begin{tabular}{lrr}
\hline Uses of products & Posts & Medicinal herbs \\
\hline Domestic alone & $55 \%$ & $50 \%$ \\
Commercial alone & $10 \%$ & $46 \%$ \\
Both domestic \& Commercial & $35 \%$ & $2 \%$ \\
Undisclosed & $0 \%$ & $2 \%$ \\
\hline
\end{tabular}

Table 5. Percentages of households adjacent to Kirisia Forest that use posts and medicinal plants for domestic or commercial purposes, 2005.

\subsubsection{Pasture / fodder for livestock}

The Kirisia forest plays a very important role in local people's daily lives by being the main resource for dry season grazing and water source for this largely pastoral community. Pollarding of trees for fodder was found common but targeting a few species. About $42 \%$ of damaged tree individuals (187 out of 451), belonging to eight different species, were pollarded for calves or as dry season source of fodder for the livestock; the most popular 
and affected species was Olea europaea ssp africana (Table 6). However, ethnobotanical survey revealed over 16 woody species (Table 7) that were actually recognized by the locals as fodder species; that is, $16.8 \%$ of the 95 tree species identified in the sample plots. It was noted that a few (three) of the commonly known fodder species were target in the "cut-andcarry system" of the dry season intensive exploitation of fodder. The fact that pollarding was observed to many more species than those listed as common fodder species implied that, during dry season, people expand the range of fodder species to include those that are usually not easily accessible e.g. requiring climbing during fodder harvesting. The impact of collecting fodder from palatable tree species through pollarding is exceptionally worrying; it is unprofessional, unplanned and uncoordinated. Table 8 shows the three most frequent damages on trees per block.

\begin{tabular}{|c|c|c|c|c|c|c|c|c|}
\hline \multirow[t]{2}{*}{ Forest Block } & Rapar & Baawa & Tamiyoi & Nkorika & \multicolumn{4}{|c|}{ Entire Forest scenario (28.3 ha - sample size) } \\
\hline & $\mid \begin{array}{l}\text { Pollarded } \\
\text { trees }\end{array}$ & $\begin{array}{l}\text { Pollarded } \\
\text { trees }\end{array}$ & $\begin{array}{l}\text { Pollarded } \\
\text { trees }\end{array}$ & $\begin{array}{l}\text { Pollarded } \\
\text { trees }\end{array}$ & $\begin{array}{l}\text { Total } \\
\text { damaged } \\
\text { trees }\end{array}$ & $\begin{array}{l}\text { Pollarded } \\
\text { trees }\end{array}$ & $\begin{array}{r}\text { Pollarded \% per } \\
\text { species }\end{array}$ & $\begin{array}{l}\text { Share of } \\
\text { pollarded trees } \\
\text { among species }\end{array}$ \\
\hline Teclea simplicifolia & 4 & 1 & 0 & 0 & 10 & 5 & 50.0 & 2.7 \\
\hline Olea europaea & 30 & 78 & 31 & 28 & 269 & 167 & 62.1 & 89.3 \\
\hline Grewia tembensis & 1 & 0 & 0 & 0 & 2 & 1 & 50.0 & 0.5 \\
\hline Juniperus procera & 2 & 1 & 2 & 0 & 139 & 5 & 3.6 & 2.7 \\
\hline Croton megalocarpus & 0 & 2 & 0 & 0 & 13 & 2 & 15.4 & 1.1 \\
\hline Euclea schimberi & 0 & 4 & 0 & 0 & 15 & 4 & 26.7 & 2.1 \\
\hline Lamaroki / Lamarogi & 0 & 0 & 1 & 0 & 1 & 1 & 100.0 & 0.5 \\
\hline Ngeriyoi & 0 & 0 & 2 & 0 & 2 & 2 & 100.0 & 1.1 \\
\hline Total & 37 & 86 & 36 & 28 & 451 & 187 & 41.5 & 100.0 \\
\hline \% pollarded per locality & 29 & 49 & 34 & 65 & & 41 & & \\
\hline
\end{tabular}

Table 6. Pollarded species for livestock fodder and other products and magnitude of the practice in Kirisia forest.

\begin{tabular}{|l|l|}
\hline Olea capensis ssp hotchstetteri (Lolionti) - & Mystroxylon aethiopicum (Lodonganayioi / \\
Dry season fodder & Saramonai / Lodonganayai) \\
Olea europaea (Lngeriyoi) - Dry season & Pavetta abyssinica (Ljeni Ebor) \\
fodder & Rhus natalensis (Msigioi / Lmisigiyioi / \\
Carissa edulis (Sangumai / Sakumai / & Lmisigiei) \\
Sagumai/ Lamuriai) & Teclea simplicifolia or Cadia purpurea (Lgirai / \\
Celtis africana (Lekere / Lekiri / Ngisitet & Lgiriyai) \\
/ Nekiri) & Kosintet / Ngositet \\
Dombeya sp. (Lporokwai) & Lamaroki / Lamarogi \\
Erythroccoca bongensis (Leshapirik / & Machakudu / Lcokudu \\
Lechopiriki / Lesopirik) & Ngeni-Niok / Njeni-Nayok \\
Grewia tembensis (Irri / Iriei) & Rhammus staddo for goats \\
\hline
\end{tabular}

Table 7. The 16 fodder tree species recorded during the ethnobotanical survey in Kirisia.

\subsubsection{Human food and hygienic products}

Kirisia Forest is one of the sources of food and other nutrition-related products (Table 9). It is a major source of wild honey used locally and sold in the area. The survey revealed 18 woody species $(18.9 \%)$ from which food and other domestic uses of non-wood forest 
products (NWFP) were collected. Tree species such as Clausena anisata, Teclea simplicifolia or Cadia purpurea (Lgirai / Lgiriyai), Justicia sp. and Calodendrum capense (Larashi) are used for cleaning teeth (toothbrush).

- $\quad$ Rapar Block: - Pollarding (29\%), debarking (23\%) and dead (13\%)

- Baawa Block: - Pollarding (49\%), Heart $\operatorname{rot}(19 \%)$ and debarking $(8 \%)$
- $\quad$ Tamiyoi Block:- Debarking (34 \%), pollarding (31 \%), dead (15\%).

- Nkorika Block: - Pollarding (65\%), debarking $(13 \%)$ and disease $(13 \%)$

Table 8. Major damages inflicted on trees in Kirisia Forest.

\begin{tabular}{ll}
\hline Nutrition and Hygiene & Species \\
\hline Edible fruits but poisonous leaves & Acokanthera schimperi (Murichoi /Lmorijoi) \\
Edible fruits & Lmai; Lgormoshio; Vangueria madagascarensis \\
Edible gum & Grewia tembensis (Irri / Iriei) \\
Edible seeds & Dovyalis abyssinica (Lmoroo / Moroo) \\
Vegetable leaves & Euclea schimberi or E. divinorum (Nchinyei /Lchingei) \\
Honey unfit for expectant women & Lpinai / Lbenai \\
Aromatic spice & Lominyanyi \\
Appetizer & Lokujok \\
Milk gourd cleaning & Tarenna graveolensis (Lmasei) \\
Stimulant as Aphrodisiac & Longariboi; Lorekiri; Ekebergia capensis (Songoroi) \\
\hline
\end{tabular}

Table 9. Kirisia Forest as a source of human food and other NWFP used in households.

\subsubsection{Beekeeping and honey extraction}

The use of forest as source of honey was apparent from both socioeconomic interviews in Group Ranches and from ethno-botanical survey inside the forest: $70 \%, 10 \%$ and $20 \%$ of households using honey obtained it from the Kirisia Forest, on the Group Ranches land, or purchased from honey gatherers/producers around the forest. From all households that harvested/hunted honey did so for: (i) domestic uses only $(54.3 \%)$, income generation only $(2.5 \%)$ or both $(43.2 \%)$. Local people heavily depend on the Kirisia State Forest for honey by collecting wild honey and/or hanging hives inside the forest. Even emerging beekeeping outside the forest (e.g. Group Ranches) using different kinds of beehives still depends on the forest as a habitat for a diversity of bee forage which influence the properties and quality of honey produced, and as a source of permanent water even when all water points have dried outside the forest e.g. during droughts. Popular bee-forage tree species were Mystroxylon aethiopicum (Lodonganayioi / Saramonai), Lpinai, Machakudu/Lcokudu, Lmuzungach and Mukinyeyi. Honey gathering in the wild was the most common method of harvesting honey supplies for households. Modern beekeeping was still at infant stage in the Kirisia area; being practiced by a few progressive beekeepers. The indigenous technique used to harvest honey from forests used fire and felling of trees to access honey up the stem, at a height beyond reach from the ground. This technique is wasteful, very destructive and nonsustainable. Eight species, all of them in the upper canopy, were damaged through honey harvesting using fire and axes (Table 10).The most affected species were Juniperus procera and Olea europaea ssp africana. Promoting efficient beekeeping and honey extraction technologies can play several roles: increased yield and income, and protection of tree 
species otherwise damaged by traditional practices and other components of the ecosystem depending on them.

\begin{tabular}{lccc}
\hline & $\begin{array}{l}\text { Damaged trees using axes or } \\
\text { machettes for honey harvesting } \\
\text { from tree stems }\end{array}$ & $\begin{array}{l}\text { Burnt trees during honey } \\
\text { harvesting }\end{array}$ & Total \\
\hline Machakudu / Lcokudu & 1 & 0 & 1 \\
Croton megalocarpus & 0 & 1 & 1 \\
Mystroxylon aethiopicum & 0 & 1 & 1 \\
Teclea simplicifolia & 1 & 0 & 1 \\
Podocarpus falcatus & 1 & 3 & 4 \\
Croton megalocarpus & 1 & 1 & 2 \\
Juniperus procera & 5 & 15 & 20 \\
Olea europaea & 1 & 32 & 33 \\
\hline Total & 10 & 53 & 63 \\
\hline
\end{tabular}

Table 10. Tree species damaged through wild honey harvesting from Kirisia Forest, Samburu, 2005.

\subsubsection{Medicinal plants (herbs)}

Fifty four percent $(54 \%)$ of the respondents acknowledged the medicinal value of Kirisia forest to humans. Over $92 \%$ of them collected medicinal herbs solely for domestic uses, $4 \%$ for commercial purposes to generate income and another $4 \%$ for both domestic and commercial. At least 30 species of the 95 recorded woody plant species (over $30 \%$ ) were reported as being of high medicinal value, used by local people in herbal medicine to treat diverse ailments (Table 11).

Herbs were also used to treat livestock e.g. de-worming (Olea europaea ), placenta removal after birth (Olinia rochetiana) and tapeworms (Lorekiri). Calodendrum capense produces a perfume. Kirisia area remains a potential research site for further investigations in how to promote herbal medicine for biodiversity conservation and improved livelihoods of local people. This aspect is a strong entry point in joint / participatory forest management scheme.

Different parts of the plant were harvested as medicinal: leaf extract (Justicia sp., Trimeria grandifolia), Bark extract (Croton megalocarpus, Juniperus procera, Mystroxylon aethiopicum, Olinia rochetiana, Lokujok, Podocarpus falcatus, Vangueria sp, Lorekiri, Trimeria grandifolia), Root extract (Trimeria grandifolia, Rhamnus prinoides (concoction), Rhammus staddo, Carissa edulis, Croton dycotomous, Dombeya sp., Euclea schimberi /E. divinorum, Rhus natalensis, Teclea simplicifolia / Cadia purpurea, Toddalia asiatica, Euphorbia candelabrum, stem or twig sap (Euphorbia candelabrum, Aloe secundiflora), fruits (Myrsine africana). The harvesting of barks, roots and stems is a threat to plant life and potentially not sustainable. There is need to promote low impact harvesting technologies and other conservation measures to protect threatened medicinal plants, both inside and outside the forest. 


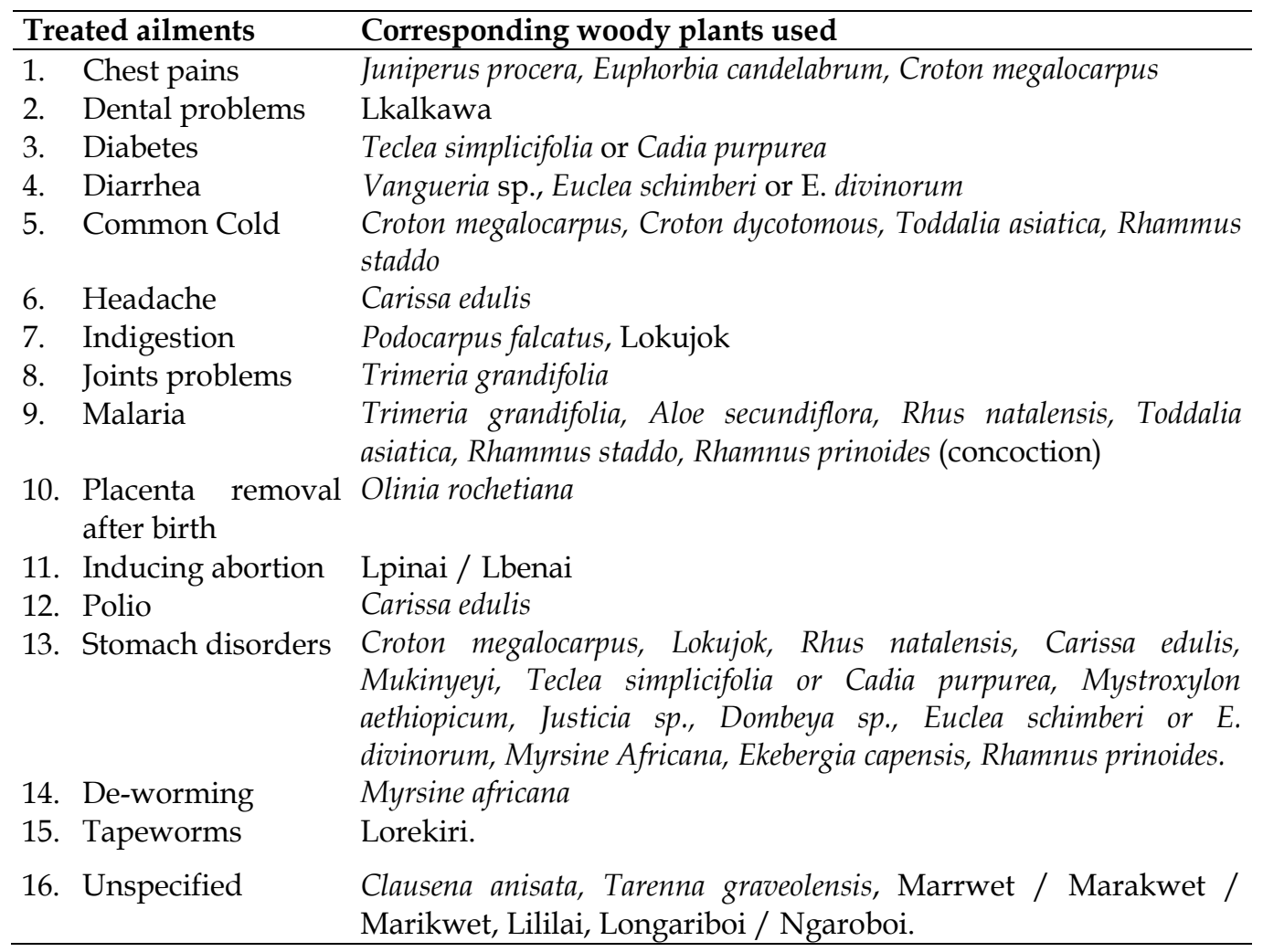

(Source: Personal interviews with local people, 2005)

Table 11. Herbal woody plant species recorded in Kirisia forest based on indigenous knowledge, 2005.

\subsection{Cultural value of the forest to local communities}

The Samburu community attaches strong cultural value to the Kirisia forest and tree resources in general. Different forest plants and plant parts are used in various cultural ceremonies (Table 12). Birds constitute an important forest-based natural resource used in ceremonies and that also attract bird-watching tourism. Conservation measures including community sensitization should be put in place to minimize destructive uses of bird resource e.g. killing to collect feathers for traditional ceremonies such as boys' circumcision, and instead optimize income accruing from bird-based ecotourism and research.

\subsection{Ecotourism development opportunities}

Ecotourism development is an important nature-based enterprise that can significantly generates income from both local and international visitors to Kirisia area and its environs, benefiting not only the State but also local people. Local people benefit from ecotourism in various ways: employment as tour guides, as owners of camping sites, availability of market (buyers) for local artists, booming business in the hotel industry (guest houses).

The Kirisia forest and the surrounding landscape are rich in wildlife and other attractive features. The presence of this closed canopy forest within a dryland region is an attraction 
in itself. The forest rich biodiversity in terms of plant types and animal life (mainly mammals and birds) is quite attractive. Such benefits motivate beneficiaries in conserving the resource base for the ecotourism enterprise. Figures 6 and 7 mapped spatial distribution of animal wildlife and other attractive features within the Kirisia Forest Reserve, Samburu, Kenya, 2005.

\begin{tabular}{llll}
\hline Events & Plant use & Plant species & Plant parts used \\
\hline Circumcision & Symbol of blessing & Ltarakwai & Branches \\
& Making fire & Sucha & Leaves \\
& Symbol of peace & Lchingei & Branches \\
& Symbol of ceremony & Lgeriyoi, Lgilai, Lkukulai, & Branches \\
& & Silapai, Tepes, Girigira & \\
& Ngerie & Leaves and \\
& & branches \\
\hline Marriage & Symbol of blessing & Lgeriyoi, Ltarakwai, Lgilai, & Branches \\
& Lkukulai & Leaves \\
& Incense for good & Nasungoyo & \\
\hline Sacrifices & Symbll & & Branches \\
\hline
\end{tabular}

Table 12. Socio-cultural uses of the Kirisia Forest plants by Samburu community, Kenya.

\subsubsection{Wildlife richness in Kirisia Forest}

During the ethno-ecological survey, local guides assisted to identify animal wildlife resources existing in the forest based on evidences such as footprints, feaces, and carcasses of dead animals, sounds, sighting and damages to plants. The faunal and avi-faunal diversity in Kirisia Forest Reserve was very high (herbivores, carnivores, birds, insects) throughout the forest as revealed by several indices (Figure 7). The forest provides fodder / food to herbivores (grazers and browsers), granivores (seed or grain-eaters), fruigivores (Fruits-eaters), carnivores etc. A high diversity of grazers is found in forest gaps (glades) and under open canopy. Similarly, there are carnivores surviving on the different types of the first consumers.

Samburu pastoralists have a very rich indigenous knowledge about the Kirisia forest resources owing to the fact that they have coexisted with and depended on the forest from time immemorial. Trees play an important role in the nutrition of wildlife. Nine tree species out of 95 were recorded as source of fodder for wildlife (Table 13). The checklist of wild animals living in the forest (presence / absence records from the October - November 2005 survey) is annexed (Appendix A) as well as over 60 species of birds encountered and identified in the surveyed parts of the forest (Appendix B)

\subsubsection{Forest disturbance by wildlife: An opportunity costing of ecotourism}

Forest disturbances associated with animal wildlife included debarked by elephants, defoliation/browsing by elephants and other browsers, injuries (including breaking and falling / uprooting) by buffalos and elephants mainly, and death (dying and dead trees) mainly as a result of excessive debarking or burning for honey collection. In the surveyed area (28.3 ha sample), a total of 17 species were found damaged by wild animals, with a magnitude of 198 out of a total of 475 individual trees damaged by different kinds of factors (i.e. 7 out of 17 damaged trees / ha; $41 \%$ ) (Table 14). 


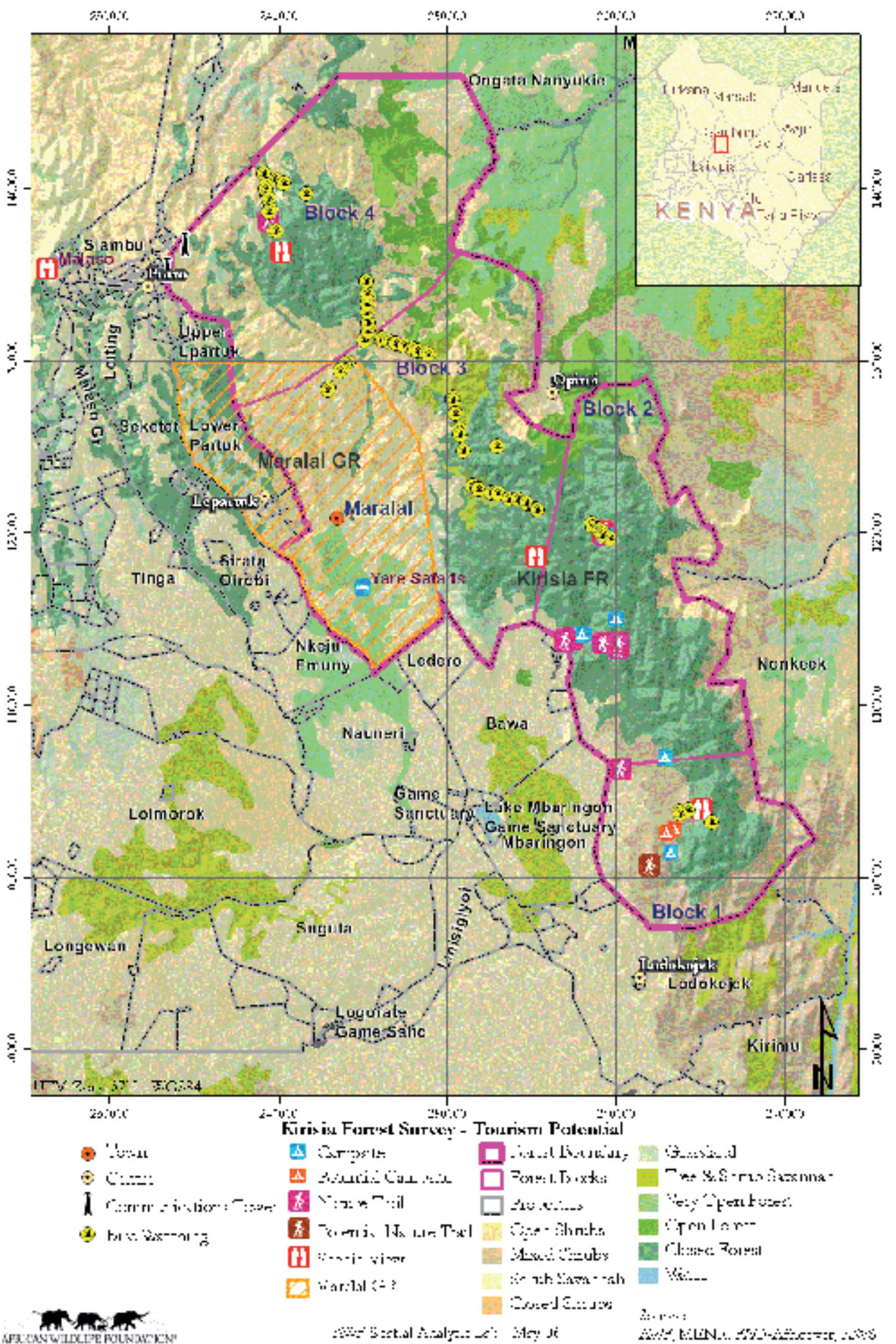

Fig. 6. Mapped spatial distribution of ecotouristic attractive features within the Kirisia Forest Reserve, Samburu, Kenya, 2005. 


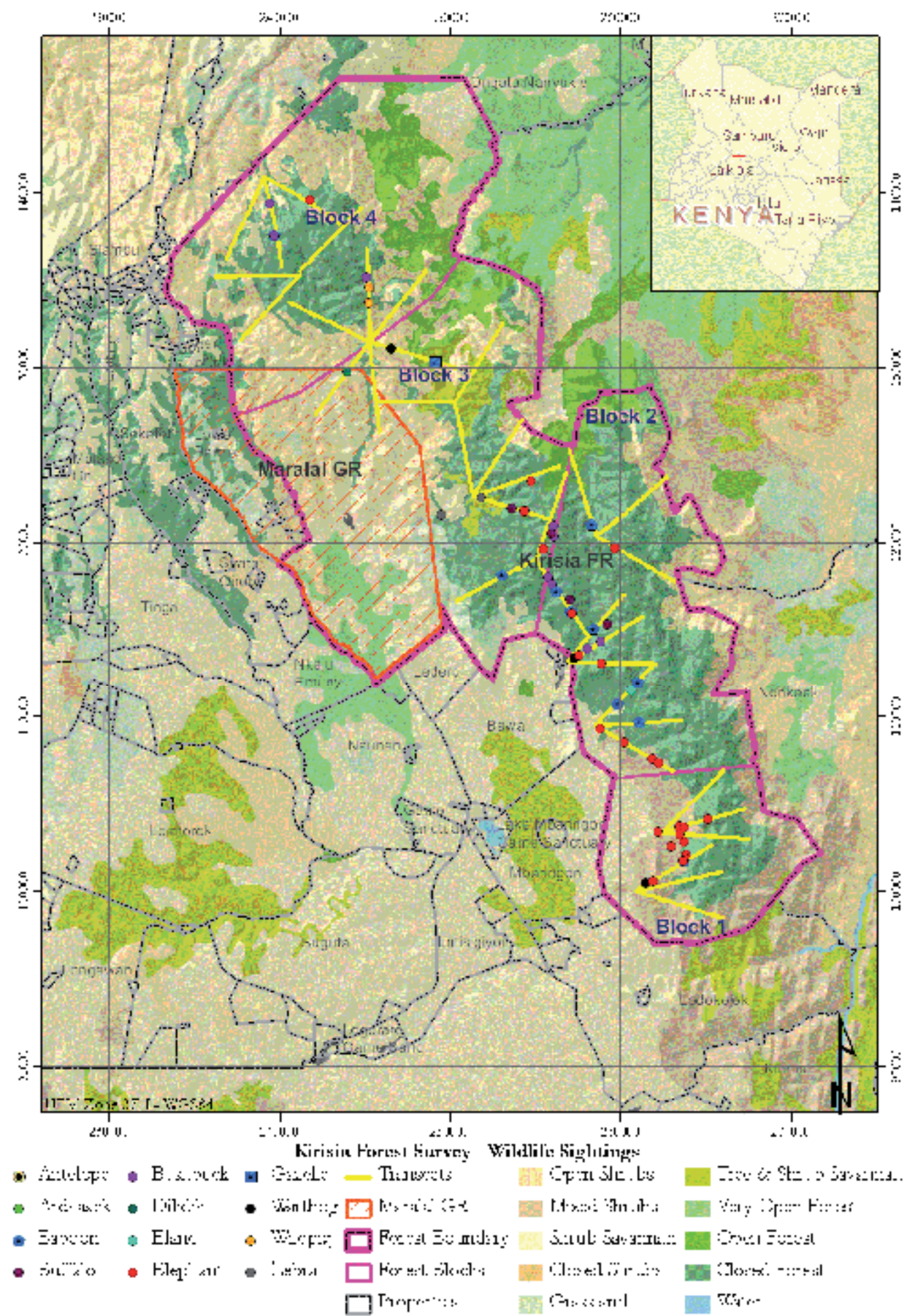

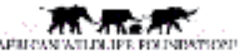

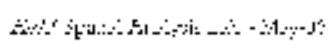

sols:

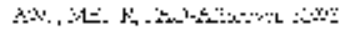

Fig. 7. Spatial distribution of animal wildlife within the Kirisia Forest Reserve, Samburu, Kenya, 2005. 
The most affected species were Juniperus procera (51\%) and Olea europaea ssp africana (29\%) through debarking and other injuries, often resulting in death of trees. Besides direct physical damage on trees, large populations of elephants, buffalos and other herbivores for wildlife and cattle for livestock affected the Kirisia ecosystem through trampling and destroying regeneration. The survey in plots indicated that the area of permanent paths and animal trails was on average $135 \mathrm{~m}^{2} /$ ha. That is, $1.4 \%$ (range: $0.6-2.1 \%$ ) of land surface were rendered unproductive through trampling (Table 15).

Damages inflicted on the ecosystem integrity as a result of wildlife can be viewed as a component of ecotourism opportunity cost, at least on the ecological side.

\begin{tabular}{|l|l|l|}
\hline Wildlife & Feeding type & Woody species \\
\hline Elephants & Browsing & $\begin{array}{l}\text { Euclea schimberi or E. divinorum (Nchinyei / Lshingei/ } \\
\text { Lchingei/Ljenyei), Trichocladus ellipticus (Balagalagi / } \\
\text { Lpalagilagi, Calidendrum capense (Larashi) }\end{array}$ \\
\hline & Debarking & Teclea simplicifolia or Cadia purpurea (Lgirai / Lgiriyai) \\
\hline Birds & Fruit eating & $\begin{array}{l}\text { Acokanthera schimperi (Murichoi / Lmurijoi/ } \\
\text { Murujoi/Lmorijoi) }\end{array}$ \\
\hline Monkeys & Seed eating & $\begin{array}{l}\text { Turraea parvifolia (Ltunturi / Njeniarok / Nchinioik), Rhus } \\
\text { natalensis (Msigioi / Lmisigiyioi / Lmisigiei) }\end{array}$ \\
\hline Browsers & Browsing & Celtis africana (Lekere / Lekiri / Ngisitet / Nekiri) \\
\hline
\end{tabular}

Table 13. Fodder and food for wildlife animals in Kirisia Forest, Samburu, 2005.

\section{Discussion}

\subsection{Demand side (forest utilization issues)}

\subsubsection{Kirisia Forest as source of water and dry season pasture and fodder}

The many non-wood uses of the forest offer great opportunities for benefit-sharing between the State and local communities as a component in participatory forest management. Tree species are harvested or damaged due to their value in human life: charcoal production, grazing, tree pollarding, honey harvesting, and logging for posts. The Kirisia forest is indeed one of the major water towers in the larger Samburu-Laikipia landscape. Data on water sources and associated drainage systems revealed a high number of dry riverbeds (45) indicative of the existence of many seasonal rivers. A few (15) permanent rivers and springs were found still flowing and there were several (17) water points and wells (highly frequented by people and the wild game mainly elephants and buffalo) and one swamp. Water resources are well distributed across the ecosystem.

\subsubsection{Harvesting of large sized trees}

Despite the presence of large-sized trees in the forest, Samburu community does not extract timber from the forest because it is illegal. Unauthorized splitting of cedar (Juniperus procera) posts for fencing and shelter construction was encountered in the forest, mainly close to settlements. Tree felling for charcoal production occurred in the Forest block nearest to Marallal town, Tamiyoi. Generally, these kinds of extractions were low but could lead to devastating consequences. Data indicated that, by and large, household economy for the 


\begin{tabular}{|c|c|c|c|c|c|c|c|c|}
\hline \multirow{2}{*}{$\begin{array}{l}\text { Species } \\
\text { Acokanthera sch. }\end{array}$} & \multirow{2}{*}{$\begin{array}{r}\text { Debarked } \\
1\end{array}$} & \multirow{2}{*}{$\begin{array}{r}\text { Death } \\
0 \\
0\end{array}$} & \multirow{2}{*}{$\begin{array}{r}\text { Defoliated } \\
0\end{array}$} & \multirow{2}{*}{ Injured } & $\begin{array}{l}\text { Total } \\
\text { W/L } \\
\text { damages }\end{array}$ & \multicolumn{3}{|c|}{$\begin{array}{cc}\% & \\
\text { damages } & \mathrm{W} / \mathrm{L} \\
\text { caused } & \text { damage } \\
\text { by } \mathrm{W} / \mathrm{L} & \text { share } \% \\
\text { All on each } & \text { among } \\
\text { damages species } & \text { species }\end{array}$} \\
\hline & & & & & 1 & 1 & 100 & 0.5 \\
\hline Celtis africana & 0 & 0 & ( & 0 & 1 & 2 & 50 & 0.5 \\
\hline Croton meg & 4 & 2 & ( & 0 & 9 & 13 & 69 & 4.5 \\
\hline Ekebergia cap. & 0 & 1 & ( & 0 & 1 & 1 & 100 & 0.5 \\
\hline Euclea sch. & 2 & 1 & ( & 0 & 6 & 15 & 40 & 3.0 \\
\hline Ficus thon. & 1 & 0 & & 1 & 2 & 5 & 40 & 1.0 \\
\hline Juniperus proc. & 62 & 26 & ( & 13 & 101 & 139 & 73 & 51.0 \\
\hline Lorekiri & 0 & 0 & & 1 & 1 & 1 & 100 & 0.5 \\
\hline Lkukut & 0 & 1 & ( & 0 & 1 & 1 & 100 & 0.5 \\
\hline Machakudu & 0 & 1 & ( & 0 & 1 & 2 & 50 & 0.5 \\
\hline Marrwet & 0 & 0 & ( & 0 & 1 & 1 & 100 & 0.5 \\
\hline Mystroxylon aeth. & 1 & 3 & & 1 & 5 & 5 & 100 & 2.5 \\
\hline Ngeni-Niok & 0 & 1 & ( & 0 & 1 & 1 & 100 & 0.5 \\
\hline Olea cap (hotch) & 1 & 0 & ( & 0 & 1 & 2 & 50 & 0.5 \\
\hline Olea europaea & 11 & 32 & & 13 & 57 & 269 & 21 & 28.8 \\
\hline Podofalc. & 3 & 0 & ( & 0 & 6 & 7 & 86 & 3.0 \\
\hline Teclea simpl. & 0 & 1 & ( & 0 & 3 & 10 & 30 & 1.5 \\
\hline Total & 86 & 69 & 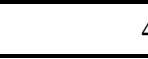 & 39 & 198 & 475 & 42 & 100.0 \\
\hline$\%$ WL damages & 43 & 35 & 2 & 20 & 100 & & & \\
\hline
\end{tabular}

Table 14. Types and magnitude of harm caused on woody plants by animals in Kirisia Forest, 2005.

\begin{tabular}{lrrrr}
\hline Blocks & $\begin{array}{r}\text { Sample Area } \\
(\mathrm{ha})\end{array}$ & $\begin{array}{r}\text { Area footpath/animal } \\
\text { trails }\left(\mathrm{m}^{2}\right)\end{array}$ & $\begin{array}{r}\text { Area trampled } \\
\left(\mathrm{m}^{2} / \mathrm{ha}\right)\end{array}$ & $\begin{array}{r}\text { \% surface area } \\
\text { trampled }\end{array}$ \\
\hline Rapar & 0.40 & 36.5 & 91.2 & 0.9 \\
Baawa & 0.76 & 157.9 & 207.8 & 2.1 \\
Tamiyoi & 0.78 & 45.0 & 57.7 & 0.6 \\
Nkorika & 0.50 & 90.2 & 180.4 & 1.8 \\
\hline Total & 2.44 & 329.6 & 135.1 & 1.4 \\
\hline
\end{tabular}

Table 15. Extent of footpath and animal trails in Kirisia Forest Reserve, Samburu - 2005. 
Samburu people is mainly based on land resource for cultivation and livestock keeping. However, the dependence of Samburu people on Kirisia is still high despite the increasingly changing lifestyle from pure pastoralism to mixed land uses. The forest plays a key role in livestock and agricultural development as a source of water and grazing land particularly during dry seasons.

\subsubsection{Fodder and food value}

Pollarding of Olea europaea (O. africana) was overwhelming throughout the forest with $62 \%$ of all damaged individuals being so through pollarding. Pollarding is manly done by harvesting the crown biomass by overtopping the tree for fodder, firewood, posts or all types of products. During drought or prolonged dry seasons, the herbaceous plants outside the forest disappear and grass dries up.

\subsubsection{Charcoal}

This sector needs to be carefully organised and controlled around the Kirisia Forest but not within the ecosystem itself. As reported by Girard (2002), zones of high concentration of commercial activities and those around urban centres are places with intensive utilisation of wood-fuel; and in such areas, there is an increasingly shifting from fuelwood to charcoal for domestic cooking and heating. High fuelwood and charcoal consumption coupled with weak supply sources put a lot of pressure on existing tree resources (mainly forest in such areas as Samburu where tree cover outside forest is low and manly preserved as shade trees or for fodder), resulting in severe climatic conditions. It is a fact that charcoal, more than fuelwood, is often produced from forest resources than scattered trees off-forests.

\subsubsection{Honey}

As source of income, honey prices per kilogramme were investigated per season for each household (MKK, 2005). Honey is domestically used but it is mainly produced for income generation. The average honey production was found to be $48 \mathrm{Kg}$ per year per beekeeping household; and on average the honey fetched Kenyan Shillings129 which is equivalent to US\$ 1.6 per kg. Total annual income from honey became Kenyan Shillings 6,192 (US\$ 77.4). The average net discounted income per household was Kenyan Shillings 3,301 (US\$ 41.2) (MKK, 2005). It is anticipated that this income would increase if improved techniques of apiculture and value addition were adopted and marketing strategies were put in place. Nevertheless, a lot of improvement is required to modernise the sector such as training to acquire new skills, use of improved equipment such as modern hives and harvesting gear.

\subsubsection{Medicinal value}

Different tree species have been mentioned by the local communities to treat different human ailments except in a few cases where a disease like malaria is treated using several species separately or through mixed concoction. A complete list of diseases based on this work and Watai and Gachathi (2003) for the same Forest includes:

1. Asthma (2 species)

2. Anemia (Blood shortage) (2 species)

3. Bone problem (1 species) 


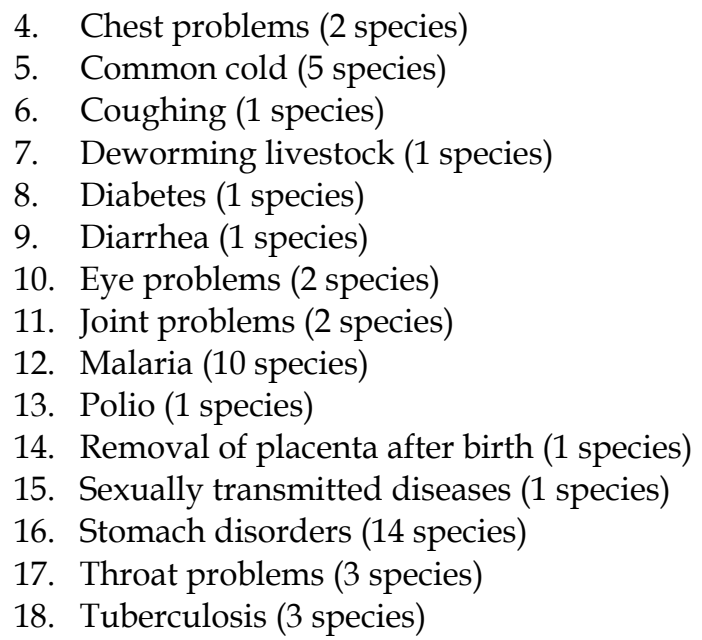

\subsection{Supply side (production issues)}

\subsubsection{Water sources and associated drainage systems}

The high number of dry riverbeds encountered during the survey showed that Kirisia Forest has many seasonal rivers. A few rivers were found still flowing. Several water points were also found and were highly frequented by wild game mainly elephants and buffalo. The Kirisia forest is indeed one of the major water towers in the larger Samburu-Laikipia landscape. Data on water sources and associated drainage systems revealed a high number of dry riverbeds (45) indicative of the existence of many seasonal rivers. A few (15) permanent rivers and springs were found still flowing and there were several (17) water points and wells (highly frequented by people and the wild game mainly elephants and buffalo) and one swamp. Water resources are well distributed across the ecosystem. Most of the forest products are harvested for household consumption (Figure 7); hence the community does not view the forest as a source of income as much as the source of sustenance. For instance, the public forest is the major source of firewood and construction and fencing posts; most of which being used for subsistence (Figure 8).

\subsubsection{Ecotourism}

The forest has very high potential for ecotourism development owing to its high richness and diversity in wildlife and other scenic, physical features. Major wildlife corridors and eco-tourism attractions in Kirisia Forest were recorded and documented with GIS Database at AWF. In all blocks, high variability in vegetation cover from herb layer to forest tree canopy led to high diversity of habitat for animal life. The entire forest ecosystem is unique and an integral conservation strategy is required for sustained biodiversity conservation. The mapping out and protection of critical micro-habitats for diversity conservation would assist in the management of ecotourism in this forest. It is quite important to safeguard the integrity of Kirisia forest also owing to its important catchment value in the region. The Kirisia forest richness in medicinal plants and bee forage is already being positively exploited by local people despite some policy challenges such as lack of clear national policy incentives for herbal medicine. However, with the Forest Act 2005 encourages local communities to participate in the management of State and Local Authority forests through 
Community Forest Associations. Structured bee keeping and herbal medicine activities can therefore form good entry points to forge a Government-Local people partnership in conserving Kirisia Forest. Other eco-friendly enterprises that would be promoted include camping sites, afforestation of degraded areas, organised commercial tree seed collection from economically important tree species such as Croton megalocarpus (e.g. for timber and biodiesel) and Olea europaea and Podocarpus species (for timber) and other species that Kenya Forest Seed Centre of the Kenya Forestry Research Institute may be interested in. Other local and international bodies dealing with tree genetic resources may also finance the collection and preservation of germplasms of threatened species and those of high medicinal values once they are identified.

\subsubsection{Forest as habitat to wildlife and attraction for eco-tourism development}

Both species, Juniperus procera and Olea europaea ssp africana seriously damaged by wildife, dominate the upper canopy of the forest and their depletion is a major threat to the Kirisia ecosystem. There is high diversity of birds and animals due to different habitat types within the Kirisia forest. Though no snake was seen during the survey, local guides testified that both large and small snakes, poisonous and non-poisonous do exist in the forest. For example, during this survey, a long Cobra (over $1 \mathrm{~m}$ long) was shot dead by KWS rangers at their Camp next to Baawa block. In this study it was difficult to determine endemic forest species (animals and birds). However, the overwhelmingly high diversity of birds' populations showed the need to conserve the Kirisia Forest Reserve as a critical habitat for birds hence making it one of the Important Bird Area (IBA) in the country.

\subsubsection{Kirisia Forest as source of wood}

Out of the 95 tree species, 47 (i.e. $49 \%$ ) were recorded in the timber-sized stage; an indication that a good number of tree species in the Kirisia forest can reach large diameters at maturity. However, only 33 tree species out of the $47(14 \%)$ were represented in the pole-size category. Their populations were on decline, particularly Juniperus procera population. The ageing and declining J. procera population paved way to other species like Teclea simplicifolia. Juniperus procera's high representation at Tamiyoi in the pole stage may be as a result of high fire incidence which may have favoured the J. procera regeneration as a pioneer species, whose seed dormancy is broken by heat. The density of seedlings and saplings varied among the four blocks; it was satisfactory at Rapar and Baawa but very low in Tamiyoi and Nkorika. Logging in natural forests is not the primary management objective in Kenya. If introduced, it would be very destructive and unsustainable in Kirisia forest. Few species dominate in the upper canopy and all produce high quality timber with established markets both locally, nationally and internationally. Logging in the forest would target the same species and destroy the forest structure, leading to destabilization of the ecosystem. Suffice to note the regeneration level of the upper canopy species is very low (Hitimana et al., 2009). However, the growth of trees to huge sizes as observed in this dry forest was a revelation of hope in forestry. On average, the number of timber-sized trees and basal area per unit area reflected a productivity value slightly higher than that recorded in the Mt Elgon Lower Montane Forest (Hitimana et al, 2004) with similar elevation range. The highest density (108 trees / ha) and basal area (32 $\mathrm{m}^{2} / \mathrm{ha}$ ) recorded in Nkorika Block was comparable to that of the most productive site found at Mt Elgon and South Nandi forests in high potential areas of western forest region of Kenya (Hitimana et al., 2004; Njunge, 1996). These forests however 
suffered much more stiff commercial logging activities in the past than Kirisia but less wildlife damage. Nevertheless, the data showed that plantation forestry as a land use is feasible on the Kirisia site particularly on communal land adjacent to the forest and similar environments as long as well adapted tree species or varieties are used and adequate protection of trees against animals, fire, pollarding and illegal tree cutting is provided. Kenya Forestry Research Institute and other competent institutions such as universities are encouraged to enhance plantation forestry research in such low rainfall areas. At the same time, local communities should be sensitized to embrace integrated land use planning and set aside land (private or communal) for tree planting targeting useful products. The success of tree planting activities would reduce human pressure on the Kirisia ecosystem by providing a buffer and would enhance environmental services such as soil and water conservation, carbon sequestration, and climate regulation in the area.

\subsubsection{Beekeeping, honey hunting and food products}

The Kirisia State Forest is a major habitat for bees and a main source of honey for the locals either from beehives hangs in the forest or from wild honey obtained from colonized tree hollows, rocks etc. The purchased honey also originates from the forest. The role and potential of Kirisia forest as critical source of nectar, water makes an ideal site for hive placement. Most households locate their hives in their homestead but others locate them in/on the border of the forest even though the State outlaws it (MKK, 2005). Once the Forest Act 2005 is fully implemented, such activity will be legalised and well coordinated. The percentage of hives in the forest will definitely increase significantly. The use of Kirisia forest as source of food was revealed by the high number of species reported to produce edible fruits. They are mostly relied on by shepherds or households during famine periods. According to Falconer and Arnold (1989), the role of trees in food security occurs in several ways: supplementing farm production, filling in seasonal shortfalls in food and income, providing a buffer during hardship periods, and income earned from forest-based activities which are sometimes invested in agricultural assets such as livestock. A well managed forest offers the poor a means for investment in their future; an opportunity to escape or break from the cycle of poverty.

\subsubsection{Medicinal value}

The medicinal value of the Kirisia forest to local communities is immense. Statistics provided by this study are just indicators of a huge potential and reveal the need for further investigations in Non-timber forest products from the forest. Specifically, for herbal medicine, many resources exist in non-woody and climbing plants that were not covered in this survey. To illustrate this, 45 species out of 65 (that is, 69\%) reported in Watai and Gachathi (2003) as having medicinal value were not recorded in this study. Different parts of the plant are used: Bark (9 species), Fruits (1 species), Leaves (8 species), Roots (28 species), and Stem (8 species). The medicinal value of the Kirisia forest is very high. Different types of diseases are treated using extracts from roots, stems, fruits, leaves and bark. Similar observations were earlier made by Watai and Gachathi (2003).

In summary, the Kirisia Forest is a valuable extension of adjacent communities' natural resource base. They extract fuelwood, grazing, wood for fencing and construction, water resources for domestic use and livestock, harvesting wild honey, collecting medicinal plants, and wild fruits. Nearly all natural forests offer similar functions (e.g. Odhiambo, 2005; Kiruki, 2000) but the degrees of dependence vary among climatic zones. Communities in 
less humid areas depend much more on non-wood forest products from natural vegetation than those in high potential areas where there are more diverse economic activities.

\subsection{Regulating natural resource use: Management issues 4.3.1 Empowering local communities}

Communities adjacent to Kirisia Forest are heavily dependent on the forest, but the current levels of exploitation are not sustainable. There is need to develop sustainable management systems which involve participation of locals and other stakeholders. The pastoralists in Kenya are usually associated with savannah and grassland ecosystems but in times of climate change and growing poverty, the Kirisia forest shows that dryland forests play a unique role in sustaining pastoralists' livelihoods. Being in a relatively dry area and surrounded by a pastoral community, water and dry season grazing emerged to be very important products to the community. However, there is need to enhance education system in the area for human resources development and community empowerment in joint forest management. Currently, levels of literacy are very low around Kirisia forest. High literacy levels would enhance access to information, negotiation skills and records keeping which are key to sustainable natural resource management and catalyze speedy improvement of livelihoods. Communities around the forest must be empowered in tree planting around settlements as they progressively shift from nomadic to sedentary life in order to reduce heavy reliance on natural forest timber as construction materials. They should also be empowered to venture into eco-friendly enterprises and to add value to their products.

\subsubsection{Conflict management and damage control}

People around the Kirisia Forest have been in conflicts with wild animals over mainly predation on livestock, damage to agricultural crops outside the forest and transmission of diseases to livestock. Rare cases of human deaths caused by hostile wild animals were also mentioned. Listed unfriendly animals include elephants, hyena, leopards, lions, poisonous snakes, ticks, tsetse flies and water-borne pests / parasites. The fact that livestock grazing in large numbers in Kenya's natural forests is the cause of much damage to natural vegetation particularly regeneration through browsing and trampling was also observed by Kiama and Butvnski (1999). Even in high potential areas where fodder is grown outside the forest, the production is in most case insufficient and the nearby forest is relied upon (Odhiambo, 2005). Communities that surround the forest made negatively impact on the ecosystem through dry season grazing, forest fires, tree felling for honey harvesting, human encroachment for settlement, intensive exploitation of posts. The threats to good forest health that were encountered in the forest included debarking, defoliation, damage by fire, physical injuries to trees, dead trees, dying trees, fallen trees due to animals or wind, diseases, suppression, destructive honey harvesting, game damage such as elephant browsing, elephant debarking, and boring insect. Professional management practices can potentially mitigate majority of the damages. Major destructive agents in Kirisia forest were elephants and buffalos and man through grazing, fodder, trampling, honey hunting and fire. Forest degradation through trampling was high due to high number of grazing animals in the forest, both domestic and wild. The disturbance on trees in Kirisia Forest mainly affected two commercial species Olea africana and Juniperus procera across all the study sites. Unless specific measures are found to conserve these species, their relative importance is 
significantly declining and the destruction of the forest upper canopy will soon destabilize the entire ecosystem. Disturbance resulting from fodder scarcity and pasture degradation will be avoided by developing adequate sources of fodder and management of pastures outside the forest, either on private or communal land coupled with de-stocking and keeping manageable sizes of livestock herds. Improved grazing systems and beekeeping technologies will assist to control forest fires to a great extent.

\subsubsection{Medicinal plants, water and ecotourism development}

As much as possible, it is important to minimise the harvesting of bark, roots and stems or develop low impact harvesting techniques to ensure targeted species are not depleted. Other conservation and protection measures are: species domestication and demarcation of core conservation areas. There is also need to carry out thorough taxonomic and toxicological studies on medicinal plants in the region. Nevertheless, it is quite clear that conserving plant diversity in Kirisia is synonymous to conserving medicine and promoting people's health now and in the future. Household economic study on herbal medicine to gauge its impact on people's welfare is equally needed, e.g. determine how much savings compared to using alternative modern medicine. Training and technological innovations for value addition and quality assurance of herbal medicine would also enhance conservation and improve income generation. Water sources must be protected using proven technologies. To enhance ecotourism initiatives, mechanisms for un-skewed sharing of benefits must be put in place within the joint forest management framework.

\subsubsection{Management and conservation options: Participatory and landscape models}

Poor or lack of pasture management strategies / plan in Group Ranches, water scarcity due to erratic rainfall and overstocking contribute to pasture degradation and scarcity of pasture and fodder outside the forest during dry seasons. Due to its forest microclimate, Kirisia forest ecosystem is the only recourse to pastoralists from nearby Group Ranches during such critical seasons of water and fodder crisis. Fodder supply is a very important and critical socioeconomic role of the forest for the Samburu pastoralist community. It is therefore fitting to develop sustainable fodder utilization plan which would promote diversification of species harvested based on the existing supply and guide the regeneration of affected resource species to ensure sustainability. The plan would explore different silvopastoralism technologies and recommend sustainable management of pastures within and outside the forestland. Pasture and fodder management is an attractive entry for joint management of Kirisia Forest between Group Ranches surrounding the forest and the State represented by Kenya Forest Service. Due to the critical function of the forest as a unique habitat to wildlife within the landscape, the Kenya Wildlife Service is an inevitable third stakeholder to include in this scheme of joint management of the Kirisia. Conservation of Kirisia forest is very critical to livelihood of beekeepers and other honey users around the forest. A refinery has now been constructed through the help of AWF and technical support from the International Centre for Insect Physiology and Ecology (ICIPE). It is run by a local beekeeping cooperative. Through this initiative, extracted honey is of certified quality, well packaged and sold to markets outside the production region. In addition, other products like beeswax and sting are produced. The refinery is promoting off-farm employment to some cooperative members. Based on honey harvesting results and associated damages, it is important to continue promoting beekeeping outside the forest and ecologically safer 
methods of honey collection. These initiatives would significantly contribute to the conservation of the forest and its resources therein and enhance the socioeconomic value of the forest for current and future generations. As stated by FAO (1993), banning the production and or marketing of charcoal has proved counterproductive: "bans do not reduce production but drive producers to underground, thereby precluding proper control of production procedures". The best option is to manage this charcoal sector in a sustainable, environmentally-friendly manner as follows (Girard, 2002):

- Encourage widespread use of well designed energy-efficient charcoal stoves,

- Promote tree planting outside the Kirisia Forest Reserve with quality energy species

- Introduce proper forest management practices and regulations based on the biological potential of affected species to regenerate,

- Encourage diversification of species used; promote fast-growing even if they produce less dense charcoal; market them on weight- rather than volume-bases

- $\quad$ Produce technologies to produce more charcoal using less wood

- Encourage local communities to use other sources of fuel e.g. bio-gas, solar energy.

- Encourage actors in charcoal production-marketing chain to be organised in registered groups once the Charcoal policy Paper in Kenya is put in place.

Sustainable production and use of charcoal can have a significant impact by helping to conserve resources, reducing massive migrants from rural or forested areas to urban or commercial centres and by improving people's incomes (Girard, 2002).

\section{Conclusion and recommendations}

Kirisia Forest is of great ecological, social and economic importance to the surrounding communities. Threats facing the Kirisia forest and its constituent resources are mainly anthropogenic and can be effectively addressed through joint effort between the State, local Communities and other stakeholders. There is need to urgently initiate, develop and implement a sustainable forest management plan embracing the participatory approach. At the same time, it is critical for the community to develop community-based natural resources management plans to optimise utilization and ensure sustainability of locally available resources in Group Ranches. This will minimise direct dependence on the forest and mitigate potential conflicts. Areas with highest focus in developing the joint management model should include: herbal medicine, beekeeping, wildlife conservation and ecotourism (nature-based enterprises), charcoal use and production outside the forest (i.e. in Group Ranches and consumption Centres), pasture management and animal husbandry. Providing alternative options to destructive consumptive uses of forest resources would minimize major threats to the ecosystem.

\section{Acknowledgements}

Authors acknowledge the financial support from African Wildlife Foundation (AWF), The Royal Government of Netherlands and USAID. We also appreciate the administrative support from the Forest Department (now KFS), Samburu District. Special thanks go to the field teams during data collections and to the AWF GIS Experts for their professional input during the planning of field visits and production of resource maps thereafter. We sincerely thank the Samburu Community in Mbaringon, Lkiloriti (Baawa), Ledero and Lodokejek for their support and cooperation. 


\title{
7. Appendices
}

\section{Appendix A: Checklist of animal life in the Kirisia Forest ecosystem, Samburu, Kenya, 2005}

\author{
Wild animals \\ Sign of presence \\ Aardvark \\ Holes and physical presence \\ Ants \\ Physical presence on plants, anthills \\ Baboon \\ Skull, physical presence, sound, foot marks \\ Bees \\ Physical presence, trace of honey harvesting on felled trees (Juniperus \\ procera, Croton megalocarpus, Podocarpus sp, Olea capensis ssp \\ hotchestetteri \\ Buffalo \\ Physical presence, carcasses (bone, skull, teeth), fresh dung, foot \\ marks, drinking points, resting grounds, droppings, trails, grazing \\ areas, hair on tree trunks, \\ Bush pig / Wild pig Feaces, foot marks \\ Bushbuck \\ Physical presence, Foot marks, salt points, sleeping place, freshly \\ killed animal \\ Butterflies \\ Physical presence \\ Dik dik \\ Foot print \\ Eland \\ Physical presence, foot marks \\ Elephant \\ Physical presence, bathing points, types of damages on trees e.g. \\ Debarking, carcasses (bones, skull), resting places, trails, droppings, \\ foot marks, play ground, salt points, \\ Gazelle \\ Physical presence, fresh urine, feaces, salt point \\ Hyena \\ Foot marks \\ Kelly frankolin \\ Physical presence \\ Leopard \\ Foot marks, freshly killed prey by a leopard, skull \\ Lintutal \\ Physical presence \\ Lion \\ Foot mark \\ Porcupine \\ Quills (i.e. Spikes) \\ Safari ants \\ Physical presence \\ Tree Squirrel \\ Physical presence \\ Warthog \\ Foot marks, brushing point, ground scratches, droppings, sleeping \\ place, skull, \\ Waterbuck \\ Foot marks, resting place, trails \\ Zebra \\ Sound, dung / droppings
}


Appendix B: Key bird species recorded from Kirisia Forest (Oct-Nov 2005) and their preferred habitat types

\begin{tabular}{|c|c|c|}
\hline Common names & $\begin{array}{l}\text { Scientific names } \\
\text { (Samburu names) }\end{array}$ & Preferred habitat types \\
\hline $\begin{array}{l}\text { 1. (African) Paradise } \\
\text { Flycatcher }\end{array}$ & Terpsiphone viridis & Widespread, locally common. \\
\hline $\begin{array}{l}\text { 2. (Nominate) Baglafecht } \\
\text { Weaver (- allied to } \\
\text { Reichenow's weaver (P. } \\
\text { baglafecht reichenowi) }\end{array}$ & Ploceus sp & $\begin{array}{l}\text { Moorland bush, forest margins, } \\
\text { grass and scrub, highlands of } \\
\text { Kenya }\end{array}$ \\
\hline $\begin{array}{l}\text { 3. (White?) Yellow Throated } \\
\text { Nicator }\end{array}$ & Nicator vireo & \\
\hline 4. Abyssinian Crimsonwing & Cryptospiza salvadorii & $\begin{array}{l}\text { Undergrowth of forests and } \\
\text { bamboo }\end{array}$ \\
\hline $\begin{array}{l}\text { 5. Abyssinian Ground } \\
\text { Thrush }\end{array}$ & Turdus piaggiae & $\begin{array}{l}\text { Lush bush, margins of forests and } \\
\text { lush grass near water }\end{array}$ \\
\hline 6. African Dusky Flycatcher & Alseonax adustus & Wooded and Forest areas \\
\hline $\begin{array}{l}\text { 7. African Little Sparrow } \\
\text { Hawk }\end{array}$ & $\begin{array}{l}\text { Accipiter minullus } \\
\text { (Lonya Kweny) }\end{array}$ & $\begin{array}{l}\text { Woodland and forest hawk; } \\
\text { uncommon and local } \\
\text { (Endemic to woodlands and } \\
\text { forests). }\end{array}$ \\
\hline 8. Augur Buzzard & $\begin{array}{l}\text { Buteo rufofuscus } \\
\text { (Lmagiro) }\end{array}$ & Forest glades \\
\hline 9. Barbet & (Lodidioi) & $* * * *$ \\
\hline $\begin{array}{l}\text { 10. Black Fronted Bush } \\
\text { Shrike }\end{array}$ & Malaconotus migrifrons & High level forests \\
\hline 11. Black Kite & Milvus migrans & $\begin{array}{l}\text { Resident and local migrant; } \\
\text { savannah and open country }\end{array}$ \\
\hline 12. Black-Headed Oriole & $\begin{array}{l}\text { Oriolus larvatus } \\
\text { (Lkirapach / Lpolpol) }\end{array}$ & $\begin{array}{l}\text { Partial migrant of open woodland, } \\
\text { scrub, highland forests, coastal } \\
\text { bush }\end{array}$ \\
\hline 13. Blue capped Cordon-Bleu & $\begin{array}{l}\text { Uraeginthus } \\
\text { cyanocephalus } \\
\text { (Ntaidi-idi) }\end{array}$ & Dry bush, less common. \\
\hline $\begin{array}{l}\text { 14. Brown-Headed } \\
\text { (crowned) Tchagra }\end{array}$ & $\begin{array}{l}\text { Tchagra australis } \\
\text { (Lomerei) }\end{array}$ & Scrub, woodland, undergrowth \\
\hline
\end{tabular}




\begin{tabular}{|c|c|c|}
\hline Common names & $\begin{array}{l}\text { Scientific names } \\
\text { (Samburu names) }\end{array}$ & Preferred habitat types \\
\hline $\begin{array}{l}\text { 15. Cinnamon Bracken } \\
\text { Warbler }\end{array}$ & $\begin{array}{l}\text { Bradypterus } \\
\text { cinnamomeus }\end{array}$ & $\begin{array}{l}\text { In or near mountain forests, } \\
\text { at } 3800 \mathrm{~m} \text { a.s.l and above, } \\
\text { In thick tangled undergrowth, } \\
\text { bush, bracken and bamboo. }\end{array}$ \\
\hline 16. Collarded Sunbird & $\begin{array}{l}\text { Anthreptes collaris } \\
(\mathrm{Njim})\end{array}$ & $\begin{array}{l}\text { Forests, woodland, scrub and } \\
\text { bushes }\end{array}$ \\
\hline $\begin{array}{l}\text { 17. Common (Namaqua) } \\
\text { Dove }\end{array}$ & $\begin{array}{l}\text { Oena capensis } \\
\text { (Nkutukurnk) }\end{array}$ & $\begin{array}{l}\text { Arid and Semi-desert bush country, } \\
\text { Acacia stands especially in sandy } \\
\text { areas and } \\
\text { open dry woodlands }\end{array}$ \\
\hline 18. Common Bulbul & (Nkirokie) & $* * * *$ \\
\hline 19. Fan-Tail Raven & Corvus rhipidurus & $\begin{array}{l}\text { Rocky hill country and near camps } \\
\text { and } \\
\text { human habitations as a scavenger }\end{array}$ \\
\hline 20. Green Backet Twinspot & Mandingoa nitidula & $\begin{array}{l}\text { Dense undergrowth of forests, } \\
\text { thickets and heavy vegetation } \\
\text { along streams. }\end{array}$ \\
\hline 21. Grey Apalis & Apalis cinerea & Forest tree top and undergrowth \\
\hline $\begin{array}{l}\text { 22. Grey Backed } \\
\text { Camaroptera }\end{array}$ & $\begin{array}{l}\text { Camaroptera } \\
\text { brevicaudata } \\
\text { (Nakudel) }\end{array}$ & $\begin{array}{l}\text { In both highland and lowland } \\
\text { forests, } \\
\text { wooded and scrub vegetation }\end{array}$ \\
\hline 23. Grey Cockoo Shrike & Coracina caesia & Evergreen mountain forests \\
\hline 24. Grey Parrott & Psittacus erithacus & In flocks; in tops of forest trees \\
\hline 25. Hartlaub's Turaco & $\begin{array}{l}\text { Tauraco hartlaubi } \\
\text { (Ngewa) }\end{array}$ & $\begin{array}{l}\text { Highland forests; common in } \\
\text { forests } \\
\text { around Nairobi }\end{array}$ \\
\hline 26. Lemon Dove & Aplopelia larvata & $\begin{array}{l}\text { Shy, sensitive bird, largely on the } \\
\text { ground. }\end{array}$ \\
\hline 27. Lesser Honey Guide & $\begin{array}{l}\text { Indicator minor } \\
\text { (Nchochoroi) }\end{array}$ & $\begin{array}{l}\text { A variety of habitats from forests to } \\
\text { woodlands. }\end{array}$ \\
\hline $\begin{array}{l}\text { 28. Long-Tailed Fiscal } \\
\text { (Shrike) }\end{array}$ & $\begin{array}{l}\text { Lanius cabanisi } \\
\text { (Lkerekitag) }\end{array}$ & $\begin{array}{l}\text { In coastal area of Kenya and on } \\
\text { the Athi plains }\end{array}$ \\
\hline $\begin{array}{l}\text { 29. Northen Double } \\
\text { Collarded Sunbird }\end{array}$ & Nectarinia preussi & Mountain forests in Kenya \\
\hline
\end{tabular}




\section{Appendix B (Continued)}

\begin{tabular}{|c|c|c|}
\hline Common names & $\begin{array}{l}\text { Scientific names } \\
\text { (Samburu names) }\end{array}$ & Preferred habitat types \\
\hline 1. Nubian Wood Pecker & $\begin{array}{l}\text { Campethera nubica } \\
\text { (Ltilo) }\end{array}$ & $\begin{array}{l}\text { Open bush, Acacia woodland, } \\
\text { often common }\end{array}$ \\
\hline 2. Olive Thrush & Turdus olivaceus & $* * * *$ \\
\hline 3. Robin Chat & Cassypha caffra & $\begin{array}{l}\text { Widespread, mostly above } 1530 \mathrm{~m} \\
\text { a.s.l., } \\
\text { forests, wooded and scrub areas }\end{array}$ \\
\hline $\begin{array}{l}\text { 4. Rossy Patched Bush } \\
\text { Shrike }\end{array}$ & (Losir-Monyaa) & Tree top foliage \\
\hline 5. Scaly Francolin & $\begin{array}{l}\text { Francoline squamatus } \\
\text { (Lkurle lentim) }\end{array}$ & $\begin{array}{l}\text { Forests, thick bush near forests, } \\
\text { Kenya highlands; A local bird, } \\
\text { absent from many apparently } \\
\text { suitable } \\
\text { localities }\end{array}$ \\
\hline $\begin{array}{l}\text { 6. Slivery-Cheeked } \\
\text { Hornbill }\end{array}$ & Bycanistes brevis & $\begin{array}{l}\text { Mainly a forest species; } \\
\text { many in Kenya coastal forests }\end{array}$ \\
\hline 7. Sooty Ant Eater & & $* * * *$ \\
\hline 8. Speckled Mousebird & $\begin{array}{l}\text { Colius striatus } \\
\text { (Lmodooni) }\end{array}$ & $\begin{array}{l}\text { Forested and wooded areas, } \\
\text { dense scrub; destructive to growing } \\
\text { vegetables and fruit trees }\end{array}$ \\
\hline 9. Square-Tailed Drongo & $\begin{array}{l}\text { Dicrurus ludwigii } \\
\text { (Lkurdudu) }\end{array}$ & $\begin{array}{l}\text { Forests, dense woodland, } \\
\text { most frequent in western Kenya }\end{array}$ \\
\hline \multicolumn{3}{|l|}{ 10. Squirrel } \\
\hline 11. Streaky Seed-eater & Serinus striolatus & \\
\hline 12. Superb Starlling & $\begin{array}{l}\text { Spreo superbus } \\
\text { (Surpelei) }\end{array}$ & $\begin{array}{l}\text { Widespread resident and partial } \\
\text { migrant. Thorn bush, Acacia } \\
\text { vegetation and near human } \\
\text { settlements. }\end{array}$ \\
\hline 13. Tropical Boubou & $\begin{array}{l}\text { Laniarius ferrugineus } \\
\text { (Lmongo Lwaas) }\end{array}$ & $\begin{array}{l}\text { Thick cover in forests, woodland, } \\
\text { riverine thickets, bush }\end{array}$ \\
\hline $\begin{array}{l}\text { 14. White (Stared) } \\
\text { Throated Robbin }\end{array}$ & Irania gritturalis & $\begin{array}{l}\text { Dense scrub, along dry riverbeds, } \\
\text { Winter visitor from Asia }\end{array}$ \\
\hline
\end{tabular}




\begin{tabular}{|c|c|c|c|}
\hline & $\begin{array}{l}\text { White Eyed Slaty } \\
\text { Flycatcher }\end{array}$ & Dioptrornis fischeri & Highland forest, forest margins. \\
\hline 16. & Yellow White Eye $* * * *$ & & $* * * *$ \\
\hline & $\begin{array}{l}\text { Yellow-Whiskered } \\
\text { Greenbul }\end{array}$ & Andropadus latirostris & $\begin{array}{l}\text { Eastern Kenya Highlands and } \\
\text { western Kenya }\end{array}$ \\
\hline
\end{tabular}

Source: Field Survey (Oct - November 2005), identification by Robert Rosano Lentareia (Field guide) and edited based on Williams and Arlott (1985) - A Field Guide to the Birds of East Africa.

\section{References}

Eckersley, R. (1992). Environmentalism and political theory: Towards an ecocentric approach. London University College, London Press.

Falconer, J. and Arnold, J.E.M. (1989). Household food security and forestry: an analysis of socioeconomic issues. Community Forestry Note 1, FAO, Rome.

FAO (1993). A decade of wood energy activities within the Nairobi Programme of Action. FAO Forestry Paper No. 63, Rome.

Girard, P. (2002). Charcoal production and use in Africa: what future? Unasylva, 53 (211): 30-34.

Gow, D.D. (1992). Forestry for sustainable development: the social dimension. Unasylva 43 (169). www.fao/org/forestry/unasylva.stm

Hitimana , J., Kiyiapi, J., Kisioh, H., Warinwa, F., Lenaiyasa, P., Mayienda, R., and Daudi Sumba, D. (2009). Participatory ecological assessment of Kirisia forest reserve, samburu, Kenya. AWF Technical Paper Series, African Wildlife Foundation, Nairobi.

Hitimana, J., Kiyiapi, J.L., Njunge, J.T. (2004). Forest structure characteristics in disturbed and undisturbed sites of Mt. Elgon Moist Lower Montane Forest, western Kenya. Forest Ecology \& Management 194: 269-291.

Ikua, W. \& Sommerlatte, M. (2007). A Tourism Strategy For Samburu District (Final Report). Commissioned By The African Wildlife Foundation With Support From Tourism Trust Fund.

Jaetzold, R. \& Schmidt, H. (1983). Farm management Handbook vol II- Natural conditions and Farm management information, Part B Central Kenya (Rift Valley and Central Provinces). Ministry of Agriculture, Kenya, in cooperation with the German Agricultural Team (GAT) of the GTZ, Nairobi

Kiama, D. and Butynski, T.M. (1999). Distribution and abundance of trees in the Aberdares ecosystem, Kenya. In: Butynski, T.M.: Aberdares National Park and Aberdares Forest Reserves Wildlife fence placement study and recommendations. A report for the Kenya Wildlife Service and the Kenya Forestry Department. Zoo Atlanta's Africa Conservation Program. Appendix II.

Kiruki, H. M. (2000). A review of the state of community forestry in Kenya. A report presented to Forest Action Network, September 2000.

MKK (2005). Kirisia Forest Beekeepers : A Baseline Study. Draft Report. Mkk Ltd.

Njunge, T.J., (1996). Species composition and regeneration of South Nandi Forest. PhD Thesis. University of Wales, UK. 
Odhiambo, J.M. (2005). Forest utilization by adjacent communities: a case study of kiandogoro Forest in the Aberdares Region, Kenya. MPhil Thesis, Moi University, Eldoret, Kenya.

Republic of Kenya (2005). The Forests Act 2005. Kenya Gazette Supplement No. 88 (Acts No. 7); The Government Printers, Nairobi.

Watai, M.K. and Gachathi, F.N. (2003). Conservation for Sustainable Utilization of Biodiversity through enhanced access and Benefit Sharing with Forest adjacent Communities in Kirisia Forest Samburu District. Report for African Wildlife Foundation, Samburu Heartland

Whittaker, R.H.(1975). Communities and Ecosystems. 2nd Ed., McMil. Pub., New York. 


\title{
People, Parks and Poverty: Integrated Conservation and Development Initiatives in the Free State Province of South Africa
}

\author{
André Pelser, Nola Redelinghuys and Nontombi Velelo \\ Department of Sociology, University of the Free State \\ South Africa
}

\section{Introduction}

Conservation policy and practices over the past few decades have strongly emphasised the linkages between rural poverty and environmental degradation and, more specifically, the importance of reconciling the socio-economic needs and expectations of local communities with the objectives of biodiversity conservation and protected-areas management. Several international agencies and organisations, including the World Bank, World Wide Fund for Nature, The World Conservation Union, USAID and United Nations agencies, have come out in support of the idea that biodiversity-conservation programmes should take into account the socio-economic needs of the local population. Protected areas are thus increasingly expected to cross the boundaries of conventional biodiversity protection and take their place on the national development agenda by contributing to poverty reduction among rural communities adjacent to parks and reserves. In fact, over the past two decades or more, there has been growing recognition in conservation circles that national parks and other protected areas cannot be managed successfully without consideration for the subsistence and economic requirements of their neighbouring communities (Hulme \& Murphree, 2001; Kothari et al., 1998; Naughton-Treves, 2005; World Parks Congress, 2003). With world leaders and development agencies increasingly coming out in support of poverty-alleviation initiatives, and the Millennium Development Goals - particularly the first of the eight goals - that aim to curb poverty significantly by 2015, it is important to understand and assess the role that protected areas may potentially play in this endeavour. This chapter explores one example of how a national park in the Free State Province of South Africa has reached out to its neighbouring communities in an attempt to channel conservation benefits to the local people and thereby to address some of the developmental needs of the population in the surrounding areas. More specifically, the chapter distils some of the key findings and lessons derived from a poverty-alleviation project at the Golden Gate Highlands National Park - a project that operates under the banner of the People and Parks Programme of South African National Parks (SANParks) and attempts to involve neighbouring communities in the conservation of biodiversity in a mutually beneficial fashion. The People and Parks Programme embodies the new policy framework of conservation authorities in South Africa - a policy that represents a significant change in philosophy from the conventional protectionist and fortress approach to conservation. In 
order to appreciate the context of this policy, we need briefly to trace the origins of the current approach to integrated conservation and development initiatives.

\section{People or/and protected areas: From strict reservation to cautious integration}

The concept of a "protected area" was coined in the late 1800s in response to growing concern at the loss of wilderness areas. Although The World Conservation Union distinguishes six different categories of protected areas (Harmon, 1994), the term is now commonly used as an umbrella concept so as collectively to include national parks, biosphere reserves, nature reserves and marine protected areas. The majority of protected areas are located in rural environments with the primary purpose of protecting biodiversity. Yet such areas may also include a range of important social, cultural and economic functions (Dudley et al., 2008).

Since the proclamation of the very first national park in the world, official approaches to conservation had, almost without exception, concentrated on protecting the ecological biodiversity inside a demarcated and fenced area. This was achieved by segregating the local population from the protected area and preventing the utilisation of biodiversity inside the proclaimed park or reserve (Algotsson, 2006). Local communities have traditionally been fenced out from such protected areas and have, in some instances, even been forcibly relocated for the sake of conservation. Some estimates set the total number of people worldwide who have been displaced as a result of the establishment of protected areas at more than ten million (Dudley et al., 2008). The main focus of protected areas fell on the conservation of biological biodiversity, the demarcation of boundaries and the provision of tourist facilities, with little consideration for the influence of these areas on the livelihoods of (often poor) local communities. The same approach to conservation was adopted by authorities in Southern Africa, where local communities were seldom consulted in the establishment of protected areas (Fabricius et al., 2001). This approach - fostered by the rapid expansion of protected areas during the second half of the twentieth century - often conflicted with the developmental needs of rural populations in developing countries.

Protected areas worldwide have increased more than tenfold in respect of total coverage since 1980 (Zimmerer et al., 2004). During the period 1900-1949, there were fewer than 600 officially protected areas worldwide (Pelser \& Sempe, 2003), but this figure has increased exponentially over the past three decades. The campaign to increase the proportion of protected areas significantly was first seriously promoted at the 1982 World Parks Congress in Bali, where all nations were set a target of having $10 \%$ of countries under protection (Naughton-Treves, 2005). At the World Parks Congress in 2003, it was reported that the number of protected areas had tripled over the preceding 20 years bringing the total to an estimated 100000 worldwide (World Parks Congress, 2003), although some put the current figure at more than 105000 (Upton et al., 2008). The impact of these expanding protected areas on the livelihoods of neighbouring communities, has however largely been ignored by conservation authorities.

The continuous expansion and proclamation of protected areas for the exclusive protection of scenic areas of biodiversity became increasingly ill suited to the socio-economic realities of the developing world and tended to conflict with both the existing resource-use and livelihood practices of local peoples (Ghimire, 1995). Conservation authorities in Africa and elsewhere soon realised that "protection" and "development" were not necessarily mutually 
exclusive concepts; in fact, the successful management of most protected areas became irreversibly intertwined with the provision of benefits to and the cooperation of rural communities. More specifically, the expansion of large protected areas, such as national parks, is today increasingly confronted with the reality of rural communities stricken with dire poverty - communities who are often entirely dependent for their survival on the very resources that have now been proclaimed "protected". As, internationally, both the debate around sustainable development and the need for conservation approaches to take into consideration not only socio-economic but also environmental aspects gained momentum (Spenceley, 2008b), management approaches in Southern Africa started to shift towards conservation that included local communities in both the sharing of conservation benefits and in the management of the natural resources in the protected areas (Algotsson, 2006; Balint 2007; Fabricius et al., 2001). In terms of the "new" approach, people are recognised as the primary resource, or, as Summers (1999:193) puts it: “... it is essentially a bottom-up conservation approach", while Kothari et al. (1998:27) describe it as "conservation of biological biodiversity ... based on the involvement of local communities".

Despite this shift in biodiversity conservation, many of the programmes undertaken within this new management approach appear to have failed to provide communities with benefits that make a real and lasting difference to their livelihoods (Fabricius et al., 2001). In fact, the transfer of tangible benefits to local communities has been hampered by several factors, amongst others the lack of commitment among stakeholders (De Beer \& Marais, 2005), internal tensions and indecisiveness (Collins \& Snel, 2008; Guyot, 2005) and the conflicting interests of stakeholders (Decker et al., 2005; Sammy \& Opio, 2005). The new conservation approach, however, is also increasingly being challenged by a contrary perspective: in recent times there has been, as Brechin et al. (2007:39) articulate it, "... a renewed rhetoric advocating both (1) an abandonment of the social agenda related to conservation efforts ... and (2) a greater emphasis on, or return to strict preservationist practices". This basically represents an appeal from the ranks of "protectionist conservationists" for a return to the core mission of biodiversity conservation, and to do so without being burdened by efforts to accommodate social challenges and agendas. Despite this backlash rhetoric that has emerged in some circles, both the reigning conservation philosophy and conservation practice in most countries are still firmly embedded in a people-sensitive approach. This particularly applies to South Africa, where the People and Parks Programme of the new political dispensation is seen as an attempt to address some of the socio-economic ills that became associated with conservation during apartheid rule. For the foreseeable future thus, the once dominant narrative of fortress conservation has lost its official standing - both in Africa and elsewhere - in favour of a counter-narrative of people-centred conservation approaches.

\subsection{The nature of people-centred conservation approaches}

Many of the protected areas established before the 1980s had no or limited linkage to neighbouring communities. Conservation policy during that period dictated strict segregation between biodiversity protection (met by proclaiming protected areas) and poverty reduction (met by providing various forms of financial assistance). Once an area was earmarked for biodiversity protection, it was fenced off, and in many cases the local population within its perimeter was removed - sometimes even forcibly.

The 1980s, however, saw conservation agencies pioneering a variety of new approaches to protected area management - approaches that aimed to foster a stronger symbiotic relationship between conservation and development. Growing recognition that the social 
and economic needs of local communities had to be considered in conservation approaches had since spawned a number of innovative people-centred conservation approaches that allow for community involvement in biodiversity conservation and management. The common denominator in these approaches is the assumption that whenever communities feel that they are part of conservation efforts and where the conservation of the resources translates into benefits for the community, the sense of ownership and positive attitudes towards conservation can be enhanced (Simpson, 2009). Child (2004) confirms this in arguing that seeing protected areas as common resources which also generate value for the surrounding communities, conservation objectives can be achieved more sustainably. Poor rural communities - particularly those living adjacent to parks and other protected areas may potentially reap significant benefits from conservation spin-offs in protected areas. Such benefits span a wide range of opportunities, and could vary from employment opportunities, shared revenues, small-business development opportunities, and the sustainable utilisation of resources inside the protected area (Fabricius et al., 2001). It is nevertheless important to bear in mind that handouts alone will not necessarily contribute to either dynamic relationships or sustainable livelihoods. As Algotsson (2006) emphasises, communities should also feel that they are able to participate in the decision-making process and the management of the protected area.

Yet the new initiative towards people-centred conservation does not however imply a uniform or homogeneous approach, or even some kind of blueprint applicable to all communities and to all conditions. Labels such as community-based conservation, community wildlife management, integrated conservation and development projects, collaborative management models and communitybased natural resource management are commonly attached to initiatives of this kind. These approaches have become known under many different collective names, but the umbrella term "integrated conservation and development programme(s)" (ICDP), as suggested by Wells and McShane (2004), is perhaps the most descriptive and viable collective term for conservation initiatives with socio-economic development goals. Barrow and Murphree (2001) propose a threefold classification of ICDP approaches: protected area outreach, which is aimed at the education and economic benefit of neighbouring communities in order to enhance the biological integrity of protected areas; collaborative management, whereby conservation authorities and local communities (or their representative bodies) enter into agreements for access to natural resources under the jurisdiction of a joint management committee or other statutory monitoring authority; and community-based conservation that strives to put communities in control of the sustainable management of natural resources by placing the control over such resources in the hands of community structures. This broad typology of ICDP approaches, though useful as a theoretical construct, is nevertheless at best a simplification of the typologies of community conservation, and most conservation policies in Southern Africa tend to incorporate elements of more than one of the different types of ICDP approaches. The three proposed categories are thus not mutually exclusive when it comes to official conservation policies at the national level; yet they all subscribe to the philosophy of conservation with benefits to neighbouring communities.

Although many of the benefits offered by protected-areas management are non-financial in nature, these are nevertheless valued by communities (Fabricius, et al., 2001). Some of the non-financial benefits may include new and improved infrastructure, environmental education programmes, increased access to health, and to education training and information, improved relations between stakeholders, skills development that unlocks employment opportunities for local people, an increased sense of identity of communities 
and the building of local leadership (Fabricius et al., 2001; Simpson, 2009; Spenceley, 2008a). Direct benefits such as employment opportunities, for instance, may arise in terms of either the primary conservation function of the protected area, or through commercial tourism operations and accommodation facilities, or even a combination of these options. As described in Spenceley (2008a), shared incomes could take the form of tourism incomes through joint ventures with private operators, revenues from concession fees, communitybased tourism and accommodation facilities, and revenues from wildlife-utilisation activities, such as hunting fees and live game sales. Several examples of such initiatives, and in many cases a combination of them, can be found across Southern Africa and particularly in South Africa. In addition to the mentioned direct revenue streams that could be channelled to communities, indirect incomes could also be generated by developing local small and medium economic enterprises. This particularly applies to opportunities offered in the supporting and associated activities rendered to the protected area, such as the sale of goods and the rendering of services by both local entrepreneurs and the informal trade sector (Spenceley, 2006; Spenceley, 2008a).

These benefits - particularly the direct benefits - could, however, be limited and sometimes community members might feel that they are not deriving sufficient economic benefits from the protected area (Spenceley, 2005). In many instances, communities tend to over-estimate the potential financial benefits that can potentially be accrued. The reality, however, is that the latter are often negligible, particularly in the case of large communities, high poverty rates and many households that need to share the limited revenues on offer (Fabricius, et al., 2001). In other cases, the financial benefits could be limited to only those few members of the community directly involved in employment or tourism opportunities (Simpson, 2009:201). Yet despite such limitations, it should be emphasised that large segments of the said communities live in conditions of extreme poverty, high unemployment levels and with otherwise very limited options from which to derive an income. It therefore stands to reason that, when compared with other sources of income, the potential additional income that some households may expect to derive from opportunities in the protected area, no matter how marginal these may be, "can make a significant difference to people living on the edge of subsistence" (Fabricius et al., 2001).

The transfer of worthwhile benefits derived through biodiversity conservation is often hampered by one or more barriers - barriers that erode the benefits that accrue to local communities. Some of the most common barriers to the realisation of community benefits include inter-community rivalry and power struggles (Collins \& Snel, 2008; Guyot, 2005); a lack of commitment, and the conflicting interests of different stakeholders (Sammy \& Opio, 2005); weak or malfunctioning local structures (Fabricius et al., 2001); indecisiveness when it comes to decision making (Collins \& Snel, 2008); nepotism and undemocratic decision making (Guyot, 2005); the domination by elite hierarchies imposed by established tribal systems (Simpson, 2008); and, the non-equitable distribution of benefits (De Beer \& Marais, 2005). These barriers all contribute to constrain the progress of development projects; they dilute the potential impact of benefits and thus eventually also the success of povertyreduction initiatives in local communities.

\subsection{Protected areas as platforms for poverty mitigation}

Ever since the Stockholm Conference on the Human Environment in 1972, the links between environment and development and, more specifically, conservation and poverty, have been intensely discussed and fiercely debated - a debate that has gained momentum in recent 
times (Andam et al., 2010; De Sherbinin, 2008; Dudley et al., 2008; Simpson, 2008; Upton et al., 2008; Wells \& McShane, 2004). Scrutinising the social role of protected areas and their impact on rural livelihoods and development has become an increasingly central component of this debate (Naughton-Treves et al., 2005; Simpson, 2009; Spenceley, 2008b). In the Durban Accord of 2003, the World Parks Congress emphatically emphasised the role of protected areas as "... contributors to poverty reduction and economic development and as creators and sustainers of livelihoods" (World Parks Congress, 2003:2) and moreover continued to urge commitment to protected areas that strive to alleviate poverty amongst their neighbouring communities. Although much has been achieved in terms of understanding the links between conservation and development in different spatial contexts (Wells \& McShane, 2004), the absence of extensive comparative data on the dynamics of poverty among the communities surrounding protected areas worldwide continues to hamper comprehensive analyses of the interrelationships between protected areas and neighbouring communities (De Sherbinin, 2008).

The insistence on protected-areas management to contribute towards poverty reduction should be seen in the context of the prevailing poor economic development and the low levels of quality of life that typify rural conditions all over Africa. Almost two-thirds of the population of Africa are currently subsisting on less than US\$2 per day (PRB, 2009). Further complicating this situation is the fact that those African countries displaying the highest indices of poverty also enjoy the greatest coverage in terms of protected areas of The World Conservation Union's Protected-Area Categories I-V (Upton et al., 2008). Hulme and Murphree (2001) note that, in most African countries, rural communities surrounding protected areas are likely to experience poverty rates higher than the national average. Amidst these realities, the policy switch towards people-centred conservation in Africa has promised to alleviate poverty, not only by contributing to local economic growth, but also more directly by creating employment opportunities for the local people and, in some cases, providing increased access to resources within the protected area. It must however also be emphasised that the additional flows of income to households via community conservation initiatives in most cases is not of sufficient magnitude to make fundamental contributions to the eradication of poverty. Hulme and Murphree (2001) explain that although there might be a few cases where the economic benefits derived from a protected area could form an element of a poverty-reduction strategy, the magnitude, benefits and impact of these programmes are however too small to claim that they could become the cornerstone of a comprehensive poverty-alleviation programme, no matter how favourable the circumstances. At best, such programmes can hardly be more than a welcome supplement to the livelihoods of the poor, which means that such programmes should be seen as no more than additions to the more formal and existing human development programmes.

The size of a population (neighbouring community) living around a protected area is an important factor that determines the ability of any conservation outreach initiative to contribute to the well-being of the community (Dudley et al., 2008). In the case of a relatively small population that is reliant on the opportunities in a protected area, such opportunities and outreach initiatives could indeed make a significant contribution to poverty eradication. What this means is that the capacity of a protected area to function as a poverty-reduction tool strongly correlates with the size of the neighbouring community that stands to benefit from such opportunities: the smaller the target population - or the number of potential beneficiaries - the greater the outreach impact of the protected area is likely to be, and vice versa. In the face of significant population pressure, however, any attempt to promote a 
protected area as a vehicle for poverty alleviation will simply not be feasible (Dudley et al., 2008). Strategies that aim to reduce poverty, and that are initially successful may later run into problems if, for instance, they create such expectations as to encourage increased human migration to the protected area. If not managed with care, increased population pressure on the available opportunities may threaten to turn a potential "win-win" situation into a "lose-lose" one. Even successful examples of the mutually beneficiary relationship between biodiversity conservation and poverty reduction have their limitations and cannot necessarily be duplicated as blueprint models. Dudley et al. (2008) continue by emphasising that, in many cases, the most important socio-economic role of protected areas is fulfilled through benefits that are not narrowly interpreted in financial terms. If poverty is indeed understood and recognised as a multi-dimensional reality, then a protected area's contribution to poverty alleviation should not be confined to the financial aspects of poverty only, but should also allow for a broader social and economic scope. This perception of poverty reduction is clearly manifested in the South African approach of channelling conservation benefits to neighbouring communities.

\section{The South African approach to conservation}

Housing an estimated $10 \%$ of Earth's diversity of plants and animals, South Africa is considered the world's third richest country (following Indonesia and Brazil) in terms of biodiversity. Of all the vascular plant species found in South Africa, some $80 \%$ occur nowhere else on the planet (Pelser \& Redelinghuys, 2008). Notwithstanding this wealth in biodiversity, a series of factors such as population pressure, land degradation, overconsumption of resources, pollution and the expansion of agricultural land and urban settlements have interlocked to both cause and propel the destruction of natural habitats at an alarming rate. Strengthening the existing network of protected areas in the country therefore implies not only an improvement in terms of management effectiveness; it also requires that the protected area estate be expanded (Department of Environmental Affairs, 2009). To this end, a National Protected Areas Expansion Strategy (NPAES) was tabled in 2008 , its aim being to expand the current $6.2 \%$ of land area under conservation to $12 \%$ in order adequately to cover a representative sample of national biodiversity. The target of $12 \%$ will meet the $10 \%$ international target for terrestrial biodiversity cover (Department of Environmental Affairs, 2009).

Wishing to follow the example set by international practice, the official approach to conservation in South Africa had also traditionally been a protectionist ideology, i.e. one of excluding local people from management decisions and restricting the utilisation of biodiversity (Algotsson, 2006:82). Emerging in the late 1930s, this management style would form the basis of conservation policy in South Africa for some decades to come. Firmly embedded in the broader philosophy of apartheid that demonstrated disrespect for basic human rights, this conservation approach often resulted in forced removals of communities, social conflict, hostility towards conservation, increased levels of poverty and even further environmental degradation (Pelser \& Sempe, 2003).

With the dawn of the new political dispensation, SANParks (as the official conservation agency) gradually transformed from an institution of protectionist conservation to one embracing a community-oriented model that attempts to reconcile the conservation of biodiversity with the challenges of human needs and socio-economic development. Following the first democratic elections in 1994, SANParks initially inherited 17 national 
parks, including the second oldest and one of the most renowned parks in the world, the Kruger National Park. Today there are 22 officially proclaimed national parks in South Africa, and although the Kruger National Park is unrivalled in both size and biodiversity of plants and animals, the remaining 20 parks constitute important and representative examples of the country's many diverse ecological systems (see Figure 1).

SANParks' post-1994 approach to conservation hinges on linking conservation with economic development and human needs, i.e. on the inclusion of neighbouring communities rather than on the exclusion of the local population in its conservation practices. Unlike its predecessor, this conception of conservation is imbedded in a philosophy that embraces the principle of a harmonious relationship between parks and their neighbouring communities. It subscribes to the belief that the protection of biodiversity should be linked to human benefits and, if possible, the sustainable utilisation of resources. Essentially, this entails various initiatives aimed at improving the quality of life of neighbouring communities through options such as environmental education, recreational opportunities and the unlocking of economic opportunities. This change in conservation philosophy has been supported and enabled by changes in the legal and policy frameworks of environmental conservation in the country. The National Environmental Management: Protected Areas Act (Act No 57 of 2003 as amended in 2006), for instance, provides the legal framework for the People and Parks Programme of SANParks.

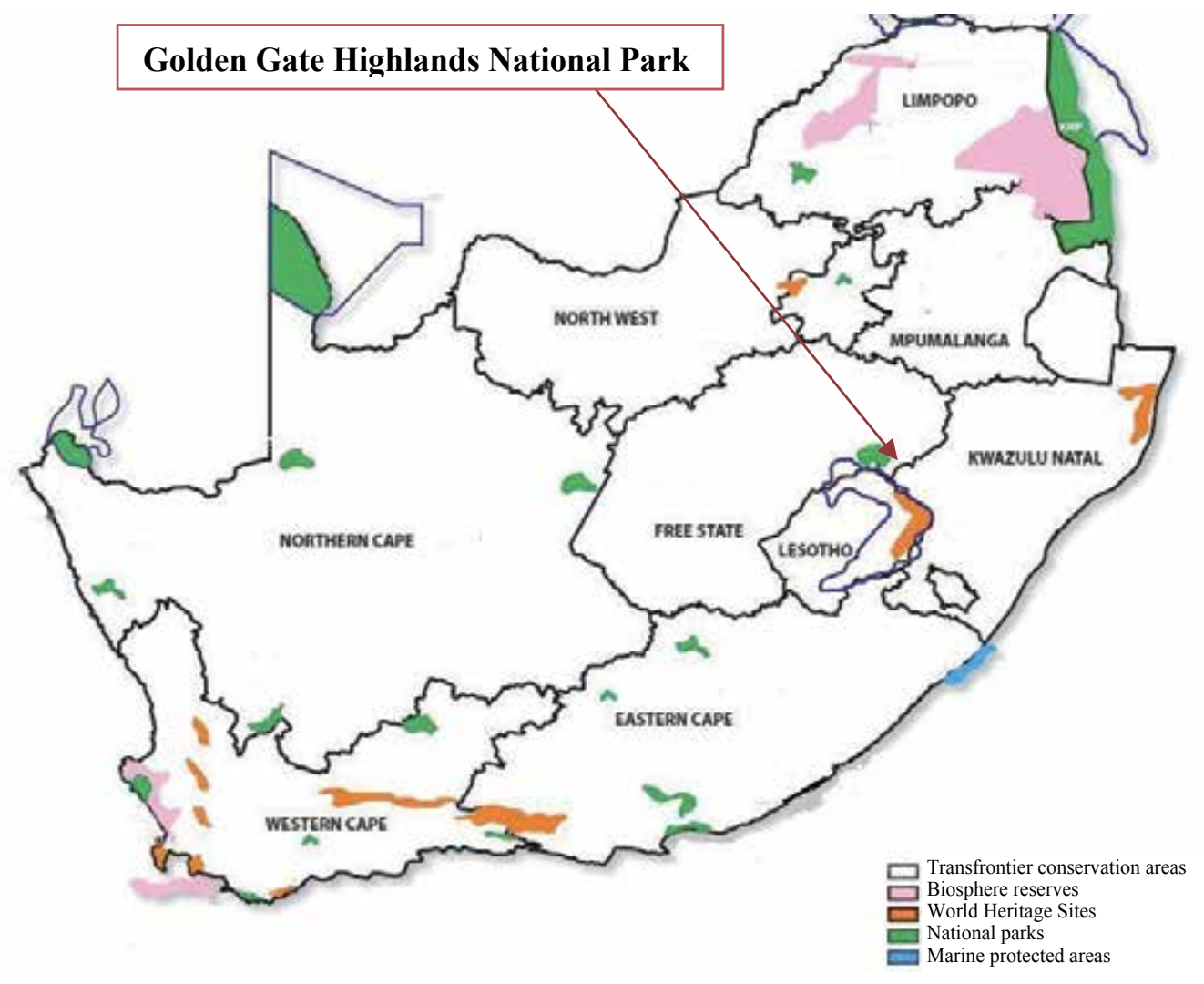

Fig. 1. Protected areas in South Africa (Department of Environmental Affairs, 2011, adjusted). 


\subsection{The People and Parks Programme of SANParks}

The People and Parks Programme of SANParks emanated from the World Parks Congress held in Durban in 2003. Several important themes emerged from this conference: The "benefits beyond boundaries" theme for instance emphasised the importance of providing socio-economic benefits to surrounding communities (Department of Environmental Affairs, 2009). The interdependence of communities and conservation was recognised, and the conference confirmed that protected areas can and should contribute towards the alleviation of poverty (Department of Environmental Affairs, 2009). The Congress further highlighted the important role of protected areas in sustainable development and of the conservation of biodiversity and the mitigation of poverty amongst neighbouring communities. The People and Parks Programme should be seen as a direct response to these concerns, and embodies the South African Government's efforts to address land reform, rural development and conservation in a coordinated and holistic fashion.

A strategy to develop new management plans for national parks in South Africa through a range of stakeholder engagement processes has seen 18 parks with representative forums facilitating public participation in park management (Department of Environmental Affairs, 2009). Several outreach initiatives serve as examples of how the new approach embraces the philosophy of integrated conservation and development: since 2007, more than 300,000 school children have enjoyed free access to national parks; cultural heritage repatriation and sites - including historical graves - are promoted and managed in most national parks; an average of 5,100 people per annum are employed in a conservation-related extended public works programme (EPWP); and sustainable resource-use projects are run, which allow and assist communities in harvesting resources from national parks in sustainable and economically beneficial ways (Department of Environmental Affairs, 2009).

The main objectives of these environmentally oriented programmes are enhanced biodiversity through the clearing of alien plant species and rehabilitation of infiltrated wetlands and other areas, the construction of conservation-related infrastructure (roads, rest camps, fences, etc.) and the facilitation of the development of small and medium enterprises within the neighbouring communities. Depending on circumstances, a total of 2,000-8,000 people are employed annually by the EPWP nationwide (Department of Environmental Affairs, 2009). The EPWP is a government initiative to mitigate poverty by encouraging labour-intensive activities and by providing temporary employment opportunities, particularly by targeting deprived communities and vulnerable sectors within these communities. There are four programmes specifically dedicated to job-creation opportunities in the environmental sector, i.e. People and Parks (focusing on infrastructure), Working for Wetlands (wetland rehabilitation), Working for Water (alien vegetation removal) and Working on Fire (fire control and prevention). As indicated in the next section, these programmes exemplify Golden Gate Highlands National Park's efforts to contribute to the alleviation of poverty in communities adjacent to the park.

\section{Case study: Poverty alleviation in the Golden Gate Highlands National Park}

\subsection{About the park}

The Golden Gate Highlands National Park (Golden Gate) - one of 22 national parks in South Africa and the only in the Free State Province - is nestled in the foothills of the Maloti Mountains in the north-eastern part of the province (see Figure 1). The park comprises more than 30000 hectares of highland habitat and is home to a large variety of mammals, 
including 10 antelope species and almost 900 bird species. Specially protected fauna in the park include the endangered Cape Vulture, the Bald Ibis, the rare Bearded Vulture, the endangered Oribi and the Sungazer. Golden Gate is currently the only national park in South Africa that protects the Afromontane Grassland biome, the most neglected biome from a conservation point of view. More than 60 species of grasses have been recorded in the park (SANParks, 2011). Grassland can support vast herds both of domestic and wild animals and also serve as protection for crucial wetlands. South African grasslands constitute the second largest ecosystem in the country and are collectively protected not only by three World Heritage Sites but also by many provincial reserves and national parks. Golden Gate offers one of the best places to appreciate grassland conservation in South Africa. The park is also part of an ambitious international conservation project that extends from the Eastern Cape, all along the Drakensberg mountain range through KwaZulu-Natal and into the Free State on the South African side of the international border with Lesotho to constitute the Maloti-Drakensberg Transfrontier Project.

Golden Gate is situated in one of the most important water-catchment areas in South Africa and more than $50 \%$ of the country's water supply comes from this area (SANParks, 2011). The initial park of 4, 792 ha was proclaimed on 13 September 1963 at a time when parks were mainly established for pristine-area protection. The park was subsequently enlarged in 1981, 1983, 1988-89 and again in 2008 - to reach its present size of 34000 ha (SANParks, 2011; Taljaard, 2010). Apart from its aesthetic beauty and the fact that it represents the threatened grassland biome, the park also has major geological significance. The geological formations in Golden Gate were created by swampy rivers and volcanic activity over a period of 160-200 million years ago to form three main layers of rock: a red layer, yellow sandstone deposits and basalt (SANParks, 2011). These rock layers also inspired the name of the park: Golden Gate derives its name from the soft shades cast by the setting sun on the west-facing sandstone cliffs, which turn the cliffs into a glowing gold colour. Archaeological findings at Golden Gate (particularly stone tools and rock paintings) suggest that the Stone Age Khoisan people (Bushmen group) were the first inhabitants of the area, using the many overhangs and caves in the park as shelters. Equally important paleontological discoveries were made in 1973, when the first ever fossilised dinosaur eggs with foetal skeletons of the upper Triassic Age (200-230 million years) were discovered in the park. The initial identification of the dinosaur eggs was for many years disregarded by the scientific community, and only in 2008 was it proved that the fossils did indeed contain the remains of Massospondylus embryos - a find that catapulted the larger Golden Gate area as one of the most important dinosaur fossil sites in the world (Tucker, 2010). The 1973-discovery was since followed by the discovery of several examples of fossilised dinosaur bones and footprints.

Conservation management in the park faces three main challenges: erosion control, alien plant control and fire management. Problem plants in the park include Poplars spp., Blue Gum spp., Wattle spp., Prickle pear, Weeping Willow, Pine spp., Bramble spp. and Black Berry. The Golden Gate soil is very sensitive to erosion by wind, water, stock path and fires from neighbouring communities. The wetlands in the park are particularly diverse and highly important for biodiversity conservation, but are degraded as a result of the overgrazing practices of earlier farmers before the park was proclaimed. Wetland rehabilitation initiatives in the park therefore attempt to stabilise soil erosion and silt that are washed into the wetland. At least six distinct vegetation types are common to the wetland area, and rehabilitation intervention is mainly in the form of gabion structures and 
earthworks (Working for Wetlands, 2010). The rehabilitation and conservation of these wetlands - in which members of the neighbouring communities play an active role - are of paramount importance for water catchment and water security in South Africa.

\subsection{The neighbouring communities of the park}

Although the concept of "neighbouring communities" is central to SANParks' peoplecentred conservation approach, the definition and demarcation of such communities often create numerous challenges. For the purposes of this discussion, the concept "neighbouring communities" denotes groups living in close proximity to Golden Gate, or groups that may live some distance from the park, but nevertheless may have reasonable expectations in respect of benefitting from opportunities created by the park (SANParks, 2000). Within the South African historical context, and given the broad objectives of the People and Parks Programme, the concept usually refers to black and "coloured" communities residing in rural or semi-urban settlements. Yet, as in the rest of Africa, several challenges confront rural areas in South Africa and thus also the communities in these areas. These challenges include poor access to both socio-economic infrastructure and services, low levels of literacy and skills development, socially disruptive migratory labour practices, as yet unresolved restitution and land-tenure issues, the overconsumption and/or unsustainable use of natural resources, and high rates of unemployment and poverty with a consequently high dependency on social grants and other forms of social security. The rural population surrounding Golden Gate is no exception to this trend.

Golden Gate and the surrounding areas fall within the boundaries of the Thabo Mofutsanyana District Municipality (TMDM) - one of five district municipalities in the Free State Province. With a total population of 694319 (2007) - 93.7\% of whom are black people TMDM is the district with the second largest population in the Free State (South African Institute of Race Relations, 2010). The average household size is 3.7, which is more or less equal to the national average. Because of the dynamic of migrant labour in the district, the gender distribution is somewhat skewed, with almost $54 \%$ of the population being females by far the highest female proportion of any district in the province. One in every three persons (32.2\%) is 14 years or younger, and a staggering $64.2 \%$ of the population (or 445753 persons) were living in poverty in 2007 (South African Institute of Race Relations, 2009). In fact, not only does TMDM have the highest poverty rate of the five districts in the Free State, it also registers one of the highest poverty rates for district municipalities in all of South Africa. The district is thus characterised by relatively low levels of socio-economic development, low literacy and/or education levels and a high unemployment rate. To add to this, the 2009 South African Antenatal Survey reported an HIV prevalence rate of 31.3\% among pregnant women in the TMDM (National Department of Health, 2010). In general, the majority of the people in the area - particularly those on the north-eastern boundaries of the park - are hamstrung by low levels of human development and a low quality of life.

\subsection{The Working for Water and Working for Wetlands Poverty Alleviation Programme at the park}

As mentioned earlier, alien plant control and wetland rehabilitation are major challenges to conservation management in Golden Gate. Invasive alien plant species cover an estimated $10 \%$ of South Africa and are increasing exponentially, to such an extent that they are considered the single biggest threat to South Africa's biological biodiversity (Department of Water Affairs, 2011). These plant species pose a direct threat to water security, land 
productivity and to the optimal functioning of ecological systems in the country. The Working for Water Programme in the Department of Water Affairs was nationally launched in 1995 and is leading the fight against invasive plant species. The programme enjoys international recognition, not only as an admirable example of environmental conservation in Africa, but also for its role in job creation and poverty reduction (Department of Water Affairs, 2011). The socio-economic empowerment and development of the local population is recognised to be an integral part of environmental conservation, hence initiatives such as skills training and HIV/AIDS projects are also important objectives of Working for Water.

The Working for Water and Working for Wetlands Poverty Relief Programme at Golden Gate was launched in 2002. Both Working for Water and Working for Wetlands are informed by the EPWP in terms of policies, the recruitment of workers and the duration of their contract. SANParks' Department of People and Conservation at Golden Gate assists in identifying target groups through an advisory committee. Workers are recruited both from neighbouring communities - Monontsha Village, Mabolela, Bluegum Bosch, Clarens, and Eerstegeluk - and from neighbouring farms. Members of these communities serve on the advisory committee and help to identify previously disadvantaged people. The programme aims to target $60 \%$ women, $25 \%$ youth, and $2 \%$ disabled people in the recruitment process and in the identification of beneficiaries (Nthangeni, 2011).

Close on 770 people have been employed since the inception of the programme in 2002, and a total amount of R3.1 million (US $\$ 500,000)$ was spent locally on wages, materials and training during the period 2007-2010. Local people employed in the project are empowered by means of training courses while they are working on the programme. In addition to project- and task-related training such as gabion-building and skills development of workers, this also includes courses in health and safety, personal finance, business management, fire awareness, first aid and general environmental awareness. This training, while enabling workers to accomplish the tasks associated with wetland rehabilitation and clearing of alien plants, can also be used as foundation for further economic empowerment and capacity building when the beneficiaries exit the project (Nthangeni, 2011). The Golden Gate initiative thus clearly demonstrates the characteristics of a protected-area outreach programme, in accordance with the typologies suggested by Barrow and Murphree (2001) as discussed earlier.

Benefits of this initiative fall into three categories: direct benefits to the community, indirect benefits to the community, and benefits to the park. Benefits to the park mainly encompass the provisioning of labour power to rehabilitate wetlands and free it from invasion by alien species, thereby contributing to the recovery of indigenous fauna and flora and, ultimately, to achieve the conservation objective of the park. Direct benefits to the neighbouring communities include financial benefits for those involved in the project, capacity building and benefits achieved through increased social awareness. The programme also arranges special social days or events as further direct benefits to the community. This initiative aims to promote environmental awareness (such as, for instance, celebrating World Wetland Day) and social education (specifically HIV/AIDS awareness and knowledge). Women's Day and World Aids Day are further examples of social awareness initiatives annually celebrated by the programme. Local schools also visit the park for a week-long programme that includes field visits to wetlandrehabilitation areas with a view to experiencing mechanisms used to stabilise soil erosion and soil decomposition caused by moles. Indirect benefits, on the other hand, relate to households and extended families who depend on the wages of those employed in the 
programme; the provision of clean water to households affected by both the rehabilitation of wetlands and by clearing them of alien plants; and, to goods and materials that are purchased from the local market and used in the running of the programme. However, as mentioned earlier, the sustainable impact of these benefits has not once been assessed since the inception of the programme at Golden Gate.

\section{Research design and methodology}

The field study made use of a qualitative methodology and was designed around a hybrid of primary and secondary data to constitute a sequential mixed-method approach. Following an evaluative design, existing secondary sources of information that focused both on the people and parks interface and on institutional arrangements and barriers to community benefits were reviewed and interpreted, and eventually also supplemented by primary data collected by means of focus-group sessions and semi-structured interviews with beneficiaries of the programme.

The field study was designed in accordance with the principles of programme evaluation. Programme evaluations are conducted for several reasons, amongst others to (i) improve the efficiency of a service, (ii) to plan more effectively and (iii) to improve existing programmes (Alston \& Bowles, 2003). Using outcomes analysis as a framework platform for programme evaluation, this study determined the extent to which the objectives of a poverty-relief programme at Golden Gate have to date been met and how the programme can be strengthened by identifying and addressing the impediments to the implementation of the programme. Key questions underpinning the outcomes analysis included: How successful is the programme? What barriers have prevented the optimal outcomes of the programme? How satisfied with the programme are the beneficiaries? Does the programme reach its target community effectively? How can the programme be improved? (Alston \& Bowles, 2003).

In order to assess the impact of a poverty-relief programme at Golden Gate, it was important to have clear definitions of what was understood by concepts such as "poverty", "poverty reduction" and "well-being". There is no universally acceptable definition of "poverty", except perhaps for the widely applied US\$1 or US\$2/day criteria used by the World Bank and United Nations agencies. This measurement of poverty, however, poses different challenges in different contexts. While in narrow terms related to income, the essence of poverty can possibly best be summarised as being a lack of opportunity or an inability to achieve one's potential (Dudley et al., 2008). The World Health Organisation (1997:69) therefore argues that poverty exists "... when individuals or groups are not able to satisfy their basic needs adequately", with "basic needs" comprising food, social and cultural life, primary education, health, and favourable living and environmental conditions (clothing, shelter, water, air, etc.). Closely related to/associated with poverty and poverty reduction is the concept of well-being. The United Nations Environment Programme (2004:2) states that "[T]here is widespread agreement that well-being and poverty are the two extremes of a multi-dimensional continuum". This implies that if we understand poverty as a multi-dimensional state of human development rather than just a question of income, then protected areas have more chances of contributing to poverty reduction (Dudley et al., 2008). This, in fact, was also the operational definition and approach to the measurement of poverty reduction adopted for the programme evaluation at Golden Gate. 
Stemming from the above and following the methodology of the World Wide Fund for Nature (Dudley et al., 2008), five fundamental dimensions of well-being were recognised for the purposes of the field study. Thus, any improvement in the following dimensions as confirmed by the outcomes analysis of the programme evaluation should contribute to poverty reduction:

1. The subsistence dimension: These are non-economic programme benefits that contribute to human well-being, i.e. health, nutrition, clean water and shelter.

2. The economic dimension: This dimension refers to programme benefits that provide participants with the ability to earn an income, to consume resources and to possess assets.

3. The cultural and spiritual dimension: This refers to programme-related activities that instil a pride in community, confidence, and which promote living culture, spiritual freedom, and further education.

4. The environmental services dimension relates to the role of the programme in promoting environmental stability and providing natural resources.

5. The political dimension allows for programme activities or objectives relating to issues of governance and thus influences decision making.

\section{Findings}

The ability of this specific programme to contribute to the alleviation of poverty and to increasing the levels of human well-being in the target communities identified above were assessed by drawing on the views and opinions of beneficiaries in relation to the above five dimensions. The first dimension to be addressed is that of subsistence.

\subsection{Subsistence dimension}

Focus-group participants indicated that the programme had significantly improved their lives and that there had been an improvement in their overall standard of living as a result of the programme. Beneficiaries recurrently used the phrase "improved a lot" to express the improvement in their overall standard of living after they had started working on the programme and expressed the view that they were "being taken out of poverty" by working on the programme. All the focus-group participants unanimously agreed that the programme had improved their lives and those of their families in many ways. When asked to comment on whether they had experienced an improvement in their general well-being and quality of life, respondents' reactions included statements such as "Oh so very much" and "Oh yes, my life improved so much". The reasons given for this perceived improved quality of life relate, amongst others, to better health and an increased ability to provide for basic needs such as of food, shelter and clothing.

Beneficiaries insisted that, through working on the programme, their health had improved markedly. Before starting to work on the programme, some of them constantly fell ill, but this was seemingly no longer the case since having joined the programme. Resulting from the combined impacts of regular exercise and sufficient water intake, participants perceived themselves to be much healthier than before they had started working on the programme. Some participants experienced healthy weight loss directly linked to the physically demanding nature of the work on the programme, which includes walking long distances in the mountainous terrain of the park. The health benefits derived from working on the programme are undoubtedly more multi-dimensional and 
comprehensive than those mentioned above. Better health also resulted from the improvement in the economic means of participants, as earning an income had since enabled them regularly to purchase sufficient and better quality food. Beneficiaries were also able to improve their housing conditions and the type of fuel used for domestic purposes such as cooking and heating. Therefore, they were better able to insulate themselves and their families from the effects of diseases associated with poverty and poor living environments. A further dimension of health highlighted by participants was the increased psychological and mental well-being that they experienced as a result of their involvement in the programme. One participant articulated the psychological health benefits experienced as follows: "I was constantly diagnosed with stress [before I started working on the programme] because I could not provide for my children, but now I no longer have stress. I am able to provide for my family."

In addition, beneficiaries were able to afford better health care and this further raised their health status and quality of life. A participant whose mother suffers from diabetes explained that, in the past, the family could neither afford to take her (the mother) to a doctor, because of being unable to afford the consultation fee, nor were they able to buy the medication that a private doctor would subscribe for her diabetes. Consequently, they were obligated to use the services of the under-resourced local primary health care clinic and her condition did not improve. Since being on the programme, this particular beneficiary was subsequently able to take her mother to a private doctor and to purchase the necessary medication for her. Thus, beneficiaries on the programme were able not only to improve their own quality of life, but also those of their extended families. The improvement in the quality of life of beneficiaries also had an economic dimension to which attention now turns.

\subsection{Economic dimension}

As explained earlier, this dimension refers to programme benefits that offer participants opportunities to earn an income, to consume resources and to possess assets. Local people employed on the programme obtain their wages directly from the project and therefore benefit financially from the programme. Beneficiaries thought it important to have the park here "because if it was not here we would not have been employed on this programme". The participants in the focus groups all associated the programme's success with its ability to create employment for the poor - an impact participants considered to be the most important benefit of the programme. Beneficiaries also expressed their pride in and gratitude towards the park because of the effort made by the park to alleviate poverty. One beneficiary stated: "[I am] grateful to this park because I managed to find a job within the park", while another maintained that she "like[s] the park a lot because we are now working on the ... programme". Yet another beneficiary was "very proud of this park because it took us out of poverty by giving us an opportunity to work here".

Beneficiaries were generally satisfied with the financial benefits attached to being involved in the programme. They pointed out that they were compensated well for their work and that the income they received had contributed significantly to improving the quality of life and the well-being of their families. As a result of the income received, they were now in a better position to provide for their families' basic needs and their families could now afford to live a better life. The phrase "able to provide", voiced by several beneficiaries, underscores the link between the increased economic means of the beneficiaries and their current ability to fulfil their basic subsistence needs. In this regard one beneficiary remarked: "The best thing 
for me is being able to work and earn some money, because without money you will not be able to live and survive." In an isolated case, a single mother indicated that because of her particular family's needs, the income earned was not enough. Nevertheless, she still agreed, "... it is true that this money does help", at least, to meet some of her family's immediate needs - even if she had no money left for less urgent needs.

Beneficiaries however expressed their discontent over the current payment procedure, which, according to them, was not conducive to their economic well-being. While being generally satisfied with the remuneration that they received through the programme, beneficiaries had an issue with the frequency with which money was paid out to them. The beneficiaries emphasised that they did not always get their salaries on time, or that they would be paid less than anticipated, which made it difficult for them to budget. Sometimes they would thus not be able to fulfil their basic needs. They described the payment procedure as being a lengthy and drawn-out one and felt that "sometimes ... weeks [or] even a month would pass without getting paid". Thus, while beneficiaries did generally feel that they received adequate remuneration for their work, they were sometimes confronted with an inability to provide for their families owing to the payment procedures currently followed. This directly affected their ability to provide for the needs of their families, contributed to additional stress over their financial situation and, consequently, affected their quality of life.

The programme enabled beneficiaries to buy household items and commodities that they had in the past been unable to buy. Among the most important needs highlighted by beneficiaries were food, children's clothing (notably school uniforms) and furniture. Some beneficiaries were also able to open store accounts because of the steady income they received from the programme. They were therefore able to purchase more expensive household items, such as furniture, on credit. Some beneficiaries were also able to settle old debts (mostly store credit accounts) with the money earned from the programme, which markedly improved the financial position of these families. Money earned while working on the programme enabled them to build houses for their families, while others were able to expand their current dwellings with the income earned by working on the programme. One beneficiary pointed out that she "was able to buy building material and now my children are no longer sleeping in a shack. I have built a house with two rooms".

Beneficiaries were intensely aware of their advantageous economic position in relation to that of the rest of the community. One beneficiary felt that "... we could see the difference between us and people who were still unemployed". The prevailing magnitude of poverty amongst neighbouring communities, however, makes it difficult effectively and comprehensively to impact on poverty reduction by means of one single poverty-relief initiative. Participants pointed out that there were simply not enough employment opportunities available in the communities from which they came. Therefore, even though not wanting to rely solely on programmes such as this one to provide employment, they felt that there were simply not that many other employment opportunities available in the community. Participants pointed out that it was "very difficult for us to find jobs in this area", or asked "[N]ow tell me how it is possible to find employment in this area?!" It was also pointed out that "there are so many people who want this job", which is a clear indication of the extent of the poverty and levels of destitution in these communities.

In the face of the overwhelming needs of the communities targeted in this programme, one should not expect a programme such as this to to be the single answer to alleviating the suffering of people in these communities. On the other hand, it would be imprudent to deny 
the definite impact that such a programme has on improving the well-being of at least a small number of families through providing them with the economic means necessary to improve their quality of life.

\subsection{Cultural and spiritual dimension}

The cultural and spiritual dimension of a programme evaluation addresses the ways in which the programme instils a sense of pride in community, improves the psychological well-being of community members, promotes the living culture of the community, and furthers education in these communities.

\subsubsection{Sense of community}

Beneficiaries displayed a strong sense of community solidarity, expressing the wish that the programme would do more to alleviate poverty in their communities. Some beneficiaries wanted others in their community also to experience the benefits of employment and higher quality of life that they were experiencing through the programme. To achieve this, some beneficiaries indicated that they attempted to share what they had learned on the programme with other people in the community, either formally through community awareness campaigns or informally in their day-to-day interactions with other community members. As a result of such initiatives, many of the beneficiaries mentioned an increased awareness of specific social issues like HIV/AIDS and also emphasised the importance of putting into practice what is learned through participating in social and environmental awareness programmes of this nature.

\subsubsection{Confidence, self-worth and a sense of independence}

Poverty has a demoralising effect on individuals and families and, as a result, people trapped in poverty may display a sense of fatalism and may also lack a sense of selfworth. The desperation felt by breadwinners who are unable to fulfil their family's financial needs in the face of poverty and unemployment was highlighted by a number of the beneficiaries. A male beneficiary pointed out that it is "bad for a man [of the house] not to work and seeing your family suffering while you are suppose[d] to provide for them", while another beneficiary emphasised that "there is nothing that is more demoralising than a woman providing for her husband". By working on the programme these participants were able to achieve a sense of accomplishment in providing for their families, particularly within the context of a rural patriarchal culture in which economic provision is still regarded as a predominantly male function within the family. One male beneficiary remarked in this regard that "working on this programme has made me feel proud of myself as a man and that made me feel good".

Both male and female beneficiaries felt that the programme had contributed to their sense of accomplishment, self-worth and self-confidence. A female beneficiary remarked that she looked at herself differently since being on the programme, while another beneficiary stated that she felt "like other women" because her house was now in a better state than it had been before because of the money she had invested in her house and in household items. According to some participants, one of the best aspects of the programme related to being able to wake up every morning and go to work "because as a person you become fulfilled by that". Ultimately, the programme contributed to restoring people's sense of dignity and, as one beneficiary observed, to making them "feel like humans again". 
Another aspect that contributed to the higher sense of self-worth and confidence experienced by the beneficiaries was the increased financial independence that flowed from working on the programme. Resulting from the increased financial independence of these poor households, they relied less and less on their extended families - notably elderly parents - for financial assistance. Beneficiaries claimed that they were now able to provide for themselves and that they no longer relied on their parents for financial support; others, again, expressed their sense of financial independence in much stronger terms, such as "I do not feel like my parents' burden anymore". The fact that beneficiaries were earning an income held additional benefits for the extended families since beneficiaries were, in turn, able to assist their aged parents with money. Especially among women working on the programme there was an emphasis on the ability to care for their children without having to wait for their husbands to provide them with money for food and clothes.

This independence was, to an extent, undermined by the insecurity beneficiaries experienced over when exactly they were paid for their work. Beneficiaries referred to the cumbersome payment system that led to financial insecurity and an inability to plan around the money that they would receive. However, as one beneficiary pointed out; "I think [the programme has] helped us a lot. Even though we only received our salaries after a long time, the fact is our salaries remained our salaries and we were able to do whatever we wanted with our salaries."

\subsubsection{Improved future prospects}

The programme also markedly influenced how beneficiaries felt about their future prospects in terms of employment and sustained quality of life. Beneficiaries believed that, because of their involvement in the programme, they were now able to plan for the future. Some beneficiaries felt that they would be in a position to start their own businesses once they exited from this programme because of, on the one hand, the training that they had received, and, on the other, , because of having been able to save money to start up new businesses. There were, in fact, beneficiaries who were already involved in entrepreneurial pursuits in addition to working on the programme. One beneficiary stated that his life had improved since he was - in addition to working on the programme - now also a small businessman. This particular participant used some of his income from the project to settle his college debt and to buy shares both in a small liquor store and in a cellphone company. Thus, the programme, in addition to providing immediate relief from poverty and a marked improvement in the quality of life of participants, also enabled participants to branch out into other ventures that would steadily improve their future prospects. These successes were nevertheless limited and occurred on a small scale.

\subsubsection{The promotion of living culture}

Although not an objective of the programme as such, it appears that the programme contributed to the promotion of living culture in the target communities. Most notable in this regard was the impact that the programme had on the empowerment of women in the target communities. This was a significant contribution of the programme, since there were a large number of female-headed households in these communities experiencing extreme levels of poverty. One beneficiary observed: "I think this programme helps women around this area more because most of the households around this area are women-headed." Thus, the 
programme, through improving the economic position of women in the communities, enabled them the better to support their families, which contributed not only to raising their confidence and sense of self-worth, but also contributing to the upkeep of other members of their families.

It transpired that the programme also served to sensitise male beneficiaries to the issues of gender and gender equality. One male participant expressed it as follows: "Sometimes men tend to abuse their authority and powers within their families and through this training I was taught, as a man, that I should consider and treat my wife as an equal and that has helped me a lot in my family. I practise that in my family and now I have a happy family." The programme thus had an indirect impact on improving the functioning of families in the target communities.

\subsubsection{Further education}

Capacity building was one of the direct benefits of the programme. Local people involved in the project were empowered through training received while working on the programme. The skills obtained through the training were seen as a form of capacity building that was able to benefit beneficiaries even after they had exited the programme. The type of training mentioned by focus-group participants included training in respect of personal finance management, business management, first aid, health and safety training, contractor development, firefighting, and herbicide and pesticide application.

Beneficiaries confirmed that they had learned a wide range of skills on the programme and were pleased that they received certificates for all training sessions attended, believing that at a later stage they would be able to use these certificates to apply for other employment opportunities, for example in hospitals. Some of the participants mentioned having received computer training and they believed that this too would improve their chances of securing future employment. Beneficiaries were positive that since they were able to add work experience to their curricula vitae and attach certificates to job applications when applying for vacancies, they would be able to secure employment even after having left the programme.

Others emphasised the generic skills learned through the programme. These included leadership skills and the ability to work with people from different backgrounds. One beneficiary also indicated that she had progressed through the ranks of the programme from a worker to a supervisor - and now works on the programme as a contractor, therefore being able "... to grow as a leader within the programme". Several of the beneficiaries expressed a desire to start their own businesses at some time in the future. Some beneficiaries strongly believed that the training they had received would help in these endeavours.

In addition to the training received, the programme also enables participants to further their education. Many of the beneficiaries mentioned that they had been able to save money, either to settle outstanding college debts, or to further their education. In one instance, a beneficiary was able to pay her outstanding college fees and, as a result, could receive her college certificate. Since having received her college certificate, her future employment prospects expanded and improved considerably. Beneficiaries also indicated that the income received enabled them to pay for their children's, and in some cases, their family members' further education. One beneficiary recounted: "Before I started working on this programme, my parents died and my sister had to drop out of college. However, after being employed on this 
programme, I made arrangements with the college to pay for my sister's studies and now she has completed her studies." The programme therefore considerably raises the future prospects of beneficiaries and their dependants in terms of future employment, thereby making a significant contribution to improving the socio-economic well-being of the people in these target communities.

There is also recognition by the beneficiaries that the programme offers particularly valuable opportunities to those who are uneducated. This was important in the eyes of the beneficiaries in this study since they pointed out that employers are generally more interested in appointing people who have at least some education. The programme thus provided them with an opportunity both to receive basic education and training and consequently to improve their prospects for future employment.

\subsection{Environmental services dimension}

The environmental services dimension touches on the role of the programme in environmental stability and the provision of natural resources. Beneficiaries were asked to comment on their awareness and understanding of the role of the programme in promoting environmental sustainability. They were also asked to indicate their awareness regarding the programme's role in the provision of resources, such as water, to their own communities and to other parts of South Africa, these being included in the environmental objectives of the Working for Water/Working for Wetlands Programme.

Beneficiaries are, to a certain extent, aware of the larger environmental benefits of conserving this particular park. They are also, to an extent, aware of their contribution towards this endeavour, but do not generally link the conservation of the park with larger issues such as water provision for their communities and other areas. Only a few of the participants were able to link the conservation of the land and wetlands in the park with bigger issues such as national water security. One beneficiary observed: "We were told that this park supplies other South African provinces with water and electricity". Another beneficiary stated that "I did not know that some of the trees in my yard consume lots of water. I did not even know that we have a shortage of water in our country, but I now know all about this and I am grateful for what I have learned". Yet another beneficiary emphasised: "The programme has opened my eyes, because I never knew about wetlands." However, some stated outright that they did not know the reasons why the park had to be conserved and that no one had explained it to them before.

Focus-group participants felt proud to be a part of the conservation efforts in the park. Several participants made mention of the abundance of animal species in the park that needed to be conserved and felt that the park was conserving the natural environment well. They were generally proud of the park because it gave people the opportunity to visit the park and to see the "beauty of nature such as animals and mountains within the park". Beneficiaries were grateful that their children were given the opportunity to visit the park and be educated about the environment and conservation.

Focus-group participants further specifically pointed out that before they had worked on the programme, they had been unaware of the threats posed to water and soil by alien trees. Beneficiaries generally commented that they neither knew how to distinguish between different types of trees nor how they impacted on the environment, but that the programme had changed this. They pointed out that they were now aware that some trees were a threat to the environment since they consume large volumes of water and contribute to soil 
erosion. Some participants indicated that they had been surprised to learn that some of the alien trees had strong root systems able to damage their houses. Another beneficiary observed that her grandmother "had an alien tree and her other trees could not grow well, because this tree was consuming a lot of water. I advised her to remove the tree from her yard. After she has removed the tree, her peach tree is growing very well".

As a result of the programme, beneficiaries were thus able to develop a better understanding of the dynamic relationship between environmental issues and their own quality of life. They were able to apply this knowledge and awareness to improve their own well-being and quality of life. However, as one participant pointed out, in spite of this knowledge they did not have the same equipment or chemicals available in their communities as those that they used on the programme to act on this knowledge; some however indicated that they would like to "do the same things we are doing in the programme in [our] communities". Some participants indicated that they were sharing this knowledge, particularly about alien plants, with other members of the community.

\subsection{Political dimension}

The political dimension relates to how the programme objectives link up with issues of governance and decision making in target communities. Resulting from the process by which beneficiaries are selected for the programme, it transpired that community members to an extent felt that they would have liked to have more influence when it came to the selection of beneficiaries. General workers are identified by the politically elected ward councillors in each community. The assumption is that the ward councillors are best able to identify those in their particular wards who are most vulnerable because of being poor and therefore they (the councillors) are best placed to select potential beneficiaries. Beneficiaries affirmed that the councillors were aware of the socio-economic status of each household in their ward, thus knowing exactly who was struggling and who could not provide for their families. This qualified them to make the decision as to whom to select to work on the programme. One beneficiary conceded that the councillors were perhaps sometimes not fully aware of the socio-economic status of the people in their wards and further used outdated data on the strength of which to select people.

Some of the beneficiaries, however, were not entirely satisfied with the way in which the programme relied on political councillors to be involved in the selection of workers. It appears that councillors would sometimes show favouritism and only select people who were loyal to them politically. As a result, people who did not really qualify for the programme were sometimes selected, or in some cases, more than one person from the same household was selected. Beneficiaries particularly pointed out that often the councillors would select people who were less needy, while there were other families experiencing more severe conditions of poverty and who would therefore benefit more from working on the programme. However, from discussions with the management of the park it transpired that the ward councillors do not independently decide who will be most likely to benefit from the programme: after identification of potential beneficiaries by ward councillors, identified beneficiaries are selected with the inputs of a larger advisory committee that include the councillors, members of the community, and also park employees. Yet, the focus-groups sessions revealed that the selection process could benefit from better communication between the community, the councillors and the programme management. 
Some of the respondents expressed the need for similar programmes in their target communities. One respondent remarked: "I think it is a good programme because it has helped people to improve their standard of living and I wish there were more programmes of this nature throughout poor communities." In addition, participants criticised the programme for not creating enough opportunities for either employment or further economic development. Given the above, the following conclusions are drawn with regard to the programme.

\section{Conclusions and recommendations}

The future of biodiversity conservation and the socio-economic needs of local people are strongly intertwined. Collaboration with local communities will remain essential if protected areas are to survive and achieve their objectives, particularly in developing countries in which a significant proportion of such areas are surrounded by impoverished communities.

The Golden Gate study has confirmed that prevailing levels of poverty remain a major problem for large sectors of the communities that border on a protected area. The magnitude of poverty in the rural areas adjacent to national parks highlights the need for conservation benefits to be channelled to such communities, and more generally, for mutually beneficial economic opportunities and arrangements between communities and parks. It is crucial, however, that local people should not entertain overinflated expectations regarding such opportunities - particularly those concerning job creation. Community expectations are raised from the moment that a project activity is undertaken - even more so when it involves employment opportunities, no matter how limited these may be. It is therefore imperative that communities should have realistic expectations of the type of developmental and social benefits that can potentially be derived from their partnership with conservation authorities. The hard reality is that it falls beyond the scope, ability and mission of any protected area significantly to reduce poverty amongst its neighbouring communities. Beneficiaries working on the Golden Gate programme equate the programme's success with its ability to provide employment and improve the ability of the poor to earn a living. While the programme does help to alleviate poverty and improve the quality of life of some households in the target population, the positive impacts of the project remain limited to the beneficiaries and their families who are directly involved in the programme.

This case study has proved that strategically planned and well-focused interventions can nevertheless make huge differences to the livelihoods of impoverished households, albeit on a relatively limited scale. The main strengths of programmes of this nature are probably their ability to increase the health and well-being of the communities surrounding conservation areas and their ability to better the future prospects of beneficiaries and their families. Programme beneficiaries and their dependants experience relief from the direst impacts of abject poverty, and benefit from increased health and well-being, better nutritional status, the ability to pay for their children's education and also their immediate basic needs. Although only a tiny fraction of the community benefitted from direct employment on the Golden Gate programme, the impact on those individuals and their dependants in terms of improved quality of life was tangible and significant. 
Evidence suggests that the transfer of skills to the beneficiaries may facilitate the development of small enterprises that can provide more sustainable alternative livelihoods options to the poor once the beneficiaries have exited the programme. This applies particularly to cases where such enterprises require little financial input and where resources are readily available. The training received by the beneficiaries should be seen as a vital first step towards improving the educational status of the members of poor communities and consequently improving their future employability. The training, skills development and work experience gained through participating in the programme are recognised by beneficiaries as important benefits of the programme. Not only that, beneficiaries duly recognise the impact that the programme has on improving the educational status of their children and other family members. The programme therefore makes a significant contribution towards bettering the educational status of the targeted communities, thereby helping to improve the future prospects of the younger generation. Thus, the impact of the programme may extend well into the future as the beneficiaries' children and dependants are able to improve their own prospects for future employment.

An important condition for the success of any outreach programme of this nature is an efficient and supportive institutional structure. As shown in other studies of this kind and again demonstrated in the case of Golden Gate, the institutional structure should ensure that participation is aimed at the most vulnerable and needy segments, and not hijacked by the elite. Furthermore, the institutional structure should respond to the overall developmental and social needs of the community, and not only to conservation issues. This requires close collaboration between the conservation authority, the local and the district municipalities and even the provincial government. The Golden Gate study made it evident that such collaboration also needs to be strengthened by actively involving stakeholders from the political and the economic spheres in structuring and developing the programme further to enhance the benefits of the programme in targeted communities. In other words, in order to maximise the impact of any poverty-alleviation programme at Golden Gate, it should tie up with and feed into existing poverty-intervention strategies of other institutional stakeholders. Local government, however, should fulfill a coordinating role in such a network of role players and stakeholders, which means that outreach programmes targeting neighbouring communities should not be seen as stand-alone projects, but as complementary to existing development initiatives - particularly initiatives aimed at job creation and income generation.

The impact of national parks and other protected areas on their neighbouring communities particularly poor rural communities in developing countries - is arguably one of the most controversial debates in conservation circles. This debate is intensifying as protected areas in developing nations continue to expand, consequently limiting agricultural development and access to natural resources. Some sectors within the conservation community are increasingly contesting the notion of an integrated development and conservation approach, and argue that the needs and objectives of both agendas cannot be met in a single, integrated and holistic approach without posing major threats to biodiversity protection (Brechin et al., 2007; Upton et al., 2008). Integrated conservation and development programmes can only succeed when stakeholders pool resources, in other words when conservation authorities engage with local and provincial government authorities whose first commitment should be to the delivery of key services to the community. No ICDP 
should be seen as a substitute for government-initiated programmes to mitigate poverty; at best it can supplement such programmes. This is not to say, however, that a national park such as Golden Gate cannot make an important contribution towards reducing poverty levels. Exactly how it should be done, under what conditions, and how the impact can be maximised and sustained need adequately to be researched and documented. This having been said, the following overall lessons and recommendations cascade from the analysis in this chapter:

- Both the opportunities and the limitations of a protected area should be clearly stipulated when it comes to poverty alleviation. To avoid a situation of overinflated expectations and inevitably disillusionment amongst community members, both the type and scale of poverty-mitigation interventions should be communicated explicitly to all stakeholders and affected parties.

- In assessing the contribution of protected areas to the well-being of neighbouring communities, a multidimensional understanding of poverty should be applied to allow for the exploration of the entire range of benefits available from protected areas. When poverty is conceptualised in terms broader than merely the monetary, then specific elements of poverty (reduction) can target the most vulnerable groups, such as women, the elderly, children, etc.

- Strategic, informed and careful segmentation of the neighbouring community, and particularly of the most marginalised and needy groups within the community, is necessary to optimise the distribution and impact of programme benefits. This could require compiling a community profile and regular analysis of the socio-economic dynamics within the community, so as to ensure that benefits from the protected area are indeed channelled to the poorest sectors of the community.

- Strong, integrated and efficient partnerships with local and key stakeholders across different sectors are a prerequisite if any outreach programme - and particularly a poverty relief programme - wishes to maximise its impact among the neighbouring community. A cross-institutional partnership of this nature should involve not only conservation and development agencies, but also democratically elected representatives of the target population in the area.

- Strengthening the impact and efficiency of an outreach programme calls for regular and continuous monitoring and evaluation. In this way, programme weaknesses can be identified and addressed, new opportunities unlocked and potential threats overcome. Open communication and wide publicity of the successes and failures can assist in facilitating a learning environment and contribute to an inventory of bestpractice policies in the wider context of integrated conservation and development initiatives.

\section{Acknowledgment}

The authors wish to thank South African National Parks, and particularly the management of the Golden Gate Highlands National Park, for their support during the field study for this project. Opinions expressed in this chapter, however, are those of the authors and do not necessarily represent either the official policy of SANParks or that of Golden Gate Highlands National Park. 


\section{References}

Algotsson, E. (2006). Wildlife conservation through people-centred approaches to natural resource management programmes and the control of wildlife exploitation. Local Environment, Vol. 11, No. 1, (January 2006), pp. 79-93, ISSN 1354-9839

Alston, M. \& Bowles, W. (2003). Research for social workers: an introduction to methods (2nd Edition), Routledge, ISBN 0-415-30722-8, London

Andam, K.S., Ferraro, P.J., Sims, K.R.E., Healy, A. \& Holland, M.B. (2010). Protected areas reduced poverty in Costa Rica and Thailand. PNAS, Vol. 107, No. 22, (1 June 2010), pp. 9996-10001, ISBN 9990-10001, Retrieved from http://www.pnas.org/cgi/doi/10.1073/pnas.0914177107

Balint, P.J. (2007). A proposed general model for Southern African community-based wildlife management. Human Dimensions of Wildife, Vol. 12, No. 3, (May/June 2007), pp. 169-179, ISSN 1087-1209

Barrow, E. \& Murphree, M. (2001). Community conservation: from concept to practice, In: African wildlife $\mathcal{E}$ livelihoods, Hulme, D., \& Murphree, M. (Eds), pp. 9-23, David Philip, ISBN 0-325-07060-1, Cape Town

Brechin, S.R., Murray, G. \& Benjamin, C. (2007). Contested ground in nature protection: current challenges and opportunities in community-based natural resources and protected areas management, In: The SAGE handbook of environment and society, Pretty, J., Ball, A.S., Benton, T., Guivant, J.S., Lee, D.R., Orr, D., Pfeffer, M.J. \& Ward, H. (Eds), pp. 553-577, SAGE, ISBN 9781412918435, London

Child, B. (2004). Innovation in park management, In: Parks in transition: biodiversity, rural development and the bottom line, Child, B. (Ed.). (2004), pp.165-188, Earthscan, ISBN 1844070697, Sterling

Collins, S. \& Snel, H. (2008). A perspective on community based tourism from South Africa: The TRANSFORM Programme 1996-2007, In: Responsible tourism: critical issues for conservation and development, Spenceley, A. (Ed.), pp. 85 - 106, Earthscan, ISBN 9781844076390, Sterling

De Beer, F. \& Marais, M. (2005). Rural communities, the natural environment and development - some challenges, some successes. Community Development Journal, Vol. 40, No. 1, (January 2005), pp. 50-61, ISSN 0010-3802

Decker, J.D., Raik, D.B., Carpenter, L.H., Organ, J. \& Schusler, T.M. (2005). Collaboration for community-based wildlife management. Urban Ecosystems, Vol. 8, No. 2, (June 2005), pp. 227-236, ISSN 1083-8155

Department of Environmental Affairs (2009). A review of the People \& Parks Programme, Department of Environmental Affairs, Pretoria

Department of Environmental Affairs (2011). People and Parks Programme, In: Department of Environmental Affairs, 24 March 2011, Retrieved from:

http://www.peopleandparks.com/about

Department of Water Affairs (2011). Working for Water, In: Department of Water Affairs, 7 April 2001. Retrieved from: http:/ /www.dwaf.gov.za/wfw/

De Sherbinin, A. (2008). Is poverty more acute near parks? An assessment of infant mortality rates around protected areas in developing countries. Oryx, Vol. 42, No. 1, (January 2008), pp. 26-35, ISSN 0030-6053 
Dudley, N., Mansourian, S., Stolton, S., \& Suksuwan, S. (2008). Protected areas and poverty reduction, World Wide Fund for Nature, ISBN 978-2-88085-279-5, Gland

Fabricius, C., Koch, E. \& Magome, H. (2001). Community wildlife management in Southern Africa: challenging the assumptions of Eden, Russell Press, ISBN 1843690349, Nottingham

Ghimire, K.B. (1995). Parks and people: livelihood issues in national parks management in Thailand and Madagascar, In: Development and environment: Sustaining people and nature, Ghai, D. (Ed.), pp. 195-227, Blackwell, ISSN 0012-155X, Oxford

Guyot, S. (2005). Political dimensions of environmental conflicts in Kosi Bay, South Africa: significance of the new post-apartheid governance system. Development Southern Africa, Vol. 22, No. 3, (September 2005), pp. 441-458, ISSN 0376-835X

Harmon, D. (Ed.). (1994). Coordinating research and management to enhance protected areas. IUCN, ISBN 2-8317-0214-3, Caracas

Hulme, D. \& Murphree, M. (2001). Community conservation as policy: promise \& performance, In: African wildlife \& livelihoods, Hulme, D. \& Murphree, M. (Eds), pp. 280-297, David Philip, ISBN 0325070601, Cape Town

Kothari, A., Anuradha, R.V. \& Pathak, N. (1998). Community-based conservation: issues and prospects, In: Communities and conservation: natural resource management in South and Central Asia, Kothari, A., Pathak, N., Anuradha, R.V. \& Taneja, B. (Eds), pp. 2755, SAGE, ISBN 0761992790, New Delhi

National Department of Health, (2010). National Antenatal Sentinel HIV and Syphilis Prevalence Survey in South Africa, 2009, National Department of Health, Pretoria

Naughton-Treves, L.A., Holland, M.V. \& Brandon, K. (2005). The role of protected areas in conserving biodiversity and sustaining local livelihoods. Annual Review of Environment Resources, Vol. 30, (November 2005), pp. 219-252, ISSN 0065-1346

Nthangeni, M. (2011). Personal correspondence between the first author and the Project Manager: Golden Gate Highlands National Park, February 2011

Pelser, A.J., \& Sempe, A. (2003). Omgewingsbestuur in 'n nuwe era: 'n nis vir die Geesteswetenskappe. Tydskrif vir Geesteswetenskappe, Vol. 43, No. 3\&4, (September/December 2003), pp. 164-176, ISSN 0041-4751

Pelser, A.J. \& Redelinghuys, N. (2008). Towards a 10-year review of the Population Policy implementation in South Africa (1998-2008): Population, Environment and Development, National Department of Social Development, Pretoria, February 2011, Retrieved from:

http://www.population.gov.za/pop_dev/index.php/Policy-+10/

Population Reference Bureau (2009). 2009 World Population Data Sheet, Population Reference Bureau, Washington

Sammy, J. \& Opio, C. (2005). Problems and prospects for conservation and indigenous community development in rural Botswana. Development Southern Africa, Vol. 22, No. 1, (March 2005), pp. 67-85, ISSN 0376- 835X

Simpson, M.C. (2008). The impacts of tourism initiatives on rural livelihoods and poverty reduction in South Africa: Mathenjwa and Mqobela, In: Responsible tourism: critical issues for conservation and development, Spenceley, A. (Ed.), pp. 240-266, Earthscan, ISBN 97811844076390, Sterling 
Simpson, M.C. (2009). An integrated approach to assess the impacts of tourism on community development and sustainable livelihoods. Community Development Journal, Vol. 44, No. 2, (April 2009), pp. 86-208, ISSN 0010-3802

South African Institute of Race Relations (2009). South Africa Survey 2008/2009, South African Institute of Race Relations, ISSN 1027-1724, Johannesburg

South African Institute of Race Relations (2010). South Africa Survey 2009/2010, South African Institute of Race Relations, ISSN 1027-1724, Johannesburg

South African National Parks (SANParks) (2000). Towards best practice: communities and conservation (Conference Proceedings), SANParks, Pretoria

South African National Parks (SANParks) (2011). Golden Gate Highlands National Park, In: SANParks, March 2011, Retrieved from http://www.sanparks.co.za/parks/golden_gate/all.php

Spenceley, A. (2005). Nature-based tourism and environmental sustainability in South Africa. Journal of Sustainable Tourism, Vol. 13, No. 2, pp. 136-170, ISSN 09669582

Spenceley, A. (2006). Eco-tourism: benefits for conservation and local people? African Wildlife, Vol. 60, No. 3, (Autumn 2006), pp. 16-18, ISSN 0002-0273

Spenceley, A. (2008a). Impacts of wildlife tourism on rural livelihoods in Southern Africa, In: Responsible tourism: critical issues for conservation and development, Spenceley, A. (Ed.), pp.159-186, Earthscan, ISBN 9781844076390, Sterling

Spenceley, A. (2008b). Responsible tourism in Southern Africa. In: Responsible tourism: critical issues for conservation and development, Spenceley, A. (Ed.), pp. 1-24, Earthscan, ISBN 9781844076390, Sterling

Summers, R. (1999). Legal and institutional aspects of community-based wildlife conservation in South Africa, Zimbabwe and Namibia. Acta Juridica 1999, pp. 188210, ISSN 0065-1346

Taljaard, J. (2010). Personal presentation by the Park Manager: Golden Gate Highlands National Park, April 2010

Tucker, B. (2010). Clarens leads in dinosaur fossil find. Financial Mail, (1 July 2010), January 2011, Retrieved from http:/ / www.fm.co.za/Article.aspx?id=113520

United Nations Environment Programme (UNEP) (2004). Exploring the links: human wellbeing and ecosystem services, UNEP, ISBN 1-895536-86-3, Nairobi

Upton, C., Ladle, R., Hulme, D., Jiang, T., Brockington, D. \& Adams, W.M. (2008). Are poverty and protected area establishment linked at a national scale? Oryx, Vol. 42, No. 1, (January 2008), pp. 10-25, ISSN 0044-7447

Wells, M.P. \& McShane, T.O. (2004). Integrating protected area management with local needs and aspirations. Ambio, Vol. 33, No. 8, (December 2004), pp. 513-519, ISSN 0044-7447

Working for Wetlands (2010). Working for Wetlands-Golden Gate, March 2011, Retrieved from: http://www.southafricanbiodiversity.co.za/wetlands/164-working-forwetlands-golden-gate-highlands-national-park

World Health Organisation (1997). Nutrition and poverty, ACC/SCN Secretariat, Geneva

World Parks Congress (2003). The Durban Accord, March 2011, Retrieved from: http://cmsdata.iucn.org/downloads/durbanaccorden.pdf 
Zimmerer, K.S., Galt, R.E. \& Buck, M.V. (2004). Globalization and multi-spatial trends in the coverage of protected-area conservation (1980-2000). Ambio, Vol. 33, No. 8, (December 2004), pp. 520-529, ISSN 0044-7447 


\title{
Biodiversity, Ecology and Toxic Principles in Plants - Case Study: Fungal Biocontrol
}

\author{
Cecilia Peluola \\ AAFC, Saskatoon Research Centre, Saskatchewan \\ Canada
}

\section{Introduction}

Plants are made up of simple to complex natural plant derived compounds often referred to as toxic principles in plant. These natural compounds comprise acids, alkaloids, gossypol, glycosides, minerals, proteins, amino-acids, resins, resinoids, unclassified toxins and plants causing mechanical injury (http:// quizlet.com/3348648/toxic-principles-in-plants-flashcards/ 2010). They are valuable components of plants, animals as well as man where they contribute to metabolism, resistance against pests and diseases (Shafique et al., 2011). It has been argued that some purified forms are beneficial in the pharmaceutical world (http://www.blueplanetbiomes.org/amason.htm2009). Biodiversity is defined as the variety of species, their genetic make-up, and natural communities in which they occur. It comprises all native organisms (plants and animals) and the processes that sustain life on earth. It is the variation of life in an area. It can be genetic or ecological. Genetic diversity deals with various genes needed by organisms to survive. On the other hand, ecological diversity is the diversity of all living things within an ecological zone such as rainforest, savannah, desert, arid and semi-arid ecologies (http:/ / www.blueplanetbiomes.org/ amason.htm2009).

Biodiversity is a vital component of an ecosystem. It is found wherever there is life where it maintains oxygen balance in the air, replenishes the soil, purifies water, protects against erosion, flood, acts as wind shield, regulates storm and climate damage. Rapid loss of biodiversity is on the increase, due to demands from growing global population, technology advancement and societal consumption. In response to the above challenge, there have been concerted efforts to explore the environment and to utilise available resources for sustainable development. One of such effort is directed towards biological control (biocontrol) of fungal pathogen. The approach generally utilises living organisms (plants and/or animals) or natural products derived from these organisms called biofungicides. This approach relies on basic principles of plant pathology and disease triangle to achieve fungal control (Bailey, 2004). It employs the principle of Koch postulate, assessment of growth characteristics, site of infections, host range for crop tolerance and efficacy on other pests.In the past, some group of thought believe this approach may not be suitable other than greenhouses and forestry. However, the existence of broad spectrum biofungicides coupled with consumer's attitude towards food safety, synthetic pesticide usage, demand for environmentally friendly biofungicides and preference for organic or certified fungicide-free-produce have made biocontrol appealing (Peluola, et al. 2010, Bailey, 2010). Biofungicides of plant origin is a promising management strategy for a safer and healthier environment (Obi, 1991, Sangoyomi, 2004, Peluola, 2005, Peluola et al., 2007; 2010, Akinbode and Ikotun, 2008, Shafique 
et al., 2011). Their occurrence within genetically similar species may not differ; however, recent researches suggest variations in their potency against fungi pathogens, their morphology and state of their by-products. Further research (Shafique et al.2011) also established the occurrence of these toxic materials in different forms on plants. However, there are fewer researches aimed at examining the possible diversity of toxic principles in plant due to ecological or geographical locations where such plants are found. In order to maximally benefit from arrays of potentials available from plant products, the needs to evaluate promising plant products in relations to ecological zones where they occur is imperative. Proximity to natural ecosystem where such potential biopesticides are found is paramount to sustainable production of active compounds and subsequent utilization for sustainable development. This chapter focuses on the authors' experiences on extraction, bioassay and effectiveness of potential biofungicides across agro-ecological zones in the control of fungal pathogens of arable crop. Judicious application of the complex interaction between ecology, biodiversity and toxic principles in plants is a feasible tool for sustainable management of fungi pathogens.

\section{Diversity of biofungicides of plant origin}

Biofungicides exhibit potential and physical variations (Peluola 2005). Its potential lie in variations in factors necessary to determine its ability to manage or control the target organism. Such factors include variation in fungitoxicity (fungistatic or fungicidal), minimum inhibition concentration, effectiveness or sensitivity to target organism and stability of active component on storage. Mechanisms of action are both physical and biochemical (Bailey, 2010). Fungi pathogens respond in three different ways to treatment with plant metabolites. They are either inhibitory, stimulatory or no effect. Inhibitory effect occurs when the presence of plant metabolites lead to a reduction in growth or complete death of fungal pathogens. Stimulatory lead to an increment in the growth of fungal pathogens above the untreated and no effect is a similar response in growth as in untreated pathogen. In a search for potential biofungicides, twelve tropical plants were evaluated for their fungitoxic effect on some fungal pathogens. The result showed that active components extracted in water were either inhibitory or had no effect. In contrast, ethanol and hexane extracts were stimulatory on the pathogen Colletotrichum destructivum O Gara treated with Parkia biglobosa (L.) leaf extract and Morinda lucida at (-20.0 and $-23.9 \%)$ ethanolic extract and $(-22.0$ and $-66.4 \%)$ hexane extract respectively (Peluola, 2005). On the other hand, physical variation has to do with variation in visual observation, morphology and state of biofungicides.

Biodiversity of biofungicides can be viewed in two dimensions, the intra-specific and interspecific diversity.

\subsection{Intra-specific diversity}

Intra-specific diversity deals with the intrinsic factors that lead to variation in diversity. The following case studies are used to demonstrate intra-specific diversity among some medicinal plants and to understand possible link between ecology, biodiversity and toxic principles in plant.

\subsubsection{Case study 1: Diversity of neem seed oil (Azadirachta indica (A.) Juss) across agro-ecological zones}

In a survey conducted across five savannah agro-ecological zones in Nigeria, West- Africa (Table 1) to determine the physical variations of neem seed oil across the savanna agro- 
ecological zones (AEZs) of Nigeria. Samples were collected from derived savanna (DS) southern guinea savanna (SGS), Northern guinea savanna (NGS), and Arid/semi- arid savanna (ASS) zones of Nigeria occupying about $80 \%$ of Nigeria land. Over $70 \%$ of West African land is situated in the savanna zones. (Isichei and Awodoyin,1990; Awodoyin et al., 1997). Oil yielding capacity of neem seed, colour of oil and neem cake (residue left over after the extraction of oil from neem seed) and physical state of oil were examined. Neem seed oil from savanna AEZs of Nigeria varied in all the parameters observed i.e. (oil yielding capacity, colour and state at $4{ }^{\circ} \mathrm{C}$ ). The highest volume of oil produced per $\mathrm{kg}$ of seed is $276 \mathrm{ml}$ for seeds from Hadejia (ASS) and lowest volume of oil of $142 \mathrm{ml}$ was obtained from Bida (SGS). The trend volume of oil extracted from $1 \mathrm{~kg}$ of seed was as follows: Hadejia (ASS) $276.00 \mathrm{ml}>$ Zaria 270.00ml (NGS) > Ogbomosho (DS) $208.00 \mathrm{ml}>$ Mokwa (SGS) $183.00 \mathrm{ml}>$ Ilorin (DS) $170.00 \mathrm{ml}>$ Kaduna (NGS) $156.00 \mathrm{ml}$ and $>142.00 \mathrm{ml}$ in Bida (SGS) per kilogram of seed (Table 2).Variation observed in the oil may be due to change in climatic factors eg annual rainfall, temperature, soil and humidity as we moved up the Northern parts of Nigeria.

\begin{tabular}{llll}
\hline \multicolumn{1}{c}{ Location } & \multicolumn{1}{c}{ Agro-ecological zones (AEZs) } & \multicolumn{1}{c}{ State } & Collection co-ordinates \\
\hline Oghomosho & Derived Savanna (DS)1 & Oyo & $8^{\circ} 13^{\prime} \mathrm{N}, 4^{\circ} 26^{\prime} \mathrm{E}$ \\
Ilorin & Derived Savanna (DS)2 & Kwara & $8^{\circ} 50^{\prime} \mathrm{N}, 4^{\circ} 55^{\prime} \mathrm{E}$ \\
Mokwa & Southern Guinea Savanna (SGS)1 & Niger & $9^{\circ} 18^{\prime} \mathrm{N}, 7^{\circ} 38^{\prime} \mathrm{E}$ \\
Bida & Southern Guinea Savanna (SGS)2 & Niger & $9^{\circ} 08^{\prime} \mathrm{N}, 7^{\circ} 05^{\prime} \mathrm{E}$ \\
Abuja & Derived Savanna (DS)3 & FCT & $9 \circ 05^{\prime} \mathrm{N}, 6^{\circ} 01^{\prime} \mathrm{E}$ \\
Kaduna & Northern Guinea Savanna (NGS)1 & Kaduna & $10^{\circ} 52^{\prime} \mathrm{N}, 7^{\circ} 44^{\prime} \mathrm{E}$ \\
Zaria & Northern Guinea Savanna(NGS) 2 & Kaduna & $11^{\circ} 11^{\prime} \mathrm{N}, 7^{\circ} 38^{\prime} \mathrm{E}$ \\
Kano & Sudan savanna & Kano & $11^{\circ} 58^{\prime} \mathrm{N}, 8^{\circ} 30^{\prime} \mathrm{E}$ \\
Gumel & Sudan savanna & Jigawa & $12^{\circ} 631^{\prime} \mathrm{N}, 9^{\circ} 38^{\prime} \mathrm{E}$ \\
Hadejia & Sahel savanna & Jigawa & $12^{\circ} 45^{\prime} \mathrm{N}, 10^{\circ} 05^{\prime}$ \\
\hline
\end{tabular}

Where FCT = Federal Capital Territory

Table 1. Agro-ecological zone for the collection of neem seed and leaf samples in Nigeria, West-Africa.

In Nigeria, distinct variation exist across agro-ecological zones especially in respect to annual rainfall (1200-1500mm for southern guinea savanna (SGS) and 300-500mm for Arid and semi-arid savanna (ASS) zones) and length of growing season (7-9 months, for SGS and 3-4months for ASS). This result suggests the importance of drier savanna in the production of neem seed oil. Color of neem seed oil and neem cake also varied by agro-ecology. Neem trees in Nigeria contain abundant oil in the range of $140 \mathrm{ml} / \mathrm{kg}-276 \mathrm{ml} / \mathrm{kg}$ (Table 2) relative to $150 \mathrm{ml} / \mathrm{kg}-200 \mathrm{ml} / \mathrm{kg}$ obtainable in the USA and Asian countries (HDRA, 1999).

\subsubsection{Fungitoxicity and control of seed and soil-borne fungal pathogens of cowpea (Vigna unguiculata (L). Walp) with neem seed oil}

Fungitoxicity test on neem seed oil extracted across the savanna agro- ecological zones (AEZs) of Nigeria were further tested on mycelial growth of Colletotrichum capsici (Syd.) Butler and Bisby) and Macrophomina phaseolina Tassi Goid of cowpea in Nigeria. Biplot was 
employed to access variation and interactions across the AEZs. Interaction and variations among entries and environments and between entries and environments were accessed.

Entries close to the origin possesses an average performance across all the environments, and entries close to each other have similar performance. Small angle between two environments vectors indicates strong positive association (similarities) between two environments. Ninety degree angles indicate no association and angle greater than $90^{\circ}$ represent dissimilar (Hess et al.2002).

On M. phaseolina, neem oil extracted from Ilorin, Ogbomosho (derived savanna) and Mokwa (southern guinea savanna) performed similarly while strong positive association existed between Ogbomosho and Hadejia (Sahel savanna) samples. On C. capsici, samples from Bida (southern guinea savanna) and Ilorin (Derived savanna) were similar (fig 1) (Peluola, 2005; Peluola, et al., 2010).

Neem seed oil from savanna (AEZs) of Nigeria differed significantly in respect of their invitro effects on two cowpea fungal pathogens, Macrophomina phaseolina (Macrophomina blight) and Collectotrichum capsici (brown blotch). Thus, their effects on mycelial growth of the two fungi on APDA as well as their minimum inhibition concentrations and overall rating of efficacy were significantly different from one another. These differences are not attributable to variation in latitudinal location of the seed collection sites since oil extract from seeds collected from Hadejia in Sahel savanna and Oghomosho (in derived savanna) reduced the most the in-vitro radial mycelial growth of both fungi.

\begin{tabular}{llll}
\hline Location / AEZs & $\begin{array}{l}\text { Volume of oil } \\
\text { in ml/Kg neem } \\
\text { seeds }\end{array}$ & Color of oil & $\begin{array}{l}\text { State of oil } \\
\text { at } \mathbf{4}^{0} \mathrm{C}\end{array}$ \\
\hline Ogbomoso (Derived savanna) & 208.0 & Brown & Solid \\
Ilorin (Derived savanna) & 170.0 & Dark golden brown & Solid \\
Mokwa (Southern guinea savanna) & 183.0 & Golden brown & Solid \\
Bida (Southern guinea savanna) & 142.0 & Brown & Liquid \\
Kaduna (Northern guinea savanna) & 156.0 & Golden brown & Liquid \\
Zaria (Northern guinea savanna) & 270.0 & Dark golden brown & Liquid \\
Hadejia (Sahel) & 276.0 & Dark golden brown & Liquid \\
Standard Error & 20 & & \\
C.V. (\%) & 3.6 & & \\
\hline
\end{tabular}

Table 2. Physical variations observed in neem oil extracts from different Agro-ecological zones in Nigeria.

Color characteristics of AEZs oil were based on mycological color identification guide of Rayner (1970).

Neem trees occur abundantly in northern Nigeria. As shade and aesthetic trees, they line many streets in the towns; they are frequently used in shelter belts and as shade trees in farms. Neem trees produce large quantities of seeds that drop and decay, apparently with little or no value to farmers. However, neem seed oil is very easy to produce (HDRA,1999) and it can be produced locally like groundnut oil and used as an effective natural pesticide against pests and pathogens as reported by earlier researchers e.g (Ketkar and Ketkar,1993; 
Ivbijaro,1990;Ivbijaro,1993;Obi,1991;Lale and Abdulrahman,1998). In the present study, there was no clear trend in relationship between the toxicity in vitro of neem seed oil to the two fungi pathogen and latitudinal location of the seed collection sites. For example, the highest toxicity to M. phaseolina was produced by oil extracted from seed collected from Hadejia in Sahel savanna which was followed by oil extracted from seeds collected from Ogbomosho (derived savanna), which both are at two ends of the country from wet to arid environments. Similarly the greatest reduction in mycelial growth in vitro of $C$. capsici occurred in APDA containing oil from neem seeds collected at Hadejia which was followed by oil from seeds collected at Ogbomosho. In this case, however, the next most effective oil extracts were from seeds collected from Kaduna and Zaria, in that order, both located in the northern Guinea savanna. Also, oils from seeds collected at two locations in the southern guinea savanna (Mokwa and Bida) and one location in the derived savanna (Ilorin) have no effect on M. phaseolina. However, they were effective or moderately effective on C. capsici. It appears that the fungal toxicity of oil extracted from neem seeds is location specific and is probably associated with ecotype or variety or strain of neem grown in these environments as suggested by Dales (1996) and Pamplona and Roger (1999).

The report of biplot analysis generally corroborated locational specificity of neem oil at varied concentration tested. This is probably the first report of a study in which fungal toxicity of neem seed oil was related to the geographical location of the trees that produced the seeds. The results suggest that it may be necessary to evaluate the relative efficacy of neem seed oil from different locations in any effort to use the oil as pesticide against specific pathogens (Peluola et al. 2010).

\subsubsection{Benefical effect of neem oil diversity}

Other benefits from the oil such as provision of raw material for industries, neem cake production (good source of urea), soap making, source of income for the poor especially women and change in economic status of rural dwellers can be maximally utilized. Neem oil from derived (DS) and southern guinea savanna zones of Nigeria are solid at $4{ }^{\circ} \mathrm{C}$ while northern guinea savanna (NGS), arid and semi- arid savanna (ASS) are liquid. Similarly, as we move from the southern zones to the northern Nigeria, color of oil produced per AEZs varied from greyish Sepia (DS) to Sepia and Cinnamon (SGS), Umber to Fuscous black (NGS) and dark slate blue (ASS). According to Dales, (1996); Pamplona and Roger, (1999), differences in trees may be due to genetic components or environments where they are found. The interzonal variations may be due to closeness in physical and environmental factors within the AEZs such as rainfall, relative humidity, temperature and soil type or genetic differences among neem trees. However, this study brings out the inter- zonal relationship and differences in neem seed oil across the savanna AEZs of Nigeria. It also identify agro- ecological zones of higher oil yielding capacity from neem seed. This information will be relevant to agro-allied company and industries of areas where maximum raw materials for their production are available. Decision on suitable site for the establishment of biopesticide industry in order to promote low cost but sustainable large scale production can be achieved.

\subsection{Case study 2: Diversity of neem leaf extracts as potential biofungicdes for the control of anthracnose disease of cowpea (Vigna unguiculata (.L). Walp)}

In a similar survey carried out to determine the variation in the fungitoxicity and effectiveness level of aqueous and ethanol neem leaf extract from savanna agro- ecological zones (AEZs) viz: derived savanna (DS 1, and 2), Southern guinea savanna (SGS 1, 2 and 3), Northern guinea 
savanna (NGS 1 and 2), Sudan savanna (SDS 1and 2) and Sahel savanna (SHS) zones of Nigeria. Graded extracts at concentration of 0, 5, 10, 25 and 50\% were tested on Colletotrichum destructioum for fungitoxicity and effectiveness levels as highly, effective, moderately, slightly and not effective across AEZs. Data were subjected to ANOVA. Ethanol extract significantly (P $\leq$ 0.05) reduced growth than aqueous extract across both concentration and locations. Effectiveness level of extracts were slightly to highly effective and significant $(\mathrm{P} \leq 0.05)$ across concentrations and locations. Growth inhibition of ethanol leaf extract ranged from $39.0 \%$ (SGS 1) to $64 \%$ (SHS 1) relative to $8.13 \%$ (NGS1) and 64\% (SGS 2 and SHS) aqueous.The percentage reduction in radial growth of $C$. destructioum produced by ethanol extract of neem was consistently superior to that of aqueous extracts across all locations and concentrations except for Sahel savanna and southern guinea savanna 2. Although the minimum effective concentration of both ethanol and aqueous leaf extracts were the same, ethanol extract of the leaf from eight of the ten locations were rated as highly effective compared to only three locations for the aqueous extract. These observations suggest that ethanol is a better extractor of fungitoxic substances of neem leaves than water. This agreed with the report of Lale and Abdulrahaman (1998), who showed that ethanol extracted more potent insecticidal components of either neem seed or seed oil than aqueous or hexane extracts.

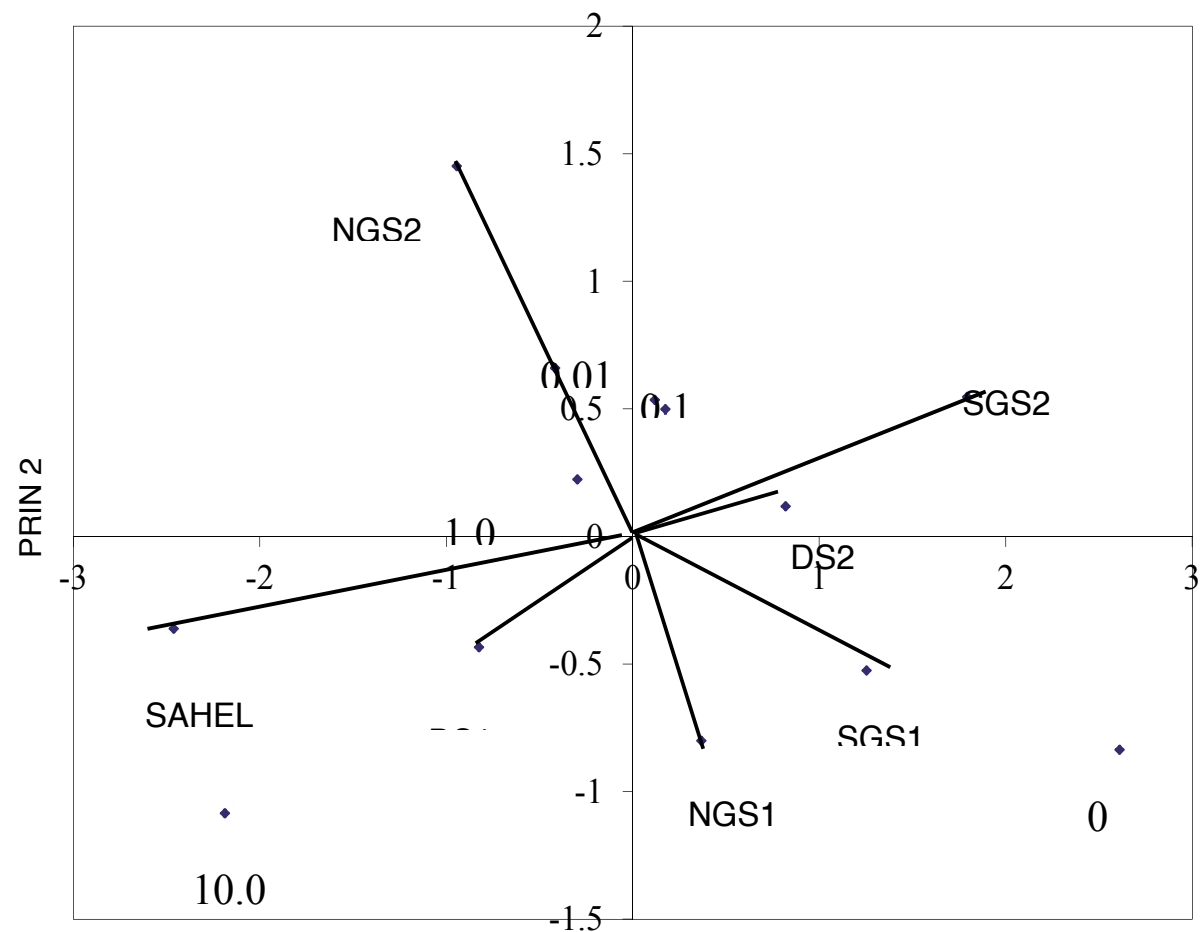

PRIN 1

Where PRIN= Principal component; DS= Derived savanna 1\&2; NG= Northern guinea savanna $1 \& 2$; SGS=Southern guinea savanna1\&2;

Fig. 1. Biplot showing the relationship between neem seed oil extracted from different location in the savanna AEZs of Nigeria at different concentration. 


\begin{tabular}{lllllll}
\hline Locations/ conc ${ }^{n}(\%)$ & 0.01 & 0.1 & 1.0 & 10.0 & $\mathrm{MIC} \%)$ & $\begin{array}{l}\text { Level of } \\
\text { Effectiveness }\end{array}$ \\
\hline Ogbomosho & 0 & 0 & 3.7 & 25.9 & 1.0 & $(\mathrm{ME})$ \\
Ilorin & 0 & 0 & 0 & 0 & $\mathrm{NA}$ & $(\mathrm{NE})$ \\
Mokwa & 0 & 0 & 0 & 0 & $\mathrm{NA}$ & $(\mathrm{NE})$ \\
Bida & 0 & 0 & 0 & 0 & $\mathrm{NA}$ & $(\mathrm{NE})$ \\
Kaduna & 0 & 0 & 0 & 0 & $\mathrm{NA}$ & $(\mathrm{NE})$ \\
Zaria & 0 & 0 & 0 & 24.1 & 10.0 & $(\mathrm{ME})$ \\
Hadejia & 0 & 0 & 19.6 & 33.3 & 1.0 & $(\mathrm{ME})$ \\
Overall mean & 0 & 0 & 23.3 & 83.3 & & \\
Standard Error & 0 & 0 & 2.76 & 5.71 & & \\
CV & 0 & & 31.36 & 18.14 & & \\
\hline
\end{tabular}

Values are means of three replicate plates per treatment per pathogen. Where MIC $=$ minimum inhibition concentration, $\operatorname{conc}^{\mathrm{n}}(\%)=$ Percentage concentration of oil extract, NE=Not effective; $\mathrm{ME}=$ Moderately effective;

Table 3. Percentage inhibition of radial growth of the M. phaseolina treated with oil extracts from different agro ecological zones.

\begin{tabular}{lllllll}
\hline Locations/concn (\%) & 0.01 & 0.1 & 1.0 & 10.0 & $\mathrm{MIC}(\%)$ & $\begin{array}{l}\text { Level of } \\
\text { Effectiveness }\end{array}$ \\
\hline Ogbomosho & 39 & 36.2 & 36.7 & 66.1 & 0.01 & $(\mathrm{HE})$ \\
Ilorin & 15.2 & 21.6 & 37.3 & 43.5 & 0.01 & $(\mathrm{EE})$ \\
Mokwa & 23.7 & 23.7 & 28.2 & 37.3 & 0.01 & $(\mathrm{ME})$ \\
Bida & 16.7 & 23.2 & 37.9 & 44.1 & 0.01 & $(\mathrm{EE})$ \\
Kaduna & 20.5 & 35.6 & 37.9 & 65.3 & 0.01 & (HE) \\
Zaria & $\mathrm{ND}$ & 45.8 & 55.4 & 54.8 & $\mathrm{ND}$ & $(\mathrm{EE})$ \\
Hadejia & 23.8 & 35 & 50.3 & 74.6 & 0.01 & (HE) \\
Overall mean & 138.9 & 221.1 & 283.7 & 385.7 & & \\
Standard Error & 16.80 & 25.52 & 32.65 & 44.45 & & \\
CV & 32.00 & 30.54 & 30.45 & 30.49 & & \\
\hline
\end{tabular}

Values are means of three replicate plates per treatment per pathogen. Where MIC = Minimum inhibition concentration., $\operatorname{conc}^{\mathrm{n}}(\%)=$ Percentage concentration of oil extract NE=Not effective; $\mathrm{ME}=$ Moderately effective; $\mathrm{EE}=$ Effective; $\mathrm{HE}=$ Highly effective;

Table 4. Percentage inhibition of radial growth of the C.capsici treated with oil extracts from different agro ecological zones.

Regardless of the extracting medium, there were significant differences in the toxicity of leaf extracts to $C$. destructivum. However, neem leaf extract toxicity to the pathogen did not show the agro-ecological zones of the sites from which the leaves were collected. Thus although, across concentrations leaves from southern guinea savanna 2 had the highest toxicity, similar extracts from southern guinea savanna 1 had the least but two toxicity. In respect of 
the aqueous extract, the most efficacious extract across concentration was obtained from leaves collected from Hadejia (Sahel savanna) and in southern guinea savanna which are two contrasting agro-ecological zones especially in respect to annual rainfall $(1200-1500 \mathrm{~mm}$ for southern guinea savanna and 300-500 mm for Sahel savanna) and length of growing season (7-9 months, for southern guinea savanna and 3-4months for Sahel savanna). Since the neem in vitro result of the present study suggests that leaf extract toxicity to $C$. destructioum is probably location specific, leaves for extraction should be collected from sites where leaves gave the highest toxicity, depending on the extraction medium.

\subsection{Case study 111: Comparative efficacy studies across agro-ecological zones on neem seed oil, aqueous and ethanol leaf extracts for control of brown blotch pathogen}

Efficacy studies among neem seed oil, aqueous and ethanol leaf extract were carried out with Colletotrichum capcisi causal organism of brown blotch of cowpea. Graded extracts of aqueous, ethanol and oil extracts were tested from the samples at varied concentrations. The effects of extracts were observed on mycelial radial growth and conidial germination of Colletotrichum capsici, causal organism of brown blotch disease of cowpea in Nigeria. Neem products inhibited the growth of Colletotrichum capsici above 50\% across all agro-ecology in savanna zone of Nigeria in this study. Efficacy of the extract was significantly different at $\mathrm{P}<0.001$. There are indications of higher toxicity to the pathogen as minimum inhibitory concentrations of mycelial growth were observed at lowest concentration tested. This observation is in agreement with Owolade et al. (2003) who observed that neem leaf extract, reduce the incidence of Fusarium moniliforme Sheld on maize seeds. Peluola et al. (2007) also observed that neem leaf extract effectively inhibited the growth of Colletotrichum destructivum in- vitro.

\begin{tabular}{lllllll}
\hline $\begin{array}{l}\text { Location/conc } \\
(\%)\end{array}$ & 5 & 10 & 25 & 50 & MIC(\%) & $\begin{array}{l}\text { Level of } \\
\text { effectiveness }\end{array}$ \\
\hline Oghomosho & 40.9 & 48.4 & 59.7 & 64 & 5 & HE \\
Ilorin & 30.6 & 38.7 & 40.9 & 53.8 & 5 & $\mathrm{EE}$ \\
Mokwa & 29.6 & 32.8 & 45.2 & 49.5 & 5 & $\mathrm{EE}$ \\
Bida & 51.6 & 53.2 & 59.1 & 71.5 & 5 & $\mathrm{HE}$ \\
Abuja & 48.4 & 47.3 & 59.1 & 80.1 & 5 & $\mathrm{HE}$ \\
Kaduna & $\mathrm{ND}$ & $\mathrm{ND}$ & 62.9 & 71.5 & $\mathrm{ND}$ & $\mathrm{HE}$ \\
Zaria & 32.3 & 38.2 & 76.3 & 96.2 & 5 & $\mathrm{HE}$ \\
Kano & 53.8 & 60.2 & 65.6 & 76.9 & 5 & $\mathrm{HE}$ \\
Gumel & 14.5 & 50.5 & 55.4 & 67.7 & 5 & $\mathrm{HE}$ \\
Hadejia & 51.6 & 53.2 & 59.1 & 71.5 & 5 & $\mathrm{HE}$ \\
Overall mean & 35.3 & 42.3 & 58.3 & 70.3 & & \\
SE & 4.2 & 2.8 & 3.1 & 4.2 & & \\
\hline
\end{tabular}

Values are means of three replicate plates per treatment per pathogen. Where MIC = minimum inhibition concentration, $\operatorname{conc}^{\mathrm{n}}(\%)=$ Percentage concentration of leaf extract $\mathrm{NE}=$ Not effective; $\mathrm{ME}=$ Moderately effective; $\mathrm{EE}=$ Effective; $\mathrm{HE}=$ Highly effective;

Table 5. Percentage inhibition of radial growth of the C.destructivum treated with ethanol neem leaf extracts from different agro ecological zones. 
Neem leaf extracts (aqueous or ethanol) compared favourably well with their seed oil counterparts at $10 \%$ extract concentrations (Table 6). Effectiveness levels appear to be location specific, especially at lower concentrations. For example, derived savanna1 was slightly effective (SE) 1-20\% inhibition in aqueous leaf extract, effective (EE) $41-60 \%$ inhibition in ethanol and highly effective (HE) above $60 \%$ inhibition in seed oil extract at $10 \%$ extract concentration. However, effectiveness levels in derived savanna 2 was all effective (EE) $41-60 \%$ inhibition across aqueous and ethanol leaf extract and seed oil extract while Sahel savanna gave highly effective (HE) above $60 \%$ inhibition on the pathogen at $10 \%$ neem extract concentration (Table 6). At higher concentrations of 25 and $50 \%$ leaf extract, aqueous and ethanol leaf extracts gave higher inhibitions above $60 \%$ inhibition on the pathogen. However, ethanol neem leaf extract was not significantly different from aqueous neem extract in toxicity to the pathogen. According to Obi, (1991) and Lale and Abdulrahaman (1998), synthetic solvents are better extractor of bio-active component in plant materials. Effectiveness level at these concentrations ( 25 and $50 \%$ ) were all highly effective (HE) above $61 \%$ inhibition with the exception of derived savanna 2 which was effective (EE) at $41-60 \%$ inhibition. Hence, aqueous extracts are economically viable and recommended for use at farm level due to its reduced cost. Minimum inhibition concentration (MIC) showed that neem leaf extract inhibited the growth of the pathogen at the lowest concentrations ( $5 \%$ neem leaf and $0.01 \%$ seed oil extract) tested. The drier savanna (The Sahel) consistently gave higher inhibition of growth on the pathogen when tested in neem seed oil, aqueous or ethanol neem leaf extract in this study (Table 6). This might be due to reduced volume and number of rainy days per year in the far north compared with the south annual rainfall $(1200-1500 \mathrm{~mm}$ for southern guinea savanna and 300-500mm for Sahel savanna) and subsequent length of growing season (7-9 months,

\begin{tabular}{lllllll}
\hline $\begin{array}{l}\text { Locations /concentration } \\
(\%)\end{array}$ & AQ & LE & ET & LE & SOE & LE \\
\hline Oghomosho & 10 & & 10 & & 10 & \\
Ilorin & 9.6 & SE & 42.9 & EE & 66.1 & HE \\
Mokwa & 49.2 & EE & 44.1 & EE & 43.5 & EE \\
Bida & 79.7 & HE & 40.7 & EE & 37.3 & ME \\
Abuja & 78.0 & HE & 76.3 & HE & 44.1 & EE \\
Kaduna & 24.3 & ME & 45.2 & EE & ND & ND \\
Zaria & 27.7 & ME & 51.4 & EE & 65.3 & HE \\
Kano & 35.0 & ME & 27.7 & ME & 54.8 & EE \\
Gumel & 39.0 & ME & 55.4 & EE & ND & ND \\
Hadejia & 45.2 & EE & 63.3 & HE & ND & HE \\
Overall mean & 79.7 & HE & 76.3 & HE & 74.6 & HE \\
Standard Error & 46.6 & & 52.3 & & 55.1 & \\
\hline
\end{tabular}

Values are means of three replicate plates per treatment. Where LE= Level of effectiveness; $\mathrm{SOE}=$ Seed oil extract from neem; $\mathrm{ET}=$ Ethanolic neem extract; $\mathrm{AQ}=$ aqueous neem extract; NE=Not effective (-0); SE= Slightly effective (1-20\%); ME=Moderately effective (21-40\%); $\mathrm{EE}=$ Effective $(41-60 \%) ; \mathrm{HE}=$ Highly effective $(61-100 \%)$

Table 6. Comparative inhibition \% of radial growth of $C$.capsici treated with aqueous, ethanol, or neem seed oil extracts at $10 \%$ neem extracts concentrations from different agro ecological zones. 
for southern guinea savanna and 3-4months for Sahel savanna. Hence concentrated sap of neem trees in the north acted in synergy to increase toxicity of neem products above other agro-ecologies in the savanna of Nigeria. The result therefore suggests Sahel savanna as better location for producing neem based organic pesticides. It also suggests $25 \%$ concentration of aqueous neem extract across all agro-ecologies for use by the peasant farmers. It is well documented that neem products are effective against certain diseases of plant and animals across the globe (Neem Tree Farms, 2005, White, 2004, NRC, 1992). However, its activity against plant diseases across wider agro-ecology in its natural habitat will be very important for policy / decision makers, industrialists, large scale and peasant farmers in the area of maximizing profit from their farm produce. This result indicates that toxicity and control of fungi pathogens with biopesticides depend on location of extraction, extracting medium and the pathogen under control. However, the importance of diversity across a range of agro-ecology is evident in these studies.

\section{Inter-specific biodiversity and fungal biocontrol}

Biodiversity can also be explained as diversity among species of the same plant. Nature's provision is such that plant occurs in different forms within the plant family. Such is referred to as plant species diversity. Diversity within plant species can be observed in the physical (color, taste, size of development, and other agronomic characteristics) or on its active component. For example, garlic, (Allium sativum) is widely grown and consumed globally. It is believed to have antimicrobial and antifilaria potencies. Traditionally, A. sativum has been used in the treatment of worms and dysentery in children and adults. In the kitchen, garlic is used for seasoning. There are several varieties of garlic but the most popular ones are the common white and the common pink (Ngeze, 2001). In order to verify antifungal potentials of garlic; extracts from common pink and common white garlic were tested on mycelial radial growth, spores, and sclerotial production of Macrophomina phaseolina (Tassi) Goid, Colletotrichum destructivum $\mathrm{O}$ gara and C. capsici (Syd) Butler and Bisby pathogens of cowpea in-vitro.

At 4 days after inoculation, the in-vitro result gave $100 \%$ inhibition on the mycelial, conidial and sclerotial germination of pathogens treated with both pink and white garlic extracts. However, at 5 days after inoculation, pink or white garlic extracted in ethanol generally gave reduced inhibition relative to their aqueous garlic extracts till seven days after inoculation. Media treated with white garlic extracts and inoculated with $M$. phaseolina gave highest inhibition percentages of 91.5 and $82.6 \%$ in aqueous and ethanol garlic extracts respectively relative to the control plate at highest concentration of 250ppm(Table 7).

Similarly, media treated with common pink garlic and inoculated with $M$ phaseolina gave highest reduction of mycelial growth of 72.0 and $65.1 \%$ respectively on aqueous and ethanol pink garlic extract after 7 days of inoculation. The least percentage inhibition of $27.7 \%$ was observed on $C$. capsici when treated with the common pink garlic while the white variety showed its least inhibition percentage of $34.45 \%$ on $C$. destructivum. The result on $M$. phaseolina was not significantly different at $\mathrm{P} \leq 0.05$ and compared favorably with conventional fungicide benomyl at $0.5 \mathrm{gai} / \mathrm{kg}$ (recommended concentration rate).

The fact that white garlic extract consistently prove more effective at inhibiting the mycelial growth of the three cowpea pathogens than the pink garlic is an indication of variation in active constituent due to the existing garlic varieties.

Garlic extracts effectively inhibited the mycelial growth, conidial and sclerotial germination of the three pathogens in vitro. This observation agreed with the work of Sangoyomi (2004) 


\begin{tabular}{|c|c|c|c|c|c|}
\hline \multirow[t]{2}{*}{ Pathogen } & \multicolumn{2}{|c|}{ Pink Garlice } & \multicolumn{2}{|c|}{ White Garlice } & \multirow[t]{2}{*}{ Benomyl } \\
\hline & Aqueous & Ethanol & Aqueous & Ethanol & \\
\hline M. phaseolina & $72.0 \mathrm{a}$ & $65.1 \mathrm{a}$ & $91.5 \mathrm{a}$ & $82.6 a$ & $90.0 \mathrm{a}$ \\
\hline C. destructivum & $36.0 \mathrm{~b}$ & $34.2 b$ & $41.5 b$ & $33.39 b$ & $100.0 \mathrm{a}$ \\
\hline C. capsici & $22.0 c$ & $27.7 \mathrm{c}$ & $54.1 \mathrm{a}$ & $34.45 b$ & $100.0 \mathrm{a}$ \\
\hline
\end{tabular}

Values are means of three replicate plates per treatment. Where M. phaseolina=Macrophomina phaseolina, C. destructioum $=$ Colletotrichum destructioum \& C. capsici $=$ Colletotrichum capsici, Garlice $=$ garlic extract

Table 7. Percentage inhibition of growth of three fungal isolate due to treatment with pink or white garlic extract and compared with benomyl.

who reported that aqueous extract of garlic effectively inhibited mycelia growth, conidia, pycnidia and sclerotial production of Butryodiplodia theobromae, Aspergillus niger, Sclerotium rolfsii, Rhizoctonia solani, and Nattrassia mangifera, fungal pathogens of yam in storage. Ismail et al., (2001) reported the control of Colletotrichum sp and M. phaseolina in jute using garlic extract at ratio 1:2. The result suggests common white garlic extracts a suitable biofungicide against cowpea fungal pathogens. It also explains the inter-specific biodiversity among the garlic spp. Further research may need to look into on-field trial of the spp before embarking on large scale production of the active constituents as biopesticide.

\section{Eco-biodiversity and sustainable agriculture}

In the classical examples on fungal biocontrol discussed above, it is evident that the role of ecobiodiversity in sustainable agriculture is significant in the search for sustenance of individual within and across her agro-ecology. Lately many products from neem (Azadiractha indica (A). Juss) had been patented for use in the developing and developed world (White 2004, Dales 1996 and NRC, 1992). In human medicine, its twigs have been used for the treatment of teeth disease and as a popular traditional remedy against malaria an endemic disease in the tropic. Every parts of the plant in the crude and refined forms had received much attention. The seed oil has been used as remedy against several pests and diseases of plant as insecticidal, fungicidal, nematocidal and bactericidal among others (HDRA 1999; Lale and Abdulrahaman, 1999; Onalo, 1999; Ketkar and Ketkar 1993; Saxena, 1993; Ivbijaro, 1990). The active ingredients found in neem seed oil are mostly the triglycerides i.e. oleic, stearic, and palmitic acids (Saxena, 1993) and are just like ordinary vegetable oil (National Research Council, 1992). Therefore it can serve as essential raw material in the pharmaceutical, agro-allied, soap and detergent industries among others. Products from neem are natural, biodegradable, environmentally friendly, less toxic and leave no residue in the environment. It is of tropical origin and popularly known for its risk-free effect to beneficial microorganisms. The safety of neem derivatives to beneficial microorganism, rapid biodegradability and soft mode of action makes it an appropriate biopesticide. Biotechnology and biological science research council (BBSRC) is an international organisation that deals with different aspects and innovations in biological research. The body recognises four levels of biodiversity as molecular, gene and genome, organism and habit and ecosystem diversity. Habitat and ecosystem diversity can be viewed in a similar context with ecological diversity which is the variation in species within and between different habitats and ecosystems. Phylogeny believes that all diversities are related through common ancestry. Nature is endowed with array of blessings necessary to meet man's sustainable needs within a location. Interference by man and the challenge of 
meeting the needs of increasing population led to huge depletion of natural resources. For example, it is reported that human activities increased extinction rate 1000 times its usual rate (www.pabiodiversity.org/what is biodiversity .html). Exploitation of our environment must be carefully done to prove our understanding of how management affects the ecology. The need to identify what is available, researches its usefulness and identifies strategies of managing and preserving them is important. For example, a particular specie is identified as prevalent in an ecological zone, there is much likelihood that the plant had survived competition from other plants species for it to remain dominant and to sustain dominance within its ecology. Ideally, local uses of such plant might have existed, further research meant to explore other benefits associated with plants capitalizing on their ability to survive competition and exploiting the value of functional biodiversity in sustainable agricultural context will be important.

BBSRC also identify as part of their main objectives the need to uunderstand the ecological significance of intra-specific variation and inter-relationships between inter- and intraspecific variation, investigating biodiversity processes in relation to different land-use patterns and different agricultural systems and also making efforts at conserving habitat and ecosystem diversity.

\section{Conclusion}

Agro-ecological methods, including organic farming practices, can help farmers protect natural resources and provide a sustainable alternative to costly industrial inputs.Agriculture can address environmental challenges, past approaches to combat hunger have tended to focus narrowly on a few types of crops, rely heavily on chemical fertilizers and ignore women farmers. Agricultural practices that emphasize increased production have contributed to the degradation of land, soil, and local ecosystems, and ultimately hurt the livelihoods of the farmers who depend on these natural resources.

'Moving Eco-agriculture into the Mainstream' was one of the 15points recommended by World Watch Institute's on Nourishing the planet team during this year earth day (April 18, 2011). In this era of global climate change and economic recession, the emphasis should be toward ecological agriculture as a means of generating both economic value and sustainable development (World Watch Institute, 2011). A global approach towards ecological agriculture utilizing the nature's provision within or across ecosystem is a move in the right direction. In a similar approach, recently, the United Nations Industrial Development Organisation (UNIDO) has embarked on a major initiative to promote appropriate low-cost, but sustainable technologies and techniques for large scale production of biopesticides from neem in West Africa (UNIDO, APRIL 2007, unpublished information). However, this is probably the first report of a study in which the fungitoxicity of botanicals were related to sites of collection across a wider range of agro-ecological zones.

\section{Acknowledgement}

The author is grateful to the International Institute of Tropical Agriculture (IITA) Nigeria for financial support for this research work. The work is part of doctoral research of the author.

\section{References}

Akinbode O. A. \& Ikotun T. (2008).Efficacy of certain plant extracts against seed-borne infection of Collectotrichum destructioum on cowpea (Vigna uniguculata) African 
Journal of Biotechnology Vol. 7 (20), pp. 3683-3685, 20 October, 2008.Available online at http:/ / www.academicjournals.org/AJB

Awodoyin, R.O., B. A Adelaja, \& O .A Denton (1997). Vitellaria paradoxa in the farming systems of Nigeria humid savanna. Conference proceedings, Forestry Association of Nigeria 227-233pp

Bailey, K.L (2004) Microbial Weed Control: an Off-beat Application of Plant Pathology. Can.J. Plant Pathol. 26:239-244).

Bailey, K.L (2010) Canadian Innovations in Microbial Biopesticides. Can J. Plant pathol. 32(2):113-121.

Dales, M. J. (1996). Azadiractha indica; The neem tree in a review of plant materials. Physiological Plant Pathology 4:477-488.

Freeman, F. \& Y. Kodera (1995). Garlic chemistry: Stability of S-(2-Propenyl)-2-propene-1sulfinothionate (allicin) in blood, solvents, and stimulated physiological fluids. Journal of Agriculture, Food and Chemistry 43: 2332-2338.

Hess D.E, R. Bandyopadhyay \& I. Sissoko, (2002). Pattern analysis of sorghum genotype X environment interaction for leaf panicle and grain anthracnose in Mali. Plant Disease 86: 1374-1382.

Isichei A. O. \& R.O Awodoyin. (1990). Nutrient content and perfomance of the herbaceous legume Tephrocia bracteolata in relation to the grass Andropogon tectorum in both natural habitat and pot culture in South -Western Nigeria. Tropical Ecology 31(2):11-22.

Islam S.M.A, I. Hossain, G.A Fakir \& M. Asad-Ud-Doullah (2001). Effect of physical sorting, seed treatment with garlic extract and Vitavax -200 on seedborne fungal floral and seed yield of jute (Corchorus capsularis L). Parkistan Journal of Biological Information. 4 (12):1509-1511.

Ivbijaro, M.F. (1990). The efficacy of seed oils of Azadirachta indica A. Juss and Piper guineense Schum and Thonn on the control of Callosobruchus maculatus. Insect science and its application, 11 (20): 149-152.

Ivbijaro, M.F. (1993). Toxicity of neem seed, Azadirachta indica A. Juss to Sitophilus oryzae (L) in stored maize. Protection Ecology 5:353-357

Ketkar C.M. \& M.S. Ketkar, (1993) Versatile Neem. A source for Plant Protection In Proc. Symp. Botanical Pesticides in IPM, Rajahmundry 1990. Pp 1-24

Lale, N.E.S \& H .J. Abdulrahaman.(1999). Evaluation of neem (Azadiractha indica A.Juss) seed oil and neem powder obtained by different methods for the management of Callosobruchus maculates (F) (Coleoptera: Bruchidae) in stored cowpea J. of stored products research, vol. 35 (2) 135-143

National Research Council (1992). Neem: A tree to solve global problems National academic press, Washington, D.C.141pp

Neem tree farms (2005). Retieved online www.neemtreefarms.com accessed July 2005.

Ngeze, P.B. (2001). Learn how to grow Onions, Garlic and Leeks. Acacia Stantex Publishers Muthithi road, Westlands, Nairobi. Kenya.22 pp

Obi V. I. (1991). Evaluation of extracts from four locally occurring plants for their fungicidal effects on cowpea anthracnose pathogen - Colletotrichum lindemuthianum. M sc thesis, Dept. of Agric Biololgy, University of Ibadan, Ibadan, Nigeria. 53pp

Onalo, J.I. (1999). Non-chemical control of the yam nematode Scutelonema bradys. Department of Crop Protection and Environmental Biology Ph.D Thesis, University of Ibadan, $172 \mathrm{pp}$. 
Owolade O.F., A.N. Amusa \& Y. O. K Osikanlu, (2000). Efficacy of certain indigenous plant extracts against seed - borne Infection of Fusarium moniliforme on maize (Zea mays L.) in south western Nigeria. Cereal Research Communication. Vol 28: No3, 323 - 327.

Pamplona G.O \& M.D. Rogers (1999). Encyclopedia of medicinal plants. Education and Health library by editorial Safeliz S, .L. Aravaca, 8128040 Madrid (Spain) Vol 1. 398pp

Pennsylvania Biodiversity partnership. What is biodiversity. www.pabiodiversity.org/what is biodiversity.html accessed Dec 2010

Peluola Cecilia .O. (2005). Evaluation of botanicals and microbial bioagents for the control of some fungal pathogens of cowpea (Vigna unguiculata L.Walp). Ph.D thesis, Department of Crop Protection and Environmental Biology, University of Ibadan , Nigeria.I67pp

Peluola Cecilia .O. Emechebe Alphonse.M, Fadina Olubunmi .O. \& Ikotun Babatunde (2007). Evaluation of Neem Leaf extracts (Azadirachta indica (A.) Juss) From Five AgroEcological Zones of Nigeria for Toxicity to Cowpea Anthracnose Pathogen. Proceeding of International Conference on Adaptive Science and Technology (ICAST) Vol (1) 131-135, Dec 10-13 2007 Accra,Ghana West Africa.

Peluola Cecilia .O., Fadina Olubunmi O. \& Emechebe Alphonse .M. (2009). Physical Variations of Neem Seed-oil from Savanna Agro-ecologies of Nigeria. Journal of Science Association of Nigeria. Special 50th anniversary edition (SAN); In press

Peluola Cecilia .O., Fadina Olubunmi O., Ikotun B. \& Alphonse .M Emechebe (2009) Comparative Fungitoxicity of Neem Leaf Extracts and Seed Oil from Five Agroecological Zones in Nigeria. Njala Journal of Agriculture, Science and Technology (NJAST) Vol 2 Freetown, Sierra Leone In press.

Peluola Cecilia .O., Fadina Olubunmi O. \& Emechebe Alphonse .M. (2010) In Vitro Toxicity of Oil Extracted from Neem Seeds Collected from Different Locations Across Savanna Agro-Ecological Zones of Nigeria on Seed and Soil-Borne Pathogens of Cowpea (Vigna unguiculata L.Walp) Achieves of phytopathology and plant protection Vol (1)1-9 2010.

Peluola Cecilia, Fadina Olubunmi. \& Emechebe Alphonse (2010). Management of Foliar and Soilborne Pathogens of Cowpea (Vigna unguiculata (L) Walp) with Two Garlic Varieties (Allium Sativum A.Linn). Journal of medicinal plant research (JMPR) In press

Rayner, R.W (1970). A mycological color chart. Commonwealth Mycological Institute Kew, Surrey, $34 \mathrm{pp}$

Sangoyomi, T.E. (2004). Post-harvest fungal deterioration of yam (Dioscorea rotundata Poir) and its control. PhD thesis, University of Ibadan Nigeria. 180pp

Saxena, R.C. (1993) Neem as a source of natural insecticides - An update. In Proc. Symp. Botanical Pesticides in IPM, Rajahmundry 1990. Pp 1-24

Shazia Shafique, Sobiya Shafique, Rukhsana Bajwa, Nosheen Akhtar \& Sana Hanif (2011) Fungitoxic activity of aqueous and organic solvent extracts of Tagetes erectus on phytopathogenic fungus- Ascochyta rabiei Pak.J.Bot.,43 (1): 59-64

The Henry Doubleday Research Association (HDRA) (1999). The Neem Tree adopted by the Ghana Organic Agriculture Network (GOAN) 15pp.

Toxic principles in plants flashcards/quizlet(http:// quizlet.com/3348648/toxic-principlesin-plants-flash-cards/ 2010).

World watch press release (2011). Innovation that nourish the planet. Agriculture: Unlikely earth day hero. World watch press release April 18th, 2011.www.worldwatch.org, accessed April 21, 2011

What is biodiversity (http:/ / www.blueplanetbiomes.org/amason.htm2009 


\title{
The Potential of Biodiversity in the Andean Region: Use, Conservation and Regulations
}

\author{
Ingrid Schuler G. ${ }^{1}$, Elizabeth Hodson de Jaramillo ${ }^{1}$ and \\ Luis Antonio Orozco C.2,3 \\ ${ }_{1}^{1}$ Pontificia Universidad Javeriana \\ ${ }^{2}$ Universidad Externado de Colombia \\ ${ }^{3}$ STEPS University of Twente \\ 1,2Colombia \\ ${ }^{3}$ The Netherlands
}

\section{Introduction}

Biodiversity has paramount importance for the social, cultural and economic development of humankind, making part of the national heritage of each country and representing enormous environmental, cultural and economic values. As population grows, the demand for freshwater, food and energy resources risks environmental sustainability. Biological resources represent a huge potential, insufficiently exploited, that requires strengthening and applying scientific and technological progress aimed to understand, characterize and use these resources for the benefit of local communities. Technologies and the way in which we should use them are a growing challenge, and problems related to governability, social organization and human rights are of increasing importance in achieving sustainable results (Hodson, 2009). Some ecosystem services that benefit society are air quality, climate (both global and local $\mathrm{CO}_{2}$ sequestration), water purification, disease control, biological pest control, pollination, recycling nutrients, providing fertile soils and prevention of erosion. There are a multitude of anthropocentric benefits of biodiversity in the areas of agriculture, science and medicine, industrial materials, ecological services, in leisure, and in cultural, aesthetic and intellectual value.

The Latin American and Caribbean region is a biodiversity superpower. It has one of the greatest endowments of natural capital in the world, which is a source of economic growth and has the potential of becoming the world leader in offering the services its ecosystems and biodiversity provide, and in return receive new benefits from this conservation and sustainable management. The region includes six of the world's most biodiverse countriesBrazil, Colombia, Ecuador, Mexico, Venezuela and Peru-as well as the single most biologically diverse area in the world, the Amazon. South America alone has more than $40 \%$ of the Earth's biodiversity, and more than one-quarter of its forests (Bovarnick et al., 2010; UNDP, 2010b). The Tropical Andes (Bolivia, Colombia, Ecuador, Perú and Venezuela) is the richest and most diverse region on Earth in terms of biodiversity -one of the major centres of world domestication, according to Vavilov-. It contains about a sixth of all plant life in less than one percent $(0.8 \%)$ of the world's land area, in an extension of $1,542,644 \mathrm{~km}^{2}$, from western Venezuela to northern Chile and Argentina, including large portions of Colombia, 
Ecuador, Peru, and Bolivia. Roughly bounded by the Tropic of Capricorn in the south and the end of the Andes range in Colombia and Venezuela in the north, the region follows the tropical portion of the Andes Mountains and several adjoining cordilleras (mountain ranges). The Member Countries of the Andean Community hold the first place in the world in diversity and endemism of vascular plants, birds, amphibians, and total vertebrates (excluding fish); and the sub-region is also the center of origin of important AndeanAmazon phytogenetic resources which supply approximately 35 percent of the world's agricultural food production and industrial production.

The Tropical Andes hotspot extends downward to an elevation of 1,000 meters in the west, down to 500 meters in the east, a cutoff between the forests of the Andean slopes and the Amazonian lowlands. Different types of vegetation correspond to gradients in altitude. Tropical wet and moist forests occur between 500 and 1,500 meters above sea level; cloud forests extend from 800 to 3,500 meters above sea level, including the montane cloud forests that cover more than $500,000 \mathrm{~km}^{2}$ in Peru and Bolivia and are among the richest and most diverse forests on Earth. At higher altitudes (3,000-4,800 meters), grassland and scrubland systems reach up to the snow line. These ecosystems include the páramo (moorland), a dense alpine vegetation growing on a thick mat of sponge-like, highly absorbent mosses and grasses in the cold, humid reaches of the northern Andes, and the drier puna, characterized by alpine bunchgrass species surrounded by herbs, grasses, sedges, lichens, mosses and ferns in the cold but dry southern Tropical Andes. In addition to these main ecosystems, there are also patches of dry forests, woodlands, cactus stands, thornscrub, and matorral (brush) found in this hotspot.

The Tropical Andes is home to an estimated 30,000-35,000 species of vascular plants, accounting for about 10 percent of the entire world's species and far exceeding the diversity of any other hotspot. It is also the world leader in plant endemism, with an estimated 50 percent (and perhaps 60 percent or more) of species found nowhere else on Earth. This means that nearly seven percent of the world's vascular plants are endemic to the 0.8 percent of the earth's land area represented by this hotspot. One of the more unique plant species is an Andean bromelilad that require 100 years to mature. This region also includes the largest variety of amphibians in the world, with 664 distinct species, of which near 450 species are listed as threatened on the 2004 IUCN Red List (www.biodiversityhotspots.org). Many rural and indigenous populations depend on biodiversity for their livelihoods, including fishing, nontimber forest products, and agriculture. The region's immense array of natural resources makes for a unique laboratory for products and processes that could incubate medical solutions for current and future generations (Bovarnick et al., 2010; UNDP, 2010a, 2010b).

\section{Use and conservation of biodiversity}

The use and exploitation of natural resources and specific biological diversity is one of the cornerstones for development for many countries with high biodiversity. This should be associated with the implementation of diversified markets that favor the quality and added values of the products obtained directly, as well as the services arising from their use. Plants and microorganisms are the most representative groups of biodiversity being used as source of industrial developments. The most important sector where plants are used for producing medicaments and drugs is the pharmaceutical industry. Plant species provide a great variety of products like food, medicines and raw materials. Some plant extracts are used in the manufacture of glue, soaps, cosmetics, dyes, lubricants and polishes among 
many other products. Plants also provide an important source of renewable energy and a new opportunity to take advance of the biotechnology potential (CBD, 2000).

The most direct and important use of biodiversity is as a source of food. Plant biodiversity is the basis of development and sustainability of agricultural production systems. A reduction in the genetic diversity of crops represents an increase in vulnerability to new pests and diseases. The economic value of the reservoir of genetic traits present in wild varieties and traditionally grown landraces is extremely important in improving crop performance (The Academies of Sciences, 2007). Although a large number of plant species are edible, only a small percentage is used intensively in the production of food with significant nutritional value. After 10,000 years of sedentary agriculture and the discovery of 50,000 varieties of edible plants, today only 15 crop species provide more than $80 \%$ of the food of the world. Rice, wheat and maize are the basic food for two thirds of the world population. Likewise only a few of the numerous animal species are used for food (FAO, 2004, 2011a). This situation has increased the vulnerability of agriculture and impoverished the human diet. As a result, many regional and local crops that have traditionally been important for feeding the poorest sectors of society are nowadays underutilized or neglected.

\subsection{Andean agricultural biodiversity}

The Andean region is one of the most important centers of crop origin in the world, containing a high diversity of domesticated crops and their wild relatives. The main nine Andean root and tuber crops (ARTC) are spread throughout South America from southeastern Venezuela to northwest Argentina, with the greatest diversity concentrated in Peru, Bolivia, and Ecuador.

The discovery of America brought about the biggest exchange of germplasm in history. Previously, only three species - one cultivated (sweet potato) and two spontaneous (bottle gourd and coconut) - were common to the agricultures of both the Old and the New World. After 1492, the exchange of cultivated species not only radically changed the diet of the majority of humankind but also led to commercial crops being developed in the tropics and a new world economic order being created. The relationship between human beings and cultivated plants affected everything from basic food and clothing requirements to the use of plants for ornamental purposes and leisure (FAO, 1994).

Ancestral Andean populations used natural resources for food and medicinal purposes. Among the most known are the root and tuber crops (ARTC), which are still of great economic and nutritional importance for Andean subsistence farmers. They can grow at high altitudes under extremely difficult conditions of drought, freezing temperatures, and UV exposure. Additionally they included fruits from the Yunga and Quechua zones in their diet. Some had very special flavours, such as the sachatomate, capulin, Peruvian pepino, various species of Cactaceae. passionfruit and mountain papayas as well as condiment, aromatic and medicinal species. The considerable plant genetic variability is explained by the profuse ecological diversity that characterizes the Andes. The presence of numerous progenitor and wild species related to the domesticated crop species represent an incalculable plant genetic resource, because they carry the genes for adaptation to a wide diversity of high Andean climatic conditions thus, their preservation is an urgent need.

Part of this huge agro-biodiversity includes:

- Andean tubers and roots: Potato (Solanum spp.), Oca (Oxalis tuberosa), Mashwa (Tropaeolum tuberosum), Bitter potatoes (Solanum $x$ jazepczukii), (Solanum $x$ curtilobum), Ullucu (Ullucus tuberosus), Maca (Lepidium meyenii), Arracacha (Arracacia xanthorrhiza), 
Mauka, chago (Mirabilis expanse), Leafcup (Polymnia sonchifolia), Yacon (Smallanthus sonchifolius)

- Andean grains and legumes: Canihua (Chenopodium pallidicaule), Quinoa (Chenopodium quince), Love-lies-bleeding (Amaranthus caudatus)

- Andean fruits: Pepino (Solanum muricatum), Tree tomato (Cyphomandra betacea), Mountain papaw (Carica pubescens)

\subsection{How traditional knowledge can be used to obtain new products}

The use of plants in healing processes in Colombia has an old history, where many learning, experiences and practices have been accumulated and inherited. During the XVI and XVII centuries when the Europeans learned of the healing procedures used by indigenous communities, a confrontation took place among the ways of healthcare, and how to understand the concepts of being healthy and the sickness. The use of plant therapies was the main base of the Greek and Arab medicine. During the middle ages these therapies were addressed into a scientific character expanding the pharmacopeia with plant species from Eastern and Western India and the discovery of America. The botanical development from XVI century where the plants were planted in botanical gardens to be studied and classified to learn of the potential from each species, allowed physicians to incorporate important knowledge of the medicinal use of plants.

Medicinal plants have the potential of being an important source of income for growers and transformers. Colombia as a mega-diverse country includes a vast ecosystem variety represented by tropical moist forests, savannah plain and alluvial forest. Many studies in Colombia undertaken by the Instituto de Investigación de Recursos Biológicos Alexander von Humboldt (Alexander von Humboldt Research Institute on Biological Resources), give evidence that the Country comprises nearly 50000 flora species of which at least 6000 have some kind of therapeutic use (Bernal et al., 2011). However, it is interesting that with this enormous potential of plants, the Vademecum prepared by INVIMA -Instituto Nacional de Vigilancia de Alimentos y Medicamentos -, registers only 95 species approved for medicinal use of which, only 11 are native plants.

In the Americas, only three Research Centers are working on alternative therapies in collaboration with the WHO Traditional Medicine activities in particular the Program for Collaborative Research in the Pharmaceutical Sciences at the University of Illinois at Chicago. They provide through their database of medicinal plants, NAPRALERT, free information to all nonprofit institutions in the Third World. One particular case is the experience of Peru where their studies have been focused on the phytochemistry of medicinal plants used by different ethnic communities. Some studies have evaluated the presence of alkaloids in plants commonly used, and the possible implications of their use. Additional studies have been conducted on pharmaceutical technology in order to contribute to solve health problems, and to expand intermediate pharmaceutical technology and pharmaceutical development.

An interesting experience in Peru is located in the highlands of Puno, where medicinal plants are among the most diverse and valuable in the region, have not only therapeutic but also nutritional benefits and are used in daily life (Jahuira \& Viviana, 2005). Many plants in this region are used for therapeutic purposes covered by traditional knowledge, habits, customs and ways of life of the Aymara-Quechua, and constitute the main response to the health problems of impoverished communities: respiratory disease, diseases of the oral cavity, dysentery and gastroenteritis, injuries and poisoning, diseases of the genito-urinary tract, skin diseases and subcutaneous tissue disease. 
The needs of private business, has stimulated increased use of medicinal plants seeking to find alternatives to some medical problems to prevent morbidity and mortality of highland populations, as well as a source of income for farmers. Indeed, several studies have demonstrated an important experience of the Andean communities in productive chains with ongoing efforts to establish integrated production processes, processing, use and consumption of medicinal plants to generate greater profits for the farmer in a sustainable way (Jahuira \& Viviana, 2005).

Also in Peru the Health Ministry has implemented health programs with the use of medicinal plants, whose services and holistic approach now consider the biological, mental and spiritual human being, besides the involvement of the family, experience performed by the formerINMETRO, now called the National Center for Intercultural Health (CENSI) whose objective requires the practice of traditional medicine power through scientific research programs. This led to joint actions with conventional medicine, based on the use of products from the region (Bernal et al 2011). The use of medicinal plants depends on the type of disease and treatment desired. Thus we find plants that can be taken alone or combined with other plants. The plants most used are: Amaccari (Boconia frutescens), Sano sano (Cyathea spp.), Vino vino (Tradescantia zanonia), Cascarilla (Cinchona calisaya), Lacre rojo (Vismia macrophylla), Nogal (Junglans neotropica), Ayapira (Picramnia sellowii subsp. spruceana), Suli suli (Cestrum sp.), Pajuaito (Erechtites hieraciifolius), Ortiga negra (Urera laciniata), Sangre de grado (Croton lechleri), among others (Corporazione Italiana; De Vida, 2008; Damiano et al., 2011)).

In Colombia, the development of knowledge on medicinal plants has been slow and the documented experiences are limited to certain regions and ethnic groups. However, some cases deserve to be highlighted, as will be shown. In recent years, studies evaluating the uses of plants (both timber and non timber) in the Amazon Piedmont have been conducted by the SINCHI scientific research institute, for different communities comparing similar uses according to ethnicity. Results show that in most cases, treatments remain within their communities (Bernal et al., 2011). Previous studies have found that many of the species to which some communities give more importance, are related to the construction and sawmilling activities rather than to medicine or food, which suggests that, depending on the interests of the community these should be evaluated.

A number of functional properties, suggested by ethnomedicine against a wide range of dysfunctions and pathologies (e.g. gastric ulcers, diarrhea, microbial and viral infectious wounds, insect bites neurogenic inflammations, arthritis), have also been also corroborated and have led to a number of commercial products (Gupta, 2008).

One of the initiatives in medicinal plants promoted by the Colombian Government conducted a national survey of medicinal and aromatic plants as a useful tool to understand the situation in an exploratory way. The survey permitted reaching the main actors who participate in this chain of production and learn about their business and legal issues, as well as the market expectations of the use of medicinal plants in Colombia. It also permitted identifying other medicinal and aromatic plants sold in Colombia. One of the major problems was the refusal by several laboratories to be part of the survey. A high percentage did not respond to it, probably due to their position on commercial and regulatory conditions -under which the sector develops-.

Examples of medicinal plants used in phytotherapies in different Andean countries

- Bolivia: Cedrela fissilis belongs to the Meliaceae family. It is a plant grown in tropical America from Mexico to Argentina and it is representative of Bolivia. The ethanol 
extract of the dried plant has been evaluated for its cytotoxicity and antitumoral activity against various cell lines presenting a weak antitumoral activity against P338 leukemia. Toxic effects have been identified at doses of $1800 \mathrm{mg} / \mathrm{kg}$ in mice (Suffness et al, 1988).

- Colombia: Ilex guayusa belongs to the Aquifoliaceae family. It is a plant that grows in southern Colombia and along the border with Ecuador at altitudes between 200 and $2000 \mathrm{~m}$ in tropical rainforests and secondary vegetation (Correa and Bernal 1990). The Indian communities have used the leaves as stimulant for nerve and muscle. Compounds act as digestive, emetic and expectorant, and in some cases have shown effects against diabetes.

- Another important plant species in Colombia is Croton lechleri Müll. Arg. (sin. Croton draconoides Müll. Arg., Euphorbiaceae). It is a small-sized Amazonian tree growing on the eastern Andean slopes of Peru, Colombia, Bolivia and Ecuador, commonly known as sangre de drago, sangregado, palo de grado, pocure, racurana, sangre de dragòn, sangre de grado or named with the Quechua terms of arleiia and lan huiqui (Gupta, 2008). A recent study on Croton lechleri (Damiano, et al 2011), examined for the first time the essential oil obtained by steam distillation of fresh stem bark from Amazonian Ecuador Croton lechleri adult plants. The results showed sesquiterpene prevalence and clarified the structure of the major compounds. Antioxidant and antibacterial assays were also performed employing (HP) TLC-bioautography strategy to detect the fraction(s) that would best determine the biological activities. Some fractions showed having antioxidant and antibacterial activity, while one of the fractions ( $R F=0.7)$ almost exclusively characterized by sesquicineole, displayed only antibacterial properties. The efficacy of the essential oil was weak in relation to positive controls of commercial thyme essential oil and BHA, but similar to that expressed by other Croton spp. essential oil as reported in related literature.

- Perú: Tara is a plant produced in several areas of Peru between 1000 and 2900 masl.. The sheath is separated from the seed and is an excellent export product as feedstock for the production of tannic acid used in the fur industry, pharmaceutical paints and other chemical products. From Tara seeds, using thermal-mechanical process a food grade gum from the endosperm can be obtained, constituting an alternative to traditional rubber global food industry, paints and varnishes, among others. This gum was approved by Resolution on September 26, 1996 (No. ECC: E-417) by the European Community, to be used as a thickener and stabilizer in food for human consumption. (de la Cruz Lapa, 2004).

- Venezuela: Averroe bilimbi, species belonging to the Oxalidaceae family is a small tree native to India and cultivated in Venezuela. This plant is used to cure abscesses and inflammation. Extracts of this plant are used against diarrheal diseases. In preclinical studies it has been shown that the extract of the fruits of Averroe bilimbi has mutagenic activity when injected into mice intraperitoneally at a dose of $50 \mathrm{ml} / \mathrm{kg}$. Studies have shown its effect on amenorrhea in women with menstrual delay between 10 and 111 days $80 \%$ of the patients recovered function. (Gupta, 2008).

- Ecuador: Myroxilom balsamum is a Leguminosae-Papilionoidae plant family called the balsam tree, widely grown in Ecuador. Ethnobotanical knowledge reports that the balsam tree produces a yellow balm that solidifies to crystal pieces. The drug has expectorant and antiseptic functions. (Gupta, 2008). In medicine, the black salve is used to treat ulcers. Pharmacopoeia in Mexico recommends the tincture of the fruits as 
antispasmodic and stimulant especially in cases of eclampsia. It was found that the ethanol extract at a concentration of 2000 ppm has antibacterial activity against several species of Staphylococcus and antifungal activity against certain species of Trichophytum. The active ingredients of the balsam are benzoic acid and cinnamic acid, benzyl benzoate, nerodiol and resins (Walberg \& Enzel, 1971).

- Cuba: Studies conducted in Manilkara zapota plants, belonging to the Sapotaceae family have shown that their seeds are compounds that are used in digestive disorders, colitis, diarrhea and parasitism. Likewise, these compounds are effective for treating colds, kidney pains and hair loss. There are also reports of use of the leaves in treatments for skin conditions (Roig, 1988).

- Additional plants of interest include:

- $\quad$ Leaves from the plant species belonging to the genus Ligustrum are used as herbal medicine in Europe, China, and Japan. The antioxidant properties of five Ligustrum species from Taiwan were compared by using in vitro antioxidant methods such as DPPH radical scavenging, TEAC, and FRAP assays. Cell-based antioxidant methods were used, including Fe2+/ascorbate-induced lipid peroxidation on brain homogenate and AAPH-induced erythrocyte haemolysis. The amounts of major phenolic compounds from the Ligustrum species, including phenylpropanoids, flavonoids, and iridoids, were determined by spectrophotometric methods. The results showed that all Ligustrum species exhibited antioxidant, radical-scavenging, anti-haemolytic, and lipid peroxidation-inhibiting activities at different magnitudes of potency. Among all Ligustrum species from Taiwan, Ligustrum morrisonense is presented as a potential source of natural antioxidants (Chi-Rei et al., 2011).

- Centella asiatica is a perennial herb with high utility in traditional medicines, herbal drugs and cosmeceutics. (Munduvelil, T., 2010). Medicinal properties of C. asiatica have been ascribed to its bioactive pentacyclic triterpenoid derivatives such as asiaticoside, madecassoside, asiatic acid and madecassic acid (Inamdar et al., 1996). Asiaticoside has been identified as an active compound in C. asiatica associated with its wound healing properties (Shukla et al., 1999). Wound healing activity of asiaticoside is a result of stimulation of collagen and glycosaminoglycan synthesis (Cheng et al., 2004). It is also found to have activity against herpes simplex viruses 1 and 2, mycobacterium tuberculosis and as a neuroprotectant (Lu et al., 2004).

\subsection{Conservation of biodiversity and genetic resources}

Meeting the food needs of the world's growing population while reducing poverty and protecting the environment is a major global challenge. It is essential to take environmental concerns into account in order to develop technological solutions that are sustainable in the long run. According to the UN Millennium Project (2005), meeting these demands will require agricultural productivity increases and product diversification to improve the livelihoods of the poor, protect the environment, and ensure broad-based economic growth. Plant genome sciences, and plant biology as a whole, are vital enterprises that can contribute significantly to human health, agriculture, energy security, and environmental stewardship (The Academies of Sciences, 2007). Biodiversity and agriculture are strongly interrelated because while biodiversity is critical for agriculture, agriculture can also contribute to conservation and sustainable use of biodiversity. Indeed, sustainable agriculture both promotes and is enhanced by biodiversity. Maintenance of this biodiversity is essential for 
the sustainable production of food and other agricultural products and the benefits these provide to humanity, including food security, nutrition and livelihood (Hodson, 2009). Biodiversity and ecosystem services conservation, and sustainable management are essential to the future of the Andean region and its long-term competitiveness. Bioprospecting, the emerging field of biomimicry and biotrade depend heavily on diverse, sustainable and healthy ecosystems. Investment in knowledge, research and technology development is necessary to be at the forefront of natural resource-based technologies, products and markets (UNDP, 2010a, 2010b).

Biodiversity is crucial as a strategic resource, with an essential function in the cycles of the bioelements, in climate regulation, in maintaining the viability of agriculture, fishing, and other activities associated with food security. Thus, the conservation of the enormous diversity in the Andean Region is imperative for preserving life multiplicity and maintaining a natural balance among species. The Andean natural resources continue to be exploited in an unsustainable way and the availability of these resources for use in the development of the region is threatened by processes of environmental degradation, such as deforestation, erosion, sedimentation, contamination, and rapid urbanization, among others.

Several anthropological factors are known as directly and indirectly affecting the state of conservation of ecosystems and biodiversity. Among them are the high levels of poverty, insufficient environmental education, increased population and urban development, extension of the agricultural/livestock frontier, forest extraction, opening of new roads, the slash and burn system, overgrazing, burning of pasturelands, over-exploitation of biological resources, oil extraction, gold mining, trade, tourism, introduction of alien species, and pollution. One frequently mentioned natural cause of the alteration of ecosystems is that of extreme climatic phenomena. Additionally, invasive alien species are one of the principal threats to worldwide biological diversity, and could result in serious deterioration of the megadiversity of the Andean sub-region (CAN, 2002, FAO, 2011a, 2011b). In the cloud forests, agriculture, deforestation, dams, and road building are the most significant threats. At higher altitudes, seasonal burning, grazing, agriculture, mining, and fuelwood collection have degraded the grasslands and scrublands of the puna and páramos. One of the most important and directly measurable land degradation impacts are associated with extensive cultivation of opium poppy, which has led to the clearing of thousands of hectares of montane forests and the spread of chemical herbicides through rivers and streams that pose additional threats to plant and animal species, especially amphibians. Activities associated with this trade often make it difficult to safely sustain conservation activities in the area (Hodson, 2009). Coca, once grown for local consumption in the Andes, is now produced for external markets, often in areas with armed groups -that generate instability and often serve to secure land for unscrupulous investors-. Internationally financed eradication campaigns force traffickers and growers to constantly relocate, making drug-related activities a principal cause of forest loss. The range of environmental impacts from illicit crops, trafficking, and violence is broad, and must be studied (Fjeldsa et al, 2005).

The growing concern on genetic erosion has led to the establishment of germplasm conservation programs worldwide. Approaches for biodiversity -germplasm- conservation include: Collection, identification and documentation of genetic resources, consideration of the impacts of traditional farming, cropping and agroforestry systems and the use conventional landraces and cultivars of domesticated plants and wild related species. The 
two major strategies for conservation of genetic resources are: a.- "in situ" conservation, which allows continued evolution and adaptation of a species in response to the environment; -though more dynamic, it is exposed to habitat destruction by natural calamities and/or human interference-, and b.- "ex situ" conservation, which can be used to ensure easy and ready accessibility of reproductive material. Effective conservation strategies often incorporate elements of both. For example, ex situ collections can be used for in situ population enhancement, or even to reintroduce rare/extinct species in the wild (Hodson, 2009).

To comply with the compromises on the Convention on Biological Diversity (CBD), the five Member States of the Andean Community (Bolivia, Colombia, Ecuador, Peru, and Venezuela) approved by Decision 523 the Regional Biodiversity Strategy for the Tropical Andean States. The Strategy (signed in July, 2002) is the result of a participative process of the Andean Committee of Environmental Authorities (CAAAM), in cooperation with representatives from different sectors related to the conservation and sustainable use of biodiversity, including public sector, native, Afro-American and local communities, along with the industrial and academic sectors, civil society, consumers and international organizations. It establishes approaches for the cooperative conservation and sustainable use of biodiversity around six main general objectives: 1) Conservation and sustainable use of ecosystems, species and genetic resources in situ and complementary actions ex situ; 2) Equitable sharing of benefits, based on a correct economic valuation of the biodiversity components; 3) Protection and enhancement of knowledge, innovations, and practices of the indigenous, Afro-American, and local communities based on recognizing their individual, community, and group rights; 4) Development of scientific knowledge, innovations and technologies for the conservation and the sustainable use of biodiversity, while preventing and minimizing risks to the environment and human health; 5) Inclusion of the conservation and sustainable use of biodiversity in sectoral policies and development projects with subregional impact; and, 6) Development of the capability for international negotiation regarding the conservation and sustainable use of biodiversity in the Andean Community (CAN, 2002).

One of the main objectives of the Global Treaty on Plant Genetic Resources for Food and Agriculture is to save and share crop diversity. As of March 2011, the gene pool created under it had reached 1.5 million samples of the world's 64 most important food crops, where one-sixth of the signatories have made their crop collections available under the Treaty. Between 600 and 800 samples are exchanged each day through the Treaty's Standard Materials Transfer Agreement (SMTA), which has been helpful in overcoming legal obstacles that in the past have prevented breeders and researchers from gaining access to critically needed crop-breeding materials. The global fund of the International Treaty is currently supporting projects all around the world to help farmers in 11 developing countries to conserve crop diversity and to adapt to weather extremes and other threats to food security. For example, in Peru, the fund is helping to maintain biodiversity in the 15,000-hectare "Potato Park", where local and indigenous farmers are reintroducing thousands of heirloom potato varieties to adapt them to rising temperatures. Scientists predict that diseases and other threats aggravated by climate change could decrease potato yields by one third in coming decades.

Information supplied by the countries of the Andean sub-region reveals a significant number of germplasm banks that contain genetic resources of great importance for agriculture, socioeconomic aspects, and food security. The Andean Community registers 88 
active banks (preserving tuber and root crops, cereals, vegetables, fruit trees, forest trees, leguminous crops, forage species, industrial plants and ornamental plants), of which $50 \%$ are managed by public institutions. Additionally and in relation to germplasm banks, the two international CGIAR centers of the Andean subregion (International Potato Center, and International Center for Tropical Agriculture) operate within the multilateral framework established by the FAO International Commitment.

Despite the high level of threat in the Tropical Andes, a network of protected areas today conserves some of the most important remaining intact ecosystems in the hotspot. Protected areas cover some 16 percent of the original extent of vegetation in the region, although only about eight percent of the hotspot is protected in reserves or parks under IUCN categories I to IV. However, even these parks are not inviolate, and without adequate enforcement and monitoring, they can be damaged by settlement, poaching, and illegal logging. Because research has shown that small parks may not adequately protect biodiversity in the long term, conservation efforts in the Tropical Andes have focused on the need to add to and connect this network of protected areas. By connecting existing parks through corridors of protected areas and biodiversity-friendly, sustainable development projects, ecological processes like migration, dispersal, and gene flow among populations are enhanced. For example, Conservation International has begun the implementation of the Cóndor-Kutukú Conservation Corridor,including the following areas in Ecuador: Podocarpus National Park, Sangay National Park, Condor National Park, Cordillera de Kutukú and Cordillera del Cóndor. In Peru, the Corridor includes the Santiago-Comaina Reserved Zone, Tabaconas-Namballe National Sanctuary and Cordillera Azul National Park (Fjeldsa et al, 2005).

Colombia has a National Environmental System coordinated by the Ministry of Environment that involves 33 Regional Autonomous Corporations, the National Park Service and five research institutes promoting terrestrial and marine biodiversity conservation research. The National System of Protected Areas (SINAP); indigenous reserves and Afro-Colombian collective territories extend over $37 \%$ of Colombia's terrestrial land and include representative samples of $70 \%$ of the country's natural ecosystems providing important safeguard to the country's natural heritage. If forest reserves and other conservation categories are added, an approximate $43 \%$ of Colombian territory is under some sort of conservation scheme (UNDP, 2010a).

As mentioned previously, genetic resources are the raw material for agricultural development and continued survival of natural populations. Therefore their sustainable use is crucial for global food security and economic well-being. An additional and valuable tool for the conservation and sustainable utilization of biodiversity is biotechnology. Biotechnologies are increasingly being applied to enhance genetic resources for food and agriculture GRFA (FAO, 2011a). Biotechnology applications can provide comparative advantages over, or can increase the effectiveness of, traditional technologies for the characterization, conservation and utilization of GRFA. Biotechnology applications for characterization include molecular markers and the so-called "omic" technologies. The two FAO reports related to the state of food and agriculture (2003-2004 and 2010-2011) deliver an overview of the current status of biotechnology applications applied to the characterization, conservation and utilization of GRFA, as well as the comparative advantages that biotechnologies can provide over conventional technologies (FAO, 2011a, 2011b, 2004). Correspondingly, the Commission on Genetic Resources for Food and Agriculture observing the increased use of biotechnology in the conservation and sustainable use of 
GRFA over the past 15 years, has been considering the application and integration of biotechnologies in biodiversity issues "maximizing the positive effects and minimizing the negative effects of biotechnology".

In fact, both the Global Plan of Action for the Conservation and Sustainable Utilization of Plant Genetic Resources for Food and Agriculture and the Global Plan of Action for Animal Genetic Resources identify a direct or indirect role for agricultural biotechnologies in some of their priority areas. Characterization is a prerequisite for identifying and prioritizing the genetic resources to be conserved and is fundamental for optimizing appropriate allocation when resources are limited. Characterization also links conservation and utilization as it allows identifying unique and valuable traits of conserved genetic resources, both in situ and $e x$ situ, for incorporation into breeding programmes (FAO, 2011a).

\section{Regulatory frame}

During the last three decades there has been worldwide increased interest regarding environmental and natural resources issues. While in the 20th century concerns were raised in relation to the impacts of human activities, dangers of environmental degradation and possible effects on climate change, desertification and pollution, the 21st century is bringing more awareness of the real value of biodiversity and the ecosystems in which they live to provide us food, water, human health, and climatic stability (UNDP, 2010b). There are several International and Regional treaties and agreements related to biodiversity, and each country has its individual regulations. The main regulatory broad frame is the Convention on Biological Diversity (CBD), adopted at the 1992 Earth Summit in Rio de Janeiro, where world leaders agreed on a comprehensive strategy for sustainable development - "meeting our needs while ensuring that we leave a healthy and viable world for future generations"-. The Convention has 193 Parties and three main goals: conservation of biological diversity, sustainable use of its components, and fair and equitable sharing of the benefits from the use of genetic resources (www.cbd.int/).

The CBD enhanced the world's commitment in relation to environmental management and biodiversity conservation -sustainability-, and is one of the most relevant subjects of international relations and policies, as well as National sovereignties towards control over biological resources. The potential value of genetic resources (especially in developing countries with high biodiversity) has generated the development of mechanisms to regulate and control the collection, trade and research related with biological resources, while developed countries are trying to extend patent laws, intellectual property rights, and biotechnology on the use of components of biological resources (Grajal, 1999). The Latin American and Caribbean nations represent the most biologically diverse region on Earth. South America alone is home to almost half of the planetary biodiversity, and more than a quarter of its forests. The Americas as a whole possess nearly 122 million hectares of fertile land, 93 million hectares of grassland, more than 132 million hectares of forest, and $27 \%$ of the world's available fresh water (UNDP, 2010b).

The fair and equitable sharing of benefits arising from the use of genetic resources (ABS) is the third objective of the Convention and several articles of the Convention set out terms and conditions for access to genetic resources and benefit-sharing. Since 2004, Parties to the Convention have been negotiating an instrument to effectively implement the ABS provisions of the Convention. At its tenth meeting, in Nagoya, Japan, the Conference of the Parties adopted the Nagoya Protocol on Access to Genetic Resources and the Fair and 
Equitable Sharing of Benefits Arising from their utilization. In Decision $X / 1$, Parties requested that the Secretariat provide technical assistance to developing country Parties seeking to support the early entry into force and implementation of the Nagoya Protocol. In light of this request, a number of capacity building and awareness-raising activities on the Nagoya Protocol are planned for the next two years.

An important consideration regarding regulations and agreements related with biodiversity, natural resources, sovereignty and local communities is that this normative frame is intended for the protection of the rights and to improve welfare, food security health and safety of the society, especially the most needed in developing countries, which depending on the interpretation given to the regulation, might result exactly in the opposite.

\subsection{International agreements}

The principal international agreements and treaties related to biodiversity and trade are briefly described:

Convention on Biological Diversity (CBD) (www.cbd.int/)

Entered into force in 1993 - Legally binding for countries that have ratified (193 as of April 2011)

Covers all biodiversity; provides general principles for the conservation of biological diversity, the sustainable use of its components, and the fair and equitable sharing of the benefits from the use of genetic resources.

International Treaty on Plant Genetic Resources for Food and Agriculture ITPGRFA (http://www.planttreaty.org/)

Entered into force on 29 June 2004 - Legally binding for countries that have ratified (127 as of April 2011)

Covers all PGRFA and addresses diverse topics, including conservation, use, international cooperation, technical assistance and farmers' rights. No country is self-sufficient in plant genetic resources; all depend on genetic diversity in crops from other countries and regions thus, international cooperation and open exchange of genetic resources are essential for food security. The objectives of the Treaty are the conservation and sustainable use of Plant Genetic Resources for Food and Agriculture and the fair and equitable sharing of the benefits arising from their use, in harmony with the Convention on Biological Diversity, for sustainable agriculture and food security; establishes a multilateral system for select crops (approx. 35 crops/crop complexes plus certain forages); sets rules for access and benefit sharing for these materials, both ex situ and in situ. The ITPGRFA creates the Multilateral System of Access and Benefit-sharing, which provides for facilitated access to plant genetic resources for food and agriculture (ITPGRFA Article 12.3.a), which includes 35 crops and 29 forage genera (Annex 1 of the ITPGRFA). At its First Session, in June 2006, the Governing Body of the ITPGRFA adopted a Standard Material Transfer Agreement (SMTA), which sets out the legal conditions that apply to both providers and recipients of plant genetic resources for food and agriculture (PGRFA) in the Multilateral System.

International Plant Protection Convention IPPC (https:/ /www.ippc.int/)

Established in 1952. Revised text entered into force in 2005 - Legally binding for countries that have ratified (177 as of April 2011)

International treaty seeking to secure coordinated, effective action to prevent and to control the introduction and spread of pests of plants and plant products protecting cultivated and wild plants. Addresses phytosanitary issues with the transfer of plants and animals. 
WTO Agreement on the Application of Sanitary and Phytosanitary Measures (SPS Agreement) (http:/ / www.wto.org/)

Entered into force in 1 January 1995

The WTO-SPS Agreement recognizes the IPPC as the relevant international standard setting organization for the elaboration of international standards to help ensure that phytosanitary measures are not used as unjustified barriers to trade. The health aspect of the SPS Agreement basically means that WTO members can protect human, animal or plant life or health by applying measures to manage the risks associated with imports. The measures usually take the form of quarantine or food safety requirements.

Agreement on Trade-Related Aspects of Intellectual Property Rights - WTO-TRIPS (www.wto.org/)

Entered into force in January 1995 - Legally binding for members that have ratified it (153 as of April 2010)

Member States

The Multilateral Trade Agreement embodies provisions on Trade Related Intellectual Property (TRIPS). As a result, many countries are now developing and enacting intellectual property rights legislation, including plant variety protection (SGRP, 2010). It introduced intellectual property legislation into the multilateral trading system. Member states must comply with minimum standards of protection of intellectual property and ensure protection of microorganisms, non-biological and microbiological processes and plant varieties that meet protection criteria. The TRIPS Agreement has an important principle: intellectual property protection should contribute to technical innovation and the transfer of technology. Both producers and users should benefit, and economic and social welfare should be enhanced, the agreement says.

UPOV 1961, 1972, 1978, 1991 - Plant Breeders' Rights (http:/ /www.upov.int/)

Legally binding for ratifying countries (68 as of April 2010)

Through a succession of international laws, UPOV aims to harmonize national laws for protecting plant varieties. The objective is to provide and promote an effective system of plant variety protection, with the aim of encouraging the development of new varieties of plants, for the benefit of society. The UPOV Convention provides a sui generis form of intellectual property protection which has been specifically adapted for the process of plant breeding and has been developed with the aim of encouraging breeders to develop new varieties of plants.

Agreements entered into by the governing body of the Treaty on Plant Genetic Resources for Food and Agriculture ITPGRFA and the CGIAR centres and other international institutions under Article 15 of the Treaty

The eleven CGIAR Centres hosting international crop and forage collections have signed agreements with the Governing Body of the ITPGRFA (in 2006), placing those collections under the overarching international framework of the ITPGRFA.

11 CGIAR centres (those having ex situ collections) have signed binding agreements with the Governing Body, (place the ex situ collections held in trust by the Centres and other international institutions within the purview of the Treaty)

The System-wide Genetic Resources Programme SGRP (SGRP, 2010) (http://www.sgrp.cgiar.org/) of the Consultative Group on International Agricultural Research (CGIAR) unites the CGIAR's independent agricultural research Centres in a common effort to sustain biodiversity for current and future generations. The diversity embodied in plant, animal, forest and aquatic genetic resources supplies the building blocks 
for sustainable agriculture to fight poverty, bring health and food security, and protect the environment. The SGRP is the culmination of a long-standing collaborative partnership among CGIAR Centre scientists and technicians involving sharing of know-how and joint action to address common research problems. The focus of the collaboration has always been the CGIAR Centre genebanks' plant genetic resources collections and the challenges surrounding their management. The Booklet of CGIAR Centre Policy Instruments, Guidelines and Statements on Genetic Resources, Biotechnology and Intellectual Property Rights (Version III, August 2010), was updated to include policy instruments and guidelines related to the management of PGRFA under the framework of the Treaty.

FAO/IPGRI Genebank Standards (ftp://ftp.fao.org/docrep/fao/meeting/015/aj680e.pdf) Recommended by FAO and IPGRI -currently Bioversity International- to be used as the reference in national, regional and international genebanks. Endorsed in 1993 by FAO Commission on Plant Genetic Resources -not legally binding-, sets out recommended gene bank storage standards for seeds of orthodox species only

FAO Code of Conduct for Plant Germplasm Collecting and Transfer

(www.planttreaty.org/smta_en.htm)

Adopted by FAO Conference in 1993, not legally binding

Deals with the etiquette of collecting and transfer of PGRFA. Both the Treaty and the CBD have provisions that add to, or modify the guidance provided by the Code and have provisions on collectors' permits, responsibilities of collectors, sponsors, curators and users, as well as on reporting, monitoring and evaluating observance of the Code

CGIAR policies/ instruments (http:/ / www.sgrp.cgiar.org/?q=node/1053)

Apply only to the CGIAR. Some of the policies and instruments are related to the Governing Body-CGIAR agreements and specify actions that must be taken by centres to meet these contractual obligations.

Centres' Guide to the Implementation of the Standard Material Transfer Agreement (SMTA) and includes: Guidelines for germplasm acquisition; Model MTA for use with nonfood/feed crops; Guidelines for acquisition and transfer of germplasm: micro-organism, animal and aquatic and marine; Ethical principles related to genetic resources; Guiding principles on Centres' Intellectual Assets; Principles involving centre interaction with the private sector; Position statements on biotechnology, the FAO-CGIAR agreements, 'genetic use restriction technologies' and the need to resolve certain issues concerning IPRs and genetic resources.

The Nagoya Protocol on Access to Genetic Resources and the Fair and Equitable Sharing of Benefits Arising from their Utilization to the Convention on Biological Diversity (http://www.cbd.int/abs/)

Adopted by the Conference of the Parties to the Convention on Biological Diversity at its tenth meeting in October 2010 in Nagoya, Japan. It will be open for signature by Parties to the CBD from 2 February 2011 until 1 February 2012 at the United Nations Headquarters in New York. It is an international agreement which aims at sharing the benefits arising from the utilization of genetic resources in a fair and equitable way, including by appropriate access to genetic resources and by appropriate transfer of relevant technologies, taking into account all rights over those resources and to technologies, and by appropriate funding, thereby contributing to the conservation of biological diversity and the sustainable use of its components. It deals with "access and benefit sharing" with countries or local communities when inventors use genetic materials and any associated traditional knowledge. It builds on the long-established principles of the CBD itself. 


\subsection{Subregional Agreements (Community of Andean Nations CAN) (http://www.comunidadandina.org/ingles/treaties.htm)}

Because Andean countries as a group probably hold the largest portion of biological diversity in the world in absolute numbers, endemic and restricted range species, these countries have been among the first in the world to define a legal regulatory framework to control the access to genetic resources, and agreements to comply with the Convention on Biological Diversity. International trade in the products of biological diversity is subject to a series of regulations and trade agreements, where attention has focused on how to deal with the problem of tariff and non-tariff barriers that affect trade. The effect that the opening-up of the economies of the CAN member countries has on the patterns of use of biodiversity needs to be studied in depth for specific biological resources. The Andean Environmental Agenda for 2006-2010 provides for the formulation and organization of the Andean Strategy on Climate Change - EACC and its corresponding Action Plan. This Agenda contains both short- and medium-term subregional actions that add value to national efforts and help strengthen the capacities of the Member Countries with regard to environmental and sustainable development issues.

To date, the most relevant agreements in Andean Community related to biodiversity and trade are:

Common Regime on Access to Genetic Resources - Decision 391: Aims to regulate access to the genetic resources of the Member Countries and their by-products, taking into account that the Member Countries have sovereignty over the use and development of their resources and possess a sizeable biological and genetic heritage that should be preserved and developed on a sustainable basis. Decision 391 defines the basis for a common regime for access to genetic resources by the Andean Pact countries. This resolution imposes new cumbersome controls upon access of genetic resources. If implemented in letter and spirit, Decision 391 will impose disincentives on biodiversity research, and therefore will impair growth in the knowledge base of Andean biodiversity at a time when these countries need more information to better manage their biological resources (Grajal, 1999).

Regional Biodiversity Strategy for the Tropical Andean Countries - Decision 523: It is one of the first strategies of a regional nature adopted by a group of countries signatories of the Convention on Biological Diversity, and it is a specific contribution to meeting the goals of the Convention. At the same time, it is a valuable instrument for enhancing the Andean peoples' own perception of the importance of their rich natural heritage, and a fundamental one for ensuring the sustainability of the Amazon Basin as a whole. It is also a tool of great significance for constructing new kinds of relationships among countries, regions, and continents. It aims to set bases for a community policy with other countries on the subject of biodiversity, in view of the challenges the subregion confronts in the process of negotiating the Free Trade Area of the Americas ( FTAA), in the World Trade Organization (WTO), and in other bilateral and multilateral negotiation processes, including international environmental conventions, in particular the Convention on Biological Diversity and the International Treaty on Plant Genetic Resources for Food and Agriculture.

Common Provisions on the Protection of the Rights of Breeders of New Plant Varieties Decision 345: Its purpose is: (a) to recognize and ensure the protection of the rights of breeders of new plant varieties by the grant of breeders' certificates; (b) to promote research activities in the Andean area; (c) to promote technology transfer activities within and outside the subregion. The scope of this Decision encompasses all botanical genera and 
species insofar as the growth, possession or use thereof are not prohibited for reasons of human, animal or plant health.

Common Intellectual Property Regime - Decision 486: Replaces Decision 344. The objective is the protection of intellectual property considering the agreements of the World Trade Organization -including the Agreement on Trade-Related Aspects of Intellectual Property Rights (TRIPS)-, and the Paris Convention for the Protection of Industrial Property.

Consultative Council of the Andean Community Indigenous Peoples - Decision 674: The Council acts as a consultative body within the framework of the Andean Integration System to promote the active participation of indigenous peoples in economic, social, cultural and political matters concerning subregional integration.

Integral and Sustainable Alternative Development Andean Strategy - Decision 614: With the objective of contribute to the reduction of poverty and to achieve social cohesion in the Member Countries, in the target areas defined, and to establish policy guidelines, conceptual focusing and goals and indicators, for alternative development actions and projects, with a comprehensive and sustainable approach.

Andean Committee of Environmental Authorities (CAAAM) Decision 435: Establishes the "Comité Andino de Autoridades Ambientales" integrated by environmental authorities of the Member Countries as an advisor body in environmental issues.

\section{Indigenous communities, traditional knowledge and biodiversity}

It is common to find a linear view of biodiversity as an input for research and foresight that eventually enters into the value chain of the economic system. The mindset of anthropological positions is far from being instrumental, understanding that biodiversity is an integral part of indigenous peoples and this is indispensable from their cultural environment, dignity and survival (Brush, 1993; Dove, 2006).

Knowledge of how to interact with tropical ecosystems is not merely confined to crops, but includes environmental issues such as recovery from floods, forest regeneration, along with management of species migration, soil dynamics and water management among others (Naveh, 1998). Biodiversity in ancient knowledge has value beyond the use of plants, animals and other natural resources for medicine, food and industry. Biodiversity also determines and is determined by certain traditional practices of cultivation and management of soil, seeds and animals, forms of natural resource management, rituals and ceremonies as well as a set of rules and metaphors about the use and conservation of biodiversity.

Over the years Indigenous peoples have been advocated to sustain a struggle for the conservation and use of biodiversity, especially on issues such as food sovereignty. Also the Indians have had to negotiate their rights over traditional knowledge and genetic resources. Finally, the Indian communities have made progress in advocacy through the creation of organizations that have expanded the possibilities to govern over their environment, resources and knowledge.

\subsection{Biodiversity and food sovereignty}

Policies to combat poverty have often prioritized food security, which consist in ensuring food obtained via the mass production of few and low cost crops. Instead, food sovereignty is designed to guarantee the people the means to grow their own traditional food (Montagut \& Dogliotti, 2006). 
The biological diversity of crops has been focused on a struggle between the imposition of varieties and seeds, and the right of people to feed themselves with their own crops. For example, during the period of expansion of the Inca empires' (1400-1500), the leaders stepped up the production of maize and potato because of their ease of extensive cultivation and storage. Throughout the area known as Puacartambo (between Ecuador and Peru), the Incas imposed on the families the widespread cultivation of maize and potato. With the Spanish conquest new crops such as barley and wheat were added, and introduced additional pressures that threatened the food sovereignty of the indigenous American people. Indigenous communities created new organizational forms, which divided the land and labor for the production of traditional varieties (Zimmerer, 1999; Zimmerer, 1993). Crops are culturally rooted (in fact the word culture is derived from crop), and certain plants have some fundamental properties for ceremonies and rituals.

With the birth of the republics in Latin America, indigenous Andean communities increased their chances of influencing the public sphere, interacting with the new state to guarantee their rights, but things did not change much. The Indians began to organize protest, as shown in the case of Cochabamba, Bolivia in 1881, where the natives of the country gathered to defend the right to sow their own food and require support to extend their traditional crops. Currently, the planting of local and traditional varieties in the Andean region is socially divided. On the one hand, the rich classes have grown varieties of exclusive consumption and poor farmers grow varieties for subsistence (Zimmerer, 1993).

Contrary to what is commonly believed, Zimmerer's work shows that Inca crops did not use and extend biodiversity in agriculture. Households and ancient indigenous organizations of families were the social units that preserved over the years the biodiversity and ancestral knowledge. The resistance of indigenous peoples to lose their traditions and lifestyles, along with their identity and their right to food sovereignty, had allowed the preservation of traditional knowledge (Zimmerer, 1999). Likewise, the establishment and extension of traditional crops is a form of defense against the domination in the Andean countries and a way of sustaining its food security (Dove, 2006). However, in recent decades the problem of food security has been neglected by the negotiation of ownership of traditional knowledge and biodiversity.

\subsection{The negotiation of traditional knowledge and biodiversity}

Through the years, indigenous people have been at a disadvantage when negotiating with different researchers and corporations that have been seeking to access their knowledge and biodiversity. Bioprospecting, dating in modern science from the nineteenth century botanical expeditions, has been a topic of concern for indigenous people in recent times. Latin America has many cases in which indigenous communities receive little or nothing in return for their knowledge and genetic resources, due to the institutional gap on issues such as the property of biodiversity, among corporations, research organizations and indigenous people (Palacio et al., 2005; Zerda \& Forero, 2002). As anthropologist Brush (1993, p. 658) states: "Since the biological resources of indigenous people are increasing in value to industrial countries, why should indigenous people continue to operate under the common heritage principle by providing their knowledge and resources as free goods?".

Simpson (1997), consistent with Brush (1993), sets out three possible ways to compensate indigenous knowledge in negotiations with modern organizations. The first is direct compensation agreed upon between indigenous communities and organizations, which generally seeks a market transaction and when indigenous people are in disadvantage. 
The second came to the Third World Network proposal in the 90s (Zerda \& Forero, 2002) and the Food and Agricultural Organization - FAO. This proposal steers governments to define a type of trusteeship between indigenous peoples and relevant State agencies to invest in development projects. The third is a bottom up approach where indigenous customary law based on their ability and organization, as well as support from public and private organizations on legal issues, negotiates and makes their arrangements in keeping with their own will.

One of the key points in the discussion on the negotiation of traditional knowledge and biodiversity is to understand the vision on this issue with the indigenous leaders. In 2005 the Misak Guambiano community living in the department of Cauca in Colombia, as stated by de la Cruz (2006), issued the following statement on its website:

"We live with biodiversity, we live by it, and we keep it without destroying it in a sustainable way ... because these are our sacred and ceremonial sites. ... Because the Earth is our mother and mother is not exploited, is not traded, not sold, because we would be destroying its spirit and our essence, so we cannot allow you to extract and use its resources to patent and privatize living by destroying biodiversity. For this reason we fully protect what is our Mayor Right. And for the same reason we organize ourselves better every day, with more strength, to defend with honor and dignity these resources, which are not the product of men but of our gods. They left them to serve us, and for us to care for and manage them and not to exhaust them, sell them or allow others to expropriate. The world has been witness to our struggle to improve our lives.. "1

de la Cruz (2006) argues that many similar statements have been made by indigenous peoples of the Andes, Amazon and in general from other regions in the world. Organizational skills, as they themselves acknowledge, are essential to ensure respect for their rights. Certainly statements such as the International Indigenous Forum on Biodiversity (IIFB) ${ }^{2}$, organization discussed below, are clear in stating that:

"...our collective knowledge is not a commodity to be traded like any object in the market. Our knowledge of biodiversity is indivisible from our identities, laws, institutions, value systems and worldviews as Indigenous Peoples. For generations, our peoples have been and remain the guardians of nature from which we all depend. We are therefore totally committed to the first two objectives of the Convention which are the conservation and sustainable use of biodiversity. But any discussion of the third objective on access and benefit sharing must recognize the fundamental rights of indigenous control of our own knowledge, the right of free prior informed consent as peoples and our collective territorial rights" 3 .

Traditional knowledge is understood then, as invaluable in the field of goods, given that it is indivisible and not individually appropriated. This knowledge is part of the same traditions of the people and their ways of interacting with their environment. In itself this knowledge governs a lifestyle, an identity that can not be alienated or lost because it is the mechanism for continued community dignity.

The intellectual property system that enshrines the individual's monopoly of knowledge clashed with the ways in which indigenous peoples understand their resources and their environment. Although there are success stories like the Shaman Pharmaceutical Company in Ecuador and Colombia, as well as Merck and INBio in Costa Rica (Landon, 2007), most

\footnotetext{
${ }^{1}$ http://colombia.indymedia.org/news/2005/11/33423.php Retrieved February 25, 2011

2 http:/ /iifb.indigenousportal.com/about/ Retrieved February 25, 2011

${ }^{3}$ http:/ / www.prodiversitas.bioetica.org/doc59.htm Retrieved February 25, 2011
} 
cases result in biopiracy and patent litigation (Restrepo, 2006) or in simple exchanges that do not suitably compensate the value of genetic resources (Zerda \& Forero, 2002). Negotiations among indigenous communities and other organizations are difficult because the former are not used to thinking in terms of profits or revenue sharing. It is also unclear how specific communities are the exclusive possessors of the resources, and what benefits are to be received in case of finding commercial uses of biodiversity. Finally, there is no clear institutional framework for negotiations and deals which have impeded the sustainable use of biodiversity (Palacio et al, 2005).

The Andean region has formed the Indigenous Working Group on Biodiversity of the Andean Community (CAN), which proposed that "...given the characteristics of traditional collective and comprehensive knowledge of indigenous people, it is recommended for their protection the use of their ancient systems, that is, on the basis of customary law and cultural practices of their own, allowing communities to strengthen their traditional strustures." (cited by de la Cruz, 2006, p. 7).

Customary law is a foundation of collective rights formed by the habits of a population. Unlike positive law, which focuses on the writing of laws, customary law rests on the cultural background and knowledge to establish traditional standards of behavior. Developing a form of intellectual property rights, collective and fair with traditional knowledge and genetic resources used by the natives, and entering into dialogue with the positive law, is a very important issue today. The negotiations of indigenous communities are very varied making it necessary to not only consolidate indigenous organizations, but also to support regulation and enforcement of indigenous rights (Palacio et al, 2005; Zerda \& Forero, 2002) The only country with progress in this area is Peru (de la Cruz, 2006), which in 2004 created the National Commission for the Protection of Access to Peruvian Biological Diversity and the Collective Knowledge of Indigenous Peoples working with other indigenous organizations in Peru in the negotiations and demands for rights.

Zerda \& Forero (2002) understood that the 'Alternative Proposals' to the Third World Network will not help the development of the deals and negotiations between indigenous people and other actors. The authors call for institutional and organizational strengthening of indigenous communities, and predicted the creation of international organizations that represent indigenous matters as the CBD. Progress in indigenous law is accompanied by the organizational capacity of communities to represent and defend their interests and rights. Organizations are the means to steer governance in their own affairs.

\subsection{The organization of indigenous peoples}

Indigenous peoples since the nineteenth century in the nascent American republics have been defending their rights to preserve their lands, livelihoods, culture and resources. Undoubtedly, new organizational forms will enter to define the way in which indigenous peoples can increase the power of governance over their own destiny. As noted, the negotiations between indigenous communities and organizations for research and production have a profound inequality, and eventually run relationships where the indigenous community will never receive benefits, unless it is properly organized.

The mechanism by which communities have preserved their traditions, cultures and forms of social reproduction have been through regional organizations of indigenous peoples. These organizations in the Andes began to appear since the 1980's to differentiate themselves from the farming peasants and have an entity, legally capable of representing 
their rights at national and international level (Yashar, 1998). For example, Colombia's indigenous regions of Cauca, Chocó, Sierra Nevada, Córdoba, Llanos Orientales and Tolima gathered in 1982 to create the National Indigenous Organization of Colombia - ONIC (http://www.onic.org.co/nuevo/sobrenos_n.shtml), which currently represents all the country's indigenous communities. Similar cases occurred with the Confederation of Indigenous Nationalities of Ecuador (http://conaie.nativeweb.org/) and the National Indian Council of Venezuela - CONIVE (http://www.conive.org/). Also, organizations have been established in eco-geographic order like COICA (Coordinating Body of Indigenous Organizations of the Amazon Basin), which rises in response to the Amazon Cooperation Treaty signed in 1978 by the Amazon basin countries. The treaty did not consider the indigenous peoples, who finally organized themselves in the creation of COICA in 1984.

Organizations have enabled indigenous peoples to have a capacity of voice and collective defense of their rights. Support of States, various NGOs and various grants and contributions has allowed indigenous organizations to have communication channels and means of negotiating with modern society. One of the most relevant businesses for indigenous communities is to govern their natural resources and traditional knowledge, additional development of indigenous law, and legal organizations represented are the mechanisms to accomplish this.

For example in Peru, the National Institute for the Defense of Competition and Intellectual Property Protection INDECOPI established the program "Towards the effective protection of the collective knowledge of indigenous peoples", which provides training in indigenous law and forms of negotiation, as well as ways to protect the property of their resources. In early 2000, the company PureWorld Inc U.S. patented applications and uses of maca, a plant native of Peru. Thanks to the management of INDECOPI and the National Commission for the Protection of Access to Peruvian Biological Diversity and the Collective Knowledge of Indigenous Peoples, the patent was promptly canceled because it was recognized that there is no change or novelty from the holder different from that of the Peruvian indigenous peoples who have cultivated this species since ancient times (Landon, 2007).

Also, is worth to remember the famous case of Yage or Ayahuasca, which is a root of an Amazonian tree whose medical effects are sacred in the ceremonies of the Amazon tribes. In the early 1990's a California man named Loren Miller obtained the patent for yage to be exploited by his company, the International Plant Medicine Corporation. By the end of the 1990s, pronouncements by indigenous peoples and their organizations on the subject were strong and repeated (Muelas, 1997). In 1999 the Center for International Environmental Law - CIEL, an American organization, represented COICA and the Coalition for Amazonian People and Their Environment (Amazon Coalition) in applying to revoke the patent.

There are at least 30 large organizations with international prominence, serving different indigenous issues. One of the most important is the International Indigenous Forum on Biodiversity [IIFB] (http://iifb.indigenousportal.com/about/) created in 1996 for negotiations on the Convention on Biological Diversity. This organization works for states to enable them to respect, preserve and maintain traditional knowledge and biodiversity management. As mentioned before, the Andean countries created the Indigenous Working Group on Biodiversity of the Andean Community (CAN). This body is responsible for matters related to the Andean Decision 391 on traditional knowledge and genetic resources of biodiversity in indigenous communities. 
In October 2010 the IIFB ended the Nagoya Protocol to be signed in 2011 and 2012 to regulate the issues of fair and equitable compensation of benefits arising from the use of genetic resources and biodiversity. In this regard the IIFB declared on October 29, 2010 that:

"With the adoption of the Nagoya Protocol on Access to Genetic Resources and Fair and Equitable Sharing of Benefits, governments have enacted international legislation in relation to genetic resources and the associated traditional knowledge. Indigenous people and local communities have spiritual values, ethical standards, and rights under customary laws that guide us in the use of our lands, territories, resources and traditional knowledge, which must be respected. The parties have agreed to take action under national law to uphold the law, human rights and Indigenous People to protect traditional knowledge. But there is more to do to stop biopiracy. Look forward to working with governments for fair and meaningful implementation"4.

The continuity of worthy life in communities depends on their ability to organize, to exercise their form of customary law, and has to impact on the level of legally binding negotiations. Also, it is important for indigenous peoples to enhance their capacity to have voice and communicate. In this aspect, the World Summit on the Information Society declared explicitly the importance of "exploring the viability of establishing multistakeholder portals for indigenous people". Furthermore, launch education and training programs for indigenous people to provide them participation in the Information Society. The initiative also stated the development and implementation of policies "to preserve, affirm, respect and promote the diversity of cultural expression and indigenous knowledge and traditions through the creation of varied information content and the use of different methods, including the digitization of the educational, scientific and cultural heritage", enhancing "the capacity of indigenous peoples to develop content in their own languages", and finally "cooperate with indigenous peoples and traditional communities to enable them to more effectively use and benefit from the use of their traditional knowledge in the Information Society" (WSIS, 2003).

\section{References}

Bernal, H.Y.; García, H. \& Quevedo, F. (2011). Pautas para el conocimiento, conservación y uso sostenible de las plantas medicinales de Colombia. Primera edición. Instituto de Recursos Biológicos "Alexander von Humboldt". Bogotá, D.C., Colombia. 300 p. aprox. In press.

Bovarnick, A., F. Alpizar, C. Schnell, Editors. (2010). The Importance of Biodiversity and Ecosystems in Economic Growth and Equity in Latin America and the Caribbean: An economic valuation of ecosystems. Executive Summary. United Nations Development Programme [UNDP]. $24 \mathrm{p}$.

Brush, S.B., (1993). Indigenous knowledge of biological resources and intellectual property rights, the role of anthropology. American Anthropologist, 95, pp. 653-686

CAN - Comunidad Andina de Naciones. (2002). Decision 523 - Regional Biodiversity Strategy for the Tropical Andean States. Available at:

http://www.comunidadandina.org/ingles/normativa/Decision523e.pdf

\footnotetext{
${ }^{4}$ http:/ /iifb.indigenousportal.com/2010/11/07/declaracion-de-clausura-del-foro-internacionalindigena-sobre-biodiversidad-fiib/\#more-389 Retrieved Februery 24, 2011.
} 
CBD - Convention on Biological Diversity. (2000). Sustaining life on Earth: How the Convention on Biological Diversity promotes nature and human well-being. Secretariat of the Convention on Biological Diversity, 20 p. ISBN 92-807-1904-1

Cheng, C.L., Guo, J.S., Luk, J. \& Koo, M.W.L. (2004). The healing effects of Centella extract and asiaticoside on acetic acid induced gastric ulcers in rats. Life Sci. 74, 2237-2249

Chi-Rei, W, Wen-Hsin, L., You-Cheng, H., Jin-Cherng, L , Yung-Ta, L., Tzu-Ping, K, \& Hui, C. (2011). Evaluation of the antioxidant activity of five endemic Ligustrum species leaves, from Taiwan flora in vitro. Food Chemistry 127: 564-571

Corporazione italiana de Vida; Inrena, IUCN, Cesvi; Pro naturaleza: (2008) Estudio Etnobotánico en las cuencas altas de los ríos Tambopata e Inambari. Lima Peru

Correa, J.E. \& Bernal, H.Y. (1990) Especies vegetales promisorias de los países del Convenio Andrés Bello. Tomo 1. $1^{a}$ edición. Editora Guadalupe Ltda. Bogotá, Colombia p.400-419

Damiano R., Alessandra G., Silvia M., Renato B., Guglielmo P.,Ferruccio P., Laura S., Matteo R., Katia S., Gianni S. (2011). Chemical fingerprinting and bioactivity of Amazonian Ecuador Croton lechleri Müll. Arg. (Euphorbiaceae) stem bark essential oil: A new functional food ingredient? Food Chemistry $126: 837-848$

de la Cruz Lapa, P. (2004). Aprovechamiento Integral y Racional de la Tara. Caesalpinia spinosa - Caesalpinia tinctoria. Revista del Instituto de Investigación FIGMMG. Vol. 7, N. ${ }^{\circ}$ 14, 64-73 Universidad Nacional Mayor de San Marcos. ISSN: 1561-0888 (impreso) / 1628-8097 (electrónico)

de la Cruz, R. (2006). Conocimientos tradicionales y derecho consuetudinario. Unión Mundial para la Naturaleza. Available at:

http:/ / www.rimisp.org/getdoc.php?docid $=6584$

Dove, M. (2006). Indigenous people and environmental politics. Annual Review of Anthropology. 35, pp. 191:208.

FAO - Food and Agriculture Organization of the United Nations. (1994) Neglected crops: 1492 from a different perspective. Edited by J.E. Hernández Bermejo and J. León. ISBN $92-$ 5-103217-3. Available at: http://www.fao.org/docrep/t0646e/T0646E0d.htm

FAO - Food and Agriculture Organization of the United Nations. (2011b). The state of food and agriculture 2010-2011. Women in Agriculture: Closing the gender gap for development. 160 p. ISBN 978-92-5-106768-0

FAO - Food and Agriculture Organization of the United Nations. (2004). The state of food and agriculture 2003-2004. Agricultural Biotechnology: Meeting the needs of the poor? FAO Agriculture Series No35. 209 p. ISBN 92-5-105079-1.

FAO. (2011a). Status and trends of biotechnologies applied to the conservation and utilization of Genetic Resources for food and agriculture and matters relevant for their future development. Doc CGRFA/WG-PGR-5/11/4, Fifth Session Intergovernmental Technical Working Group on Plant Genetic Resources for Food and Agriculture, Commission on Genetic Resources for Food and Agriculture. Available at: http://www-

data.fao.org/ag/againfo/programmes/en/genetics/angrvent2010.html

Fjeldsa J, Alvarez MD, Lazcano JM, Leon B (2005). Illicit crops and armed conflict as constraints on biodiversity conservation in the Andes region. Ambio 34(3):205-211

Grajal, A. (1999). Régimen de Acceso a Recursos Genéticos Impone Limitaciones a la Investigación en Biodiversidad en los países Andinos. Interciencia, Vol. 24, No. 1, (Jan-Feb 1999), pp. 63-69, ISSN 1515-1050. 
Gupta, M. (2008). Plantas medicinales iberoamericanas. Centro de Investigaciones Farmacognósticas de la Flora Panameña. Facultad de Farmacia. Universidad de Panamá, República de Panamá, CYTED, Convenio Andrés Bello p 336-338

Hodson de Jaramillo E. (2009). Ecological Aspects of Biosafety. In: Biosafety of Genetically Modified Organisms: Basic Concepts, methods and issues. Chowdhury MKA, Hoque MI \& Sonnino A (Eds.) pp 51-105 (C) FAO 2009. ISBN 978-92-5-106447-4

Inamdar, P.K., Yeole, R.D., Ghogare, A.B. \& de Souza, N.J. (1996). Determination of biologically active constituents in Centella asiatica. J. Chromatogr. A 742, 127-130

Jahuira H., Viviana R. (2005). Uso y consumo de plantas medicinales en comunidades campesinas del altiplano de Puno - Perú". Maestría en Ciencias Sociales con mención en Asuntos Indígenas; FLACSO sede Ecuador. Quito. $131 \mathrm{p}$

Landon, AJ. (2007). Bioprospecting and Biopiracy in Latin America: The Case of Maca in Perú. Nebraska Anthropologist. Paper 32. Available at: http:/ / digitalcommons.unl.edu/nebanthro/32 (26)

Lu, L., Ying, K., Wei, S., Fang, Y., Liu, Y., Lin, H.,Ma, L. \& Mao, Y. (2004). Asiaticoside induction for cell-cycle progression, proliferation and collagen synthesis in human dermal fibroblasts. Int. J. Dermatol. 43, 801-807.

Montagut, X y Dogliotti, F. (2006). Alimentos globalizados. Soberanía alimentaria y comercio justo. Ed. Icaria, Barcelona.

Muelas, L. (1997). Patente del Yagé. Revista Semillas, 9: 30-33. Available at: http:/ / www.semillas.org.co/sitio.shtml?apc=a1a1--\&x=20154743.

Munduvelil, T, T, Rajani, K., Anil, J, J., Sreeja, P, C. , Paravanparampil, J.M., Mathew, D. \& Sabulal, B. (2010). Elite genotypes/chemotypes, with high contents of madecassoside and asiaticoside, from sixty accessions of Centella asiatica of south India and the Andaman Islands: For cultivation and utility in cosmetic and herbal drug applications. Industrial Crops and Products 32:545-550.

Naveh, Z. (1998). Ecological and cultural landscape restoration and the cultural evolution toward a post-industrial symbiosis between human society and nature. Restoration Ecology 6:135-143.

Palacio, L.; Cortes, A. y Gómez, F. (2005). Conocimiento Tradicional y Comunidades Locales. In: Nemogá G. R (Ed.). Negociación Contratos de Acceso, Conocimiento Tradicional y Comunidades Locales Universidad Nacional de Colombia. Bogotá. (Serie Documentos de Investigación. Recursos Genéticos, Conocimiento y Derechos No. 2).

Restrepo, C. (2006). Apropiación indebida de recursos genéticos, biodiversidad y conocimientos tradicionales: biopiratería. Universidad Externado de Colombia. Bogotá.

Roig., J.T. (1988). Plantas aromáticas o venenosas de Cuba. Segunda Edición Editorial Científico Técnica. La Habana-Cuba. p. 601-602

SGRP - System-wide Genetic Resources Programme. (2010). Booklet of CGIAR Centre Policy Instruments, Guidelines and Statements on Genetic Resources, Biotechnology and Intellectual Property Rights. Version III. System-wide Genetic Resources Programme (SGRP) and the CGIAR Genetic Resources Policy Committee (GRPC). Bioversity International. Rome, Italy. Available at: http://www.sgrp.cgiar.org/sites/default/files/Policy_Booklet_Version3.pdf 
Shukla, A., Rasik, A.M., Jain, G.K., Shankar, R., Kulshrestha, D.K. \& Dhawan, B.N. (1999). In vitro and in vivo wound healing activity of asiaticoside isolated from Centella asiatica. J. Ethnopharmacol. 65: 1-11

Simpson, T. (1997). Patrimonio indígena y autodeterminación. IWGIA, Copenaghen.

Suffness M., Abbot, B. et al (1988). The utility of P388 leukemia compared to B16 melanoma and colon carcinoma 38 for in vitro screening of plant extract. Phytotherapy Res. 2(2)89-97

The National Academies USA. (2007). New Horizons in Plant Sciences for Human Health and the Environment. CBD Technical Series No. 53. Available at: http:/ / www.nationalacademies.org/plant_genome

UNDP - United Nations Development Programme. (2010a). The Importance of Biodiversity and Ecosystems in Economic Growth and Equity in Latin America and the Caribbean: An economic valuation of ecosystems. Executive Summary. Available at: http:/ / www.bioone.org/doi/full/10.3417/2009065.

UNDP - United Nations Development Programme. (2010b). Latin America and the Caribbean: A biodiversity Super Power. A Policy Brief. $18 \mathrm{p}$.

UN Millennium Project (2005). Investing in Development: A Practical Plan to Achieve the Millennium Development Goals. Overview. Available online at: http:/ / www.unmillenniumproject.org/

Wahlberg, I and Enzell, C.R., 1971, 24 or 24-xi-2-ocotillone, a triterpenoid from comercial tolu balsam. Myroxylon balsamum. Acta Biochem. Vol. 25 (1) 352-354

WSIS (2003). Geneva Plan of action. World Summit on the Information Society. Document WSIS-03/GENEVA/DOC/5-E.

Yashar, D. (1998). Contesting citizenship: Indigenous movements and democracy in Latin America. Comparative Politics, 31, pp. 23-42.

Zerda-Sarmiento, A. and Forero-Pineda, C. (2002). Intellectual property rights over ethnic communities' knowledge. International Social Science Journal, vol. 54, no. 171, pp. 99114

Zimmerer, K. (1993). "Agricultural biodiversity and peasant rights to subsistence in the central Andes during Inca rule». Journal of Historical Geography 19, pp. 15-32.

Zimmerer, K. (1999). Changing fortunes: biodiversity and peasant livelihood in the Peruvian Andes. Berkeley: University of California Press. 


\title{
European Naturalists and Medicinal Plants of Brazil
}

\author{
Maria G. L. Brandão ${ }^{1}$, Cristiane F. F. Grael ${ }^{2}$ and Christopher W. Fagg 3 \\ ${ }^{1}$ Faculdade de Farmácia \& Museu de História Natural e Jardim Botânico, \\ Universidade Federal de Minas Gerais, Belo Horizonte \\ ${ }^{2}$ Departamento de Farmácia, Universidade Federal dos Vales do Jequitinhonha e Mucuri, \\ Diamantina \\ ${ }^{3}$ Faculdade de Ceilandia \& Departamento de Botânica, Universidade de Brasília, Brasília,
}

Brasil

\section{Introduction}

Plants have been used as a food and medicinal source in the Americas for a long time. Historical registers demonstrate that Amerindians used avocado (Persea americana L.), sweet potatoes (Ipomoea batatas (L.) Lam.), mate (Ilex paraguariensis A. St.-Hil.) and cacao (Theobroma cacao L.) 10,000 years ago (Wolters, 1992). The Portuguese and Spanish brought several of these species to Europe at the beginning of the $16^{\text {th }}$ century. There, they began to investigate the native beliefs about disease and the plants that cured them. The use of Brazilian plant remedies, such as copaiba (Copaifera spp.), jaborandi (Pilocarpus spp.), ipecacuanha (Psychotria ipecacuanha (Brot.) Stokes) and curares (Chondodendron spp.), have expanded to several parts of the world. In addition to the dissemination of knowledge, the plant remedies themselves were transported in great quantity (Ferrão, 2004). Medicinal plants are widely used in both rural and urban areas of Brazil. However, the intense miscegenation of cultures over the last centuries has popularized the use of exotic and imported plants in medicine. Most plants are used according to folk tradition, which was brought to the country by Europeans and Africans, popularizing European than indigenous medicine. Moreover, the growth of the pharmaceutical industry in Brazil during the second half of the 20th century markedly changed traditional Brazilian medicine.

Brazil's native vegetation is continuously suffering destruction in consequence of different economic cycles (Machado \& Figuerôa, 2001). The first economic cycle in Brazil was due to the exploitation of redwood ("pau-brasil") along the coast by the Portuguese since the discovery of the country, lasting over 50 years. The wood of this species provides a deep red color, which was much used at the time to dye cloth, and more recently the only true wood for violins bows. In the second half of the 16th century the sugarcane plantations started, indicating that Portugal was really motivated to settle Brazil. For a period exceeding 150 years, sugar production accounted for almost the sole basis of the Brazilian economy. Actually, in the middle of the 17th century Brazil was the world's largest sugar producer, and at that time the first competitors started their production in Central America and the Caribbean. The third economic cycle is more or less simultaneous with the sugarcane cycle 
and is due to cattle grazing, occupying vast territories in Brazil, initiating the march towards the west. Then gold gave rise to the fourth economic cycle at the end of the 17th century, after the discovery of rich alluvial deposits in Minas Gerais. For some authors, diamonds is responsible for the fifth economic cycle, starting in 1729 and lasting 140 years, until South Africa emerged as the major producer. It is considered that in the 17th and 18th centuries, Brazil contributed ca. $50 \%$ of the world production of gold and diamonds, promoting the prosperity and luxury of the Portuguese crown. At that time, baroque art flourished in Minas Gerais, with Ouro Preto the most outstanding monument of this glorious past. Coffee gives its name to the sixth economic cycle, and the first large-scale plantations began in 1835, after the independence of Brazil from Portugal (Dean, 1996). Finally, in the last years of the 19th century rubber production started in the Amazon, giving rise to the seventh economic cycle. After this cycle, our economy became so diversified through industrialization that it would not be adequate to define more specific cycles as such. Currently, however, several projects, including the expansion of ethanol production, mining and Soyabean cultivation, threaten what remains of the native vegetation (Martinelli et al., 2010; Sawyer, 2008). With the exception of rubber, all of these processes have brought serious consequences to the native vegetation in Southeastern Brazil.

In a recent study, we evaluated the knowledge of the population in the mining region of Minas Gerais (Royal Road) on several species of native medicinal plants described by the work of naturalists. We interviewed 152 men and 54 women, between 65 and 90 years of age, recognized as experts on the native medicinal plants. These people were born before the 1940s, i.e., prior to the urbanization and industrialization of Minas Gerais and to the introduction of large-scale drug manufacturing, which has been occurring in Brazil since the 1950s. Each informant was asked whether he knew and/or has used any of the 20 species of native plants registered in the $19^{\text {th }}$ century, and if so, where they were collected. The survey demonstrated that the population knew little to nothing about most of the surveyed species or their current applications. Almost all of the respondents learned about medicinal plants from their families, but their descendants were not interested in pursuing this knowledge. A small percentage of younger respondents $(5 \%)$ revealed that knowledge about these plants was not being passed to new generations. Our study showed that some of the plants of the Royal Road remain unknown today, as is the case with Zanthoxylum tingoassuiba A. St-Hil. (Rutaceae, tinguaciba), which went unrecognized by all informants. In contrast, some species that were described by the naturalists are currently known and used. However, their uses differ from past applications (Santos et al., 2011). This survey reveals the urgent need to recover the information describing the utility of the native plant species and to promote further studies on their ecology and conservation (Giulietti et al., 2005; Michalski et al., 2008).

Historical research can be vital for recovering valuable ethnopharmacological data regarding the use of plants (Medeiros, 2008). Much of the available information about the use of native medicinal plants in Brazil has been compiled by European naturalists that traveled throughout the country in the 19th century. The data recorded in their books served as an important source of information about the use of plants. At that time, the native flora was conserved, and Brazilian species were predominantly used. The contributions to the understanding of Brazilian flora made by these naturalists are incalculable. Hundreds of new plants were discovered, and innumerable new genera were described based on the material that they collected. Several naturalists have traveled widely in the southwest 
province of Minas Gerais and have recorded both the biological and mineral richness of the region (Brandão et al., 2008b). The main objective of our research group is to retrieve and disseminate information and images of useful native species (www.dataplamt.org.br). In this script, we discuss the important work undertaken by European naturalists, who traveled through Brazil in the nineteenth century recording plant knowledge and their uses.

\section{A brief history}

Brazil was a Portuguese colony between 1500 and 1822. Most of the information about the uses of native plants was collected by the Jesuits during Brazil's colonization. They were the first to have direct contact with the Amerindians since the beginning of colonization. The Jesuits attracted the attention of the Portuguese repeatedly in their reports on the potential and utility of Brazilian medicinal plants. For example, the Theriacs, electuaries prepared by mixing the extracts of many plants, originated from ancient Rome and have been used as remedies for all kinds of envenomation. The Jesuits have incorporated Native American species in this remedy, termed "Triaga Brasilica", which was used to treat fevers and venom from snakes and other animals (Pereira et al., 1996). In the seventeenth century, Northeast Brazil was invaded by the Dutch. The doctor William Piso lived in this region for eight years, and in his book "Historiae Naturalis \& Medicae", published in 1648 in Holland, he described the uses of various native plants by the Amerindians (Pisonis, 1648). The data contained in this work remains a major source of information on the biodiversity in Brazil throughout the late 18 th century.

Brazil remained under the rigid control of the Portuguese until the early nineteenth century. This policy was intended to hide the potential of the natural resources from other nations. The German naturalist Alexander von Humboldt, who extensively explored northern South America from 1799 to 1804 (Humboldt, 1993), was banned from entering Brazil, indicative of this strict policy. Instead, Portugal sent Brazilian Alexandre Rodrigues Ferreira, who had traveled the Brazilian Amazon and the Pantanal for ten years to collect information and native plant and animal specimens (França, 1922). In 1808, Bonaparte's invasion of Portugal drove the Portuguese royal family to re-settle in Rio de Janeiro. There was remarkable progress in the economy and in culture and science during the thirteen years that they lived in Rio de Janeiro, wherein foreigners gained permission to enter the country. Several European naturalists, artists and scientists traveled the vast Brazilian territories, registering the mineral, animal and vegetal resources as well as the customs of the inhabitants. Thus, a cycle of scientific expedition sponsored by different nations began the systematic production of works in Brazil. The information gathered by naturalists contributes greatly to the growing knowledge of South American biodiversity and has led to significant advances in understanding the continent's natural history.

The naturalists were supported by the governments of their countries. Furthermore, the liberalism of the Portuguese court in Rio de Janeiro promoted incentives to attract scientific missions. The lack of skilled personnel in Brazil, due to centuries of colonial dependency and exclusivity imposed by Portugal, developed the need for the services offered by foreigners. Different interests attracted European naturalists to Brazil. Some came following the European court, such as Pohl and von Martius, whereas others were invited to come to work, such as Mawe, Saint-Hilaire and Burton. The large numbers of travelers, scientists and artists that arrived at the port of Rio de Janeiro, the main port of arrival, prohibit us from knowing precisely how many came to Brazil during at that time. Once having explored 
Rio de Janeiro, travelers were interested in penetrating into the interior of the country, primarily into the mining zone in Minas Gerais (Leite, 1996).

Twenty-four foreign naturalists are known to have traveled through Minas Gerais during the $1^{\text {th }}$ century, which is particularly interesting due to its status as the world's largest gold producing region at that time. Production strongly declined when new areas became available for mining in California, Australia, South Africa and Alaska. Consequently, new economic activities prevailed, such as agricultural development, described by naturalists Saint-Hilaire and Mawe, and included a greater substitution of native vegetation by sugar cane, coffee and cattle grazing. Despite the exhaustion of gold, incentives to create innovate techniques for exploring deeper auriferous and iron veins persisted.

Thus, the province of Minas Gerais was heavily visited by European naturalists throughout the nineteenth century. Their bibliographies document their observations about the various aspects of Brazilian life, including the use of medicinal plants. Today, the State of Minas Gerais, whose area is approximately that of France, is the second most industrialized in Brazil and was the most populated until 1940, when São Paulo's industrial growth began to polarize national migration flows. Minas Gerais exhibited a remarkable ecological diversity. Four of Brazil's six main biomes occur in Minas Gerais, viz. the Atlantic Forest in the East, savannas in the West, Caatinga in the North, and Araucaria Forests in the South. Consequently, hundreds of medicinal plant species were available, a situation different from that observed today because most of the medicinal plants used by the population are exotic (Brandão et al., 2006a; Rodrigues \& Carvalho, 2007; Schmeda-Hirschmann \& Arias, 1990; Stehmann \& Brandão, 1995). Prior to the 19th century, $45 \%$ of the territory was covered by forests and extensive unexplored savannas, and a strong interaction between the native Amerindians and the more recently arrived inhabitants of the agricultural areas remained. This interaction was vital for the success of the expeditions conducted by visiting naturalists. The locals assisted with locating and identifying plants by sharing the popular nomenclature and indicating the best regions for research (Moreira, 2002). The native knowledge of the plants and their uses was mentioned by several naturalists. For example, Saint-Hilaire discussed the necessity of creating commissions to document how the plants were used by the native people (SaintHilaire, 1824a, 1824b).

These naturalists' diaries demonstrated the extensive use of Amerindian medicinal plants by the population. According to some authors, the knowledge about the Amerindian medicinal plants held by the natives was the only aspect of their culture that was respected by the Portuguese. Undoubtedly, one of the biggest naturalistic interests of that period was to learn from the Brazilian population the medicinal utilities of their plants, as Saint-Hilaire states:

"in all part that I stopped, I had always the care to ask which were the plants most used in the region"

Viagem pelos distritos dos diamantes e litoral do Brasil (Journey through the diamond district and the coast of Brazil)

Saint-Hilaire, 1975a

However, the intense mining, extensive cattle ranching and coffee plantation development during the $18^{\text {th }}$ century through the $20^{\text {th }}$ century culminated in the substitution of much of the state's native vegetation by pastures, agriculture and eucalyptus monoculture reforestation. Today, almost 600 plant species are approaching extinction in Minas Gerais (http://www.ibama.gov.br). 


\section{The European naturalists that traveled throughout Minas Gerais}

Most European naturalists that described the use of medicinal plants, who traveled in the state of Minas Gerais in nineteenth century, were Austrian, German, English and French. They arrived in Brazil interested in studying the natural resources of Brazil and assessing their potential utility. Arriving at Rio de Janeiro, after several excursions through the coastal area, naturalists traveled to other sites, including large tracts of the vast Brazilian territory.

In 1817, the marriage of the daughter of the King of Austria (Leopoldina) to the heir of Portugal (Pedro I) promoted a visit by a delegation of Austrian and German naturalists, including Johann Emanuel Pohl (1782-1834) and K. F. von Martius (1794-1868). Pohl was a botanist who resided in Brazil from 1817 to 1821. He left in September 1818, beginning a long journey through the provinces of Minas Gerais, Goias, Mato Grosso and Para, which was one of the greatest journeys made in Minas Gerais in the nineteenth century (Pohl, 1976). He documented his observations on the Brazilian flora in "Plantarum Brasiliae Icones et Descriptions" in 1827 (Pohl, 1827). Karl Friedrich Philipp von Martius journeyed with Johann Baptist von Spix throughout much of the country, traveling over 10,000 kilometers from 1817-1820. They travelled from Rio de Janeiro toward São Paulo, Minas Gerais, Bahia, Pernambuco, Piaui, Maranhão, Para and Amazonas. Spix was a zoologist and the curator of a museum in Munich. They published several books in the fields of botany and zoology. Before he died, six years after returning to Europe, he documented almost all of their travels, along with Martius. The "Flora Brasiliensis", organized by von Martius, describes twenty thousand species, six thousand of which were unknown at that time (Spix \& Martius, 1981; www.florabrasiliensis.cria.org.br).

The German physician G.H. von Langsdorff's (1774-1852) expedition was integrated by the illustrator Rugendas and the botanical Riedel, who was in charge of the collection and registers of the American plants. The Amerindian use of plants was infrequently documented in his travel diaries (Silva, 1997a, 1997b, 1998). He was the Consul General of Russia and lived on the outskirts of Rio de Janeiro from 1813. He enthusiastically supported and promoted scientific explorations and traveled from São Paulo to Pará, passing through Mato Grosso. In 1815, Maximilan von Wied-Neuwied arrived in Rio de Janeiro to explore the Brazilian coast with funding from European museums (Neuwied, 1989). He was accompanied by the zoologist Freireyss (1789-1825). Georg Wilhelm Freireyss was an organizer of zoological and botanical collections of the Museum of Stockholm. In 1814, he journeyed to Minas, passing through Villa Rica and the tribes of the Coroados and Puris (Freireyss, 1982). The zoologist Hermann Burmeister (1807-1898) arrived in Brazil in late 1850. He stayed for five months as a monitor of Danish Peter W. Lund, who had explored paleontological traces in Lagoa Santa since 1834 (Burmeister, 1958).

Several English naturalists who visited Brazil in the nineteenth century and recorded the use of medicinal plants, including John Mawe, Charles Fox Bunbury, George Gardner and Richard Burton. John Mawe (1764-1829) was the first to obtain permission to travel to Minas Gerais. He arrived in 1807 with extensive experience in working and traveling in the mines of England and Scotland in search of specimens for a mineralogical collection of the King of Spain. He was in Brazil between 1807 and 1811, and although he was not a specialist in botany, his book extensively describes the use of medicinal plants (Mawe, 1978). Charles James Fox Bunbury arrived in Rio de Janeiro in July 1833 and stayed there until December, when he embarked for the River Plate, visiting Montevideo and Buenos Aires. He returned to Brazil in 1834, where he began preparations for his trip, and left for the interior to explore the British gold mines. $\mathrm{He}$ 
returned to Europe in January 1835 (Bunbury, 1981). The botanist George Gardner (1812-1849) arrived in Rio de Janeiro in 1838, where he resided for five years, traveling the provinces of Bahia, Alagoas, Pernambuco, Ceará, Piauí, Goiás and northern Minas Gerais (Gardner, 1975). Richard Francis Burton (1821-1890) was an anthropologist, traveler and writer who belonged to the Royal Geographical Society and is best known for his travels in Africa. He frequently journeyed around the country, particularly from Rio de Janeiro to Minas Gerais. Part of the route was made by canoe, from Sabará to the Atlantic Ocean, the Rio das Velhas and São Francisco rivers. He was generally interested in the nature of Brazil and its potential, including the use of medicinal plants (Burton, 1977).

The French botanist Auguste de Saint-Hilaire, born in Orleans in 1779 and died in the Turpinière in 1853, had the opportunity to come to Brazil in the company of the Duke of Luxembourg and was appointed to ambassador in Rio de Janeiro. He arrived in 1816 and returned to Europe in 1822. During this period, he explored the province of Minas Gerais and then headed south, crossing the provinces of Rio de Janeiro, Sao Paulo, Santa Catarina, Rio Grande do Sul and Uruguay. In addition to observing the collection of botanical material, he never failed to record the habits and customs of the habitants. He was very concerned about the deforestation leading to grazing and other activities occurring at that time. He returned to France carrying 7,000 plants, 2,500 birds, 16,000 insects, 129 quadrupeds, 35 reptiles, 58 fish and shellfish and various minerals to contribute to the Museum of Paris. Saint-Hilaire dedicated the rest of his life to the study of the material collected during these trips and to teaching as a professor of botany at the School of Sciences in Paris. Francis de la Porte Castelnau was born in 1812 in London, but his family belongs to the aristocracy of Central and Southern France. His studies in Brazil primarily included geology and zoology, but he also collected ethnographic information on the tribes and cultures that he visited. He explored the provinces of Minas Gerais, Goias and Mato Grosso. Alcide Dessalines d'Orbigny was born on the outskirts of Nantes, France in 1802 and died in Seine-Saint-Denis on 1875. He was the son of a physician and an amateur naturalist, becoming interested in natural sciences early in life. In 1820, his family moved to the seaside town La Rochelle, where he began his studies with microscopic marine fauna. Between 1831 and 1834, the 24-year-old D'Orbigny formed part of an integrated mission from the Museum of Natural History in Paris to South America, where he visited Brazil, Argentina, Paraguay, Chile, Bolivia and Peru, when he was twenty-four years old. He returned to France with a collection of over 10,000 objects of natural history (D'Orbgni, 1976).

\section{Naturalist interest in medicinal plants}

During colonial times, most drugs and medicines circulating in Minas Gerais were obtained directly from Portugal. The long distance between Rio and Minas posed several problems, but drugs continued to arrive from Portugal to Rio de Janeiro and Bahia and were transported on mules to the countryside. The process was lengthy, and the difficult transport conditions endangered the quality of the medicines. Throughout the eighteenth century, the medical literature reported the widespread use of native Brazilian drugs, whose virtues had been advocated since the beginning of colonization. Gradually, the apothecaries and surgeons, particularly in Minas Gerais, started to incorporate the herbs into their recipes. Luis Ferreira Gomes, author of Erario Mineral (2002), warned that the "herbs, roots, minerals and animal things have bad conditions and that the pharmacies should develop local drugs that incorporate them. Inhabitants that were practicing medicines in the Province began to describe 
and better understand the local flora and fauna to incorporate them into the medical field. Naturalists traveling to Brazil aimed to examine the local biome using more precise methods, including the Linnaean system of classification (Furtado, 2005). The contribution of these naturalists to the knowledge of the Brazilian flora is incalculable. Hundreds of new plants were discovered, and innumerable new genera were described. Much of the information on the use of the native species of Minas Gerais is described in their bibliographies.

Independent of the work in the field, the European naturalists were interested in recording different aspects of native vegetation, including the use of Brazilian medicinal plants. They recorded more than 300 useful species, especially Burton, Saint-Hilaire and von Martius (www.dataplamt.org.br). Burton and Saint-Hilaire suggested several improved ways to use the natural resources, criticizing the destructive manner used by the Portuguese, and followed by the Brazilians. The use of several medicinal species is described in their traveler books. Von Martius and Saint-Hilaire also documented their thoughts about the use of medicinal plants in "Systema Materiae Medicae Vegetabilis Brasiliensis" (1843) and "Plantes Usuelles des Brasiliens" (1824a), respectively. Thus, von Martius and Saint-Hilaire have significantly contributed to the knowledge of the utility of native Brazilian plants. Besides describing new species, they made comparisons between the Brazilian plants and those commonly used in Europe.

Table 1 presents medicinal species registered by three or more naturalists in Minas Gerais. Data were obtained from the diaries of A. Saint-Hilaire (Saint-Hilaire, 1975a, 1975b, 1975c, 1975d), J. Spix \& K. Martius (1981), R. Burton (1977), G. Gardner (1975), J.E. Pohl (1976), G.H. von Langsdorff (Silva, 1997a, 1997b, 1998), H. Burmeister (1958), A D’Orbigny (1976), C.J.F. Bunbury (1981), J. Mawe (Mawe, 1978), G.W. Freireyss (1982), M.W. Neuwied (1989) and Castelnau (1949). The books that specifically expounded on the use of medicinal plants, "Plantes Usuelles des Brasiliens" (Saint-Hilaire, 1824a) and "Systema Materiae Medicae Vegetabilis Brasiliensis" (Martius, 1854), were also used in the study.

The names of certain species mentioned by J.E. Pohl and A. Saint-Hilaire were confirmed by consulting the original collections in the Natural History Museums in Vienna and Paris, respectively. The names of plants cited by von Martius were verified at the website www.florabrasiliensis.cria.org.br. English names for each species and their family placement were updated using the data from the Missouri Botanical Garden's website Tropicos database at www.mobot.org. The species cited by von Martius and Saint-Hilaire in their books on medicinal plants are marked with an "*”.

\begin{tabular}{|c|c|c|c|c|c|c|c|c|c|c|c|c|c|}
\hline $\begin{array}{l}\text { FAMILY AND SCIENTIFIC/ } \\
\text { POPULAR NAMES }\end{array}$ & SH & MT & BR & GA & PO & LG & BU & DO & BN & MW & FR & MX & CA \\
\hline $\begin{array}{l}\text { Rubiaceae } \\
\text { Psychotria ipecacuanha } \\
\text { (Brot.) Stockes./ } \\
\text { Ipecacuanha, poaia }\end{array}$ & $x^{*}$ & $x$ & $x$ & & $x$ & $x$ & $x$ & $x$ & & $x$ & $x$ & & \\
\hline $\begin{array}{l}\text { Amaranthaceae } \\
\text { Gomphrena officinalis } \\
\text { Mart./ Paratudo }\end{array}$ & $x^{*}$ & $x$ & & $x$ & & & $x$ & & $x$ & & & & \\
\hline $\begin{array}{l}\text { Aristolochiaceae } \\
\text { Aristolochia cymbifera } \\
\text { Mart. \& Zucc./ Jarrinha, } \\
\text { Cassaú }\end{array}$ & $x$ & $x$ & $x$ & & & $x$ & & $x$ & & & & & \\
\hline
\end{tabular}




\begin{tabular}{llllllllllllll}
\hline FAMILY AND SCIENTIFIC/ & SH & MT & BR & GA & PO & LG & BU & DO & BN & MW & FR & MX & CA
\end{tabular}
POPULAR NAMES

\section{Leguminosae}

Anadenanthera colubrina

(Vell.) Brenan.; A. rigida

Benth./ Angico

\section{Leguminosae}

Senna occidentalis L./ $\quad x \quad x \quad x \quad x \quad x$

Fedegoso

Leguminosae

Stryphnodendron

adstringens (Mart.)

Coville./ Barbatimão

\section{Aquifoliaceae}

Ilex paraguariensis A. St.- $\quad \mathrm{x} \quad \mathrm{x} \quad \mathrm{x} \quad \mathrm{x}$

Hil./ Mate

\section{Asteraceae}

Lychnophora pinaster

Mart., L. affinis Gardner/

Arnica

\section{Myrtaceae}

Eugenia dysenterica DC./ $\quad x \quad x \quad x \quad x$

Cagaiteira

\section{Rubiaceae}

Remijia ferruginea (A.St- $\quad x^{*} \quad x^{*} \quad x \quad x$

Hil.) DC / Quina

mineira, quina da serra

\section{Vochysiaceae}

Qualea grandiflora Mart./ $\quad x \quad$ x $\quad$ x $\quad$ x

Pau Terra

\section{Anacardiaceae}

Schinus terebinthifolius $\quad \mathrm{x} \quad \mathrm{x}^{*} \mathrm{x}$

Raddi / Aroeira

\section{Annonaceae}

Annona crassiflora Mart./ $\quad x \quad$ x $\quad$ x

Araticum

\section{Asteraceae}

Baccharis trimera (Less.) $\quad \mathrm{x} \quad \mathrm{x}^{*}$

DC./ Carqueja amarga

\section{Bignoniaceae}

Tabebuia impetiginosa $\quad x \quad x \quad x$

(Mart. ex DC.) Standl./

Ipê-Roxo

\section{Capparaceae}

Colicodendron yco Mart/

icó 


\begin{tabular}{llllllllllllll}
\hline $\begin{array}{l}\text { FAMILY AND SCIENTIFIC/ } \\
\text { POPULAR NAMES }\end{array}$ & SH & MT & BR & GA & PO & LG & BU & DO & BN & MW & FR & MX & CA \\
\hline
\end{tabular}

Euphorbiaceae
Croton fulvus Mart., C.
campestris A. St.-Hil./

\section{Euphorbiaceae}

Croton perdicipes A. St.- $\quad x^{*} \quad x^{*} \quad x$

Hil./ Pé de perdiz,

alcanfora

Lamiaceae
Hyptis fruticosa Salzm. ex $\quad x \quad x^{*} \quad x$
Benth., H. spicata Poit., H.
fasciculata Benth./
Hortelã do campo

\section{Lecythidaceae}

Lecythis ollaria Loefl./

$\mathrm{x}-\mathrm{x}$

Sucupira, sapucaia

\section{Leguminosae}

Bauhinia forficata Link/ $x \quad x \quad x$

Unha de vaca, unha-de-

boi

Leguminosae

Copaifera spp. / copaíba $\quad$ x $\quad$ x $\quad$ x

\section{Malpighiaceae}

Byrsonima verbascifolia $\quad \mathrm{x} \quad \mathrm{x} \quad \mathrm{x}$

(L.) DC./ Murici, guiné

\section{Simaroubaceae}

Simarouba versicolor St. $\quad x^{*} \quad x^{*} \quad x$

Hil./ Paraíba

\section{Solanaceae}

Solanum lycocarpum A. $\quad \mathrm{x} \quad \mathrm{x}$

St.-Hil./ Lobeira

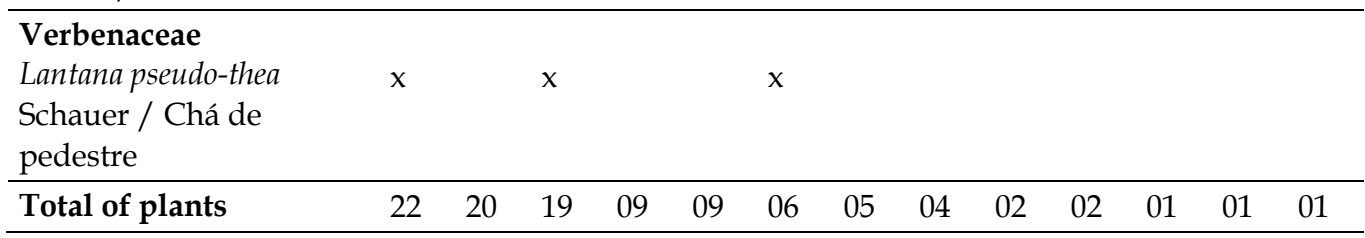

$\mathrm{SH}=$ Saint-Hilaire, $\mathrm{MT}=$ Martius, $\mathrm{BR}=$ Burton, $\mathrm{GA}=$ Gardner, $\mathrm{PO}=$ Pohl, $\mathrm{LG}=$ Langsdorff,

$\mathrm{BU}=$ Burmeister, $\mathrm{DO}=\mathrm{D}^{\prime}$ Orbigny, $\mathrm{BN}=$ Bunbury, $\mathrm{MW}=$ Mawe, $\mathrm{FR}=$ Freireyss, $\mathrm{MX}=$ Maximilian

Neuwied, CA=Castelnau

* Books specific about medicinal plants: Plantes usuelles des Brasiliens and Systema Materiae Medicae Vegetabilis Brasiliensis

Table 1. The native medicinal species registered by three or more European naturalists along the Royal Road, Minas Gerais, Brazil. 
The naturalists A. de Saint-Hilaire (22 species), K. von Martius (20) and R. Burton (19) cited a larger number of plants along the Royal Road, Minas Gerais. Their travel books described the species Psychotria ipecacuanha (Rubiaceae), Aristolochia cymbefera (Aristolochiaceae), Senna occidentalis (Leguminosae), Stryphnodendron adstringens (Leguminosae), Ilex paraguariensis (Aquifoliaceae), Eugenia dysenterica (Myrtaceae), Remijia ferruginea (Rubiaceae), Schinus terebinthifolius (Anacardiaceae), Croton fulvus and C. campestris (Euphorbiaceae) and Copaifera spp. (Leguminosae). The most cited species included Psychotria ipecacuanha (Rubiaceae), Gomphrena officinalis (Amaranthaceae) and Remijia ferruginea (Rubiaceae), which were described by Saint-Hilaire in his book on the use of medicinal plants, "Plantes Usuelles des Brasiliens" (Usual Plants from Brazilians; Saint-Hilaire, 1824a). Similarly, the species Schinus terebinthifolius (Anacardiaceae), Baccharis trimera (Asteraceae), Colicodendron yco (Capparaceae), Croton perdicipes (Euphorbiaceae) and Hyptis spp. (Lamiaceae) were described by von Martius in his book "Systema Materiae Medicae Vegetabilis Brasiliensis" (1843). The utility of Remijia ferruginea (Rubiaceae), Croton perdicipes (Euphorbiaceae) and Simaruba versicolor (Simarubaceae) was included in both books, which indicates the medicinal importance of these species at that time.

Naturalists cited the species Rubiaceae Psychotria ipecacuanha (Brot.) Stokes, then called Cephaelis ipecacuanha (Brot.) A. Rich. (ipecacuanha or poaya), most frequently. Its use was described by Saint-Hilaire, von Martius, Burton, Pohl, Langsdorff, Burmeister, D'Orbgni, Mawe and Freyress. This species originated in the Atlantic Forest and has been used for centuries by Native Americans as an anti-diarrheal and emetic. The roots of this species were extremely valued by Brazilians at that time, when approximately four tons were transported annually from Rio de Janeiro to Portugal. The use of this plant and its exploration have been widely observed by Saint-Hilaire, von Martius, Burton, Pohl, Langsdorff, Burmeister, D'Orbgni, Mawe and Freireyss. All of the naturalists were concerned about the possible extinction of this species. The extensive exploitation of this plant since the eighteenth century has led to its rarity and endangered status, as declared by the Environment Agency of Brazil (Oliveira \& Martins, 2002). Traditional uses of P. ipecacuanha as an emetic and anti-diarrheal have been confirmed by several pharmacological studies, which illustrated that their medicinal actions are due to the presence of the alkaloids emetine and cephaeline in the plant. These substances act specifically on Entamoeba, parasites that cause diarrhea, which were prevalent and often fatal at that time. Because of its importance in medicine, this species is included in the official lists of the pharmacopoeia of many countries and of the World Health Organization (WHO, 2007).

Table 1 presents the other frequently mentioned species that were registered by five naturalists in Minas Gerais: Gomphrena officinalis Mart. (Amaranthaceae, paratudo), Aristolochia cymbifera Mart. \& Zucc. (Aristolochiaceae, jarrinha, cassaú) and the Leguminosae Anadenanthera colubrina (Vell) Benth (Angico), Senna occidentalis L. (fedegoso) and Stryphnodendron adstringens (Mart.) Coville (barbatimão). From these, G. officinalis was registered by Saint-Hilaire in his book "Plantes Usuelles des Brasiliens" (Saint-Hilaire, 1824a). Senna officinalis and Stryphnodendron adstringens were recorded by the same naturalists (Saint-Hilaire, von Martius, Burton, Pohl and Langsdorff), indicating a consistent cataloging of the use of these plants.

The species G. officinalis, Aristolochia spp., R. ferruginea, B. trimera, B. forficata and S. versicolor were used to treat fever and malaria. At that time, several plants were used by the population of Brazil to treat fevers, which were a common health problem. The intermittent fevers were the most dreaded and exhibited symptoms typical of malaria, a disease caused by the Plasmodium parasite, which can lead to death. The search for the malaria cure began 
in the seventeenth century, when the Spaniards identified the bark of the Cinchona genus, especially the Peruvian native C. succiruba, which was used by Native Americans to treat fevers. These plants were known as the popular "quina". They produce quinine, a potent drug against malaria that is still used to treat cases of chemotherapy-resistant parasites. Cinchona species are not found in Brazil, but the name of quina is ascribed to many other medicinal plants. Naturalists, particularly Saint-Hilaire, mentioned several of these plants. He regarded the bark of Quina-mineira or Quina-da-serra (Remijia ferruginea (A. St.Hil.) DC., Rubiaceae) to be a very effective treatment for fevers, similar to the uses of Carqueja (Baccharis trimera (Less.) DC., Asteraceae) and the Unha de vaca ou Pata-de-vaca (Bauhinia forficata Link, Fabaceae). Today, only R.ferruginea has been evaluated for its antimalarial potential, which has displayed some activity, demonstrating the importance of traditional information. Indeed, malaria remains one of the most devastating diseases in the world that affects millions of people annually in the tropics and subtropics. The other species mentioned by St. Hilaire should be tested, especially those belonging to the family Rubiaceae, the same botanical family as Cinchona spp.

Saint-Hilaire described a plant originating in South America, the mate, Ilex paraguariensis A. St.-Hil. The infusion of the plant was already used by American Indians before the arrival of the Europeans, and its use was found in Minas Gerais. This plant is currently used in Argentina, Paraguay, Uruguay and southern Brazil and is one of Southern Brazil's major exports. The I. paraguariensis is promising due to the high caffeine content and its use as a digestive. Studies have illustrated the beneficial action of the tea plant as a choleretic, thus confirming its traditional use.

The remedies of the plants described by the naturalists were rapidly incorporated into medical practice. By 1854, the book "Systema Materiae Medicae Vegetabilis Brasiliensis" had been translated into Portuguese (Martius, 1954). The Danish Doctor Theodore Langgaard (1813-1883) came to Brazil in 1842, and in 1846, he published the "Dictionary of Domestic and Popular Medicine" (Langgaard, 1865). This book came in two editions, with nearly 1,500 pages, and described many native Brazilian medicinal plants. Chernoviz (18121881) was born in Poland (Lukov) and was forced to emigrate as a young medical student at Warsaw University. He continued his studies in France, and in 1837, he obtained his doctorate in medicine from the University of Montpellier. In December of that year, his diploma was recognized by the medical school of Rio de Janeiro, and he was accepted into the Imperial Academy of Medicine. He wrote several seminal books, including "Dicionário e Guia Médico" and "Manual de Medicina Popular", that were widely used by doctors and pharmacists until the publication of the Brazilian Official Pharmacopoeia in 1929. Recipes, that included several species are registered in this book as Gomphrena officinalis Mart, employed as digestive promoters, anti-diarrheal agents, fever reducers, Simarouba versicolor A. St.-Hil., used to kill lice in humans and in animals, and Croton spp., used as a sudorific and a stimulant, as shown in Table 2 (Chernoviz, 1996; Guimarães, 2005).

\section{The contributions of European naturalists in valuing Brazilian biodiversity}

The use of medicinal plants and herbal medicine is expanding worldwide. The current demand for complementary and alternative medicine may be in part due to the dissatisfaction with conventional medicine or the high cost of manufactured drugs. Their popularity has prompted pharmaceutical companies to invest in research and patenting of new bioactive compounds or extracts standardized for the preparation of new products. Brazil has 
enormous potential for the discovery of new bioactive substances, home to one of the most diverse floras on the planet and to traditional medicine practiced by the Amerindians, which has been superficially studied. The World Health Organization, while recognizing the traditional use of plants for therapy, stresses the need for their validation. These studies would include the validation of the efficacy and safety of the plant, which are essential requirements for the employment of any medicine. These products, referred to as herbal medicine, must be well manufactured and be widely available at a low cost. In Europe, herbal medicines have been used for many decades, and most of them are standardized and prescribed by doctors. China and India have considerable experience in using plants as medicine, despite the fact that their efficacy has not been tested by pharmacological assays.

\begin{tabular}{|c|c|c|c|}
\hline Family/Scientific name & Vernacular name & $\begin{array}{l}\text { Popular uses / } \\
\text { Indications }\end{array}$ & $\begin{array}{l}\text { Studies related to the } \\
\text { popular use }\end{array}$ \\
\hline $\begin{array}{l}\text { Anacardiaceae } \\
\text { Schinus mucronulatus } \\
\text { Mart. }\end{array}$ & Aroeira, Corneiba & ulcers & Lucena et al., 2006 \\
\hline $\begin{array}{l}\text { Apiaceae } \\
\text { Eryngium lingua tucani } \\
\text { Mart. }\end{array}$ & Língua de Tucano & $\begin{array}{l}\text { diuretic, } \\
\text { inflammations }\end{array}$ & none \\
\hline $\begin{array}{l}\text { Apocynaceae } \\
\text { Plumeria drastica Mart. }\end{array}$ & Tiborna & $\begin{array}{l}\text { intermittent fevers, } \\
\text { jaundice }\end{array}$ & none \\
\hline $\begin{array}{l}\text { Asteraceae } \\
\text { Mikania officinalis Mart. }\end{array}$ & Coração de Jesus & $\begin{array}{l}\text { tonic, stimulant, } \\
\text { fevers }\end{array}$ & none \\
\hline $\begin{array}{l}\text { Bignoniaceae } \\
\text { Zeyheria montana Mart. }\end{array}$ & Bolsa de pastor & $\begin{array}{l}\text { against diseases of the } \\
\text { skin }\end{array}$ & none \\
\hline $\begin{array}{l}\text { Clusiaceae } \\
\text { Kielmeyera speciosa A. St. } \\
\text { Hil. }\end{array}$ & Malva do campo & bath emollients & none \\
\hline $\begin{array}{l}\text { Combretaceae } \\
\text { Terminalia argentea Mart. }\end{array}$ & $\begin{array}{l}\text { Caxaporra do } \\
\text { gentio }\end{array}$ & purgative & none \\
\hline $\begin{array}{l}\text { Convolvulaceae } \\
\text { Piptostegia pisonis Mart. }\end{array}$ & Ipú & purgative & none \\
\hline $\begin{array}{l}\text { Cucurbitaceae } \\
\text { Trianosperma ficifolia Mart }\end{array}$ & $\begin{array}{l}\text { Abóbora do mato, } \\
\text { Tayuyá, }\end{array}$ & $\begin{array}{l}\text { hidropsy, } \\
\text { amenorrhea, ulcers }\end{array}$ & none \\
\hline $\begin{array}{l}\text { Cayaponia cabocla (Vell.) } \\
\text { Martius }\end{array}$ & $\begin{array}{l}\text { Purga de gentio, } \\
\text { caboclo }\end{array}$ & purgative, depurative & none \\
\hline $\begin{array}{l}\text { Dilleniaceae } \\
\text { Davilla elliptica A. St. Hil. }\end{array}$ & Sambaibinha & $\begin{array}{l}\text { astringent, } \\
\text { inflammations }\end{array}$ & $\begin{array}{l}\text { Azevedo et al., 2007; } \\
\text { Kushima et al., } 2009\end{array}$ \\
\hline Curatella cambaiba St. Hil. & Sambaiba & astringent, ulcers & $\begin{array}{l}\text { Hiruma-Lima et al., } \\
2009\end{array}$ \\
\hline
\end{tabular}




\begin{tabular}{|c|c|c|c|}
\hline Family/Scientific name & Vernacular name & $\begin{array}{l}\text { Popular uses / } \\
\text { Indications }\end{array}$ & $\begin{array}{l}\text { Studies related to the } \\
\text { popular use }\end{array}$ \\
\hline \multicolumn{4}{|l|}{ Euphorbiaceae } \\
\hline Croton perdicipes A. St. Hil. & Pé de perdiz & $\begin{array}{l}\text { sudorific, wound } \\
\text { healing }\end{array}$ & none \\
\hline $\begin{array}{l}\text { Croton campestris A. St. } \\
\text { Hil. }\end{array}$ & Velame do campo & purgative & none \\
\hline \multicolumn{4}{|l|}{ Fabaceae } \\
\hline Cassia cathartica Mart. & Sene do campo & $\begin{array}{l}\text { diuretics, tonic, } \\
\text { purgative }\end{array}$ & none \\
\hline Acacia jurema Mart. & Jurema & ulcers & none \\
\hline $\begin{array}{l}\text { Gentianaceae } \\
\text { Lisianthus amplissimus } \\
\text { Mart. }\end{array}$ & Genciana brasileira & febrifuge & Carvalho et al., 1991 \\
\hline $\begin{array}{l}\text { Loganiaceae } \\
\text { Strychnos pseudoquina St. } \\
\text { Hil. }\end{array}$ & Quina do campo & intermittent fevers & $\begin{array}{l}\text { Andrade-Neto et al., } \\
2003\end{array}$ \\
\hline $\begin{array}{l}\text { Malvaceae } \\
\text { Helicteres sacarolha A. St. } \\
\text { Hil. } \\
\text { Paronia diuretica A St.Hil }\end{array}$ & Sacarolha & $\begin{array}{l}\text { emollient, } \\
\text { inflammations }\end{array}$ & none \\
\hline Pavonia aturetica A. St. Hil. & Malva diuretıca & emollient, diuretics & none \\
\hline $\begin{array}{l}\text { Meliaceae } \\
\text { Moschoxylon catharticum } \\
\text { Mart. }\end{array}$ & $\begin{array}{l}\text { Marinheiro de folha } \\
\text { miúda }\end{array}$ & intermittent fevers & none \\
\hline $\begin{array}{l}\text { Moraceae } \\
\text { Dorstenia opifera Mart. }\end{array}$ & $\begin{array}{l}\text { Caapiá, } \\
\text { Contraherva, }\end{array}$ & fevers, emmenagogue & none \\
\hline $\begin{array}{l}\text { Rubiaceae } \\
\text { Cinchona ferruginea A. St. } \\
\text { Hil. }\end{array}$ & Quina da serra & intermittent fevers & $\begin{array}{l}\text { Andrade-Neto et al., } \\
2003\end{array}$ \\
\hline $\begin{array}{l}\text { Rutaceae } \\
\text { Ticorea febrifuga St. Hil. }\end{array}$ & Três folhas brancas & intermittent fevers & none \\
\hline $\begin{array}{l}\text { Simaroubaceae } \\
\text { Simaba ferruginea A. St. } \\
\text { Hil. }\end{array}$ & Calunga & $\begin{array}{l}\text { dispepsy, intermittent } \\
\text { fevers }\end{array}$ & none \\
\hline $\begin{array}{l}\text { Simaroruba versicolor St. } \\
\text { Hil. }\end{array}$ & Parahyba & kills lice & Coelho et al., 2006 \\
\hline $\begin{array}{l}\text { Verbenaceae } \\
\text { Lantana pseudothea St. Hil. }\end{array}$ & Chá de pedestre & stimulant & none \\
\hline $\begin{array}{l}\text { Violaceae } \\
\text { Anchietea salutaris A. St. } \\
\text { Hil. }\end{array}$ & Piragaia & purgative & none \\
\hline
\end{tabular}

Table 2. The medicinal uses of the species discovered and described by A. de Saint-Hilaire and von Martius and published by Chernovicz in 1869 (Chernovicz, 1996). 
Very few plants mentioned by the naturalists have been subjected to pharmacological analysis, but all of the species that have been evaluated have shown promising results. Activities have been confirmed for the çambaibinha (Davilla elliptica A.St.-Hil.) as anti-inflammatory, pinhão de purga (Jatropha curcas L.) as a purgative, the quina (Strychnos pseudoquina A.St.- Hil., Remijia ferruginea DC.) as anti-malarial, capeba (Piper umbellatum L.) and the casca d'anta (Drimys winteri JRForst.) as analgesic. These results confirm the importance of traditional information obtained from the naturalists for developing new products.

In Brazil, many medicinal plants have become important in conventional medicine, as indicated by their inclusion in the $1^{\text {st }}$ edition of the Brazilian Pharmacopoeia (Brandão et al., 2006b; Brandão et al., 2008a). The Brazilian Pharmacopoeia (FBRAS) has five editions, published in 1926, 1959, 1977, 1996 and 2010. Each drug is described in the pharmacopoeia in monographic form. Nine species described by Saint-Hilaire were included in an edition of FBRAS, attesting not only to their importance in traditional medicine practiced by the population but also to the doctors and pharmacists of the time. Saint-Hilaire also described the species Mate (Ilex paraguariensis A. St.-Hil.), quina-de-mendanha ou quina-do-campo (Strychnos pseudoquina A. St.- Hil.), paineira (Chorisia speciosa St-Hil.), the douradinha (Waltheria communis A.St.-Hil.), butua (Chondrodendron platyphylum (A. St.- Hil.) Miers), the quina-deremijio (Remijia ferruginea (A.St.-Hil.) DC. (Cinchona ferruginea A.St.-Hil.), tinguaciba (Zanthoxylum tingoassuiba A. St.- Hil.), capitão-do-mato ou chá-de-pedestre (Lantana or Lippia pseudothea Schauer A. St-Hil.) and cipo suma or piraguaia (Anchietea pyrifolia (A. St-Hil.), which were published in the $1^{\text {st }}$ edition of FBRAS. The number of monographs allotted to the native species of Brazil in the 2nd edition of FBRAS, published in 1959, was reduced dramatically. While only four monographs, describing the species Paullinia cupana, Sapindaceae, guaraná; Passiflora alata, Passifloraceae, maracujá; Psycothria ipecacuanha, Rubiaceae, ipeca; Pilocarpus jaborandi, Rutaceae, jaborandi, remained in the third edition, that number is increased in the 4 th and 5 th editions. The reduction in the number of monographs for native products of FBRAS was indicative of the transformations in Brazilian society from 1950 to 1970. During this time, the Brazilian industry reorganized, and "consumer society" underwent a major cultural realignment. In the 1970s, for example, the pharmacy business had already lost the importance it once held previously because the pharmaceutical industry came to completely dominate the drug market. This period was also characterized by intense fighting and a repression of mysticism, including the traditional use of plants. All of these processes have contributed to a lack of interest in medicinal plants, a situation that was reversed from the 1980s by the influence of the WHO (Manhã et al., 2008).

For decades, several native medicinal species have been used by pharmaceutical companies in Brazil to create commercial products. These companies are represented by small laboratories that evaluate their products on the basis of traditional formulas. Species described by von Martius and in FBRAS were used in manufacturing medicines, such as Velame (Croton spp.), the Quina-de-mendanha (S. pseudoquina), Douradinha (W. douradinha), Butua (C. platyphyllum) and Cipó-suma (A. pyrifolia). However, these preparations often did not meet the minimal standards of the WHO recommendations for products for traditional use (Brandão et al., 2010). Since 1995, the Governmental Health Agencies of Brazil, following the recommendations of the WHO (WHO, 2002), established a series of regulations to improve the quality of commercial herbal products (Carvalho et al., 2008). Companies have made some efforts to develop standardized phyto-medicines from native species while also assessing their quality, safety and efficacy. Acheflan ${ }^{\circledR}$ is a rare example. It is produced with essential oils obtained from Cordia verbenaceae, a native species used in Brazilian traditional 
medicine to treat inflammations (Calixto, 2005). More exotic and imported species, rather than native species, are implemented in the pharmaceutical industry. These species, including Foeniculum vulgaris, Panax ginseng, Matricharia recutita, Ginkgo biloba, Hypericum perforatum, Melissa officinalis, Aloe barbadensis, Valeriana officinalis and Zingiber officinalis, are used in the preparation of several products by industries in Minas Gerais, whereas no products incorporate native Brazilian species. In fact, there is a paucity of knowledge, among both the population and within the scientific community, regarding the pharmacological properties of native Brazilian plants. Table 3 presents ten medicinal species described by von Martius in 19th century and in the $1^{\text {st }}$ edition of Brazilian Official Pharmacopoeia. Despite their importance as traditional Brazilian therapies, only the Leguminosae Erythrina mulungu has been incorporated into medicine by national industries (Brandão et al., 2010).

\begin{tabular}{|c|c|c|c|}
\hline Family/ Species & Vernacular name & part & $\begin{array}{l}\text { Current } \\
\text { commercial } \\
\text { uses }\end{array}$ \\
\hline $\begin{array}{l}\text { Arecaceae/ Copernicia cerifera (Arruda) } \\
\text { Mart }\end{array}$ & $\begin{array}{l}\text { Carnaubeira / Carnauba / } \\
\text { Caranda }\end{array}$ & Roots & $\begin{array}{l}\text { Wax in the } \\
\text { automobile } \\
\text { industry }\end{array}$ \\
\hline $\begin{array}{l}\text { Aristolochiaceae / Aristolochia cymbifera } \\
\text { Mart. \& Zucc. }\end{array}$ & $\begin{array}{l}\text { Cassau / Jarrinha / Cipo } \\
\text { mil homens / Papo de } \\
\text { peru/ Angelicó }\end{array}$ & Roots & none \\
\hline $\begin{array}{l}\text { Bignoniaceae/ Anemopaegma mirandum } \\
\text { (Cham.) Mart. ex DC }\end{array}$ & Catuaba / Catuiba & Roots & none \\
\hline $\begin{array}{l}\text { Commelinaceae/ Tradescantia diuretica } \\
\text { Mart. }\end{array}$ & Trapoeraba & Leaves & none \\
\hline $\begin{array}{l}\text { Fabaceae/ Copaifera oblongifolia (Mart.) } \\
\text { Kuntze }\end{array}$ & Balsamo de copaiba & Balsam & none \\
\hline $\begin{array}{l}\text { Leguminosae/ Erythrina mulungu } \\
\text { Mart.ex Benth }\end{array}$ & $\begin{array}{l}\text { Mulungu / Murungu/ } \\
\text { Sapatinho de judeu/Bico de } \\
\text { papagaio }\end{array}$ & Wood & medicine \\
\hline $\begin{array}{l}\text { Fabaceae/Stryphnodendron adstringens } \\
\text { (Mart.)Coville }\end{array}$ & $\begin{array}{l}\text { Barbatimao / Barba de } \\
\text { timan / Uabatimo }\end{array}$ & Rind & none \\
\hline $\begin{array}{l}\text { Krameriaceae/ Krameria argentea Mart. } \\
\text { ex Spreng. }\end{array}$ & Ratania / Ratania do Para & Roots & none \\
\hline $\begin{array}{l}\text { Monimiaceae/ Siparuna apiosyce (Mart. } \\
\text { Ex Tul.) A. DC }\end{array}$ & $\begin{array}{l}\text { Limoeiro bravo / Limoeiro } \\
\text { do mato / Negra mina }\end{array}$ & Leaves & none \\
\hline $\begin{array}{l}\text { Sapotaceae/ Chrysophyllum gonocarpum } \\
\text { (Mart.\& Eichler ex Miq.) Engler }\end{array}$ & $\begin{array}{l}\text { Monesia / Buranhem / } \\
\text { Guaranhem / Casca doce }\end{array}$ & Wood & none \\
\hline
\end{tabular}

Table 3. The current commercial uses of the species described by von Martius and the $1^{\text {st }}$ edition of the Brazilian Official Pharmacopoeia (1926).

The development of commercial products from biodiverse plants is considered to be one of the most important strategies for conserving native vegetation biomes, particularly in developing countries (Li \& Vederas, 2009; Nepstadt et al., 2009; Nogueira et al., 2010). Given this situation, investment in the research and development of products from the Brazilian 
native flora is imperative. Despite the complexity and richness of the flora, Brazil merely supplies raw botanical material to the international pharmaceutical market. The alphabisabolol taken from Candeia wood (Eremanthus erytropappa), the rutine obtained from Favela fruits (Dimorphandra mollis), the ipê-roxo bark (Tabebuia avellanedae) and the Copaíba balsam (Copaifera spp.) are natural products obtained from Brazilian native species that are almost exclusively used by international pharmaceutical corporations. The records kept by the visiting naturalists illustrate valuable tools for the development of new commercial products derived from native plant resources. They describe the primary uses of plants because the information was collected at a time when the vegetation was preserved, and traditional medicines incorporated native species almost exclusively. In contrast, Brazilian native plants, particularly the Amerindian, have been forgotten and are used infrequently. Efforts must be taken to protect them and promote a better use for them. The data recorded by the European naturalists are a rich source of information for these efforts.

\section{Conclusion}

The Englishman Richard Burton expressed his admiration for the richness and potential of biodiversity in the region of the São Francisco River in Minas Gerais as follows:

"The hope, and to a certain extent the vines, will flourish. Among the cereals it produces a wealth of maize and rice whilst barley, rye, and probably wheat will succeed in the Geraes. Most of the fruits and vegetables that belong to the subtropical and temperate regions may be introduced. A sugar plantation last three years, although the cane most inefficient treated. Coffee grows admirably; tea, congonha (or mate) and guarana (Paullinia sorbillis) much appreciated in northwestern Brazil, will succeeded in low, hot and humid spots. The tobacco is one of the best in the Empire: sarsaparilla and the cochineal cactus, aloes and vanilla grow wild. Lumber trade is susceptible of a vast development; the Aroeira, the Brauna, the Candea, The Peroba, the Canella, and the fine hard-woods of the Brazil generally, await exploration. Oil-plants and tannins bark, bast and fibers, drugs and gums, as the Jatahy-copal, the Balsam of Peru, The Copaiba and the Asafoetida, are yielded in abundance, and the same way be said of beeswax and the Carnaúba wax, which is converted into candles in Rio de Janeiro. The dyes are abundant, from indigo to the Pau Amarello, and of cabinets woods a long list is headed by the Jacaranda and the Brazilian cedar. In the presence of such vast and unexploited wealth awaiting the distressed classes of Europe we way exclaim with Goethe: "Who says there is nothing for the poor and the vile save poverty and crime?"

Richard Francis Burton The Highlands of Brazil, 1869

Naturalists often discuss their admiration for the greatness and richness of Brazilian biodiversity and its potential. The conservation of biodiversity and its associated traditional knowledge has become a priority for the overall development of several countries. In Brazil, promoting better use of biodiversity is imperative due to the intense process of genetic erosion that has affected most of the native vegetation. Only $7 \%$ of the Atlantic Forest is preserved, and the Cerrado and Caatinga are gradually being replaced by monocultures of eucalyptus, sugarcane, soybeans and livestock. Currently, the native vegetation of Minas Gerais faces the greatest threat from major international mining companies, such as Vale (CVRD) and AngloGold Ashanti, which plan to expand their activities into conserved and biodiverse areas. Therefore, the plants originally documented by naturalists in Minas Gerais run the risk of extinction. Better efforts are necessary to protect this heritage and to promote it's better use. 


\section{Acknowledgements}

This work was funded by research grants and fellowships from the Fundação de Amparo a Pesquisa de Minas Gerais (FAPEMIG) and Conselho de Desenvolvimento Científico e Tecnológico (CNPq) - Edital REFLORA 563563/2010-9.

\section{References}

Andrade-Neto, V.F.; Brandão, M.G.L.; Stehmann, J.R.; Oliveira, L.A. \& Krettli, A.U. (2003). Antimalarial activity of Cinchona-like plants used to treat fever and malaria in Brazil. Journal of Ethnopharmacology, Vol.87, No.2-3, (August 2003 ), pp. 253-256, ISSN 0378-8741

Azevedo, A.O.; Campos, J.J.; Galdino, G.S.; Braga, F.C.; Duarte, I.D. \& Perez, A.C. (2007). Antinociceptive effect from Davilla elliptica hydroalcoholic extract. Journal of Ethnopharmacology, Vol.113, No.2, (September 2007), pp. 354-356, ISSN 0378-8741

Brandão, M.G.L.; Acúrcio, F.A.; Montemor, R.L.M. \& Marlière, L.D.P. (2006a). Complementary/Alternative Medicine in Latin America: Use of Herbal Remedies among a Brazilian Metropolitan Area Population. Journal of Complementary and Integrative Medicine, Vol.3, No.1, (February 2006), pp. 5 - 10, ISSN 1553-3840

Brandão, M.G.L.; Cosenza, G.P.; Moreira, R.A. \& Monte-Mór, R.L.M. (2006b). Medicinal plants and other botanical products from Brazilian Official Pharmacopoeia. Revista Brasileira de Farmacognosia, Vol.16, No.3, (July/September 2006), pp. 408-420, ISSN 0102-695X

Brandão, M.G.L.; Zanetti, N.N.S.; Oliveira, G.R.R.; Goulart, L.O. \& Monte-Mór, R.L. (2008a). Other medicinal plants and botanical products from the first edition of the Brazilian Official Pharmacopoeia. Revista Brasileira de Farmacognosia, Vol. 18, No.1, (January/March 2008), pp. 127-136, ISSN 0102-695X

Brandão, M.G.L.; Zanetti, N.N.S.; Oliveira, P.; Grael, C.F.; Santos, A.C. \& Montemór, R.L.M. (2008b). Brazilian medicinal plants described by 19th century European naturalists and in Official Pharmacopeia. Journal of Ethnopharmacology, Vol.120, No.2 , (November 2008), pp. 141-148, ISSN 0378-8741

Brandão, M. G. L.; Cosenza, G. P.; Stanislau, A.M. \& Fernandes, G.W. (2010). Influence of Brazilian herbal regulations on the use and conservation of native medicinal plants. Environmental Monitoring and Assessment, v.164, No.1-4 , (May 2010), pp.369 - 377, ISSN 0167-6369

Bunbury, C.J.F. (1981). Viagem de um naturalista inglês ao Rio de Janeiro e Minas Gerais, Itatiaia/EDUSP, ISBN 853-1905-00-1, Belo Horizonte/ São Paulo, Brasil

Burmeister, H. (1958) [1853]. Viagem ao Brasil através das Províncias do Rio de Janeiro e Minas Gerais, Livraria Martins Editora, ISBN 853-1907-87-X, São Paulo, Brasil

Burton, R.,(1976) [1869]. Viagem do Rio de Janeiro a Morro Velho, Itatiaia/EDUSP, ISBN 8531903-82-3, Belo Horizonte/ São Paulo, Brasil

Burton, R. (1977) [1869]. Viagem de Canoa de Sabará ao Oceano Atlântico, Itatiaia/EDUSP, ISBN 853-1904-68-4, Belo Horizonte/São Paulo, Brasil

Calixto, J.B. (2005) Twenty-five years of research on medicinal plants in Latin America. A personal view. Journal of Ethnopharmacology, Vol. 100, No.1-2,(August 2005), pp. 131134, ISSN 0378-8741

Carvalho, L.H.; Brandão, M.G.L.; Santos-Filho, D.; Lopes, J.L.C. \& Krettli, A.U. (1991). Antimalarial activity of crude extracts from Brazilian plants against $P$. falcifarum in 
culture and P. berghei in mice. Brazilian Journal of Medical and Biological Research, Vol.24, pp. 1113-1123, ISSN 0100-879X

Carvalho , C.B.; Balbino, E.E.; Maciel, A. \& Perfeito, J.P.S. (2008). Situação do registro de medicamentos fitoterápicos no Brasil. Revista Brasileira de Farmacognosia, Vol. 18, No. 2, (April/June 2008) 314-319, ISSN 0102-695X

Castelnau, F. (1949) [1850]. Expedição às Regiões Centrais da América do Sul, Coleção Brasiliana 266, Companhia Editora Nacional, São Paulo, Brasil

Chernoviz, P.L.N. (1996). A Grande Farmacopéia Brasileira. Formulário e Guia Médico (19a Edition), Itatiaia, ISBN 853-1900-29-3, Belo Horizonte, Brasil

Coelho, A.; de Paula, J.E. \& Espíndola, L.S. (2006). Insecticidal activity of cerrado plant extracts on Rhodnius milesi Carcavallo, Rocha, Galvão \& Jurberg (Hemiptera: Reduviidae), under laboratory conditions. Neotropica Entomology, Vol. 35, No.1, (January/February 2006), pp. 133-138, ISSN 1519-566X

Dean, W. (1996). With Broadax and Firebrand: The Destruction of the Brazilian Atlantic Forest, University of California Press, ISBN 978-052-0208-86-5, Berkeley, USA

D’Orbigny, A. (1976) [ 1836]. Viagem pitoresca através do Brasil, Itatiaia/EDUSP, ISBN 8531904-34-X, Belo Horizonte/ São Paulo, Brasil

Ferrão, J.E.M. (2004). A aventura das plantas e os descobrimentos portugueses (2a Edition), Instituto de Investigação Científica Tropical, ISBN 978-972-8987-00-8, Lisboa, Portugal

França, C. (1922). Doutor Alexandre Rodrigues Ferreira (1756-1815). História de uma Missão Scientifica no Brasil no século XVIII. Boletim da Sociedade Broteriana, Vol.1, No.2, pp. 1-65, ISSN 0081-0657

Freireyss, G.W. (1982) [1815]. Viagem ao Interior do Brasil, Itatiaia/EDUSP, ISBN 853-1906-725, Belo Horizonte/São Paulo, Brasil

Furtado, J.F. (2005). Barbeiros cirurgiões e médicos na Minas Colonial. Revista do Arquivo Público Mineiro, Ano XLI, (December 2005), pp. 89-105, ISSN 0104-8368

Gardner, G. (1975) [1846]. Viagem ao Interior do Brasil, Itatiaia/EDUSP, ISBN 853-1905-65-6, Belo Horizonte; São Paulo, Brasil

Giulietti, A.M.; Harley, R.M.; Queiroz, L.P.; Wanderley, M.G.L. \& Berg, C.V.D. (2005). Biodiversidade e conservação das plantas no Brasil. Megadiversidade, Vol.1, No.1, (July 2005), pp. 52-61, ISSN 1808-3773

Gomes, L.F. (2002). Erario Mineral, vols 1 and 2, Coleção Mineiriana, Ed. Fiocruz, ISBN 8585930-41-1, Belo Horizonte, Brasil

Guimarães, M.R.C. (2005). Chernoviz e os manuais de medicina popular no Império. História, Ciências, Saúde - Manguinhos, Vol. 12, No.2 (May/August 2005), pp. 501514, ISSN 0104-5970

Hiruma-Lima, C.A.; Rodrigues, C.M.; Kushima, H.; Moraes, T.M.; Lolis, S.F.; Feitosa, S.B.; Magri, L.P.; Soares, F.R.; Cola, M.M.; Andrade, F.D.; Vilegas, W. \& Souza Brito, A.R. (2009). The anti-ulcerogenic effects of Curatella americana L. Journal of Ethnopharmacology, Vol.121, No.3, (January 2009), pp. 425-432, ISSN 0378-8741

Humboldt, A. von (1993). Briefe aus Amerika. 1799-1804, Ulrike Moheit, ISBN 978-305-001940-6, Berlin, Germany

IBAMA. (April 2011). Plantas medicinais ameaçadas de extinção, In: Instituto Brasileiro do Meio Ambiente e dos Recursos Naturais Renováveis- IBAMA, 24/04/2011, Available from http://www.ibama.gov.br/flora/divs/plantasextincao.pdf.

Kushima, H.; Nishijima, C.M.; Rodrigues, C.M.; Rinaldo, D.; Sassá, M.F.; Bauab, T.M.; Stasi, L.C.; Carlos, I.Z.; Brito, A.R.; Vilegas, W. \& Hiruma-Lima, C.A. (2009). Davilla elliptica and Davilla nitida: gastroprotective, anti-inflammatory immunomodulatory 
and anti-Helicobacter pylori action. Journal of Ethnopharmacology, Vol.123, No.3, (June, 2009), pp. 430-438, ISSN 0378-8741

Langaard, T.J.H. (1865). Diccionario de Medicina Domestica e Popular, Ediarado Henrique Laemert, Rio de Janeiro, Brasil

Leite, I.B. (1996). Antropologia da Viagem; escravos e libertos em Minas Gerais no século XIX, Editora da UFMG, ISBN 857-0411-09-X, Belo Horizonte, Brasil

Li, J.W.H. \& Vederas, J.C.(2009). Drug discovery and natural products: end of an era or an endless frontier? Science, Vol. 325, No.5937, (July 2009), pp. 161-165, ISSN 0036-8075

Lucena, P.L.; Ribas-Filho, J.M.; Mazza, M.; Czeczko, N.G.; Dietz, U.A.; Correa Neto, M.A.; Henriques, G.S.; Santos, O.J.; Ceschin, A.P. \& Thiele, E.S. (2006). Evaluation of the aroeira (Schinus terebinthifolia Raddi) in the healing process of surgical incision in the bladder of rats. Acta Cirurgica Brasileira, Vol.21, Suppl 2, (2006), pp.46-51, ISSN 0102-8650

Machado, I.F. \& Figueirôa, S.F.M. (2001). 500 years of mining in Brazil: a brief review. Resources Policy, Vol.27, No.1, (March 2001), pp. 9-19, ISSN 0301-4207

Manhã, E.M.; Silva, M.C.; Alves, M.G.C.; Almeida, M.B. \& Brandão, M.G.L. (2008) PLANT: A bibliographic database about medicinal plants. Revista Brasileira de Farmacognosia, Vol. 18, No.4, (October/ December 2008), pp. 614 - 617, ISSN 0102-695X

Martinelli, L.A.; Joly, A.A.; Nobre, C.A. \& Sparovek, G. (2010). A falsa dicotomia entre a preservação da vegetação natural e a produção agropecuária. Biota Neotropica, Vol. 10, No.4, (October 2010), pp. 323-330, ISSN 1676-0611

Martius, C.F.P. (1843). Systema Materiae Medicae Vegetabilis Brasiliensis. Lipsiae. \& Vindobonae.

Martius, C.F.P. (1854). Systema de Materia Medica Vegetal Brasileira. Typografia Universal de Laemmert: Rio de Janeiro.

Mawe, J. (1978) [1812]. Viagens no interior do Brasil, Itatiaia/EDUSP, Belo Horizonte/São Paulo, Brasil

Medeiros, M.F.T. (2008). Historical Ethnobotany: an approach through historical documents and their implications now days, In: Recent development and case studies in ethnobotany, Albuquerque, U.P. \& Hanzaki, N., pp. 127-142, Brazilian society of ethnobiology and ethnoecology, ISBN 9788577167111, Recife, Pernambuco, Brasil

Michalski, F.; Peres, C.A. \& Lake, I.R. (2008). Deforestation dynamics in a fragmented region of southern Amazonia: evaluation and future scenarios. Environmental Conservation, Vol. 35, No.2 (June 2008), pp. 93-103, ISSN 0376-8929

Moreira, I.C. (2002). O escravo do naturalista- o papel do conhecimento nativo nas viagens científicas do século 19. Ciência Hoje, Vol. 31, No.184, (July 2002), pp. 40-48, ISSN 0101-8515

Nepstad, D.; Soares-Filho, B.S. ; Merry, F. ; Lima, A. ; Moutinho, P. ; Carter, J. ; Bowman, M. ; Cattaneo, M. ; Rodrigues, H. ; Schwartzman, S. ; Macgrath, D.G. ; Stickler, C.M. ; Lubowsky, R. ; Piris-Cabezas, P. ; Rivero, S. ; Alencar, A. ; Almeida, O. \& Stella, O. (2009). The end of deforestation in the Brazilian Amazon. Science, Vol. 326, No.5958, (December 2009), pp. 1350-1351, ISSN 0036-8075

Neuwied, M.W. (1989). Viagem ao Brasil, Itatiaia/EDUSP, ISBN 853-1906-73-3, Belo Horizonte/São Paulo, Brasil

Nogueira, R.C.; Cerqueira, H.F. \& Soares, M.B.P. (2010). Patenting bioactive molecules from biodiversity: the Brazilian experience. Expert opinion in therapeutic patents, Vol. 20, No. 2, (February 2010), pp. 1-13, ISSN 1354-3776

Oliveira, L.O. \& Martins, E.R. (2002). A quantitative assessment of genetic erosion in ipecac (Psychotria ipecacuanha). Genetic Resources and Crop Evolution, Vol.49, No.6, (December 2002), pp.607-617, ISSN 0925-9864 
Pereira, N.A., Jaccoud, R.J.S. \& Mors, W.B. (1996). Triaga Brasílica: renewed interest in a seventeeth-century panacea. Toxicon, Vol. 34, No. 5, (May 1996), pp. 511-516, ISSN 0041-0101

Pisonis, G. 1648. Historiae Naturalis \& Medicae. De Arboribus, Fruticibum \& Herbis Medicinalibus, ac Alimentosfis in Brasilia, Elzevier, Amsterdam, Netherlands

Pohl, J.E. (1976) [1832]. Viagem no interior do Brasil, Itatiaia/EDUSP, ISBN 853-1904-740-9, Belo Horizonte/São Paulo, Brasil

Pohl, J.E. (1827). Plantarum Brasiliae Icones et Descriptions 2vols, Vindobonae, Vienna

Rodrigues, V.E.G. \& Carvalho, D.A. (2007). Levantamento etnobotânico de plantas medicinais no domínio dos cerrados na região do Alto Rio Grande - Minas Gerais. Revista Brasileira de Plantas Medicinais, Vol.9, No.2, (n.d.), pp. 17-35, ISSN 1516-0572

Saint-Hilaire A. (1824a). Plantes Usuelles des Brasiliens, Grimbert Libraire, Paris, France.

Saint-Hilaire A. (1824b). Histoire des Plantes les plus remarquables du Brésil et du Paraguay, Chez A. Berlin, Imprimer Libraire, ISBN 978-116-6791-22-3, Paris, France

Saint-Hilaire, A. (1975a) [1830]. Viagem pelo distrito dos diamantes e litoral do Brasil, Itatiaia/EDUSP, ISBN 853-1906-74-1, Belo Horizonte/São Paulo, Brasil

Saint-Hilaire, A. (1975b) [1830]. Viagem às nascentes do Rio São Francisco, Itatiaia/EDUSP, ISBN 853-1905-84-2, Belo Horizonte/São Paulo, Brasil

Saint-Hilaire, A. (1975c) [1830]. Viagem ao Espírito Santo e Rio Doce, Itatiaia/EDUSP, ISBN 853-1904-98-6, Belo Horizonte/São Paulo, Brasil

Saint-Hilaire, A. (1975d) [1830]. Viagem pelas províncias do Rio de Janeiro e Minas Gerais, Itatiaia/EDUSP, ISBN 853-1901-03-0, Belo Horizonte/São Paulo, Brasil

Santos, A.C.P.; Quinelato, M.; Grael, C.F.F.; Fagg, C.W. \& Brandão, M.G.L. (2011). Current use of native medicinal species recorded by European Naturalists in the $19^{\text {th }}$ century along the Royal Road, Minas Gerais, Brazil. Bioremediation, Biodiversity \& Bioavailability, Vol. 5, No. 1 (special issue), (October, 2011), pp. 113-116, ISSN 1749-0596

Sawyer, D. (2008). Climate change, biofuels and eco-social impacts in the Brazilian Amazon and Cerrado. Philosophical Transaction of the Royal Society B: Biological Sciences, Vol. 363, No.1498, (May 2008), pp. 1747-1752, ISSN 0962-8436

Schmeda-Hirschmann, G. \& Arias, A.R. (1990). A survey of medicinal plants of Minas Gerais, Brazil. Journal of Ethnopharmacology, Vol., 29, No.2,(May 1990), pp.159-172, ISSN 0378-8741

Silva, D.B. (1997a). Diários de Langsdorff - Vol.1, Editora da FIOCRUZ, ISBN 858-6515-02-7, Rio de Janeiro, Brasil

Silva, D.B. (1997b). Diários de Langsdorff - Vol.2, Editora da FIOCRUZ, ISBN 858-6515-03-5, Rio de Janeiro, Brasil

Silva, D.B. (1998). Diários de Langsdorff - Vol.3, Editora da FIOCRUZ, ISBN 858-6515-047-3, Rio de Janeiro, Brasil

Spix, J.B. \& Martius, C.F.P. (1981) [1823]. Viagem pelo Brasil (1817-1820) 3 vols, Itatiaia/EDUSP, ISBN 853-1905-69-9, Belo Horizonte/ São Paulo, Brasil

Stehmann, J.R. \& Brandão, M.G.L. (1995). Medicinal plants from Lavras Novas, Minas Gerais, Brazil. Fitoterapia, Vol. 66, (n.d.), pp. 515-520, ISSN 0367-326X

Wolters, B. (1992). Jarhtausend vor Kolumbus: Indianische kulturpflanzen und Arzneidrogen. Deutsche Apotheker Zeitung, Vol. 40, (n.d.), pp.1-10, ISSN 0011-9857

World Health Organization - WHO (2002). Traditional Medicine Strategy 2002-2005, WHO, Geneva

World Health Organization -WHO (2007). Selected Monographs for Medicinal Plants - Vol.3, WHO, ISBN 978-9241-547-02-4, Geneva 


\title{
The Medicinal Value of Biodiversity: New Hits to Fight Cancer
}

\author{
Giselle Z. Justo1, Ana C. S. Souza², Ângelo de Fátima³, \\ Matheus F. F. Pedrosa ${ }^{4}$, Carmen V. Ferreira ${ }^{5}$ and Hugo A. O. Rocha ${ }^{4}$ \\ ${ }^{1}$ Universidade Federal de São Paulo \\ 2 Universidade Federal do $A B C$ \\ ${ }^{3}$ Universidade Federal de Minas Gerais \\ 4 Universidade Federal do Rio Grande do Norte \\ 5 Universidade Estadual de Campinas \\ Brasil
}

\section{Introduction}

Natural products are produced by a wide range of different organisms. Microorganisms, plants, marine species, and animals employ such compounds for several purposes such as building blocks, coenzymes and cofactors, host-defense against microbial infection and predators, protection of ecological niches, communication between and within species, pigments, cellular signaling, gene expression, and homeostasis maintenance. Currently, many key therapeutic classes of drugs in use are derived from natural products, such as the antimalarial drug artemisinin, several anticancer agents, the lipid-lowering statins and immunosuppressors used to prevent the rejection of tissue grafts (Harvey, 2010).

Since ancient times, natural products represent the main source of compounds employed in drug discovery and development. Still now, nature provides the mankind with a diversity of small bioactive compounds, opening promising avenues for the treatment of a great variety of diseases. Indeed, through millions of years, natural products have evolved to encompass a broad spectrum of chemical and functional diversity that enables them to target of a nearly limitless number of biological macromolecules in a highly selective manner. In contrast, synthetic molecules generated by combinatorial chemistry show lower chemical diversity and selective action than their natural counterparts. Because of these characteristics, natural products, mostly plant secondary metabolites, have seen great success as therapeutic agents. In fact, about $50 \%$ of the drugs introduced in the market during the last 20 years were derived directly or indirectly from bioactive compounds. Interestingly, of the approximately 1,200 new medicines approved by the FDA in the 25-year period up to 2006, only around one-third of the small molecules were completely synthetic in origin, with the remaining being natural products, direct derivatives of natural products or synthetic compounds inspired by a natural product lead (Vuorelaa et al., 2004; Newman \& Cragg, 2009; Harvey, 2010).

Besides the known diversity of bioactive compounds, it is certain that a great number of novel nature-based molecular structural models, with novel biological activities, remain to be discovered. It is currently estimated that approximately 420,000 plant species exist in 
nature; the majority of which still unknown (Vuorelaa et al., 2004). In addition, less than $1 \%$ of microbes known by humans can be cultivable in laboratory conditions. In fact, the therapeutic potential of metabolism-derived microbial products is largely not explored, besides the astonishing number of different microorganisms that inhabit the Earth. Interestingly, despite our reduced knowledge of the microbial diversity, more than 20,000 secondary metabolites derived from microorganisms have already been described, while only a small percentage of these have been carried forward as natural product drugs (Knight et al., 2003). Marine organisms also represent a significant source of bioactive molecules, much of which in phase II, phase III and at the commercialization stage of new drug development (Galeano et al., 2011).

According to the World Health Organization (WHO), cancer is the leading cause of death worldwide and responsible for around 7 million deaths per year, a number estimated to reach 11 million until 2030. However, chemotherapy, the major therapeutic approach for cancer treatment, has to deal with important constrains such as lack of aqueous solubility and selectivity of antineoplastic drugs and the innate or acquired emergence of multidrug resistance by cancer cells. Consequently, there is an overwhelming demand for the discovery of novel chemopreventive compounds and to the development of new, more potent and effective, anticancer drugs. In this scenario, natural products represent the most valuable source of bioactive compounds able to inhibit cancer and serve as leads and scaffolds for the development of more efficacious drugs. Indeed, historically, natural products have been the most significant source of drugs and drug leads. Currently, around $74 \%$ of the available anticancer compounds are natural products or natural product-derived (Tan et al., 2006). With this perspective, in this chapter, we outline the historical importance and future perspectives of terrestrial and marine-sourced anticancer agents in oncology, and discuss the impact of novel biodiversity sources, such as venoms and toxins from several animal species, in anticancer drug development. In addition, some general aspects of chemical modifications done in natural products core with the aim to improve their activity and/or effectiveness are described.

\section{Plants as a valuable source of anticancer drugs}

Natural products with interesting biological activities and complex chemical structures with diverse functional groups result from the phenomenon of biodiversity, which means the richness in variety of organisms in the ecosphere (McChesney et al., 2007). These complex molecules evolve from a natural source of combinatorial chemistry, directed to select specific products with biological advantage. As a consequence of this natural selection, molecules able to interact specifically with biological targets arise, thus providing increased survival to the organisms that generated them. From a historical point of view, natural products have long been used as the mainstay of anticancer pharmacology.

From Podophyllum peltatum, which provided the podophyllotoxins in the early 1950s, to the Pacific yew Taxus brevifolia, from which emerged the most significant anticancer drug paclitaxel $\left(\right.$ Taxol $\left.^{\circledR}\right)$, plants have been a seemingly unimaginable source of effective new drugs. Indeed, since the development of the vinca alkaloids, vinblastine and vincristine, and the isolation of podophyllotoxins, from which derived the semisynthetic derivatives, etoposide and teniposide, plant-derived agents have consolidated their place in the chemotherapy armamentarium of anticancer drugs, remaining largely prescribed today and having decades of success in the clinical set (Cragg \& Newman, 2005; Newman \& Cragg, 2007; Bailly, 2009). 
Drug discovery from medicinal plants is an interdisciplinary and multi-stage process characterized by the collection and identification of plant species with known biological activities or randomly collected for screening purposes, extract preparation and biological screening for pharmacological properties in relevant experimental models, isolation and characterization of active compounds, and screening assays directed toward molecular targets (Balunas \& Kinghorn, 2005). Several strategies have been used to identify new compounds for drug discovery, of which natural products, and particularly medicinal plants, are still considered an important source of new drugs. Moreover, compounds with new biological activities can afford important drug leads in the development of new generations of drugs with specific and selective activities against novel molecular targets (Balunas \& Kinghorn, 2005; Bailly, 2009). During the glory decades, several classes of plantderived cytotoxic drugs have entered into clinical trials and some are in clinical use, such as camptothecin, isolated from Camptotheca acuminate, the precursor of the topotecan and irinotecan, homoharingtonine, isolated from the Chinese tree Cephalotaxus harringtonia, flavopiridol, a synthetic flavonoid structurally based in the natural product rohitukine, isolated from Dysoxylum binectariferum, combretastatin from the South African "bush willow" Combretum caffrum, vinorelbine, the major semi-synthetic tubulin-binding vinca alkaloid and the taxanes (Cragg \& Newman, 2005; Bailly, 2009).

The naphthoquinones, mainly lapachol and $\beta$-lapachone, are another class of anticancer agents that has been received most attention. While lapachol failed in clinical trials due to their toxicity, $\beta$-lapachone provides significant activity against tumor cell lines from different histological origins, including leukemia, breast, prostate and several multidrug resistant (MDR) cell lines. In addition to these effects, its ability to inhibit the enzyme Cdc25, a dual-specificity phosphatase that promotes cell cycle progression and has been postulated to be an oncogene, renewed interest in this family of compounds (Ravelo et al., 2004; Karlsson-Rosenthal \& Millar, 2006).

Sesquiterpene lactones encompass a class of terpenoids derived mainly from Asteraceae, but also found in Umbelliferae and Magnoliaciae, which have the ability to selectively target tumor and cancer stem cells. Artemisinin from Artemisia annua L, thapsigargin from Thapsia (Apiaceae) and parthenolide from Tanacetum parthenum and their synthetic derivatives are the most promising drugs of this family for cancer treatment (Ghantous et al., 2010). Studies indicate that their selectivity against tumor cells is achieved by different mechanisms, including modulation of specific signaling pathways, induction of oxidative stress, and epigenetic, antiangiogenic and antimetastatic activities. For instance, thapsigargin has been shown to inhibit the sarco/endoplasmic reticulum (ER) calcium ATPase (SERCA) pump, thus increasing intracellular $\mathrm{Ca}^{2+}$ levels, which ultimately lead to ER stress and cell death (Christensen et al., 2009; Winther et al., 2010). Artemisinin has shown promising antitumor properties in vitro and in vivo, entering phase I-II clinical trials against metastatic breast and colorectal cancers. As tumor cells express higher levels of transferrin receptors on cell surface and have higher concentrations of intracellular iron than normal or slowproliferating cells, cleavage of artemisinin endoperoxide bridge upon binding to Fe(II) and subsequent free radical generation in tumor cells have been associated to its toxicity. As simultaneous inactivation of p53 and hyperactivation of nuclear factor $\kappa B(N F \kappa B)$ is a common event in human cancers, drugs able to target both pathways have been considered interesting candidates for anticancer therapy. Both sesquiterpene lactones, parthenolide and artemisinin, are able to inhibit $\mathrm{NF \kappa B}$, rendering cancer cells sensitive to chemotherapy (Ghantous et al., 2010). In particular, parthenolide has been shown to inhibit NFkB and to 
activate p53 by promoting the ubiquitination and degradation of its negative regulator MDM2 (Gopal et al., 2009). Furthermore, the elevated NFKB signaling in leukemia stem cells compared to normal hematopoietic stem cells has been ascribed to parthenolide selectivity against acute myeloid leukemia (Ghantous et al., 2010). A more recent epigenetic role for parthenolide in cancer has been shown, by specifically inhibiting DNA methyltransferase 1 (DNMT1) and histone deacetylase 1 (HDAC1) activities, leading to DNA hypomethylation in vitro and in vivo (Liu et al., 2009; Ghantous et al., 2010).

Also, the ability of plant secondary metabolites, such as vitamins, isothiocyanates, quercetin, catechins, resveratrol, epigallocatechin-3-gallate (EGCG), genistein and curcumin, to prevent and/or inhibit tumor growth, either alone or in combination with other anticancer drugs and/or other phytochemicals has been documented (de Souza et al., 2005; Justo \& Ferreira, 2005; de Souza et al., 2006; Hemalswarya \& Doble, 2006; de Souza Queiroz et al., 2007; Newman \& Cragg, 2007; de Fátima et al., 2008a; Bailly, 2009; Camargo et al., 2011). In this respect, all-trans-retinoic acid (vitamin A) is now widely used for the treatment of myeloid leukemia (Sanz \& Lo-Coco, 2011) and vitamin D is in clinical trial for this disease (Trump et al., 2006). Recently, we provided evidence that photoderivatives of riboflavin, a constituent of the vitamin B complex (vitamin B2), possess strong activity in hematological malignancy as well (de Souza et al., 2006). The molecular mechanism involved the activation of caspase 8 induced by overexpression of Fas and FasL and mitochondrial amplification mechanisms associated with the stimulation of ceramide production by sphingomyelinase and ceramide synthase. In addition, activation of this cascade led to an inhibition of mitogen activated protein kinases cJun N-terminal kinase (JNK), extracellular signal-regulated kinase (ERK) kinase (MEK) and ERK and survival mediators [Protein kinase B (PKB/Akt) and inhibitor of apoptosis protein 1 (IAP1)], upregulation of pro-apoptotic Bax and downregulation of cell cycle progression regulators (de Souza et al., 2006). The potential of such vitamin-derived products in solid tumors was also demonstrated in androgen-independent human prostate cancer (PC3) cells (de Souza Queiroz et al., 2007). As reported earlier, riboflavin photoproducts are cytotoxic to these cells in a Fas-FasL-dependent manner. Furthermore, irradiated riboflavin inhibited matrix-degrading proteases, caused downregulation of vascular endothelial growth factor (VEGF) and upregulation of tissue inhibitor of metalloproteinase 1 (TIMP1), suggesting antimetastatic potential (de Souza Queiroz et al., 2007).

The anticancer properties of curcumin, a natural phytochemical obtained from dried root and rhizome of the spice turmeric (Curcuma longa), has long been studied, with few analogues showing promising results as future candidates for clinical development (de Fátima et al., 2008a; Ravindran et al., 2009; Agrawal \& Mishra, 2010). Decades of research have demonstrated that tumor cell death induced by curcumin occurred by a number of mechanisms, mostly by interfering with multiple cell signaling pathways, including the intrinsic and extrinsic apoptosis pathways, and the NFKB and phosphatidylinositol 3-kinase (PI3K)/ Akt signaling cascades. Furthermore, curcumin can be used for cancer prevention and it also sensitizes cancer cells to radiation and chemotherapeutic drugs (Kunnumakkara et al., 2008; Ravindran et al., 2009).

The flavonoid quercetin, which is abundantly present in fruits, vegetables, wine and tea, has revealed several properties such as antioxidant, antiproliferative and anticancer (Boots et al., 2008; Murakami et al., 2008). Cachexia is a poorly understood syndrome present in already compromised cancer patients, decreasing the quality of life and increasing mortality. Several studies have been performed in an attempt to find an effective way to treat cachexia, but none of the tested therapies has fulfilled expectations. Recently, Camargo and colleagues 
(2011), have demonstrated that intraperitoneal injections of quercetin reduced cachexia in rats bearing Walker 256 carcinosarcoma. Moreover, this effect was accompanied by tumor growth inhibition and increased survival. Evaluation of some of the mechanisms involved in quercetin activity showed decreased MMP-2 and VEGF levels in treated animals, suggesting angio-prevention and mitigation of invasion, effects that strongly support the anticancer property of this flavonoid (Camargo et al., 2011).

Even though plants have been an important source of drugs with great chemical diversity, a significant reduction in the number of plant-derived drug candidates occurred since 2000 (Bailly, 2009). Besides the lack of expected efficacy and toxicity, as well as, reduced aqueous solubility and problems with the determination of biological activities of complex extracts, which impair the development process of new drug candidates, issues related to difficulties with sourcing authenticated plant material and the quantity of drug needed for their development are major challenges to be overcome. In addition, the development of effective drugs from naturally occurring agents is time-consuming and requires considerable resources. These limitations, together with the advent of molecular target-based drug discovery programs in the 1990s, significantly impacted the development of the segment of natural product-based pharmacology, leading to a decline in the search for new hits (Schmidt et al., 2007; Bailly, 2009). Interestingly, the percentage of patents involving natural product derivatives remained almost unchanged during this period (Schmidt et al., 2007). Furthermore, despite the introduction of synthetic approaches in the universe of drug discovery, studies demonstrate that natural products and their derivatives continue to play a pivotal role in saving and prolonging the life of millions of patients (Mann, 2002; Newman et al., 2003; Cragg \& Newman, 2005; McChesney et al., 2007; Newman \& Cragg, 2007; Bailly, 2009). Such incredible better performance of natural products compared to randomly synthesized molecules is the consequence of the common evolutionary roots of plant natural products, enzymes, receptors and proteins, which arise to interact with one another (Schmidt et al., 2007). Thus, the search for drugs from novel biodiversity sources combined with the identification of new targets are still considered as one of the most important strategies to find innovative drug candidates (McChesney et al., 2007; Schmidt et al., 2007; Bailly, 2009), leading to the optimism that novel drugs derived from plants are forthcoming.

\section{The microbial world of anticancer drugs}

In the world of life organisms the primary metabolism represents the anabolic and catabolic processes that are essential for organism growth and reproduction. In this way, the primary metabolism pathways and the primary metabolites are highly conserved across species, genera, and kingdoms. In contrast, the secondary metabolism works for organism adaptation and secondary metabolites are produced by individual species or genera for specific physiological, social or predatory reasons. These compounds therefore are specie/genera specifics and, given the impressing diversity of life organisms on Earth, constitute a valuable source of complex and intricate structures with a wide range of biological activities.

Microbial-derived secondary metabolites are low molecular mass products ( $<3,000$ Daltons) characterized by unusual and complex structures. Indeed, competition for survival and environmental pressures drive the evolution of defense, attack and signaling diversity, which, in turn, determine chemical and biological diversity and potential new drugs. They are represented by peptides, polyketides, carbohydrates, lipids, terpenoids, steroids and alkaloids, most of which used directly or indirectly as scaffolds for antibiotic, antitumor and 
cholesterol-lowering drug synthesis. The importance of such compounds in the treatment of a wide range of diseases is demonstrated by the fact that $40 \%$ of new drugs discovered since 1980 were derived from natural microbial sources (Koehn \& Carter, 2005).

Environmental microbes - mainly actinomycetes, bacilli and filamentous fungi - have an enormous capacity to produce secondary metabolites, which have been exploited for drug discovery. By 2002, microbes were the source for 22,500 bioactive compounds. Of these, $17 \%$ were obtained from unicellular bacteria (mainly Pseudomonas and Bacillus), 45\% from filamentous bacteria (Actinomycetes) and 38\% from fungi (Demain, 2009; Singh \& Macdonald, 2010). For over 40 years, natural small organic molecules derived from microbes and plants have played a very important role as established anticancer chemotherapeutics. In particular, microbes have been recognized to contribute significantly to this field. Currently, antibiotics with antitumoral activity have been used in the treatment of cancer patients as the case of anthracyclines (such as doxorubicin), bleomycin, dactinomycin (actinomycin), and mitomycin C (Kinghorn et al., 2009).

Pericosines A-E are a family of cytotoxic metabolites isolated from Periconia byssoides OUPSN133, a fungus that was collected from the sea hare Aplysia kurodai. Among the members of this family of carbasugars, pericosine $\mathrm{A}$ is the most important, because it was reported to possess significant inhibitory activity against protein kinase EGFR (epidermal growth factor receptor) and human topoisomerase II, in addition to its antitumor activity against P388 lymphocytic leukemia cell line in vitro and in vivo (Numata et al., 1997; Yamada et al., 2007). Various reports in literature have shown the efforts of researchers to characterize the structure of pericosine molecules and develop new routes for their synthesis (Usami et al., 2009).

Since 1941, when penicillin was introduced in the market, secondary metabolites of bacteria have been studied as promising drug candidates for the treatment of diverse pathologies, including cancer. Many bacterial products such as proteins, enzymes, immunotoxins, secondary metabolites or even naked DNA can be used or adapted in a proper manner to specifically target cancer cells, causing tumor regression through growth inhibition, cell cycle arrest or apoptosis induction. Interestingly, many bacterial compounds also inhibit cancer metastasis.

Some bacterial enzymes are potential candidate therapeutic agents for cancer treatment. The enzyme arginine deiminase (ADI), found in Mycoplasma arginine and P. aeruginosa among others, is an example of bacterial product that combat cancer cells through its ability to cause arginine depletion and consequent nutritional stress in cancer cells. Curiously, while arginine is a nonessential amino acid in humans, some cancers, such as hepatocellular carcinoma, melanoma and renal cell carcinomas, do not synthesize arginine, making ADI a promising enzyme for the selective elimination of such cancer cells through arginine deprivation. Furthermore, the crystal structure of ADI demonstrated that this enzyme harbor a putative CARD-like domain (caspase activation domain) with no significant amino acid sequence homology. In this way, it seems that ADI could be a selective inductor of cancer nutritional stress through its enzyme activity, while in the absence of catalytic activity the enzyme could act as a selective inductor of caspase activity and programmed cell death in cancer cells (Barile \& Leventhal, 1968; Das et al., 2004). Another bacterial product that exploit cancer metabolism to induce cell death is L-methioninase, a ubiquitous enzyme expressed in all organisms including bacteria, fungi, protozoa, and plants, except in mammals. L-Methioninase is a pyridoxal 5'-phosphate dependent enzyme that catalyzes the direct $\gamma$-conversion of L-methionine to methanethiol, $\alpha$-ketobutyrate, and ammonia. LMethionine is an essential amino acid with several critical functions, including biosynthesis 
of protein, glutathione, and polyamines, in addition to the methylation of DNA, thus regulating gene expression. As in the case of arginine, cancer cells are not able to synthesize methionine and need an external supply of this amino acid to keep alive. Thus inhibiting the use of methionine by cancer cells through L-methioninase has been pointed as a relevant strategy to improve conventional anticancer therapies. However, studies have shown that the therapeutic response of the bacterial enzyme is usually associated with high immunogenicity, low substrate specificity, and hazardous effects to the kidney and liver. In contrast, L-methioninase from eukaryotes may be characterized by their lower immunogenicity reinforcing the need for extensive biochemical and pharmacokinetic characterization of this enzyme from organisms like fungi, which are able to produce it efficiently (El-Sayed, 2010).

Bacterial products can also combat cancer through inhibition of the HDAC enzyme. Romidepsin (FK228), a naturally occurring depsipeptide isolated from Chromobacterium violaceum, is a potent HDAC inhibitor with anticancer activity against leukemia, colon cancer and neuroblastoma cell lines, human tumor xenografts and murine tumors, and is therefore expected to be a novel and promising anticancer drug, currently under clinical evaluation in the USA (Ueda et al., 1994; Schrump et al., 2008; Piekarz et al., 2009; Mizutani et al., 2010; Panicker et al., 2010). The mechanism of FK228 induction of cancer demise is incompletely known but it seems associated with the ability of this compound to induce hydrogen peroxide synthesis, activation of caspases and programmed cell death (Mizutani et al., 2010). Inhibitors of HDAC are also found in extracts of Pseudomonas. Spiruchostatin A (also known as YM753) and B closely resemble FK228, exhibiting greater potency as HDAC inhibitors than several other compounds including FK228, making them promising anticancer agents (Crabb et al., 2008; Shindoh et al., 2008). In addition to FK228, another major product of $C$. violaceum metabolism, named violacein, has been extensively studied for its several biological activities (Durán et al., 2007). Of note, this purple-colored pigment has gained attention for its antitumor properties, which has been demonstrated in vitro against a number of cancer cell lines from several histological origins, as well as in vivo (Melo et al., 2003; Ferreira et al., 2004; Kodach et al., 2006; Durán et al., 2007; Bromberg et al., 2010). Moreover, studies have shown the ability of violacein to induce apoptosis by mechanisms that include modulation of a number of signaling pathways and the generation of oxidative stress (Melo et al., 2003; Ferreira et al., 2004; Kodach et al., 2006; Durán et al., 2007; Bromberg et al., 2010). Importantly, treatment of Ehrlich ascites tumor (EAT)-bearing mice with micromolar doses of violacein inhibited the tumor volume, the number of viable tumor cells and increased survival, differing from other works with natural products in the literature which spend high doses of the compounds. In addition to present a lower toxicity to normal cells in vitro, hematology, biochemistry and histopathological analyses of liver and kidney of mice receiving daily intraperitoneal doses of violacein up to $1 \mathrm{mg} / \mathrm{kg}$ indicated that treatment with violacein is well tolerated and does not cause hematotoxicity nor renal or hepatotoxicity (Durán et al., 2007; Bromberg et al., 2005; Bromberg et al., 2010). At this point, it is important to mention that the Amazonian strain of C. violaceum (from Rio Negro, Brazil) produces violacein at a higher rate compared to other strains, including the ATCC 553 strain, as well as other bacteria, such as Janthinobacterium lividum and Alteromonas luteoviolacea. Also, using the Brazilian strain, the biotechnological process of violacein production was optimized by our group, resulting in higher yields of the compound (Durán et al., 2007).

Immunotoxins constitute another source of bacterial compounds with potential use in the antitumoral therapies. Exotoxin A-immunotoxins, such as that produced by $P$. aeruginosa, 
kill cancer cells by binding specifically to overexpressed cell surface receptors, which carries them into the cell, where they catalyze the ADP-ribosylation of the eukaryotic elongation factor 2 (eEF-2) in host cells, ultimately affecting protein synthesis and inducing programmed cell death. Clinical trials with different exotoxin A-immunotoxins have demonstrated that such bacterial products present better results in eliminating cells derived from hematological malignancies over those originated from solid tumors (Wolf \& ElsasserBeile, 2009; Bernardes et al., 2010). P. aeruginosa has also been demonstrated to produce another immunoglobulin-like product named azurin, a water soluble enzyme involved in the electron transport chain. Azurin has its secretion enhanced from P. aeruginosa in response to the presence of human cancer cells. Furthermore, azurin is known to enter preferentially into cancer cells and has multiple antitumor activities (Mahfouz et al., 2007). Azurin binds and stabilizes the tumor suppressor protein p53 besides its ability to bind and inhibit the activity of several Ephrin (Eph) receptor tyrosine kinases, a family of extracellular receptor proteins known to be upregulated in many tumors. Azurin-induced stabilization of p53 results in the increased expression of proapoptotic proteins, thus contributing for the triggering of programmed cell death in cancer cells (Xu et al., 2010). Binding and inhibition of Eph receptors by azurin avoid the activation of cellular signaling pathways that stimulate proliferation, migration, invasion and angiogenesis of many types of human tumors (Chaudhari et al., 2007). Interestingly, P. aeruginosa not only secretes azurin, but simultaneously releases in the growth medium an extrachromosomal DNA element rich in stretches of unmethylated $\mathrm{CpG}$ dinucleotides. This molecule demonstrates antitumor activity through TLR9 activation and cytokine/chemokine production and allows cancer cell death. In addition to P. aeruginosa other bacteria, such as Mycobacterium bovis, also secrete unmethylated CpG dinucleotides with antitumor activities (Mahfouz et al., 2007). Recently, preclinical studies were done with the azurin-p28 (NSC 745104), an amphipathic, 28 amino acid fragment (aa 50-77) of the azurin. The results demonstrated that p28 does not exhibit preclinical immunogenicity or toxicity, has a similar metabolic profile among species, and is therapeutic in xenograft models (Xu et al., 2010).

The Ras GTPases (HRAS, NRAS and KRAS) are the founding members of a large superfamily of monomeric small (20-25 kDa) GTPases that regulate diverse cellular processes, including those associated with cancer progression, such as proliferation, differentiation, cell survival and migration. Mutational activation of Ras is found in about $33 \%$ of human cancers, making these proteins important targets for reaching successful cancer treatments (Vigil et al., 2010). Activation of the Ras oncogene requires the linkage of a farnesyl group, allowing the protein anchorage to the cell membrane and the subsequent interaction with guanosine exchange factors located in receptor-associated complexes. Some Ras family proteins such as KRAS can be alternatively activated through the addition of a geranylgeranyl moiety. Farnesyltransferase inhibitors (FTI) are metabolites capable of blocking this step, thus impairing Ras activation, even in the presence of a mutant Ras. Several FTIs of microbial origin have been discovered in the past few years specially among fungi (Vilella et al., 2000; Iwasaki \& Omura, 2007). Fungi, like Aspergillus terreus, Monascus ruber and Pleurotus ostreatus, produce lovastatin, a member of the drug class of statins, which blocks Ras activation through inhibition of farnesylation and induces apoptosis (Laezza et al., 2008). Manumycin A, a competitive farnesyltransferase inhibitor, is an antibiotic detected in the culture media of a Streptomyces strain that has shown both in vitro cytotoxic activity against several cell lines (human pancreatic tumor, breast and colon cancers, thyroid carcinoma, leukemias, myeloma and hepatocellular carcinoma) and in vivo against human 
cancer xenograft models (Bernardes et al., 2010). Gliotoxin is a member of the epipolythiodioxopiperazine class of toxins and is both the major and the most potent toxin produced by Aspergillus fumigatus. Gliotoxin and KT7595, a gliotoxin derivative, inhibited DNA synthesis, cellular proliferation and Ras farnesylation in human colon carcinoma, hepatoma and gastric carcinoma (Nagase et al., 1997).

Many secondary metabolites from bacterial origin have entered clinical trials as antitumor drugs. Prodiginines and its derivatives, like prodigiosin and obatoclax, demonstrate powerful and selective anticancer activity against several cancer-derived cell lines, while little or no activity has been documented against normal cells. Importantly, these bacterial metabolites seem to be resistant to multidrug pumps that are often responsible for inducing resistance to other anticancer agents (Nguyen et al., 2007). The epothilones were initially isolated from the slime mold Sorangium cellulosum as antifungal compounds. Today, this class of compounds is recognized by its valuable action as microtubule-stabilizing agents that have demonstrated antitumor activity in taxane-resistant models and in cancer cells displaying MDR disease. Natural epothilones B and D and many derivatives are under investigation in several pre-clinical, and phase I and II clinical trials. At this time, ixabepilone (BMS) is the sole drug to reach the market, although sagopilone (Bayer) is currently in phase II clinical trials (Beutler, 2011; Nobili et al., 2011).

Cancer metastasis occurs during tumor progression and causes $90 \%$ of human cancer deaths. Many bacteria, like Staphylococcus aureus, naturally produce several chemokine/adhesion receptor inhibitors, which actions avoid cancer cell migration. Staphylococcal superantigenslike (SSL) molecules, such as SSL10 and SSL5, showed to bind specific receptors displayed by cervical and leukemia cells, inhibiting their ability to spread through other tissues in the body (Walenkamp et al., 2009; Walenkamp et al., 2010).

Finally, cancer treatment can also be done using live, attenuated or engineered bacteria. Clostridium, Bifidobacterium, Salmonella, Mycobacterium, Bacillus and Listeria have the ability to selectively target cancer cells and act as anticancer agents. They grow in the hypoxic core region of solid tumors, where most of the time radiation or chemotherapy is unsuccessful. In addition, thanks to their selectivity for the tumor microenvironment, these bacteria are also promising vectors for delivering therapeutic genes for anticancer therapies (Bernardes et al., 2010).

As discussed here, microbes constitute a great source of anticancer therapeutic compounds. Indeed microbes are the most diverse (both structurally and metabolically) and abundant group of organisms and account for $60 \%$ of the Earth's biomass. However, genomic studies indicate that certain groups of bacteria and fungi have dozens of secondary metabolite pathways that are not expressed under standard laboratory growth conditions. In fact, $>99 \%$ of environmental microbes are uncultivable, limiting the discovery of new products (Singh \& Macdonald, 2010). In this way, understanding community and functional diversity is essential for exploiting the potential of microbes as a source of new drugs. Recently, with the advent of new technologies and genomic data, the discovery of novel drugs from uncultivable microbes has become a reality that brings new opportunities for the development of new anticancer drugs. In particular, metagenomics has been highlighted as a promising strategy for this goal. Metagenomics allows the extraction of total genetic materials from environmental samples followed by its transferring into new host cells, mainly Escherichia coli, to generate metagenomic libraries. Using these libraries it is possible to study structural and functional diversity by DNA sequencing or to search for new products based on sequence mining or functional expression without the need for culturing 
microbes. In addition, whole genome sequencing have contributed for the discovery of new secondary metabolites with therapeutic effects, as the case of the anticancer drugs diazepinomicin and Eco-7942, discovered from the genome mining of Micromonospora and Streptomyces spp (Singh \& Macdonald, 2010). Furthermore, secondary metabolite pathways, which are not expressed under standard laboratory growth conditions, can be synthesized in the presence of neighboring microbes; a strategy named mixed fermentation. Research to date indicates that mixed fermentation can result in increased antibiotic activity in crude extracts, increased yield of previously described metabolites as well as previously undetected metabolites, analogues of known metabolites resulting from combined pathways and, importantly, induction of previously unexpressed pathways for bioactive constituents (Pettit, 2009). In conclusion, microorganisms constitute a rich source of potential antitumor compounds. Exploring this diverse group of living organisms is a challenge, but a promising strategy. In addition, it is certain that the use of genetic approaches and mixed fermentation will open new opportunities for the discovery of novel therapeutic compounds "hidden" in the genetic information load by such organisms.

\section{Venoms and toxins as potential anticancer drugs}

Anticancer therapy is one of the main areas for the use of proteins and peptides originating from animals. Some of these proteins or peptides, when isolated, may bind specifically to cancer cell membranes, affecting the migration and proliferation of these cells. Venoms and toxins from snakes, scorpions, frogs, spiders, bee, wasps, ants, centipedes and caterpillars may hold the promises for treating many types of malignancies, especially with the demonstration of complete remission of cancer cells after treatment with molecules derived from animal venom. However, studies focusing on the mechanisms by which these venoms act are still very recent, and much has yet to be found out about these molecules.

\subsection{Snake venom and toxins}

The presence of anticancer enzymes in snake venom has been reported and phospholipase activity, found in cobra venom, was ascribed to be the enzyme with anticancer potential (Braganca \& Khandeparker, 1966). Phospholipase B in the venom of the Australian elapid snake was cytotoxic to cultured rhabdomyosarcoma cells (Bernheimer et al., 1987). Phospholipase A2 (PLA2), isolated from Bothrops newweidii venom, has cytotoxic activity in B16F10 melanoma cells (Daniele et. al., 1997), and two toxic PLA2 have been purified from the Indian cobra (Naja naja naja) venom, which are neurotoxins presenting cytotoxicity against EAT cells (Basavarajappa \& Gowda, 1992).

The Arg-Gly-Asp (RGD)-containing disintegrins are non-enzymatic proteins that inhibit cell-cell interactions, cell-matrix interactions, and signal transduction. Disintegrins also have the ability to inhibit several aspects of tumor cell behavior, both in vitro and in vivo, including adhesion, migration, invasion, metastasis and angiogenesis (Swenson et al., 2007). A disintegrin named Salmosin was isolated from Korean snake venom and effectively suppressed growth of metastatic tumor, as well as solid tumor in mice (Kang et al., 1999). Contortrostatin, a dimeric disintegrin isolated from Southern copperhead snake venom, prevented invasion of human breast cancer cells through an artificial matrigel basement membrane. Phospholipases, disintegrins and other enzymes of snake venom could progress as a therapeutic tool in the treatment of various cancers and thrombotic diseases in the near future (Gomes et al., 2010). 


\subsection{Scorpion venom and toxins}

The repertoire of scorpion venoms presents a complex mixture of a large variety of molecules that play an important role in the defense and capture of prey. They contain mucopolysaccarides, phospholipases, hyaluronidases, protease inhibitors, low molecular weight molecules such as serotonin and histamine, histamine releasing peptides, inorganic salts, mucus, and many basic small proteins known as neurotoxic peptides (MartinEauclaire \& Couraud, 1995). The neurotoxic peptides have specific interaction with ion channels, making scorpion venom capable of binding specifically to certain types of cells, such as cancer cells. Therefore, this type of venom holds molecules that are of interest to the pharmaceutical industry in terms of drug design and development. Scorpion toxins are important molecules to fight cancer, since they have shown both in vitro and in vivo effects in cancer cells, as well as in phase I and phase II clinical trials. The most studied peptides are the long chain toxins composed of 60-70 amino acid residues cross-linked by four disulfide bridges. These peptides activate mainly $\mathrm{Na}^{+}$channels. They are divided in two major classes: a-toxins and b-toxins (Possani et al., 2001). Short chain toxins with 30-40 amino acid residues cross-linked by three disulfide bridges form another polypeptide family, acting mainly upon $\mathrm{K}^{+}$or $\mathrm{Cl}^{-}$channels. The venom also contains peptides without disulfide bridges that act in other targets besides ion channels (Goudet et al., 2002).

Chlorotoxin (Cltx) is a peptide from the species Leiurus quinquestriatus that inhibits chloride influx in the membrane of glioma cells. This peptide binds only to glioma cells, displaying little or no activity at all in normal cells. The toxin appears to bind MMP-2 (Deshane et al., 2003; Veiseh et al., 2007), an extracellular matrix enzyme that exhibits gelatinase activity. MMP-2, a proteinase involved in tumor invasion, is specifically upregulated in gliomas and related cancers, but is not expressed in normal brain cells. Cltx binds effectively to MMP-2 endogenously expressed by glioma cells (Deshane et al., 2003; Veiseh et al., 2007) and its exposure to Cltx results in loss of gelatinase activity, disruption in chloride channel currents, reduction in both MMP-2 and chloride channel expressions, and internalization of chloride channels (Veiseh et al., 2007). Thus, these data indicate that venoms from scorpions represent important candidates for the development of new clinical treatments against tumors. However, further studies are necessary to isolate and characterize their active molecules (Heinen et al., 2011).

\subsection{Spider venom and toxins}

Spider venoms contain a complex mixture of proteins, polypeptides, neurotoxins, nucleic acids, free amino acids, inorganic salts and monoamines that cause diverse effects in vertebrates and invertebrates (Ori \& Ikeda, 1998). Regarding the pharmacology and biochemistry of spider venoms, they present a variety of ion channel toxins, novel nonneurotoxins, enzymes and low molecular weight compounds (Rash \& Hodgson, 2002). The enzyme phospholipase D has been isolated and purified from the venom of brown spider that displays high hemolytic activity (Silva et al., 2004), which could present anticancer action. Also, hyaluronidases found in the venom of some spiders could be used to increase tissue permeability, thus facilitating the penetration of some drugs, or even being employed directly as antitumor agents (Girisk \& Kemparaju, 2007). Other toxins that have been isolated are the oxyopinins from the wolf spider Oxyopes kitabensis, which form pores in lipid membranes (Corzo et al., 2002) and could also be considered as candidates for anticancer therapy (Shaposhnikova et al., 1997). 
Psalmotoxin 1 isolated from a West Indies tarantula, is a 40-amino acid peptide that inhibits cation currents mediated by acid-sensing ion channels (ASIC) (Escoubas et al., 2000). Bubien and colleagues (2004), using this molecule, inhibited $\mathrm{Na}^{+}$currents in high-grade human astrocytoma cells (glioblastoma multiforme, or GBM) (Bubien et al., 2004). The antitumor activity of a potent antimicrobial peptide isolated from hemocytes of the spider Acanthoscurria gomesiana, named gomesin, was tested in vitro and in vivo (Rodrigues et al., 2008). Gomesin showed cytotoxic and antitumor activities in cell lines, such as melanoma, breast cancer and colon carcinoma.

\subsection{Toad and frog venoms and toxins}

The experiments with the skin extract (TSE) of common Indian toad (Bufo melanostictus, Scheneider) exhibited significant antineoplastic activity against EAT cells and human leukemia cell lines U937 and K562 (Giri \& Gomes, 2004). Leukemia growth inhibition due to TSE was mediated by cell cycle arrest in G1 phase. A large number of early and late apoptotic cells were found in TSE-treated leukemia cells as compared to the untreated cells (Giri et al., 2006). Bufadienolides are molecules present in the skin of toad of the genus Bufo. The cytotoxic activity of toad bufadienolides was described in primary liver carcinoma PLC/PRF/5 cells (Kamano et al., 1998). Cinobufagin was isolated from Bufo siccus and showed in vitro inhibitory effect in five types of human cancer cells (Chen et al., 1998). The cytotoxic activity of bufalin and cinobufagin in prostate cancer cells was associated with constant increase in $\mathrm{Ca}^{2+}$, leading to apoptosis (Yeh et al., 2003). Brevinin-2R, a non-hemolytic defensin has been isolated from the skin of the frog Rana ridibunda. It showed pronounced cytotoxicity towards malignant cells, including Jurkat (T-cell leukemia), B-cell lymphoma, colon carcinoma, fibrosarcoma, breast adenocarcinoma and lung carcinoma (Ghavami et al., 2008).

\subsection{Bee and wasp venoms and toxins}

The melittin and PLA2 are two substances that have been isolated and characterized from bee venoms. Several studies have been published showing their antitumoral effects (Ownby et al., 1997). The melittin enzyme exhibits antimicrobial activities and proinflammatory effects (Sumikura et al., 2003), besides inducing perturbations in the cell membrane and damage to enzyme systems (Wade et al., 1990). Several cancer cells, including leukemia, renal, lung, liver, prostate, bladder, and mammary cancer cells, can be targets of melittin (Son et al., 2007). Melittin has also been reported as a PLA2 activator, increasing the calpain activity and cell necrosis in the hepatocellular carcinoma (Arora et al., 1996).

Research involving wasps shows a complex gland responsible for the production and injection of venom, which exhibits physiological, pharmacological and biochemical activities, playing a role in a variety of survival mechanisms such as defense against predators and prey capture, among others (Yu et al., 2007). Mastoparan, a peptide obtained from wasp venom has been reported to induce the formation of the mitochondrial permeability transition pore (Pfeiffer et al., 1995), and based on its capacity to induce mitochondrial permeability and the lack of specificity for tumor cells, Yamada and colleagues (2005) encapsulated this molecule with a transferrin-modified liposome with a $\mathrm{pH}$ sensitive fusogenic peptide (GALA), for selective delivery to mitochondria of K562 cells. This liposome targeted cells having high expression of transferrin receptors, which mediate its internalization by endocytosis. Results have shown that the encapsulated mastoparan was able to release cytochrome $c$, indicating its potential as an anticancer agent (Yamada et 
al., 2005). Fujiwara and colleagues (2008) determined the structure of an anticancer molecule from Vespa simillima. This molecule is a biologically active quinone, 7,8-seco- $p$-ferruginone $(\mathrm{SPF})$, which exhibited growth inhibitory effect in rat liver cancer cells. The analyses suggest that its cytotoxic activity is related to the morphological changes that induce apoptosis of cells exposed to this molecule (Fujiwara et al., 2008).

\subsection{Ant, centipede and caterpillar venoms and toxins}

The solenopsin A is a primary alkaloid from the fire ant Solenopsis invicta, having antiangiogenic activity. In order to analyze the antiangiogenic activity, studies were conducted to investigate the ability of this toxin to inhibit a series of kinases involved in this process (Bai et al., 2003).

An important study reporting centipede venom antitumor action has shown that a synthetic compound, Man $\beta(1-4)[F u c \alpha(1-3)]$ Glc $\beta 1-C e r$, (glycosphingolipid 7), from Parafontaria laminate armigera, exhibits antiproliferative effects in melanoma cells. This compound suppressed the activation of the focal adhesion kinase (FAK) and ERK pathways, which are both involved in melanoma cell proliferation (Sonoda et al., 2008).

The cecropins are a group of peptides isolated from the hemolymph Hyalophora cecropia that display antimicrobial activity (Andreu et al.,1985), and have been used as potent anticancer agents against a variety of tumor cell lines (Suttmann et al., 2008). The mechanism of action of cecropins against tumor cells appears to involve the formation of pores in the membrane of cells (Chen et al., 1997).

Lonomia obliqua induces a hemorrhagic syndrome in humans that accidentally get in touch with its urticating spines. Many molecules from the venom of L. obliqua have been isolated and characterized, including fibrinogenases (Pinto et al., 2006; Veiga et al., 2003), hyaluronidases (Gouveia et al., 2005) and an antiapoptotic protein (Souza et al., 2005). The PLA2 hydrolizes the sn-2 bond in phospholipids, generating fatty acids and lysophospholipids. The so formed lysophospholipids affect the lipid bilayer of cell membranes, leading to cell lysis, while the generated arachidonic acid promotes the activation of caspases and release of cytochrome $c$, culminating in apoptosis in some cell types (Zhao et al., 2002).

It is clear from these data that venoms and toxins from animals can present important pharmacological activities in human physiology. The substances found in the venom of these animals present great potential as antitumor agents. The understanding of the molecular basis of the envenomation processes caused by venoms from snakes, spiders, scorpions, frog, toad, caterpillars and bees are important for the diagnosis and treatment of the clinical profile, but research in the near future with venoms and toxins will definitely add information in the area of cancer biology.

\section{Anticancer drugs from marine life}

The biological diversity of the marine environment is an untapped source of compounds with several bioactivities and, therefore, is an extraordinary resource for the discovery of new anticancer drugs. The marine environment corresponds to $95 \%$ of the biosphere, and all except one of the 33 animal phyla are represented in aquatic environments. In addition, there are several organisms that are found in marine environment like seaweed, jellyfishes, and anemones. The majority of marine species are found near the coast, where there is a high number of species, being one of the most productive environments, with an impressive biodiversity. The large number of organisms living in this habitat is constantly fighting. One of the weapons used in these battles are molecules that are synthesized by marine species. 
Many of these molecules have important activities for humans, including medicinal properties, such as antitumor. Invertebrates and seaweeds are sources of anticancer drugs from marine resources (Lin et al., 2010). In this section, we highlight the past and current status of several marine anticancer compounds from different marine groups.

\subsection{Anticancer secondary metabolites}

The past decade witnessed a dramatic increase in the number of preclinical anticancer lead compounds from diverse marine life entering human clinical trials and several mechanisms of action were suggested. An example is agosterol A, which reversed the resistance to colchicine in KB-C2 cells (P-glycoprotein (P-gp)-mediated multidrug resistant cells) and also the resistance to vincristine in KB-CV60 cells (multidrug resistance-associated protein (MRP1)-mediated multidrug resistant cells), because it directly inhibited drug efflux through P-gp and/or MRP1 pumps (Aoki et al., 2001).

Cephalostatin, a bis-steroidal isolated from the tube worm Cephalodiscus gilchristi, induces selectively second mitochondria-derived activator of caspase (Smac)/direct IAP binding protein with Low pI (DIABLO), but no cytochrome $c$ release from mitochondria. Nevertheless, caspase 9 is required for apoptosis induction. Interestingly, caspase 9 is activated without the participation of the apoptosome (Rudy et al., 2008). Recently, its enantioselective synthesis was described (Fortner et al., 2010).

Bistramine $\mathrm{A}$ is a polyketide derivative isolated from ascidian such as Lissoclinum bistratum, but it is also found in a tunicate Trididemnum cyclops (Murphy et al., 2009). This compound disrupted the actin cytoskeleton, depolymerized F-actin in vitro and bound directly to monomeric G-actin (Rizvi et al., 2010).

Laulimalide was isolated in 1999 from the marine sponge Cacospongia mycofijiensis. This molecule stabilizes microtubules in a similar manner to paclitaxel, but it does not bind to the taxoid site on tubulin. It also kills cells resistant to epothilones and paclitaxel (Pryor et al., 2002; Khrapunovich-Baine et al., 2011). Other pharmacological information of several marine intermediate metabolites, with previously determined or undetermined mechanisms of action, is summarized in Table 1.

\subsection{Anticancer sulfated polysaccharides}

Marine sulfated polysaccharides are found mainly in seaweeds (green, red and brown seaweeds). The well known antitumor polysaccharides from red seaweed are homogalactans, and from brown algae are $\alpha$-L-fucose-containing sulfated homo and heteropolysaccharides, called fucan and fucoidan, respectively. There is a greater incidence of anticoagulant activity in extracts of the brown algae compared to red and green algae. Few studies describe the presence of anticancer sulfated polysaccharides in green algae, which are mainly heteropolysaccharides (Jiao et al., 2011).

The $\lambda$-carragennan (sulfated galactan) from the red seaweed Chondrus ocellatus did not inhibit sarcoma S180 and H22 hepatocarcinoma cells in culture. However, when these cells were implanted subcutaneously in mice, the $\lambda$-carragennan inhibits the growth of the tumors, supporting a role for the immune system in the antitumor activity of these compounds (Zhou et al., 2004). A sulfated galactan, porphyran, extracted from Porphyra yezoensis, induces caspase 3 activation and apoptosis in AGS gastric cancer cells without affecting the growth of normal cells (Kwon \& Nam, 2006). A sulfated heteropolysaccharide obtained from the green seaweed Capsosiphon fulvescens inhibits AGS gastric cancer cell 


\begin{tabular}{|c|c|c|}
\hline Source & & \\
\hline Sponges & Compound & Mechanism of action \\
\hline Halichondria okadai & Halichondrin B & Inhibits tubulin polymerization \\
\hline Discodermia dissolute & Discodermolide & Induces a senescent phenotype \\
\hline $\begin{array}{l}\text { Pseudoceratina } \\
\text { purpurea }\end{array}$ & Psammaplins & Activates PPR $\gamma$; inhibits DNMT and HDAC \\
\hline Hemiasterella minor & Hemiasterlin & Antitubulin activity \\
\hline Agelas mauritianus & Agelasphin & Immunostimulant compound \\
\hline Jaspis digonoxea & $\begin{array}{l}\text { Bengamide B } \\
\text { derivative }\end{array}$ & Methionine aminopeptidase \\
\hline Xestospongia sp. & Aaptamine & G2/M cell cycle arrest; affects p21 activity \\
\hline Reniera sarai & $\begin{array}{l}\text { Alkylpyridinium } \\
\text { salts }\end{array}$ & Cholinesterase inhibitor \\
\hline Mycale adhaerens & 13-Deoxytedanoli & $\begin{array}{l}\text { Binds to the } 605 \text { large ribosomal subunit and } \\
\text { inhibits polypeptide elongation }\end{array}$ \\
\hline Petrosia sp. & Dideoxypetrosynol & $\begin{array}{l}\text { Caspases } 3 \text { and } 9 \text { activation; degradation of } \\
\text { poly(ADP-ribose) polymerase (PARP) }\end{array}$ \\
\hline Cliona varians & CvL lectin & $\begin{array}{l}\text { Caspase-independent cell death; Lysosomal } \\
\text { cathepsin B-mediated cell death }\end{array}$ \\
\hline Tunicates & Compound & Mechanism of action \\
\hline Ecteinascidia turbinate & Ecteinascidin 743 & Tubulin inhibition \\
\hline Aplidium albicans & $\begin{array}{l}\text { Dehydrodidemnin } \\
\text { B }\end{array}$ & $\begin{array}{l}\text { Ornithine decarboxylase; interruption of } \\
\text { tumor cell cycle at G1 and G2. }\end{array}$ \\
\hline Trididemnum solidum & Didemnin B & Protein synthesis inhibitor \\
\hline $\begin{array}{l}\text { Didemnum cuculiferum } \\
\text { and Polysyncraton } \\
\text { lithostrotum }\end{array}$ & Vitilevuamide & Inhibits tubulin polymerization \\
\hline Cystodytes dellechiajei & Ascididemin & $\begin{array}{l}\text { Telomerase inhibitor; activation of caspase } 2 \\
\text { and JNK }\end{array}$ \\
\hline Molluscs & Compound & Mechanism of action \\
\hline Dolabella auricularia & $\begin{array}{l}\text { Dolastatin 10; } \\
\text { Synthadotin }\end{array}$ & Binds to tubulin \\
\hline Elysia rufescens & Kahalalide F & $\begin{array}{l}\text { Induces cell death via oncosis, preferentially } \\
\text { in tumor cells }\end{array}$ \\
\hline Lamellaria sp. & Lamellarin D & Inhibitor of DNA topoisomerase I \\
\hline Mactromeris polynyma & Spisulosine & $\begin{array}{l}\text { Promotes intracellular ceramide accumulation } \\
\text { and Protein kinase } \mathrm{C} \zeta(\mathrm{PKC} \zeta) \text { activation }\end{array}$ \\
\hline Ecteinascidia turbinata & Trabectedin & $\begin{array}{l}\text { Production of superoxide near the DNA } \\
\text { strand, resulting in DNA backbone cleavage }\end{array}$ \\
\hline Aplysia kurodai & Aplyronine A & Binds to hydrophobic cleft in actin molecule \\
\hline
\end{tabular}




\begin{tabular}{|c|c|c|}
\hline Bacterium & Compound & Mechanism of action \\
\hline Lyngbya majuscula & Laxaphycins A \& B & Increases polyploidy \\
\hline Salinispora tropica & Salinosporamide A & Proteasome inhibitor \\
\hline Several species & Cryptophycin & Antimicrotubule agent \\
\hline Symploca sp. & Belamide A & Antimitotic \\
\hline Lyngbya majuscula & Curacin & $\begin{array}{l}\text { Cytotoxic activity in } \mathrm{H}-460 \text { human lung } \\
\text { carcinoma cells }\end{array}$ \\
\hline $\begin{array}{l}\text { Micromonospora } \\
\text { marina }\end{array}$ & Thiocoraline & DNA-polymerase inhibitor \\
\hline Other & Compound & Mechanism of action \\
\hline $\begin{array}{l}\text { Clavularia viridis (soft } \\
\text { coral) }\end{array}$ & Bromovulone & Activation of caspase 12 \\
\hline Clavularia viridis & Clavulone II & $\begin{array}{l}\text { Induces the disruption of mitochondrial } \\
\text { membrane potential and activates caspases } 8 \text {, } \\
9 \text { and 3; downregulates cyclin D1 expression } \\
\text { and promotes cell cycle arrest in G1 phase }\end{array}$ \\
\hline $\begin{array}{l}\text { Squalus acanthias } \\
\text { (shark) }\end{array}$ & Squalamine & Induces phospholipid bilayer disruption \\
\hline $\begin{array}{l}\text { Bugula neritina } \\
\text { (bryozoans) }\end{array}$ & Bryostatin & Modulator of several protein kinases \\
\hline $\begin{array}{l}\text { Pentacta quadrangulari } \\
\text { (sea cucumber) }\end{array}$ & Philinopside A & Cytotoxic and antiangiogenic \\
\hline Several fungus & Verrucarin A & Protein synthesis inhibitor \\
\hline
\end{tabular}

Table 1. Marine anticancer compounds from several sources and their suggested mechanisms of action (Amador et al., 2003; Simmons et al., 2005; Paleari et al., 2006; Mayer \& Gustafson, 2008; Sánchez et al., 2008; Queiroz et al., 2009; García et al., 2010; Taniguchi et al., 2010).

proliferation and induces apoptosis by inhibiting the insulin-like growth factor 1 receptor signaling and the PI3K/Akt pathway (Know \& Nan, 2007). Sulfated polysaccharides from Caulerpa cupressoides, Caulerpa prolifera, Caulerpa sertularioides and Codium isthmocladum have also been demonstrated to inhibit HeLa cell proliferation (Costa et al., 2010). Sulfated polysaccharides from $L$. saccharina, L. digitata, F. serratus, F. distichus and F. vesiculosus strongly blocked MDA-MB-231 breast carcinoma cell adhesion to platelets, an effect that might have critical implications in tumor metastasis (Cumanshi et al., 2007). In addition, a fucan from Spatoglossum schröederi shows anti-adhesive activity by binding directly to fibronectin (FN), and blocking FN sites that are recognized by cell surface ligands, possibly the integrin family of proteins (Rocha et al., 2005).

The heterofucan from Undaria pinnatifida induces apoptosis in A549 human lung carcinoma cells through downregulation of the antiapoptotic protein Bcl-2 and activation of caspases. This heterofucan also downregulated p38 mitogen-activated potein kinase (p38 MAPK) and PI3K/Akt, while the ERK1/2 pathway was activated (Boo et al., 2011). Additionally, literature reports that fucans are able to induce cell death by mechanisms independent of caspases. For instance, Aisa and colleagues (2005) showed human lymphoma HS-Sultan cell death induced by a fucan from Fucus vesiculosus through activation of the ERK signaling pathway (Aisa et al., 
2005). Hyun and colleagues (2009) also provide evidence that the proapoptotic effect of this fucan is mediated by ERK and p38 MAPK activation, and PI3K/Akt inhibition in HCT-15 colon carcinoma cells (Hyun et al., 2009). Moreover, F. vesiculosus-derived fucan also affected the NFKB pathway (Nakamura et al., 2006). Recently, a heterofucan from Sargassum filipendula induces apoptosis in HeLa cells mainly by the mitochondrial release of apoptosis-inducing factor (AIF) into cytosol. Additionally, in SF-1.5v cells, the expression of Bcl-2 is decreased, in contrast to the increased expression of the apoptogenic protein Bax (Costa et al., 2010).

The marine environment is a major source of anticancer molecules. In recent years, more than 2,000 molecules were found. Here we describe a few with known mechanisms of action. They represent potential candidates for the treatment of malignant disease, either to be used as single agents, or as part of a combination regimen. In addition, they provide a very good tool to discover novel targets, which might be important in the understanding and treatment of chemoresistant cancer. However, there are marine environments that are very poorly studied, as regions below $100 \mathrm{~m}$ depth. Besides this, many marine microorganisms cannot yet be cultivated. These indicate that there are still several marine anticancer agents to be discovered.

\section{Drug design based on natural products}

As highlighted in the above sections, natural products are still major sources of innovative therapeutic agents for cancer, as well as for infectious diseases, lipid disorders and immunomodulation (Cragg et al., 1997; Newman et al., 2003; Butler, 2004; Lee, 2004; Butler, 2005; Newman \& Cragg, 2007). However, the complexity of many natural products as well as the fact that they are present in the nature can limit the scope for making chemical modifications to optimize their therapeutic use. Moreover, obtaining a renewable supply of active compounds from biological sources may be problematic. Despite these barriers, total synthesis of the potent anticancer natural product discodermolide, recently performed in multigram scale (Mickel et al., 2004a; Mickel et al., 2004b; Mickel et al., 2004c; Mickel et al., 2004d; Mickel et al., 2004e), demonstrates that synthetic organic chemistry is a powerful tool for increasing efficiency of natural products of limited supply, those with very complex structures or those that present no biological desired properties (Nicolaou \& Sorensen, 1996; Nicolaou \& Snyder, 2003). In this chapter section, we describe two examples of chemical modifications done in natural products core to improve their activity and/or effectiveness. The molecules in focus are podophyllotoxin and goniothalamin, natural products that exhibit anticancer properties. The former substance was the lead compound for the development of etoposide, teniposide and etopophos, three widely used anticancer drugs, while goniothalamin still have work to do on it to get good clinical effects in vivo. Both molecules exemplify how important is the biodiversity as a source of chemical weapons to fight cancer.

\subsection{Podophyllotoxin: from natural sources to drugs}

Podophyllin, a resin produced by species of the genus Podophyllun (Berberidaceae), is traditionally known to have biological properties such as purgatives, antihelminthic, vesicant, antiproliferative, anti-venereal warts, and anti-cough agents (For excellent reviews of the historical aspects of the podophyllotoxins see: Imbert, 1998; Canel et al., 2000; Gordaliza et al., 2004). The major component of podophyllin, podophyllotoxin (Fig. 1), was isolated from this resin in 1881 by Podwissotzki (Podwyssotzki, 1881 and 1882). Among all biological properties of podophyllotoxin, its antitumor activity is the most explored. 


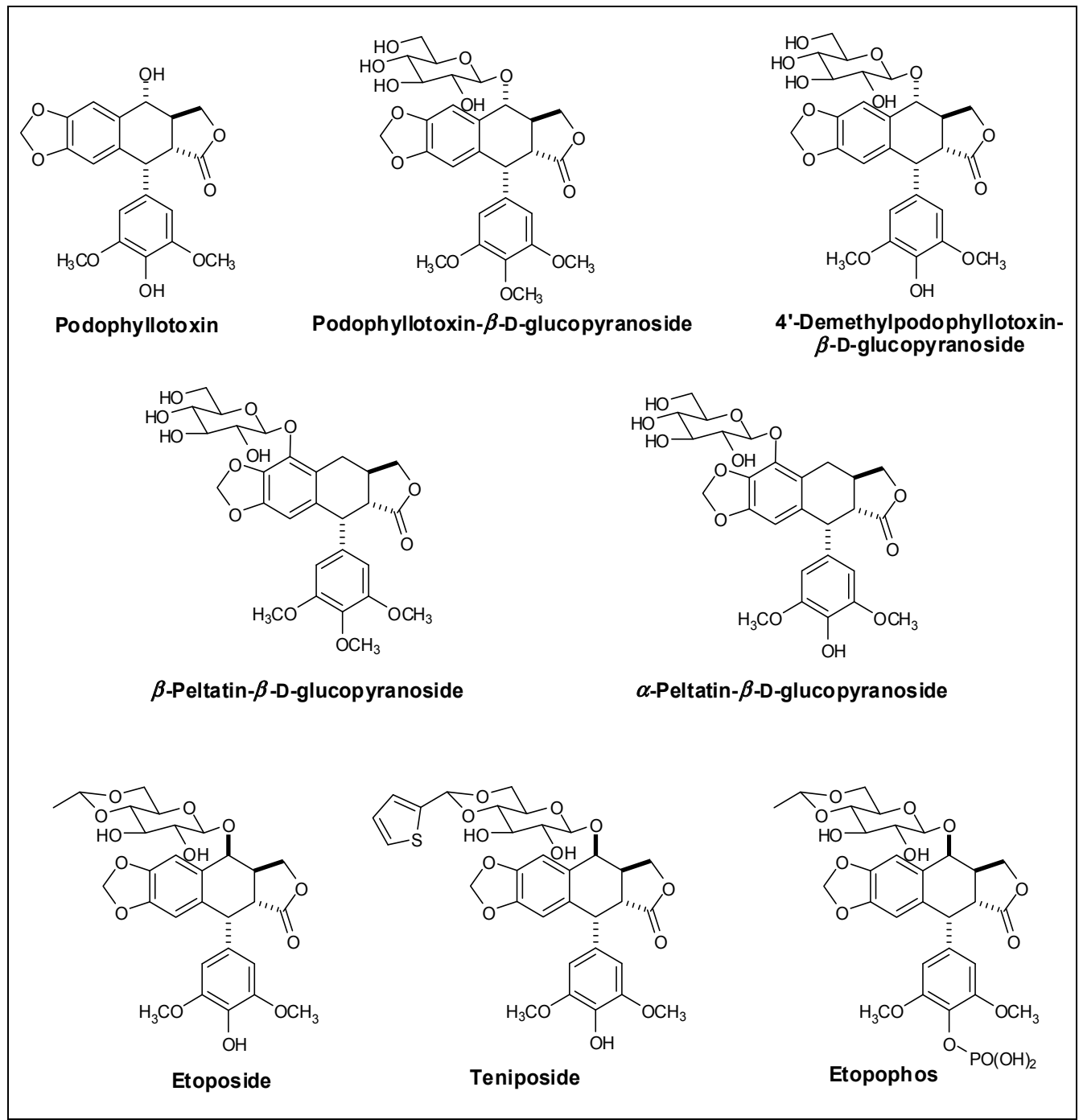

Fig. 1. Structure of podophyllotoxin, glycosides and synthetic derivatives.

Podophyllotoxin is effective in the treatment of Wilms' tumor, genital tumors, non-Hodgkin and other lymphomas, and lung cancer (Utsugi et al., 1996; Subrahmanyam et al., 1998; Liu et al., 2007). However, the gastrointestinal toxicity of this compound was unacceptable (Greenspam et al., 1950; Leiter et al., 1950). Inspired by the potential antitumor activity of podophyllotoxin, the chemists Hartmann F. Stähelin and Albert von Wartburg, working at the Sandoz Company in the mid-1950s, synthesized a large number of podophyllotoxinderivatives aiming to obtain analogues more active, more water soluble and exhibiting less gastrointestinal toxicity (Stähelin \& von Wartburg, 1991; Canel et al., 2000). Their first thought was that glycoside derivatives may be present in the plant and that such derivatives may be less toxic and certainly less hydrophobic than the corresponding aglycones. Indeed, by modifying the procedures of extraction of podophyllin, these chemists were able to isolate four novel glycosides: podophyllotoxin- $\beta$-D-glucopyranoside, $4^{\prime}$ - 
demethylpodophyllotoxin- $\beta$-D-glucopyranoside, $\beta$-peltatin- $\beta$-D-glucopyranoside, $\alpha$-peltatin$\beta$-D-glucopyranoside (Fig. 1) (Stähelin \& von Wartburg, 1991) and these glycosides were more soluble and less toxic. However, the antitumor activities of glycosides were also reduced. Efforts were than directed to chemically modify the glycosides to enhance their cytotoxic activities against cancer cells and from this task force, a range of nearly 600 podophyllotoxin-derivatives were synthesized (Canel et al., 2000).

Two semisynthetic podophyllotoxin-derivatives etoposide and teniposide (Fig. 1), products of condensation of 4 -demethylpodophyllotoxin- $\beta$-D-glucopyranoside with acetaldehyde and 2-thiophenecarboxaldehyde, respectively, showed to have good clinical effects against cancer cells (Stähelin \& von Wartburg, 1991 and cited references). Additionally, etoposide and teniposide, have potent cytotoxicity in several cancer cell lines, including testicular and small cell lung cancer, lung cancer, lymphoma, leukemia and Kaposi's sarcoma; however, they were still less soluble than the corresponding glycoside (Gordaliza et al., 2004). To overcome solubility problems, the Bristol-Myers Squibb Co., Princeton, New Jersey, USA, developed the etoposide phosphate derivative (etopophos ${ }^{\circledR}$ ), which was better suited for intravenous administration. In 1996 the US Food and Drug Administration approved this prodrug for having similar pharmacological and pharmacokinetic profiles of the parent compound, but different solubilities. In fact, the bioavailability in vivo was 1,250-fold increased using this prodrug, which is an important improvement of etoposide formulation (Schacter et al., 1994; Budman, 1996; Greco \& Hainsworth, 1996).

It is noteworthy to mention that the traditional sources of podophyllotoxin as raw material will not attend the increasing demand of this substance to produce their derivatives etoposide, teniposide and etopophos ${ }^{\circledR}$. Currently, approximately 298 clinical trials are under way to test these derivatives for new indications and/or new formulations. Each year more podophyllotoxin-derivatives are synthesized and evaluated as new chemical entities for cancer treatment (Liu et al., 2007). This scenario requires an urgent effort to develop short synthetic routes and/or the use of genetic engineering to manipulate the biosynthetic pathways of podophyllotoxin in order to increase the synthetic and natural sources of an important molecule for human healthy. In summary, podophyllotoxin is a classical example of the importance of biodiversity in furnishing new chemical entities and how powerful is the organic chemistry to increase the efficiency of natural products to get useful drugs to fight cancer.

\subsection{Goniothalamin: a lead compound for drug design?}

Phytochemical studies of the genus Goniothalamus have resulted in the isolation and characterization of many compounds with a variety of biological activities (Blázquez et al., 1999; de Fátima et al., 2006a). The styryl lactones and acetogenins of Annonaceae are a group of secondary metabolites mainly isolated from this genus (Bermejo et al., 2005; de Fátima et al., 2006a). The natural form of goniothalamin [(R)-goniothalamin; Fig. 2] is the styryl lactone most extensively studied and its promising antiproliferative activity have prompted scientists to investigate with more details its potential as antitumor agent (Zhou et al., 2005; de Fátima et al., 2006a and cited references; Dumitrescu et al., 2010; Wach et al., 2010; Vendramini-Costa et al., 2010; Kasaplar et al., 2010). This natural compound displayed in vitro cytotoxic effect especially by inducing apoptosis in different cancer cell lines (Ali et al., 1997; Pihie et al., 1998; Inayat-Hussain et al., 1999; Inayat-Hussain et al., 2003; Chen et al., 2005; de Fátima et al., 2005; Chan et al., 2006; de Fátima et al., 2008b; Inayat-Hussain et al., 2010). This effect was shown to be selective for cancer cell lines with no significant 
cytotoxicity toward non-malignant cells (Pihie et al., 1998; de Fátima et al., 2005 and cited references). In in vivo models, $(R)$-goniothalamin was reported to have tumoricidal and tumoristatic activities in Sprague-Dawley rats with 7,12-dimethylbenzanthracene (DMBA)induced mammary tumors and in Ehrlich solid tumor in mice (Meenakshii et al., 2000; Vendramini-Costa et al., 2010). Although the biological activities exhibited by the natural form of goniothalamin ( $6 R$ absolute configuration) have been widely investigated, no studies about the biological activities of (S)-goniothalamin (Fig. 2) were reported up to 2005 (de Fátima et al., 2006b; Kasaplar et al., 2009). Recently, we have described not only the synthesis, but also the antiproliferative activities of both $(R)$ - and (S)-goniothalamin. Interestingly, we found that $(S)$-goniothalamin $\left(\mathrm{IC}_{50}=6.4 \mu \mathrm{M}\right)$ was 1,600 -fold more potent than $(R)$-goniothalamin $\left(\mathrm{IC}_{50}=4.0 \mathrm{nM}\right)$ in renal 786-0 cancer cells (de Fátima et al., 2006b). As reported for $(R)$-goniothalamin (Pihie et al., 1998; de Fátima et al., 2005 and cited references), we demonstrated that $(S)$-goniothalamin exhibited pronounced selectivity for cancer cells, while presenting minor cytotoxicity against non-tumor cells (de Fátima et al., unpublished results). The extremely high antiproliferative activity and selectivity presented by $(S)$-goniothalamin for $786-0$ cell line $\left(\mathrm{IC}_{50}=4.0 \mathrm{nM}\right)$ prompted us to synthesize eigth analogues (compounds 1-8; Fig. 2) to identify the pharmacophoric groups responsible for this antiproliferative activity.<smiles>O=C1C=CC[C@H](/C=C/c2ccccc2)O1</smiles>

(R)-Goniothalamin (Natural form)<smiles>O=C1CCCC(/C=C/c2ccccc2)O1</smiles>

(1)<smiles>O=C1CCCC(CCc2ccccc2)O1</smiles>

(2)<smiles>O=C1C=CCC(/C=C/c2ccccc2)O1</smiles>

(S)-Goniothalamin<smiles>O=C1C=CCC(CCc2ccccc2)O1</smiles>

(3)<smiles>O=C1C=CCC(/C=C/C2CCCCC2)O1</smiles>

(4)<smiles>O=C1C=CCC(/C=C/c2ccc([N+](=O)[O-])cc2)O1</smiles><smiles>O=C1C=CCC(/C=C/c2ccc(F)cc2)O1</smiles><smiles>COc1ccc(/C=C/C2CC=CC(=O)O2)cc1</smiles>

(7)<smiles>O=C1C=CCC(/C=C/c2ccc3c(c2)OCO3)O1</smiles>

(8)

Fig. 2. Structure of natural goniothalamin and its synthetic analogues.

We found that (S)-goniothalamin was 4,750- and 5,200-fold more potent in inhibiting proliferation of kidney cancer cells (786-0) than analogues $\mathbf{1}$ and 3, respectively (de Fátima et al., 2006b). Remarkably, analogue 4 with a cyclohexyl substituent conserved the same 
cytotoxic activity as (S)-goniothalamin against renal 786-0 cancer cells, being active at the nanomolar level $\left(\mathrm{IC}_{50}=5 \mathrm{nM}\right)$. No antiproliferative activity was found for analogue 2 under our experimental conditions. These results demonstrate that the endo and exo double bonds in the pyranone ring are essential for the activity of (S)-goniothalamin against 786-0 cells. It is noteworthy that analogues 1, 2, and 3 lacking either one or both double bonds had much lower activity than (S)-goniothalamin (de Fátima et al., 2006b). Recently, the importance of the $E$-configuration of the styryl moiety in $(R)$-goniothalamin for its antiproliferative activity was shown (de Fátima et al., 2005) and the $\alpha, \beta$-unsaturated lactone group has already been implicated in the biological activity of other natural lactones such as cytostatin (Bialy \& Waldmann, 2003) and fostriecin (Buck et al., 2003). This behavior is most probably due to its role as a Michael acceptor for nucleophilic amino acid residues (cysteine, lysine, serine or threonine) present in the natural receptors that interact with these compounds (de Fátima et al., 2006b).

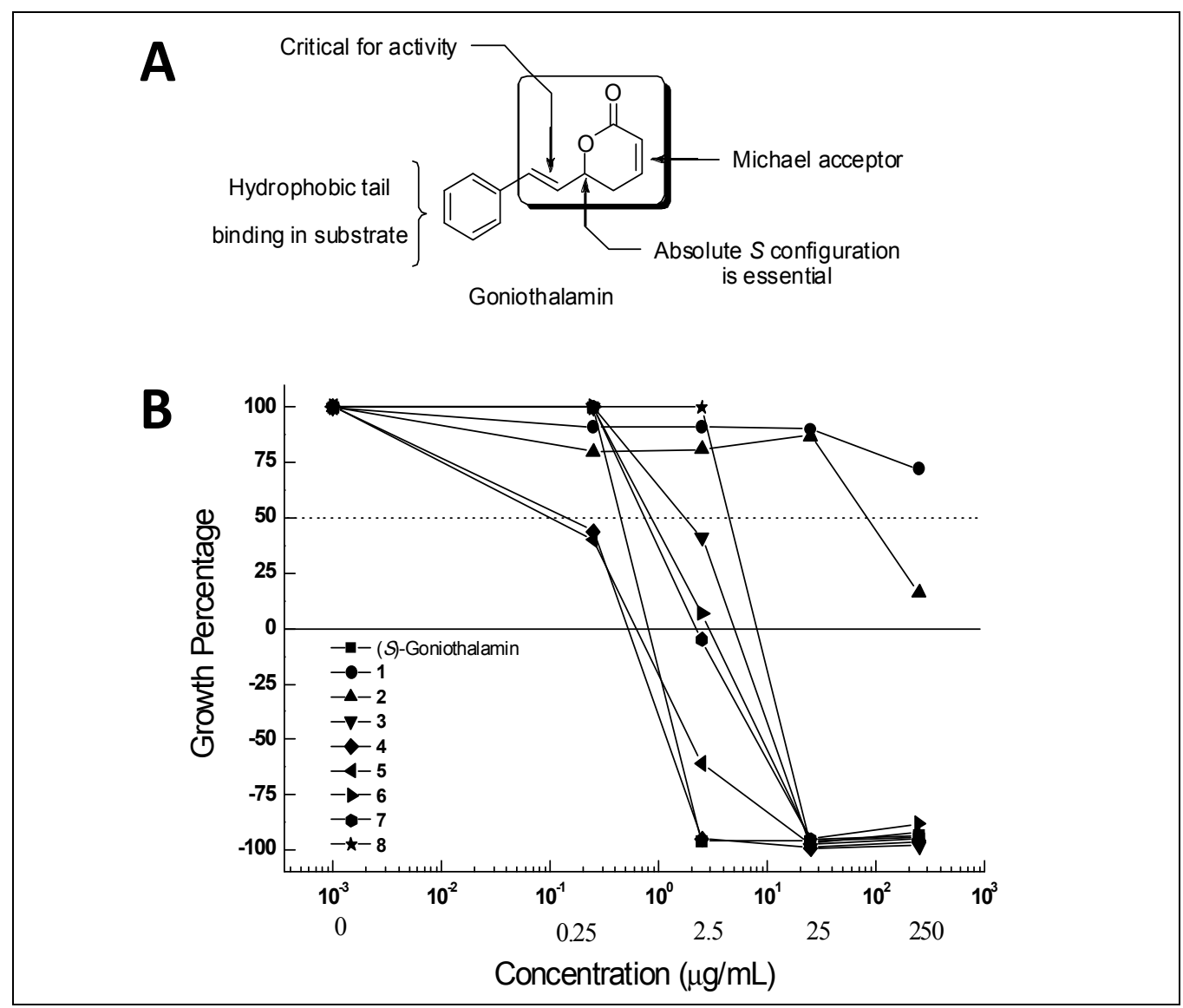

Fig. 3. A: Pharmacophoric groups of goniothalamin identified by the cytotoxicity in renal cancer cell line (786-0); B: Percentage growth of 786- 0 cells after $48 \mathrm{~h}$ of treatment with different concentrations $(0.25,2.5,25$ and $250 \mu \mathrm{g} / \mathrm{mL})$ of $(S)$-goniothalamin and its analogues 1 to 8 . Positive values in relation to y axis correspond to cytostatic activity, while the others refer to the cytotoxic activity of the compound analyzed. 
Interestingly, $(R)$-analogue of $\mathbf{1}$ and $\mathbf{2}$ were shown to be the main metabolites detected and identified in urine and blood samples of $(R)$-goniothalamin-treated Sprague-Dawley rats, thus signaling the double bond reduction in $(R)$-goniothalamin as a potential detoxification route in this species (El-Sharkaway et al., 1996). Moreover, the results obtained from the treatment of renal cancer cells with pyranones 5 to 8 demonstrated that electron-donating or electron-withdrawing groups in the aromatic ring decreased their potency when compared to $(S)$-goniothalamin. Overall, the findings for renal 786-0 cancer cells suggest that aromatic ring or cyclohexyl in (S)-goniothalamin and 4, respectively, likely interacts with a hydrophobic domain of a biomolecule present in the cancer cell since these compounds were shown to be the most active in inhibiting cell proliferation at nanomolar concentrations (de Fátima et al., 2006b). From all these results, we have identified the pharmacophoric groups of goniothalamin as presented in Figure 3.

Goniothalamin represents an interesting example of the different sensitivity of cell lines to enantiomers compounds. Indeed, not only a distinct cytotoxicity profile was described for $(R)$ - and (S)-goniothalamin but also different mechanisms of action were described (de Fátima et al., 2006b; de Fátima et al., 2008). (R)-Goniothalamin caused renal cell death primarily by apoptosis, whereas autophagy was involved in $(S)$-goniothalamin-induced cell death (de Fátima et al., 2008). Again, it is important to point out the importance of both, biodiversity and organic chemistry to increase and modulate the efficiency of natural products to get useful drugs to fight cancer; however, in this particular case, much more information is necessary to have a goniothalamin-derivative as a useful drug in cancer chemotherapy. Finally, the studies performed until now clearly demonstrate that goniothalamin is indeed a lead compound for drug discovery from natural sources.

Besides the molecules cited here, many other interesting natural products are suitable as lead compounds for the design of new drugs (Koehn \& Carter, 2005; Gullo et al., 2006; Gordaliza, 2007; Lam, 2007; Molinski et al., 2009), such as curcumin, riboflavin, resveratrol, and caffeic acid (Aggarwal et al., 2003; Kaminaga et al., 2003; Aggarwal et al., 2004; de Souza et al., 2005).

\section{Conclusion}

The potential of nature as a primary source for anticancer drug discovery is astonishing, since it offers an unlimited structural diversity of molecular models for bioprospection unmatched by any synthetic chemical collection or combinatorial chemistry approach. Furthermore, natural products are invaluable as tools for identification of exploitable molecular targets and as templates for exploring novel molecular diversity by structural modification or by the synthesis of new designed compounds. This not only provides a plenty and renewable supply of starting materials for screening, but also contributes to improve current libraries with new lead generations. Furthermore, expansions in the fields of chemistry and biology have guided new drug discovery strategies to maximize the identification of pharmacologically relevant natural product structures. In this context, the recent approval of ixabepilone, trabectedin and temsirolimus for cancer treatment (Bailly, 2009) illustrates the important contribution of natural products, mainly from microbial sources, in oncology, even with the increasing use of molecular target-based therapy. Therefore, a cooperative interdisciplinary action on modern drug discovery approaches, driven by biodiversity, genomic and chemical rationales is emerging with the optimism that examining new natural products will continue to turn up useful drugs to treat cancer. In this 
scenario, Brazilian biodiversity made this country a unique source of leads and structural templates from which new therapeutic agents may be developed. Indeed, with so much terrestrial and marine diversity awaiting exploration, the Brazilian territory constitutes a true treasure for the discovery of new anticancer drugs, providing a further stimulus to the preservation of the precious ecosystem where these "golden molecules" can be found.

\section{Acknowledgment}

Our research on this field is supported by Fundação de Amparo à Pesquisa do Estado de São Paulo (FAPESP), Fundação de Amparo à Pesquisa do Estado de Minas Gerais (FAPEMIG), Coordenação de Aperfeiçoamento de Pessoal de Nível Superior (CAPES) and Conselho Nacional de Desenvolvimento Científico e Tecnológico (CNPq).

\section{References}

Aisa, Y.; Miyakawa, Y.; Nakazato, T.; Shibata, H.; Saito, K.; Ikeda, Y. \& Kizaki, M. (2005). Fucoidan induces apoptosis of human HS-sultan cells accompanied by activation of caspase-3 and down-regulation of ERK pathways. American Journal of Hematology, Vol.78, No.1, (January 2005), pp. 7-14, ISSN 0361-8609

Aggarwal, B. B.; Kumar, A. \& Bharti, A. C. (2003). Anticancer potential of curcumin: preclinical and clinical studies. Anticancer Research, Vol.23, No.1A, (JanuaryFebruary 2003), pp. 363-398, ISSN 0250-7005

Aggarwal, B. B.; Bhardwaj, A.; Aggarwal, R. S.; Seeram, N. P.; Shishodia, S. \& Takada, Y. (2004). Role of resveratrol in prevention and therapy of cancer: preclinical and clinical studies. Anticancer Research, Vol.24, No.5A, (September-October 2004), pp. 2783-2840, ISSN 0250-7005

Agrawal, D. K. \& Mishra, P. K. (2010). Curcumin and its analogues: potential anticancer agents. Medicinal Research Reviews, Vol.30, No.5, (September 2010), pp. 818-60, ISSN 0198-6325

Ali, A. M.; Mckeen, M. M.; Hamid, M.; Aun, Q. B.; Zauyah, Y.; Azimahtol, H. L. P. \& Kawazu, K. (1997). Cytotoxicity and eletron microscopy of cell death induced by goniothalamin. Planta Medica, Vol.63, No.1, (February 1997), pp. 81-83, ISSN 14390221

Amador, M. L.; Jimeno, J.; Paz-Ares L.; Cortes-Funes, H. \& Hidalgo, M. (2003). Progress in the development and acquisition of anticancer agents from marine sources. Annals of Oncology, Vol.14, No.11, (November 2003), pp. 1607-1615, ISSN 1569-8041

Andreu, D.; Merrifield, R. B.; Steiner, H. \& Boman, H. G. (1985). N-terminal analogues of cecropin A: synthesis, antibacterial activity, and conformational properties. Biochemistry, Vol.24, No.7, (March 1985), pp. 1683-1688, ISSN 0006-2960

Aoki, S.; Chen, Z. S.; Higasiyama, K.; Setiawan, A.; Akiyama, S. \& Kobayashi, M. (2001). Reversing effect of agosterol A, a spongean sterol acetate, on multidrug resistance in human carcinoma cells. Japanese Journal of Cancer Research, Vol.92, No.8, (August 2001), pp. 886-895, ISSN 0910-5050

Arora, A. S.; de Groen, P. C.; Croall, D. E.; Emori, Y. \& Gores, G. J. (1996). Hepatocellular carcinoma cells resist necrosis during anoxia by preventing phospholipasemediated calpain activation. Journal of Cellular Physiology, Vol.167, (June 1996), pp. 434-442, ISSN 1097-4652 
Bai, X.; Cerimele, F.; Ushio-Fukai, M.; Waqas, M.; Campbell, P. M.; Govindarajan, B.; Der, C. J.; Battle, T.; Frank, D. A.; Ye, K.; Murad, E.; Dubiel, W.; Soff, G. \& Arbiser, J. L. (2003). Honokiol, a small molecular weight natural product, inhibits angiogenesis in vitro and tumor growth in vivo. Journal of Biological Chemistry, Vol.278, No.37, (September 2003), pp. 35501-35507, ISSN 1083-351X

Bailly, C. (2009). Ready for a comeback of natural products in oncology. Biochemical Pharmacology, Vol.77, No.9, (May 2009), pp. 1447-1457, ISSN 0006-2952

Balunas, M. J. \& Kinghorn, A. D. (2005). Drug discovery from medicinal plants. Life Sciences, Vol.78, No.5, (December 2005), pp. 431-441, ISSN 0024-3205

Barile, M. F. \& Leventhal, B. G. (1968). Possible mechanism for Mycoplasma inhibition of lymphocyte transformation induced by phytohaemagglutinin. Nature, Vol.17, No.219, (August 1968), pp. 750-752, ISSN 0028-0836

Basavarajappa, B. S. \& Gowda, T. V. (1992). Comparative characterization of two toxic phospholipases A2 from Indian cobra (Naja naja naja) venom. Toxicon, Vol.30, No.10, (October 1992), pp. 1227-1238, ISSN: 0041-0101

Bermejo A.; Figadère B.; Zafra-Polo M. C.; Barrachina I.; Estornell E. \& Cortes D. (2005). Acetogenins from Annonaceae: recent progress in isolation, synthesis and mechanism of action. Natural Products Reports, Vol.22, No.2, (March 2005), pp. 269303, ISSN 1460-4752

Bernardes, N.; Seruca, R.; Chakrabarty, A. M. \& Fialho, A. M. (2010). Microbial-based therapy of cancer: Current progress and future prospects. Bioengineering Bugs, Vol.1, No.3, (May 2010), pp. 178-190. ISSN 1949-1026

Bernheimer, A. W.; Linder, R.; Weinstein, S. A. \& Kim., K. S. (1987). Isolation and characterization of a phospholipase B from venom of Collett's snake. Pseudechis colletti. Toxicon, Vol.25, No.5, pp. 547-555, ISSN: 0041-0101

Beutler, J. A. (2011). Review of the epothilones: an outstanding family of anti-tumor agents. From soil to the clinic. Journal of Natural Products, Vol.2, (March 2011), pp. n.d., ISSN 1520-6025

Bialy, L. \& Waldmann, H. (2003). Synthesis and biological evaluation of cytostatin analogues. Chemical Communication, Vol.7, No.15, (August 2003), pp. 1872-1873, ISSN 1364-548X

Blázquez M. A. ; Bermejo A. ; Zafra-Polo M. C. \& Cortes D. (1999). Styryl-Lactones from Goniothalamus species - A review. Phytochemical Analysis, Vol.10, No.4, (July-August 1999), pp. 161-170, ISSN 1099-1565

Boo, H. J.; Hyun, J. H.; Kim, S. C.; Kang, J. I.; Kim, M. K.; Kim, S. Y.; Cho, H.; Yoo, E. S. \& Kang, H. K. (2011). Fucoidan from Undaria pinnatifida induces apoptosis in A549 human lung carcinoma cells. Phytotherapy Research, doi10.1002/ptr.3489, (March 2011), ISSN 1099-1573

Boots, A. W. ; Haene, G. R. \& Bast, A. (2008). Health effects of quercetin: from antioxidant to nutraceutical. European Journal of Pharmacology, Vol.585, No.2-3, (May 2008), pp. 325-37, ISSN 0014-2999

Braganca, B. M. \& Khandeparker, V. G. (1966). Phospholipase C activity of cobra venom and lysis of Yoshida sarcoma cells. Life Sciences, Vol.5, N0.20, (October 1966), pp. 19111920, ISSN 0024-3205

Bromberg, N.; Dreyfuss, J. L.; Regatieri, C. V.; Palladino, M. V.; Durán, N.; Nader, H. B.; Haun, M. \& Justo G. Z. (2010). Growth inhibition and pro-apoptotic activity of violacein in Ehrlich ascites tumor. Chemico-Biological Interaction, Vol.186, No.1, (June 2010), pp. 43-52, ISSN 0009-279 
Bromberg, N.; Justo, G. Z.; Haun, M.; Durán, N. \& Ferreira, C. V. (2005). Violacein cytotoxicity on human blood lymphocytes and effect on phosphatases. Journal of Enzyme Inhibition and Medicinal Chemistry, Vol.20, No.5, (October 2005), pp. 449-454, ISSN 1475-6366

Bubien, J. K.; Ji, H. L.; Gillespie, G. Y.; Fuller, C. M.; Markert, J. M.; Mapstone, T. B. \& Benos, D. J. (2004). Cation selectivity and inhibition of malignant glioma $\mathrm{Na}^{+}$channels by Psalmotoxin 1. American Journal of Physiology. Cell Physiology, Vol.287, No.5, (November 2004), pp. C1282-C1291, ISSN 1522-1563

Buck, S. B.; Hardouin, C.; Ichikawa, S.; Soenen, D. R.; Gauss, C. M.; Hwang, I.; Swingle, M. R.; Bonness, K. M.; Honkanen, R. E. \& Boger, D. L. (2003). Fundamental role of the fostriecin unsaturated lactone and implications for selective protein phosphatase inhibition. Journal of the American Chemical Society, Vol.125. No.151, (December 2003), pp. 15694-15695, ISSN 1520-5126

Budman, D. R. (1996). Early Studies of Etoposide Phosphate, a Water Prodrug. Seminars in Oncology, Vol.23, Suppl.13, (December 1996), pp. 8-14, ISSN 0093-7754

Butler, M. S. (2004). The role of natural chemistry in drug discovery. Journal of Natural Products, Vol.67, No.2, (November 2004), pp. 2141-2153, ISSN 1520-6025

Butler, M. S. (2005). Natural products to drugs: natural products derived compounds in clinical trials. Natural Produts Reports, Vol.22 (December 2004), pp.162-195, ISSN $1460-4752$

Camargo, C. A. ; da Silva, M. E. ; da Silva, R. A. ; Justo, G. Z. ; Gomes-Marcondes, M. C. \& Aoyama, H. (2011). Inhibition of tumor growth by quercetin with increase of survival and prevention of cachexia in Walker 256 tumor-bearing rats. Biochemical and Biophysical Research Communications, Vol.406, No.4, (March 2011), pp. 638-642, ISSN 0006-291X

Canel, C.; Moraes, R. M. ; Dayan, F. E. \& Ferreira, D. (2000). Podophyllotoxin. Phytochemistry, Vol.54, No.2, (May 2000), pp. 115-120, ISSN 0031-9422

Chan, K. M. ; Rajab, N. F. ; Ishak, M. H. A. ; Ali, A. M.; Yusoff, K.; Din, L. B. \& InayatHussain, S. H. (2006). Goniothalamin Induces Apoptosis in Vascular Smooth Cells. Chemico-Biological Interactions, Vol.159, No.2, (February 2006), pp. 129-140, ISSN 0009-2797

Chaudhari, A.; Mahfouz, M.; Fialho, A. M.; Yamada, T.; Granja, A. T.; Zhu, Y.; Hashimoto, W.; Schlarb-Ridley, B.; Cho, W.; Das Gupta, T. K. \& Chakrabarty, A. M. (2007). Cupredoxin-cancer interrelationship: azurin binding with EphB2, interference in EphB2 tyrosine phosphorylation, and inhibition of cancer growth. Biochemistry, Vol.46, No.7, (February 2007), pp. 1799-1810, ISSN 0006-2960

Chen, H. M.; Wang, W.; Smith, D. \& Chan, S. C. (1997). Effects of the anti-bacterial peptide cecropin B and its analogs, cecropins B-1 and B-2, on liposomes, bacteria, and cancer cells. Biochimica et Biophysica Acta, Vol.1336, No.2, (August 1997), pp. 171179, ISSN 0006-3002

Chen, Y.; Xiang, J.; Gu, W. \& Xu, M. (1998). Chemical constituents of Bufo siccus. Zhongguo Zhong Yao Za Zhi, Vol.23, No.10, (October 1998), pp. 620-640, ISSN 1001-5302

Chen, W. Y.; Wu, C. C.; Lan, Y. H.; Chang, F. R.; Teng, C. M. \& Wu, Y. C. (2005). Goniothalamin induces cell cycle-specific apoptosis by modulating the redox status in MDA-MB-231 cells. European Journal of Pharmacology, Vol.522, No.1-3, (October 2005), pp. 20-29, ISSN 0014-2999

Christensen, S. B.; Skytte, D. M.; Denmeade, S. R.; Dionne, C.; Møller, J. V.; Nissen, P. \& Isaacs, J. T. (2009). A trojan horse in drug development: targeting of thapsigargins 
towards prostate cancer cells. Anticancer Agents in Medicinal Chemistry, Vol. 9, No.3, (March 2009), pp. 276-294, ISSN 1871-5206

Corzo, G.; Villegas, E.; Gomez-Lagunas, F.; Possani, L. D.; Belokoneva, O. S. \& Nakajima, T. (2002). Oxyopinins, large amphipathic peptides isolated from the venom of the wolf spider Oxyopes kitabensis with cytolytic properties and positive insecticidal cooperativity with spider neurotoxins. Journal of Biological Chemistry, Vol.277, No.26, (June 2002), pp. 23627-23637, ISSN 1083-351X

Costa, L. S.; Fidelis, G. P.; Cordeiro, S. L.; Oliveira, R. M.; Sabry, D. A.; Camara, R. B. G.; Nobre, L. T. D. B.; Costa, M. S. S. P.; Almeida-Lima, J.; Farias, E. H. C.; Leite, E. L. \& Rocha, H. A. O. (2010). Biological activities of sulfated polysaccharides from tropical seaweeds. Biomedicine E Pharmacotherapy, Vol.64, No.1, (January 2010), pp. 21-28, ISSN 0753-3322

Crabb, S. J.; Howell, M.; Rogers, H.; Ishfaq, M.; Yurek-George, A.; Carey, K.; Pickering, B. M.; East, P.; Mitter, R.; Maeda, S.; Johnson, P. W.; Townsend, P.; Shinya, K.; Yoshida, M.; Ganesan, A. \& Packham, G. (2008). Characterisation of the in vitro activity of the depsipeptide histone deacetylase inhibitor spiruchostatin A. Biochemical Pharmacology, Vol.76, No.4, (August 2008), pp. 463-475, ISSN 0006-2952

Cragg, G. M. \& Newman, D. (2005). Plants as a source of anti-cancer agents. Journal of Ethnopharmacology, Vol.100, No.1\&2, (August 2005), pp. 72-79, ISSN 0378-8741

Cragg, G. M.; Newman, D. \& Snader, K. M. (1997). Natural products in drug discovery and development. Journal of Natural Products, Vol.60, No.1, (January 1997), pp. 52-60, ISSN 1520-6025

Cumashi, A.; Ushakova, N. A.; Preobrazhenskaya, M. E.; D’Incecco, A.; Piccoli, A.; Totani, L.; Tinari, N.; Morozevich, G. E.; Berman, A. E.; Bilan, M. I.; Usov, A. I.; Ustyuzhanina, N. E.; Grachev, A.; Sanderson, C. J.; Kelly, M.; Rabinovich, G. A.; Iacobelli, S. \& Nifantiev, N. E. (2007). A comparative study of the antiinflammatory, anticoagulant, antiangiogenic, and antiadhesive activities of nine different fucoidans from brown seaweeds. Glycobiology, Vol.17, No.5, (May 2007), pp. 541-552, ISSN 0959-6658

Daniele, J. J.; Bianco, I. D.; Delgado, C.; Briones, C. D. \& Fidelio, G. D. (1997). A new PLA2 isoform isolated from Bothrops neuwiedie (Yaraca chica) venom with novel kinetic and chromatographic properties. Toxicon, Vol.35, No.8, (August 1997), pp. 1205, ISSN 0041-0101

Das, K.; Butler, G. H.; Kwiatkowski, V.; Clark, A. D. Jr.; Yadav, P. \& Arnold, E. (2004). Crystal structures of arginine deaminase with covalent reaction intermediates: implications for catalytic mechanism. Structure, Vol.12, No.4, (April 2004), pp. 657667, ISSN 0969-2126

de Fátima, A.; Kohn, L. K.; Antônio, M. A.; de Carvalho, J. E. \& Pilli, R. A. (2005). (R)Goniothalamin: total synthesis and cytotoxic activity against cancer cell lines. Bioorganic \& Medicinal Chemistry, Vol.13, No.8, (April 2005), pp. 2927-2933, ISSN 1464-3391

de Fátima, A.; Kohn, L. K.; de Carvalho, J.E. \& Pilli, R. A. (2006b). Cytotoxic activity of (S)goniothalamin against human cancer cells. Bioorganic \& Medicinal Chemistry, Vol.14, No.3, (February 2006), pp. 622-631, ISSN 1464-3391

de Fátima, A.; Modolo, L. V.; Conegero, L. S.; Pilli, R. A.; Ferreira, C. V.; Kohn, L. K. \& de Carvalho, J. E. (2006a). Styryl lactones and their derivatives: biological activities, mechanism of action and potential leads for drug design. Current Medicinal Chemistry, Vol.13, No.8, pp. 3371-3384, ISSN 0929-8673 
de Fatima, A.; Modolo, L. V.; Neres, A. T. M.; Ferreira, C. V. \& de Souza, A. C. S. (2008a). Curcumin conjugates and metallocomplexes as lead compounds for development of anticancer agents - a short review. Current Bioactive Compounds, Vol.4, No.3, (October 2008), pp. 189-199, ISSN 1573-4072

de Fátima, A.; Zambuzzi, W. F.; Modolo, L. V.; Tarsitano, C. A. B.; Gadelha, F. R.; Hyslop, S.; de Carvalho, J. E.; Salgado, I.; Ferreira, C. V. \& Pilli, R. A. (2008b). Cytotoxicity of goniothalamin enantiomers in renal cancer cells: involvement of nitric oxide, apoptosis and autophagy. Chemico-Biology Interactions, Vol.176, No.2\&3, (November 2008), pp. 143-150, ISSN 0009-2797

de Souza, A. C.; Ferreira, C. V.; Jucá, M. B.; Aoyama, H.; Cavagis, A. D. M. \& Peppelenbosch, M. P. (2005). Riboflavina: uma vitamina multifuncional. Quimica Nova, Vol.28, No.5, (April 2005), pp.887-891, ISSN 0100-4042

de Souza, A. C.; Kodach, L.; Gadelha, F. R.; Bos, C. L.; Cavagis, A. D.; Aoyama, H.; Peppelenbosch, M. P. \& Ferreira, C. V. (2006). A promising action of riboflavin as a mediator of leukaemia cell death. Apoptosis, Vol.11, No.10, (October 2006), pp. 17611771, ISSN 1573-675X

de Souza Queiroz, K. C.; Zambuzzi, W. F.; Santos de Souza, A. C.; da Silva, R. A.; Machado, D.; Justo, G. Z.; Carvalho, H. F.; Peppelenbosch, M. P. \& Ferreira, C. V. (2007). A possible anti-proliferative and anti-metastatic effect of irradiated riboflavin in solid tumours. Cancer Letters, Vol.258, No.1, (December 2007), pp. 126-134, ISSN 15737217

Demain, A. L. (2009). Antibiotics: natural products essential for human health. Medical Research Reviews, Vol.29, No.6, (November 2009), pp. 821-841, ISSN 1098-1128

Deshane, J.; Garner, C. C. \& Sontheimer, H. (2003). Chlorotoxin inhibits glioma cell invasion via matrix metalloproteinase-2. Journal of Biological Chemistry, Vol.278, No.6, (February 2003), pp. 4135-4144, ISSN 1083-351X

Dumitrescu, L.; Huong, D. T. M.; Hung, N. V. \& Crousse, B. (2010). Synthesis and cytotoxic activity of fluorinated analogues of Goniothalamus lactones. Impact of fluorine on oxidative process. European Journal of Medicinal Chemistry, Vol.45, No. 7, (July 2010), pp. 3213-3218, ISSN 0223-5234

Durán, N.; Justo, G. Z.; Ferreira, C. V.; Melo, P. S.; Cordi, L. \& Martins, D. (2007). Violacein: properties and biological activities. Biotechnology \& Applied Biochemistry, Vol.48, Pt.3, (November 2007), pp. 127-133, ISSN 0885-4513

El-Sayed A. S. (2010). Microbial L-methioninase: production, molecular characterization, and therapeutic applications. Applied Microbiology Biotechnology, Vol.86, No.2, (March 2010), pp. 445-467, ISSN 1432-0614

El-Sharkawy, S.; Yusuf, Z.; Pihie, A. H. \& Ali, A. M. (1996). Metabolism of goniothalamin in animal and microbial system. Bollettino Chimico Farmaceutico, Vol.135, No.1, (January 1996), pp. 35-40, ISSN 0006-6648

Escoubas, P.; De Weille, J.R.; Lecoq, A.; Diochot, S.; Waldmann, R.; Champigny, G.; Moinier, D.; Ménez, A. \& Lazdunski, M. (2000). Isolation of a tarantula toxin specific for a class of proton-gated $\mathrm{Na}^{+}$channels. Journal of Biological Chemistry, Vol.275, No.33, (August 2000), pp. 25116-25121, ISSN 1083-351X

Ferreira, C. V.; Bos, C. L.; Versteeg, H. H.; Justo, G. Z.; Durán, N. \& Peppelenbosch M. P. (2004). Molecular mechanism of violacein-mediated human leukemia cell death. Blood, Vol.104, No.5, (September 2004), pp. 1459-1464, ISSN 0006-4971 
Fortner, K. C.; Kato, D.; Tanaka, Y. \& Shair, M. D. (2010). Enantioselective synthesis of (+)cephalostatin 1. Journal of the American Chemical Society, Vol.132, No.1, (January 2010), pp. 275280, ISSN 0002-7863

Fujiwara, Y.; Mangetsu, M.; Yang, P.; Kofujita, H.; Suzuki, K.; Ohfune, Y. \& Shinada, T. (2008). A quinone isolated from the nest of Vespa simillima and its growth-inhibitory effect on rat liver cancer cells. Biological \& Pharmaceutical Bulletin, Vol.31, No.4, (April 2008), pp. 722-725, ISSN 0918-6158

Galeano, E.; Rojas, J. J. \& Martínez, A. (2011). Pharmacological developments obtained from marine natural products and current pipeline perspective. Natural Products Communications, Vol.6, No.2, (February 2011), pp. 287-300, ISSN 1555-9475

García, J.; Franci, G.; Pereira, R.; Benedetti, R.; Nebbioso, A.; Rodríguez-Barrios, F.; Gronemeyer, H.; Altucci, L. \& Lera, A. R. (2010). Epigenetic profiling of the antitumor natural product psammaplin A and its analogues. Bioorganic $\mathcal{E}$ Medicinal Chemistry, doi:10.1016/j.bmc.2010.12.026, (December 2010), ISSN 0968-0896

Ghantous, A.; Gali-Muhtasib, H.; Vuorela, H.; Saliba, N. A. \& Darwiche N. (2010). What made sesquiterpene lactones reach cancer clinical trials? Drug Discovery Today, Vol.15, No. 15-16, (August 2010), pp. 668-678, ISSN 1359-6446

Ghavami, S.; Asoodeh, A.; Klonisch, T.; Halayko, A. J.; Kadkhoda, K.; Kroczak, T. J.; Gibson, S. B.; Booy, E. P.; Naderi-Manesh, H. \& Los, M. (2008). Brevinin-2R(1) semiselectively kills cancer cells by a distinct mechanism, which involves the lysosomalmitochondrial death pathway. Journal of Cellular and Molecular Medicine, Vol.12, No.3, (June 2008), pp. 1005-1022, ISSN 1582-4934

Giri, B.; \& Gomes, A. (2004). Antineoplastic activity of Indian toad (Bufo melanostictus, Schneider) skin extract on EAC cells and Human leukemic (U937 and HL60) cell line, Indian Journal of Pharmacology, Vol.36, (December 2004), pp. S83, ISSN 19983751

Giri, B.; Gomes, A.; Debnath, A.; Saha, A.; Biswas, A. K.; Dasgupta, S. C. \& Gomes, A. (2006). Antiproliferative, cytotoxic and apoptogenic activity of Indian toad (Bufo melanostictus, Schneider) skin extract on U937 and K562 cells. Toxicon, Vol.48, No.4, (September 2006), pp. 388-400, ISSN 0041-0101

Girisk, K. S. \& Kemparaju, K. (2007). The magic glue hyaluronan and its eraser hyaluronidase: a biological overview. Life Sciences, Vol.80, No.21, (May 2007), pp. 921-943, ISSN 0024-3205

Gomes, A.; Bhattacharjee, P.; Mishra, R.; Biswas, A. K.; Dasgupta, S. C. \& Giri, B. (2010). Anticancer potential of animal venoms and toxins. Indian Journal of Experimental Biology, Vol.48, No.2, (February 2010), pp. 93-103, ISSN 0019-5189

Goudet, C.; Chi, C. W. \& Tytgat, J. (2002). An overview of toxins and genes from the venom of the Asian scorpion Buthus martensi Karsch. Toxicon, Vol. 40, No.9, (September 2002), pp. 1239-1258, ISSN 0041-0101

Gouveia, A. I. C. B.; Silveira, R. B.; Nader, H. B.; Dietrich, C. P.; Gremski, W.; Veiga, S. S. (2005). Identification and partial characterization of hyaluronidades in Lonomia obliqua venom. Toxicon, Vol.45, No.4, (March 2005), pp. 403-410, ISSN 0041-0101

Gordaliza, M. (2007). Natural products as lead to anticancer drugs. Clinical and Translational Oncology, Vol.9, No.12, (December 2007), pp. 767-776, ISSN 1699-3055

Gordaliza, M.; García, P. A.; del-Corral, J. M. M.; Castro, M. A. \& Gómez-Zurita, M. A. (2004). Podophyllotoxin: distribution, sources, applications and new cytotoxic derivatives. Toxicon, Vol.44, No.4, (September 2004), pp. 441-459, ISSN 0041-0101 
Greco, F. A. \& Hainsworth, J. D. (1996). Clinical studies of etoposide phosphate. Seminars in Oncology, Vol.23, No.6, Suppl.13, (December 1996), pp. 45-50, ISSN 0093-7754

Greenspan, E.; Lester, J. \& Shear, M. (1950). Effect of alpha-peltatin, beta-peltatin and podophyllotoxin on lymphoma and other transplanted tumors. Journal of the National Cancer Institute, Vol.10, No.6, (June 1950), pp. 1295-1333, ISSN 0027-8874

Gopal, Y. N.; Chanchorn, E. \& Van Dyke M. W. (2009). Parthenolide promotes the ubiquitination of MDM2 and activates p53 cellular functions. Molecular Cancer Therapy, Vol.8, No.3, (March 2009), pp. 552-562, ISSN 1535-7163

Gullo ,V. P.; McAlpine, J.; Lam, K. S.; Baker, D. \& Peterson, F. (2006). Drug discovery from natural products. Journal of Industrial Microbiology and Biotechnology, Vol.33, No.7, (March 2006), pp. 523-531, ISSN 1476-5535

Harvey, A. (2010). The role of natural products in drug discovery and development in the new millennium. IDrugs, Vol.13, No.2, (February 2010), pp. 70-72, ISSN 1369-7056

Heinen, T.E. \& da Veiga, A. B. (2011). Arthropod venoms and cancer. Toxicon, Vol.57, No.4, (March 2011), pp. 497-511, ISSN 0041-0101

Hemalswarya, S. \& Doble, M. (2006). Potential synergism of natural products in the treatment of cancer. Phytotherapy Research, Vol.20, No.4, (April 2006), pp. 239-349, ISSN 0951-418X

Hyun, J. H.; Kim, S. C.; Kang, J. I.; Kim, M. K.; Boo, H. J.; Kwon, J. M.; Koh, Y. S.; Hyun, J. W.; Park, D. B.; Yoo, E. S. \& Kang, H. K. (2009). Apoptosis inducing activity of fucoidan in HCT-15 colon carcinoma cells. Biological \& Pharmaceutical Bulletin, Vol.32, No.10, (October 2009), pp. 1760-1764, ISSN 1760-1764

Imbert, T. F. (1998) Discovery of podophyllotoxins. Biochimie, Vol.80, No.2, (March 1998), pp. 207-222, ISSN 0300-9084

Inayat-Hussain, S. H.; Annuar, B. O.; Din, L. B.; Ali, A. M. \& Ross, D. (2003). Loss of mitochondrial transmembrane potential and caspase- 9 activation during apoptosis induced by the novel styryl-lactone goniothalamin in HL-60 leukemia cells. Toxicology in Vitro, Vol.17, No.4, (August 2003), pp. 433-439, ISSN 0887-2333

Inayat-Hussain, S. H.; Chan, K. M.; Rajab, N. F.; Din, L. B.; Chow, S. C.; Kizilors, A.; Farzaneh, F. \& Williams, G. T. (2010). Goniothalamin-induced oxidative stress, dna damage and apoptosis via caspases-2 independent and Bcl-2 independent pathways in Jurkat T-cells. Toxicology Letters, Vol.193, No.4, (March 2010), pp. 108-114, ISSN 0378-4274

Inayat-Hussain, S. H.; Osman, A. B.; Din, L. B.; Ali, A. M.; Snowden, R. T.; MacFarlane, M. \& Cain, K. (1999). Caspases-3 and -7 Activated in goniothalamin-induced apoptosis in human Jurkat T-cells. FEBS Letters, Vol.456, No.3, (August 1999), pp. 379-383, ISSN 0014-5793

Iwasaki, S. \& Omura, S. (2007). Search for protein farnesyltransferase inhibitors of microbial origin: our strategy and results as well as the results obtained by other groups.The Journal of Antibiotics (Tokyo), Vol.60, No.1, (January 2007), pp.1-12, ISSN 0021-8820

Jiao, G.; Yu, G.; Zhang, J. \& Ewart, H. S. (2011). Chemical structures and bioactivities of sulfated polysaccharides from marine algae. Marine Drugs, Vol.9, No.2, (February 2011), pp. 196-223, ISSN 1660-3397

Justo, G. Z. \& Ferreira, C. V. (2005). Coagulation and cancer therapy: the potential of natural compounds. Current Genomics, Vol.6, No. n.d., pp. 461-469, ISSN 1389-2029

Kamano, Y.; Kotake, A.; Hashima, H.; Inoue, M.; Morita, H.; Takeya, K.; Itokawa, H.; Nandachi, N.; Segawa, T.; Yukita, A.; Saitou, K.; Katsuyama, M. \& Pettit, G. R. (1998). Structure-cytotoxic activity relationship for the toad poison bufadienolides. 
Bioorganic \& Medicinal Chemistry, Vol.6, No.7, (July 1998), pp. 1103-115, ISSN 09680896

Kaminaga, Y.; Nagatsu, A.; Akiyama, T.; Sugimoto N.; Yamazaki, T.; Maitani, T. \& Mizukami, H. (2003). Production of unnatural glucosides of curcumin with drastically enhanced water solubility by cell suspension cultures of Catharanthus roseus. FEBS Letters, Vol.555, No.2, (December 2003), pp. 311-316, ISSN 0014-5793

Kang, I. C.; Lee, Y. D. \& Kim, D. S. (1999). A novel disintegrin salmosin inhibits tumor angiogenesis. Cancer Research, Vol.59, No.15, (August 1999), pp. 3754-3760, ISSN 1538-7445

Karlsson-Rosenthal, C. \& Millar, J. B. (2006). Cdc25: mechanisms of checkpoint inhibition and recovery. Trends in Cell Biology, Vol.16, No.6, (June 2006), pp. 285-292, ISSN 0962-8924

Kasaplar, P.; Çakmazer, O. Y. \& Çağir, A. (2010). Michael acepptor properties of 6bicycloaryl substituted (R)-5,6-dihydro-2H-pyran-2-ones. Bioorganic Chemistry, Vol.38, No.5, (October 2010), pp. 186-189, ISSN 0045-2068

Kasaplar, P.; Yilmazer, O. \& Çağir, A. (2009). 6-Bicycloaryl substituted (S)- and (R)-5,6dihydro-2H-pyran-2-onas : asymmetric synthesis, and anti-proliferative properties. Bioorganic \& Medicinal Chemistry, Vol.17, No.1, (October 2009), pp. 311-318, ISSN 0968-0896

Khrapunovich-Baine, M.; Menon, V.; Yang, C. P. H.; Northcote, P. T.; Miller, J. H.; Angeletti, R. H.; Fiser, A.; Horwitz, S. B. \& Xiao, H. (2011). Hallmarks of molecular action of microtubule stabilizing agents: effects of epothilone $b$, ixabepilone, peloruside a, and laulimalide on microtubule conformation. Journal of Biological Chemistry, Vol.286, No.13, (April 2011), pp. 11765-11778, ISSN 0021-9258

Kinghorn A. D.; Chin Y. W. \& Swanson S. M. (2009). Discovery of natural product anticancer agents from biodiverse organisms. Current Opinion in Drug Discovery and Development, Vol.12, No.2, (March 2009), pp. 189-196, ISNN 1367-6733

Knight, V.; Sanglier, J. J.; DiTullio, D.; Braccili, S.; Bonner, P.; Waters, J.; Hughes, D. \& Zhang, L. (2003). Diversifying microbial natural products for drug discovery. Applied Microbiology and Biotechnology, Vol.62, No.5\&6, (October 2003), pp. 446-458, ISSN 1432-0614

Kodach, L. L.; Bos, C. L.; Durán, N.; Peppelenbosch, M. P.; Ferreira, C. V. \& Hardwick, J. C. (2006). Violacein synergistically increases 5-fluorouracil cytotoxicity, induces apoptosis and inhibits Akt-mediated signal transduction in human colorectal cancer cells. Carcinogenesis, Vol.27, No.3, (March 2006), pp. 508-516, ISSN 0143-3334

Koehn, F. E. \& Carter, G. T. (2005). The evolving role of natural products in drug discovery. Nature Reviews in Drug Discovery, Vol.4, No.3, (March 2005), pp. 206-222, ISSN 1474-1784

Kunnumakkara, A. B.; Anand, P. \& Aggarwal, B. B. (2008). Curcumin inhibits proliferation, invasion, angiogenesis and metastasis of different cancers through interaction with multiple cell signaling proteins. Cancer Letters, Vol.269, No.2, (October 2008), pp. 199-225, ISSN 0304-3835

Kwon, M. J. \& Nam, T. J. (2006). Porphyran induces apoptosis related signal pathway in AGS gastric cancer cell lines. Life Sciences, Vol.79, No.20, (October 2006), pp. 19561962, ISSN 0024-3205

Kwon, M. J. \& Nam, T. J. (2007). A polysaccharide of the marine alga Capsosiphon fulvescens induces apoptosis in AGS gastric cancer cells via an IGF-IR-mediated PI3K/Akt 
pathway. Cell Biology International, Vol.31, No.8, (August 2007), pp. 768-775, ISSN 1065-6995

Laezza, C.; Fiorentino, L.; Pisanti, S.; Gazzerro, P.; Caraglia, M.; Portella, G.; Vitale, M. \& Bifulco, M. (2008). Lovastatin induces apoptosis of k-ras-transformed thyroid cells via inhibition of rasfarnesylation and by modulating redox state. Journal of Molecular Medicine, Vol.86, No.12, (December 2008), pp. 1341-1351, ISSN 1432-1440

Lam, K. S. (2007) New aspects of natural products in drug discovery. Trends in Microbiology, Vol.15, No.6, (June 2007), pp. 279-289,ISSN 0966-842X

Lee, K. H. (2004). Current developments in the discovery and design of new drugs candidates from plant natural products leads. Journal of Natural Products, Vol.67, No.2, (December 2004), pp. 273-283, ISSN 0163-3864

Leiter, J.; Downing, V.; Hartwell, J. L. \& Shear, M. J. (1950). Damage induced in sarcoma 37 with podophyllin, podophyllotoxin, alpha-peltatin, beta-peltatin and quercetin. Journal of the National Cancer Institute, Vol.10, No.6, (June 1950), pp. 1273-1293, ISSN 0027-8874

Lin, X.; Liu, M.; Hu, C. \& Liao, D. J. (2010). Targeting cellular proapoptotic molecules for developing anticancer agents from marine sources. Current Drug Targets, Vol.11, No.6, (June 2010), pp. 708-715, ISSN 1389-4501

Liu, Y. Q.; Yang, L.; Tian, X. (2007). Podophyllotoxin : current perspectives. Current Bioactive Compounds, Vol.3, No.1, (March 1997), pp. 37-66, ISSN 1573-4072

Liu, Z.; Liu, S.; Xie, Z.; Pavlovicz, R. E.; Wu, J.; Chen, P.; Aimiuwu, J.; Pang, J.; Bhasin, D.; Neviani, P.; Fuchs, J. R.; Plass, C.; Li, P. K.; Li, C.; Huang, T. H.; Wu, L. C.; Rush, L.; Wang, H.; Perrotti, D.; Marcucci, G. \& Chan K. K. (2009). Modulation of DNA methylation by a sesquiterpene lactone parthenolide. Journal of Pharmacology and Experimental Therapeutics, Vol.329, No.2, (March 2009), pp. 505-514, ISSN 0022-356

Mahfouz, M.; Hashimoto, W.; Das Gupta, T. K. \& Chakrabarty, A. M. (2007). Bacterial proteins and CpG-rich extrachromosomal DNA in potential cancer therapy. Plasmid, Vol.57, No.1, (January 2007), pp. 4-17, ISSN 1095-9890

Mann, J. (2002). Natural products in cancer chemotherapy: past, present and future. Nature Reviews Cancer, Vol.2, No.2, (February 2002), pp. 143-148, ISSN 1474-175X

Martin-Eauclaire, M. F. \& Couraud, F. (1995). Scorpion neurotoxins: effects and mechanisms, In: Handbook of Neurotoxicology, Chang, L. W., Dyer, R. S., pp. 683-716, Marcell \& Dekker, ISBN 1592591655 , New York

Mayer, A. M. \& Gustafson, K. R. (2008) Marine pharmacology in 2005-2006: antitumour and cytotoxic compounds. European Journal of Cancer, Vol.44, No.16, (November 2008), pp. 2357-2387, ISSN 0959-8049

McChesney, J. D.; Venkataraman, S. K \& Henri, J. T. (2007). Plant natural products: back to the future or into extinction? Phytochemistry, Vol.68, No.14, (July 2007), pp. 20152022, ISSN 0031-9422

Meenakshii, N.; Lee, A.; Azimahtol, H. L. P. \& Hasidah, S. (2000). Increased levels of apoptosis correlate with p53 protein accumulation in response to the styrylpyrone derivative (SPD) treatment of the 'Huggins Tumour'. Malaysian Applied Biology, Vol.29, No.1-2, pp. 121-126, ISSN 0126-8643

Melo, P. S.; Justo, G. Z.; de Azevedo, M. B.; Durán, N. \& Haun, M. (2003). Violacein and its beta-cyclodextrin complexes induce apoptosis and differentiation in HL60 cells. Toxicology, Vol.186, No.3, (April 2003), pp. 217-225, ISSN 0300-483X

Mickel, S. J.; Sedelmeier, G. H.; Niederer, D.; Daeffler, R.; Osmani, A.; Schreiner, K.; SeegerWeibel, M.; Bérod, B.; Schaer, K. \& Gamboni, R. (2004a). Large-scale synthesis of the 
anti-cancer marine natural product (+)-Discodermolide. Part 1 : synthesis strategy and preparation of a common precursor. Organic Process Research $\mathcal{E}$ Development, Vol.8, No.1, (December 2004), pp. 92-100, ISSN 1520-586X

Mickel, S. J.; Sedelmeier, G. H.; Niederer, D.; Daeffler, R.; Osmani, A.; Kuester, E.; Schaer, K. \& Gamboni, R. (2004b). Large-scale synthesis of the anti-cancer marine natural product (+)-Discodermolide. Part 5 : Linkage of fragments $C_{1-6}$ and $C_{7-24}$ and finale. Organic Process Research \& Development, Vol.8, No.1, (December 2004), pp. 122-130, ISSN 1520-586X

Mickel, S. J.; Sedelmeier, G. H.; Niederer, D.; Schuerch, F.; Grimler, D.; Koch, G.; Daeffler, R.; Osmani, A.; Hirni, A.; Schaer, K. \& Gamboni, R. (2004c). Large-scale synthesis of the anti-cancer marine natural product $(+)$-Discodermolide. Part 2: Synthesis of fragments $\mathrm{C}_{1-6}$ and $\mathrm{C}_{9-14}$. Organic Process Research \& Development, Vol.8, No.1, (December 2004), pp. 101-106, ISSN 1520-586X

Mickel, S. J.; Sedelmeier, G. H.; Niederer, D.; Schuerch, F.; Koch, G.; Kuesters, E.; Daeffler, R.; Osmani, A.; Seeger-Weibel, M.; Schimid, E.; Hirni, A.; Schaer, K. \& Gamboni, R. $(2004 \mathrm{~d})$. Large-scale synthesis of the anti-cancer marine natural product $\left(^{+}\right)$Discodermolide. Part 3: Synthesis of fragment $\mathrm{C}_{15-21}$. Organic Process Research $\mathcal{E}$ Development, Vol.8, No.1, (December 2004), pp. 107-112, ISSN 1520-586X

Mickel, S. J.; Sedelmeier, G. H.; Niederer, D.; Schuerch, F.; Seger, M.; Schreiner, K.; Daeffler, R.; Osmani, A.; Bixel, D.; Loiseleur, O.; Cercus, J.; Steller, H.; Schaer, K. \& Gamboni, R. (2004e). Large-scale synthesis of the anti-cancer marine natural product $(+)$ Discodermolide. Part 4 : Preparation of fragment $C_{7-24}$. Organic Process Research $\mathcal{E}$ Development, Vol.8, No.1, (December 2004), pp. 113-121, ISSN 1520-586X

Mizutani, H.; Hiraku, Y.; Tada-Oikawa, S.; Murata, M.; Ikemura, K.; Iwamoto, T.; Kagawa, Y.; Okuda, M. \& Kawanishi, S. (2010). Romidepsin (FK228), a potent histone deacetylase inhibitor, induces apoptosis through the generation of hydrogen peroxide. Cancer Sciences, Vol.101, No.10, (October 2010), pp. 2214-2219, ISSN 13497006

Mollinski, T.; Dalisay, D. S.; Lievens, S. L. \& Salludes, J. P. (2009). Drug development from marine natural products. Nature Reviews Drug Discovery, Vol.8, (January 2009), pp. 69-85, ISSN 1474-1776

Murakami, A.; Ashida, H. \& Terao, J. (2008). Multitargeted cancer prevention by quercetin. Cancer Letters, Vol.269, No.2, (October 2008), pp. 315-325, ISSN 0304-3835

Murphy, B. T.; Cao, S.; Brodie, P.; Maharavo, J.; Andriamanantoanina, H.; Ravelonandro, P. \& Kingston, D. G. I. (2009). Antiproliferative bistramides from Trididemnum cyclops from Madagascar (1). Journal of Natural Products, Vol.72, No.7, (July 2009), pp. 13381340, ISSN 0163-3864

Nagase, T.; Kawata, S.; Tamura, S.; Matsuda, Y.; Inui, Y.; Yamasaki, E.; Ishiguro, H.; Ito, T.; Miyagawa, J.; Mitsui, H.; Yamamoto, K.; Kinoshita, M. \& Matsuzawa, Y. (1997). Manumycin and gliotoxin derivative KT7595 block Rasfarnesylation and cell growth but do not disturb lamin farnesylation and localization in human tumour cells. British Journal of Cancer, Vol.76, No.8, (October 1997), pp. 1001-1010, ISSN 1532-1827

Nakamura, T.; Suzuki, H.; Wada, Y.; Kodama, T. \& Doi, T. (2006). Fucoidan induces nitric oxide production via p38 mitogen-activated protein kinase and NF-kB-dependent signaling pathways through macrophage scavenger receptors. Biochemical and Biophysical Research Communications, Vol.343, No.1, (April 2006), pp. 286-294, ISSN 0006-291X. 
Newman, D. J. \& Cragg, G. M. (2007). Natural products as sources of new drugs over the last 25 years. Journal of Natural Products, Vol.70, No.3, (February 2007), pp. 461-477, ISSN 1520-6025

Newman, D. J. \& Cragg, G. M. (2009). Microbial antitumor drugs: natural products of microbial origin as anticancer agents. Current Opinion in Investigational Drugs, Vol.10, No.4, (December 2009), pp. 1280-1296, ISSN 1472-4472

Newman, D. J.; Cragg, G. M. \& Snader, K. M. (2003). Natural products as sources of new drugs over the period 1981-2002. Journal of Natural Products, Vol.66, No.7, (June 2003), pp. 1022-1037, ISSN 1520-6025

Nguyen, M.; Marcellus, R. C.; Roulston, A.; Watson, M.; Serfass, L.; Murthy Madiraju, S. R.; Goulet, D.; Viallet, J.; Bélec, L.; Billot, X.; Acoca, S.; Purisima, E.; Wiegmans, A.; Cluse, L.; Johnstone, R. W.; Beauparlant, P. \& Shore, G. C. (2007). Small molecule obatoclax (GX15-070) antagonizes MCL-1 and overcomes MCL-1-mediated resistance to apoptosis. Proceedings of the National Academy of Sciences of the United States of America, Vol.104, No.49, (December 2007), pp. 19512-19517, ISSN 0027-8424

Nicolaou, K. C. \& Snyder, S. A. (Eds.). (2003). Classics in Total Synthesis II: More Targets, Strategies, Methods, John Wiley \& Sons, ISBN 978-3-527-30684-8, Germany

Nicolaou, K. C. \& Sorensen, E. J. (Eds.). (1996). Classics in Total Synthesis: Targets, Strategies, Methods, Wiley-VCH, ISBN 978-3-527-29231-8, Germany

Nobili, S.; Landini, I.; Mazzei, T. \& Mini, E. (2011). Overcoming tumor multidrug resistance using drugs able to evade P-glycoprotein or to exploit its expression. Medical Research Reviews, in press, doi: 10.1002/med.20239, (March 2011), ISSN 1098-1128

Numata, A.; Iritani, M.; Yamada, T.; Minoura, K.; Matsumura, E.; Yamori, T. \& Tsuruo, T. (1997). Novel antitumor metabolites produced by a fungal strain from a sea hare. Tetrahedron Letters, Vol.38, No.47, (December 1997), pp. 8215-8218, ISSN 0040-4039

Ori, M. \& Ikeda, H. (1998). Spider venoms and spider toxins. Journal of Toxicolology, Vol. 17, No.3, pp. 405-426, ISSN 1687-8191

Ownby, C. L.; Powell, J. R.; Jiang, M. S. \& Fletcher, J. E. (1997). Melittin and phospholipase A2 from bee (Apis mellifera) venom cause necrosis of murine skeletal muscle in vivo. Toxicon, Vol. 35, No.1, (January 1997), pp. 67-80, ISSN 0041-0101

Paleari, L.; Trombino, S.; Falugi, C.; Gallus, L.; Carlone, S.; Angelini, C.; Sepcic, K.; Turk, T.; Faimali, M.; Noonan, D. M. \& Albini, A. (2006). Marine sponge-derived polymeric alkylpyridinium salts as a novel tumor chemotherapeutic targeting the cholinergic system in lung tumors. International Journal of Oncology, Vol.29, No.6, (December 2006), pp. 1381-1388, ISSN 1019-6439

Panicker, J.; Li, Z.; McMahon, C.; Sizer, C.; Steadman, K.; Piekarz, R.; Bates, S. E. \& Thiele, C. J. (2010). Romidepsin (FK228/depsipeptide) controls growth and induces apoptosis in neuroblastoma tumor cells. Cell Cycle, Vol.9, No.9, (May 2010), pp. 1830-1838, ISSN 1551-4005

Pettit, R. K. (2009). Mixed fermentation for natural product drug discovery. Applied Microbiology and Biotechnology, Vol.83, No.1, (May 2009), pp. 19-25, ISSN 1432-0614

Pfeiffer, D. R.; Gudz, T. I.; Novgorodov, S. A. \& Erdahl, W. L. (1995). The peptide mastoparan is a potent facilitator of the mitochondrial permeability transition. Journal of Biological Chemistry, Vol.270, No.9, (March 1995), pp. 4923-4932, ISSN 1083-351X

Piekarz, R. L.; Frye, R.; Turner, M.; Wright, J. J.; Allen, S.L.; Kirschbaum, M. H.; Zain, J.; Prince, H. M.; Leonard, J. P.; Geskin, L. J.; Reeder, C.; Joske, D.; Figg, W. D.; Gardner, E. R.; Steinberg, S. M.; Jaffe, E. S.; Stetler-Stevenson, M.; Lade, S.; Fojo, A. 
T. \& Bates, S. E. (2009). Phase II multi-institutional trial of the histone deacetylase inhibitor romidepsin as monotherapy for patients with cutaneous T-cell lymphoma. Journal Clinical Oncology, Vol.27, No.32, (November 2009), pp. 5410-5417, ISSN 15277755

Pihie, A. H. L.; Stanslas, J. \& Bin, D. L. (1998). Non-steroid receptor-mediated antiproliferative activity of styrylpyrone derivative in human breast cancer cell lines. Anticancer Research, Vol.18, No.3A, (May-June 1998), pp. 1739-1743, ISSN 0250-7005

Pinto, A. F. M.; Silva, K. R. L. M. \& Guimarães, J. A. (2006). Proteases from Lonomia obliqua venomous secretions: comparison of procoagulant fibrinogenolytic and amidolytic activities. Toxicon, Vol.47, No.1, (January 2006), pp.113-121, ISSN 0041-0101

Podwyssotzki, V. (1881). The active constituents of podophyllin. Pharmaceutical Journal and Transactions, Vol.12, pp. 217-218, ISSN n.d.

Podwyssotzki, V. (1882). On the active constituents of podophyllin. American Journal of Pharmaceuticals, Vol.12, pp. 102-115, ISSN n.d.

Possani, L. D.; Beceril, B.; Tytgat, J. \& Delepierre, M. (2001). High affinity scorpion toxins for studying potassium and sodium channels, In: Ion Channel Localization Methods and Protocols, A. Lopatin ; C.G. Nichols (Eds.), 145-165, Humana Press Inc., ISBN 978-089603-833-2 , Totowa, New Jersey

Pryor, D. E.; O'Brate, A.; Bilcer, G.; Diaz, J. F.; Wang, Y.; Wang, Y.; Kabaki, M.; Jung, M. K.; Andreu, J. M.; Ghosh, A. K.; Giannakakou, P. \& Hamel, E. (2002). The microtubule stabilizing agent laulimalide does not bind in the taxoid site, kills cells resistant to paclitaxel and epothilones, and may not require its epoxide moiety for activity. Biochemistry, Vol.41, No.29, (June 2002), pp. 9109-9115, ISSN 0006-2960

Queiroz, A. F.; Silva, R. A.; Moura, R. M.; Dreyfuss, J. L.; Paredes-Gamero, E. J.; Souza, A. C.; Tersariol, I. L.; Santos, E. A.; Nader, H. B.; Justo, G. Z. \& de Sales, M. P. (2009). Growth inhibitory activity of a novel lectin from Cliona varians against K562 human erythroleukemia cells. Cancer Chemotherapy and Pharmacology, Vol.63, No.6, (May 2009), pp. 1023-1033, ISSN 0344-5704

Rash, L. D. \& Hodgson, W. C. (2002). Pharmacology and biochemistry of spider venoms. Toxicon, Vol.40, No.3, (March 2002), pp. 225-254, ISSN 0041-0101

Ravelo, A. G.; Estevez-Braun, A.; Chavez-Orellana, H.; Perez-Sacau, E. \& Mesa-Siverio, D., (2004). Recent studies on natural products as anticancer agents. Current Topics in Medicinal Chemistry, Vol.4, No.2, pp. 241-265, ISSN 1568-0266

Ravindran, J.; Prasad, S. \& Aggarwal, B. B. (2009). Curcumin and cancer cells: how many ways can curry kill tumor cells selectively? American Association of Pharmaceutical Scientists Journal, Vol.11, No.3, (September 2009), pp. 495-510, ISSN 1550-7416

Rizvi, S. A.; Liu, S.; Chen, Z.; Skau, C.; Pytynia, M.; Kovar, D. R.; Chmura, S. J. \& Kozmin, S. A. (2010). Rationally simplified bistramide analog reversibly targets actin polymerization and inhibits cancer progression in vitro and in vivo. Journal of the American Chemical Society, Vol.132, No.21, (June 2010), pp. 7288-7290, ISSN 00027863

Rocha, H. A. O.; Franco, C. R. C.; Trindade, E. S.; Veiga, S. S.; Leite, E. L.; Nader, H. B. \& Dietrich, C. P. (2005). Fucan inhibits Chinese hamster ovary cell (CHO) adhesion to fibronectin by binding to the extracellular matrix. Planta Medica, Vol.71, No.7 (July 2005), pp. 628-633, ISSN 0032-0943

Rodrigues, E. G.; Dobroff, A. S.; Cavarsan, C. F.; Paschoalin, T.; Nimrichter, L.; Mortara, R. A.; Santos, E. L.; Fázio, M. A.; Miranda, A.; Daffre, S. \& Travassos, L. R. (2008). 
Effective topical treatment of subcutaneous murine B16F10-Nex2 melanoma by the antimicrobial peptide gomesin. Neoplasia, Vol.10, No.1, (January 2008), pp. 61-68, ISSN 1476-5586

Rudy, A.; López-Antón, N.; Dirsch, V. M. \& Vollmar, A. M. (2008). The cephalostatin way of apoptosis. Journal of Natural Products, Vol.71, No.3, (March 2008), pp. 482-486, ISSN 0163-3864

Sánchez, A. M.; Malagarie-Cazenave, S.; Olea, N.; Vara, D.; Cuevas, C. \& Díaz-Laviada, I. (2008). Spisulosine (ES-285) induces prostate tumor PC-3 and LNCaP cell death by de novo synthesis of ceramide and PKC $\zeta$ activation. European Journal of Pharmacology, Vol.584, No.2-3, (April 2008), pp. 237-245, ISSN 0014-2999

Sanz, M. A. \& Lo-Coco, F. (2011). Modern approaches to treating acute promyelocytic leukemia. Journal of Clinical Oncology, Vol.29, No.5, (February 2011), pp. 495-503, ISSN 0732-183X

Schacter, L. P.; Igwemezie, L. N.; Seyedsadr, M.; Morgenthien, E.; Randolph, J.; Albert, E. \& Santabárbara, P. (1994). Clinical and pharmacokinetic over view of parenteral etoposide phosphate. Cancer Chemotherapy and Pharmacology, Vol.34, Suppl.1, (December 1994), pp. S58-S63, ISSN 0344-5704

Schmidt, B. M.; Ribnicky, D. M.; Lipsky, P. E. \& Raskin, I. (2007). Revisiting the ancient concept of botanical therapeutics. Nature Chemical Biology, Vol.3, No.7, (July 2007), pp. 360-366, ISSN 1552-4450

Schrump, D. S.; Fischette, M. R.; Nguyen, D. M.; Zhao, M.; Li, X.; Kunst, T. F.; Hancox, A.; Hong, J. A.; Chen, G. A.; Kruchin, E.; Wright, J. J.; Rosing, D. R.; Sparreboom, A.; Figg, W. D. \& Steinberg, S. M. (2008). Clinical and molecular responses in lung cancer patients receiving Romidepsin. Clinical Cancer Research, Vol.14, No.1, (January 2008), pp. 188-198, ISSN 1557-3265

Shaposhnikova, V. V.; Egorova, M. V.; Kudryavtsev, A. A.; Levitman, M. K. H. \& Korystov, Y. N. (1997). The effect of melittin on proliferation and death of thymocytes. FEBS Letters, Vol.410, No.2-3, (June 1997), pp. 285-288, ISSN 0014-5793

Shindoh, N.; Mori, M.; Terada, Y.; Oda, K.; Amino, N.; Kita, A.; Taniguchi, M.; Sohda, K. Y.; Nagai, K.; Sowa, Y.; Masuoka, Y.; Orita, M.; Sasamata, M.; Matsushime, H.; Furuichi, K. \& Sakai, T. (2008). YM753, a novel histone deacetylase inhibitor, exhibits antitumor activity with selective, sustained accumulation of acetylated histones in tumors in the WiDr xenograft model. International Journal of Oncology, Vol.32, No.3, (March 2008), pp. 545-555, ISSN 1791-2423

Silva, P. H.; da Silveira, R. B.; Appel, M. H.; Mangili, O. C.; Gremski, W. \& Veiga, S. S. (2004). Brown spiders and loxoscelism. Toxicon, Vol.44, No.7, (December 2004), pp. 693709, ISSN 0041-0101

Simmons, T. L.; Andrianasolo, E.; McPhail, K.; Flatt, P. \& Gerwick W. H. (2005). Marine natural products as anticancer drugs. Molecular Cancer Therapeutics, Vol.4, No.2, (February 2005), pp. 333-342, ISSN 1535-7163

Singh, B. K. \& Macdonald, C. A. (2010). Drug discovery from uncultivable microorganisms. Drug Discovery Today, Vol.15, No.17-18, (September 2010), pp. 792-799, ISSN 13596446

Son, D. J.; Park, M. H.; Chae, S. J.; Moon, S. O.; Lee, J. W.; Song, H. S.; Moon, D. C.; Kang, S. S.; Kwon, Y. E. \& Hong, J. T. (2007). Inhibitory effect of snake venom toxin from Vipera lebetina turanica on hormonerefractory human prostate cancer cell growth: induction of apoptosis through inactivation of NFkB. Molecular Cancer Therapeutics, Vol. 6, No.2, (February 2007), pp. 675-683, ISSN 1538-8514 
Sonoda, Y.; Hada, N.; Kaneda, T.; Suzuki, T.; Ohshio, T.; Takeda, T. \& Kasahara, T. (2008). A synthetic glycosphingolipid-induced antiproliferative effect in melanoma cells is associated with suppression of FAK, Akt, and Erk activation. Biological $\mathcal{E}$ Pharmaceutical Bulletin, Vol. 31, No.6, (June 2008), pp. 1279-1283, ISSN 1347-5215

Souza, A. P.; Peixoto, C. C.; Maranga, L.; Carvalhal, A. V.; Moraes, R. H.; Mendonça, R. M.; Pereira, C. A.; Carrondo, M. J. \& Mendonça, R. Z. (2005). Purification and characterization of an anti-apoptotic protein isolated from Lonomia obliqua hemolymph. Biotechnology Progress, Vol.21, No.1, (January-February 2005), pp.99105, ISSN 8756-7938

Stähelin, H. F. \& von Wartburg, A. (1991). The chemical and biological route from podophyllotoxin glucoside to etoposide : ninth cain memorial award lecture. Cancer Research, Vol.51, No.1, (January 1991), pp. 5-15,

Subrahmanyam, D.; Renuka, B.; Rao, C. V.; Sagar, P. S.; Deevi, D. S.; Babu, J. M. \& Vyas, K. (1998). Novel D-Ring analogues of podophyllotoxin as potent anti-cancer agents. Bioorganic \& Medicinal Chemistry, Vol.8, No.11, (June 1998), pp. 1391-1396, ISSN 0960-894X

Sumikura, H.; Andersen, O. K.; Drewes, A. M. \& Arendt-Nielsen, L. (2003). A comparison of hyperalgesia and neurogenic inflammation induced by melittin and capsaicin in humans. Neuroscience Letters, Vol.337, No.3, (February 2003), pp. 147-150, ISSN 0304-3940

Suttmann, H.; Retz, M.; Paulsen, F.; Harder, J.; Zwergel, U.; Kamradt, J.; Wullich, B.; Unteregger, G.; Stöckle, M. \& Lehmann, J. (2008). Antimicrobial peptides of the Cecropin-family show potent antitumor activity against bladder cancer cells. BMC Urology, Vol.8, (March 2008), pp. 5, ISSN 1471-2490

Swenson, S.; Ramu, S. \& Markland, F. S. (2007). Anti-angiogenesis and RGD-containing snake venom disintegrins. Current Pharmaceutical Design, Vol.13, No.28, pp. 28602871, ISSN 1381-6128

Tan, G.; Gyllenhaal, C. \& Soejarto, D. D. (2006). Biodiversity as a source of anticancer drugs. Current Drug Targets, Vol.7, No.3, (March 2006), pp. 265-277, ISSN 1389-4501

Taniguchi, M.; Nunnery, J. K.; Engene, N.; Esquenazi, E.; Byrum, T.; Dorrestein, P. C. \& Gerwick, W. H. (2010). Palmyramide A, a cyclic depsipeptide from a Palmyra Atoll collection of the marine cyanobacterium Lyngbya majuscula. Journal of Natural Products, Vol.73, No.3 (March 2010), pp. 393-398, ISSN 0163-3864

Trump, D. L.; Muindi, J.; Fakih, M.; Yu, W. D. \& Johnson, C. S. (2006). Vitamin D compounds: clinical development as cancer therapy and prevention agents. Anticancer Research, Vol.26, No.4A, (July-August 2006), pp. 2551-2556, ISSN 02507005

Ueda, H.; Manda, T.; Matsumoto, S.; Mukumoto, S.; Nishigaki, F.; Kawamura, I. \& Shimomura, K. (1994). FR901228, a novel antitumor bicyclic depsipeptide produced by Chromobacterium violaceum No. 968. III. Antitumor activities on experimental tumors in mice. The Journal of Antibiotics (Tokyo), Vol.43, No.3, (March 1994), pp. 315-323, ISSN 0021-8820

Usami, Y.; Ohsugi, M.; Mizuki, K.; Ichikawa, H. \& Arimoto, M. (2009). Facile and efficient synthesis of naturally occurring carbasugars (+)-pericosines A and C. Organic Letters, Vol.11, No.12, (June 2009), pp. 2699-2701, ISSN 1523-7052

Utsugi, T.; Shibata, J.; Sugimoto, Y.; Aoyagi, K.; Wierzba, K.; Kobunai, T.; Terada, T.; Ohhara, T.; Tsuruo, T. \& Yamada, Y. (1996). Antitumor activity of a novel 
podophyllotoxin derivative (TOP-53) against lung cancer and lung metastatic cancer. Cancer Research, Vol.56, No.12, (June 1996), pp. 2809-2814, ISSN 1538-7445

Veiga, A. B.; Pinto, A F. \& Guimarães, J. A. (2003). Fibrinogenolytic and procoagulant activities in the hemorrhagic syndrome caused by Lonomia obliqua caterpillars. Thrombosis Research, Vol.111, No.1-2, pp. 95-101, ISSN 0049-3848

Veiseh, M.; Gabikian, P.; Bahrami, S. B.; Veiseh, O.; Zhang, M.; Hackman, R. C.; Ravanpay, A. C.; Stroud, M. R.; Kusuma, Y.; Hansen, S. J.; Kwok, D.; Munoz, N. M.; Sze, R. W.; Grady, W. M.; Greenberg, N. M.; Ellenbogen, R. G. \& Olson, J. M. (2007). Tumor paint: a chlorotoxin: Cy5.5 bioconjugate for intraoperative visualization of cancer foci. Cancer Research, Vol.67, No.14, (July 2007), pp. 6882-6888, ISSN 1538-7445

Vendramini-Costa, D. B., de Castro, I. B. D., Ruiz, A. L. T. G., Marquissolo, C., Pilli, R. A. \& de Carvalho, J. E. (2010). Effect of goniothalamin on the development of Ehrlich solid tumor in mice. Bioorganic \& Medicinal Chemistry, Vol.18, No.18, (September 2010), pp. 6742-6747, ISSN 0960-894X

Vigil, D.; Cherfils, J.; Rossman, K. L. \& Der, C. J. (2010). Ras superfamily GEFs and GAPs: validated and tractable targets for cancer therapy? Nature Reviews Cancer, Vol.10, No.12, (December 2010), pp. 842-857, ISSN 1474-175X

Vilella, D.; Sánchez, M.; Platas, G.; Salazar, O.; Genilloud, O.; Royo, I.; Cascales, C.; Martín, I.; Díez, T.; Silverman, K. C.; Lingham, R. B.; Singh, S. B.; Jayasuriya, H. \& Peláez, F. (2000). Inhibitors of farnesylation of Ras from a microbial natural products screening program. Journal of Industrial Microbiology and Biotechnology, Vol.25, No.6, (December 2000), pp. 315-327, ISSN 1476-5535

Vuorelaa, P.; Leinonenb, M.; Saikkuc, P.; Tammelaa, P.; Rauhad, J. P.; Wennberge, T. \& Vuorela H. (2004). Natural products in the process of finding new drug candidates. Current Medicinal Chemistry, Vol.11, No.11, (June 2004), pp. 1375-1389, ISSN 09298673

Wach, J. Y.; Güttinger, S.; Kutay, U. \& Gademann K. (2010). The cytotoxic styryl lactone goniothalamin is an inhibitor of nucleocytoplasmic transport. Bioorganic $\mathcal{E}$ Medicinal Chemistry Letters, Vol.20, No.9, (March 2010), pp. 2843-2846, ISSN 0960$894 X$

Wade, D.; Boman, A.; Wåhlin, B.; Drain, C. M.; Andreu, D.; Boman, H. G. \& Merrifield, R. B. (1990). All-D amino acid-containing channel forming antibiotic peptides. Proceedings of the National Academy of Sciences of the United States of America, Vol.87, No.12, (June 1990), pp. 4761-4765, ISSN 1091-6490

Walenkamp, A. M. E.; Boer, I. G.; Bestebroer, J.; Rozeveld, D.; Timmer-Bosscha, H.; Hemrika, W.; van Strijp, J. A. \& de Haas, C. J. (2009). Staphylococcal superantigenlike 10 inhibits CXCL12-induced human tumor cell migration. Neoplasia, Vol.11, No.4, (April 2009), pp. 333-344, ISSN 1476-5586

Walenkamp, A. M. E. (2010). Bacterial proteins against metastasis, In: Emerging Cancer Therapy: Microbial approaches and Biotechnological Tools, Fialho A. M., Chakrabarty A. M., John Wiley \& Sons, Retrieved from http:// onlinelibrary.wiley.com/doi/10.1002/9780470626528.ch11/summary

Winther, A. M.; Liu, H.; Sonntag, Y.; Olesen, C.; le Maire, M.; Soehoel, H.; Olsen, C. E.; Christensen, S. B.; Nissen, P. \& Møller, J. V. (2010). Critical roles of hydrophobicity and orientation of side chains for inactivation of sarcoplasmic reticulum $\mathrm{Ca} 2+-$ ATPase with thapsigargin and thapsigargin analogs. Journal of Biological Chemistry, Vol.285, No.37, (September 2010), pp. 28883-28892, ISSN 0021-9258 
Wolf, P. \& Elsasser-Beile, U. (2009). Pseudomonas Exotoxin A based immunotoxins for targeted cancer therapy, In: Emerging Cancer Therapy: Microbial approaches and Biotechnological Tools, Fialho A. M., Chakrabarty A. M., John Wiley \& Sons, Retrieved from http:// onlinelibrary.wiley.com/doi/10.1002/9780470626528.ch12/summary

$\mathrm{Xu}, \mathrm{C}$; Zhao, Y. \& Zhao, B. (2010). The interaction of azurin and C-terminal domain of p53 is mediated by nucleic acids. Archives of Biochemistry and Biophysics, Vol.503, No.2, (November 2010), pp. 223-229, ISSN 0003-9861

Yamada, T.; Iritani, M.; Ohishi, H.; Tanaka, K.; Minoura, K.; Doi, M. \& Numata, A. (2007). Pericosines, antitumour metabolites from the sea hare-derived fungus Periconiabyssoides. Structures and biological activities. Organic and Biomolecular Chemistry, Vol.5, No.24, (December 2007), pp. 3979-3986, ISSN1477-0539

Yamada, Y.; Shinohara, Y.; Kakudo, T.; Chaki, S.; Futaki, S.; Kamiya, H. \& Harashima, H. (2005). Mitochondrial delivery of mastoparan with transferring liposomes equipped with a $\mathrm{pH}$-sensitive fusogenic peptide for selective cancer therapy. International Journal of Pharmaceutics, Vol.303, No.1-2, (October 2005), pp. 1-7, ISSN 0378-5173

Yeh, J. Y.; Huang, W. J.; Kan, S. F. \& Wang, P. S. (2003). Effects of bufalin and cinobufagin on the proliferation of androgen dependent and independent prostate cancer cells, Prostate, Vol.54, No.2, (February 2003), pp. 112, ISSN 1097-0045

Yu, H.; Yang, H.; Ma, D.; Lv, Y.; Liu, T.; Zhang, K.; Lai, R. \& Liu, J. (2007). Vespid chemotactic peptide precursor from the wasp, Vespa magnifica (Smith). Toxicon, Vol.50, No.3, (September 2007), pp. 377-382, ISSN 0041-0101

Zhao, S.; Du, X. Y.; Chai, M. Q.; Chen, J. S.; Zhou, Y. C. \& Song, J. G. (2002). Secretory phospholipase A2 induces apoptosis via a mechanism involving ceramide generation. Biochimica et Biophysica Acta, Vol.1581, No.3, (April 2002), pp. 75-88, ISSN 0006-3002

Zhou, G.; Sun, Y.; Xin, H.; Zhang, Y.; Li, Z. \& Xu, Z. (2004). In vivo antitumor and immunomodulation activities of different molecular weight lambda-carrageenans from Chondrus ocellatus. Pharmacological Research, Vol.50, No.1, (July 2004), pp. 4753, ISSN 1043-6618

Zhou, F. S.; Tang, W. D.; Mu, Q.; Yang, G. X.; Wang, Y.; Liang, G. L. \& Lou, L. G. (2005). Semisynthesis and antitumor activities of new styryl-lactone derivatives. Chemical E Pharmaceutical Bulletin, Vol.53, No.11, (June 2005), pp. 1387-1391, ISSN 1347-5223 



\section{Edited by Oscar Grillo and Gianfranco Venora}

Biological Diversity and Sustainable Resources Use is a very interesting volume, including attractive overviews and original case studies mainly focused on socio-economical effects of the right management of the ecosystems biodiversity, as well as on the useful integration between human activities and environmental responses. Ecological, medical and historical aspects of the sustainable development are also discussed in this book which consists of articles written by international experts, offering the reader a clear and extensive view of the present condition in which our planet is. 